\title{
Fatores associados à fluorose dentária em área com água fluoretada
}

\section{Tania Izabel Bighetti Forni}

Tese apresentada ao Programa de PósGraduação em Saúde Pública para obtenção do título de Doutor em Saúde Pública.

Área de concentração: Serviços de Saúde Pública

Orientador: Prof. Dr. Paulo Frazão

São Paulo 2005 
A sabedoria não nos é dada. É preciso descobri-la por nós mesmos, depois de uma viagem que ninguém pode nos poupar ou fazer por nós.

A verdadeira viagem de descobrimento não consiste em procurar novas paisagens, mas em ter novos olhos. 
Aos meus pais, pelo amor incondicional e pelas preocupações constantes,

a Rosana, Guilherme, Guigo e Gabriela pelo apoio nos momentos mais difíceis

e ao Mario pelas emoções vividas, pelos valores revistos... 


\section{AGRADECIMENTOS}

Ao Prof. Dr. Paulo Frazão, pelo privilégio de ter a sua orientação, pelo exemplo de ética e profissionalismo, pelo apoio e amizade, pela confiança depositada e pelo suporte permanente durante o desenvolvimento desta pesquisa.

À Profạ. Dra. Maria do Rosário Dias pelo carinho e atenção, pelas concessões em sua agenda, pelo auxílio na organização dos dados e análise estatística e pelas contribuições na fase de pré-banca.

Ao Prof. Dr. Paulo Capel Narvai pela disponibilidade, pelo auxílio na construção do esquema de escolha de quantidade de dentifrício e pelas contribuições na fase de prébanca.

Ao Prof. Jaime Aparecido Cury pela atenção dispensada sempre que solicitado, pelas sugestões de referências bibliográficas e pelas contribuições durante a fase de pré-banca.

Profạ. Dra. Maria da Luz Rosário de Sousa, pela amizade e pelas contribuições durante a fase de pré-banca.

Ao Prof. Dr. Roberto Augusto Castellanos, pelo carinho e pelas contribuições na fase de pré-banca.

À Secretaria Municipal de Saúde de Ribeirão Pires, nas pessoas dos secretários de saúde Ronaldo Queródia, Ricardo Carajeleascow e Carlos Magno Sila, e da gerente de saúde Neide da Penha Teles, pela viabilização do desenvolvimento da pesquisa.

Ao Coordenador de Saúde Bucal do Município de Ribeirão Pires, Anderson Gomes Mota, presente e atuante durante todo o desenvolvimento da pesquisa.

À enfermeira Ana Maria C. Silva responsável pelo Programa de Agentes Comunitários de Saúde do Município de Ribeirão Pires pela mobilização e estímulo à participação dos agentes comunitários de saúde e pelo apoio em momentos decisivos.

À cirurgiã-dentista da Secretaria Municipal de Saúde de Ribeirão Pires Leslie Roberta da Costa pela dedicação na identificação de casos e controles.

Aos agentes comunitários de saúde Aláide Dias Borges Alves de Souza, Alexandra de Lima Silva, Andréia R. C. Moreira, Ana Maria Souza de Oliveira, Ana Maria de S. Oliveira, André Wilson Nicolau, Antonio da Silva Carlos, Carla Janaína Pereira, Cláudio Gomes da Silva, Cristiane Aparecida de Souza, Dirce Assunção Zeferino, Edna de Freitas, Edson Ferreira Lopes, Eliana Márcia de Oliveira, Elisângela Beserra dos Santos, Elizabete Bonfim dos Santos Oliveira, Elza de Oliveira Alves, Flávia Dias Paixão, Flávia Gomes Quintal, Fernanda da Silva Mariano, Francisca das Chagas Santos, Francisca Vieira da Silva, Giselda Fabiana Braga, Herlane Alves Ferreira, Liliane Aparecida dos Santos, Leni Souza de O. Mortágua, Luciene Ribeiro Soares, Ludmila Pinheiro de Aguiar, Luciene Cristina Bartolo, Maria Anastácia Luz, Maria Angélica Barreto, Maria Aparecida da Silva Gonçalves, Maria Aparecida Pereira, Maria Aparecida Souza Torres, Maria de Fátima Beltrandt Cunha, Maria Eugênia Saturno de Souza, Maria Marleide P. Duarte, Maria Rejane de Araújo, Marinaldo Vicente, Mariza Cesário da Silva, Nilson Rodrigues, Otaviana Maria de Jesus Araújo Feitosa, Pedro Gustavo Moraes, Raquel Isolina Nogueira, Regina Celia Souza Piza, Sandra Regina da Silva, Sandra Regina de Paula, Sara Alves dos Santos, Vergínia do Espírito Santo, Vera Alves Silva, Walkíria Helena Vicente, Willians Soares, Wilma Aparecida Lopes Muniz e aos membros da equipe de saúde bucal da Secretaria Municipal de Saúde de 
Ribeirão Pires Adriana Cristina Neri, Adriana Scudero Gomes, Ângela Maria de Souza Vieira e Teresa Martins Garcia Cordeiro, pelo empenho na condução das entrevistas.

À Prof ${ }^{\text {. }}$. Dra. Maria Cristina Marino Calvo, pela amizade e pelo auxílio em informática.

Ao Prof. Dr. Sérgio Fernando Torres de Freitas pelo empréstimo de material bibliográfico.

Ao Prof. Dr. Carlos Augusto Pavanelli pelo auxílio em informática na construção da figura com o mapa do Município de Ribeirão Pires.

À cirurgiã-dentista Cinthia Sampaio Cristo pelo desenvolvimento da revisão de literatura sobre flúor em peixes.

Ao Prof. Dr. Daniel Korytnick e ao meu primo José Ricardo Bigueti pelo auxílio no idioma inglês.

Ao Prof. José Leopoldo Ferreira Antunes pelo auxílio em informática.

Ao digitador Fábio Martins Costa pelo empenho no trabalho efetuado.

Ao amigo Reginaldo Francisco Lopes pelo auxílio na transcrição das fichas de digitação.

À Sra. Erna Liblik Kusberg pela revisão do Dicionário de Especialidades Farmacêuticas e identificação de medicamentos com flúor em sua composição.

À Dra. Maria da Candelária Soares, pelas oportunidades proporcionadas na Área Técnica de Saúde Bucal da Secretaria de Estado da Saúde, pela compreensão e carinho.

Ao amigo Vladen Vieira, pelo auxílio na confecção da ficha de digitação.

Aos amigos da Área Técnica de Saúde Bucal da Secretaria de Estado da Saúde: Ana Flávia Pagliusi, Ângela Spadari D'Amelio, Doralice Severo da Cruz, Francisco Ferreira de Souza, Julie Silvia Martins e Maria Egláucia Brandão pelo carinho.

À Prof ${ }^{a}$. Regina A. de Amorim Marques, à Prof ${ }^{a}$ Katia Cristina G. E. Andrade, ao Prof. Douglas A. Schneider Filho pelo incentivo e apoio.

Ao Prof. Antonio Carlos Frias e à amiga Tatiana Mello pelo auxílio durante o curso das disciplinas de Análise Estatística (Análise de Regressão).

À Prof. Dra. Patrícia Constante Jaime pelo empréstimo de material bibliográfico e orientações.

À cirurgiã-dentista Carla Campion Carrinho pela elaboração do protocolo de tratamento.

À minha secretária Adriana Martins da Silva, pela colaboração durante o monitoramento das entrevistas.

Aos amigos Sandra Regina Ribeiro Martin e Nilton César Gennari pelo carinho e dedicação.

Aos participantes da pesquisa, sem os quais seria impossível realizá-la. 


\section{RESUMO}

Forni TIB. Fatores associados à fluorose dentária em área com água fluoretada. São Paulo; 2005 [Tese de Doutorado - Faculdade de Saúde Pública - USP]

O objetivo do estudo foi identificar fatores associados à fluorose dentária em Ribeirão Pires-SP, com água fluoretada desde 1985 e heterocontrole dos teores de flúor desde 1996. Foi realizada pesquisa epidemiológica tipo casocontrole com projeto aprovado pelo Comitê de Ética da FSP-USP. A população de estudo foi adolescentes de 12 a 15 anos de idade, identificados em 23 escolas de ensino fundamental por cirurgiã-dentista capacitada $(\mathrm{k}=0,79)$. Foram considerados casos 667 adolescentes com graus de fluorose 2, 3, 4 e 5 (Índice de Dean). A partir da região de residência dos casos, foram identificados 416 controles, de mesmo sexo e idade, com grau de fluorose 0 , procurando-se garantir a mesma distribuição por região. Casos e controles (5\%) foram examinados pela pesquisadora $(\mathrm{k}=0,90)$. Um formulário de entrevista foi construído, utilizando-se técnica de pesquisa exploratória, contendo dados relativos a variáveis demográficas, geográficas, escolaridade dos pais/responsáveis e relacionados à exposição a fontes de flúor em três ciclos (1ํano de vida, 1 a 3 anos e 4 a 6 anos de idade). A coleta dos dados foi feita por 55 entrevistadores cujo treinamento contemplou repetição de entrevistas e discussão de aspectos relevantes. Foram realizadas 509 entrevistas (319 casos e 190 controles). As respostas foram transcritas para digitação de forma dupla, com validação do banco de dados. A distribuição percentual do evento nos casos e controles nas categorias de exposição foi analisada utilizando-se o teste de Qui-quadrado de Pearson. $\mathrm{Na}$ análise univariada identificou-se as de maior associação para elaboração de modelos de regressão logística múltipla não condicional. A análise mostrou risco significativo para fluorose dentária nas seguintes situações de exposição: quando os adolescentes usaram dentifrício fluoretado nos 6 primeiros anos de vida $(O R=2,25 ; p=0,048)$ e eram responsáveis pela sua colocação no período de 4 a 6 anos de idade $(\mathrm{OR}=2,17 ; \mathrm{p}=0,000)$, quando foi utilizada água fluoretada para preparo de alimentos nos 6 primeiros anos de vida $(\mathrm{OR}=2,90 ; \mathrm{p}=0,026)$ e a interação entre maior escolaridade do pai e menor escolaridade da mãe $(O R=2,15$; $\mathrm{p}=0,024)$. Recomenda-se que os serviços de saúde considerem os resultados no planejamento das ações de educação em saúde reforçando o uso adequado de dentifrícios, além de manter a política de vigilância sanitária dirigida a múltiplas fontes de flúor.

Descritores: Fluorose Dentária. Flúor. Epidemiologia. Risco. 


\section{SUMMARY}

Forni, TIB. Factors associated with dental fluorosis in a water fluoridated area. São Paulo; 2005 [Tese de Doutorado - Faculdade de Saúde Pública - USP]

The purpose of this study was to identify factors associated with fluorosis in the city of Ribeirão Pires - SP, which has fluoridated water since 1985, (with hetero-controls of fluoride levels since 1996). It was done an epidemiological case-control study which project was approved by the Ethics Committee of the FSP-USP. The study population consisted of 12 to 15 year old teenagers, identified by a trained dentist $(\mathrm{k}=0.79)$ in 23 high schools. 667 teenagers who showed fluorosis levels of 2, 3, 4 or 5 (Dean Index) were selected for this study. 416 children of the same age and sex and living in the same area were also identified as controls (fluorosis level $=0$ ) in order to assure the same distribution by region. Cases and controls (5\%) were examined $(\mathrm{k}=0.90)$ by the author. A questionnaire was elaborated, using the exploratory survey method, with data related to demographic, geographic, education level of parents/guardians, related to fluoride sources exposure in 3 different periods of life (first year, 1 to 3 years and 4 to 6 years of age). Data was collected by 55 interviewers whose training consisted of repeated interviews and case discussions. 509 interviews were made (319 cases and 190 controls) and the responses were transcribed and typed twice, with posterior validation of the database. Percentile distribution of the events of cases and controls of exposition categories were analyzed using Pearson Chi-Square test. In the univariable analysis, the variables with higher match were identified for posterior construction of models of non-conditional multiple logistic regression analyses. The analysis of regression showed significant risk for dental fluorosis in the following exposure situations: when the teenagers used fluoridated dentifrice during the first 6 years of life $(O R=2.25$; $\mathrm{p}=0.048$ ) and they were responsible for its placement in a period of 4 to 6 years $(\mathrm{OR}=2.17 ; \mathrm{p}=0.000)$, when it was used fluoridated water for food preparation during the 6 first years of life $(\mathrm{OR}=2.90 ; \mathrm{p}=0.026)$ and in the relation of high educational level of the father and lower educational level of the mother $(\mathrm{OR}=2.15 ; \mathrm{p}=0.024)$. It is recommended that the health services should consider these results in the planning of actions of health education activities in order to emphasize the importance of adequate use of dentifrices, and to maintain their sanitary control policies focused on multiple sources of fluoride.

Key words: Dental fluorosis, Fluoride, Epidemiology, Risk. 


\section{ÍNDICE}

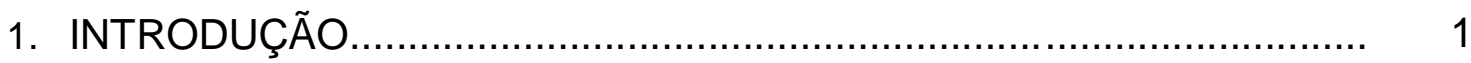

2. REVISÃO DE LITERATURA..................................................... 10

2.1. Aspectos históricos............................................................ $\quad 10$

2.2. Fatores associados............................................................ 14

2.2.1. Tipo de água ingerida.................................................... 16

2.2.2. Gestação e fatores relacionados......................................... 18

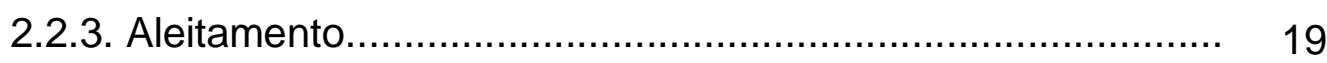

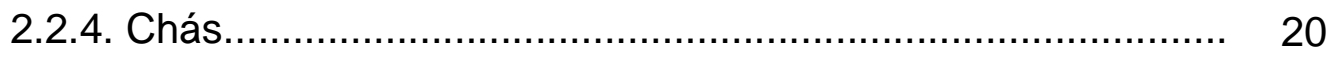

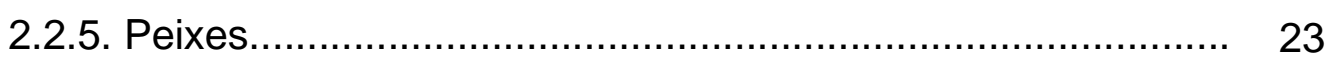

2.2.6. Água para preparo de alimentos........................................ $\quad 26$

2.2.7. Recipiente para preparo de alimentos................................. 28

2.2.8. Hábitos alimentares....................................................... 30

2.2.9. Bochechos e géis fluoretados........................................... 36

2.2.10. Dentifrícios fluoretados ................................................... 38

2.2.11. Medicamentos e suplementos com flúor............................ 49

2.2.12. Fatores sócio-econômicos.............................................. 55

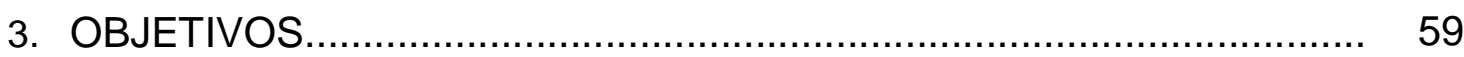

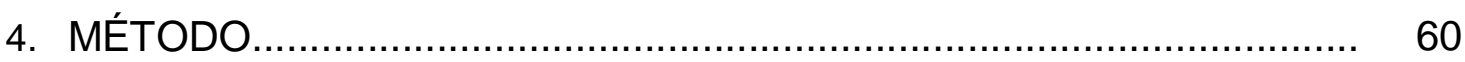

4.1. Contexto da pesquisa........................................................... 60

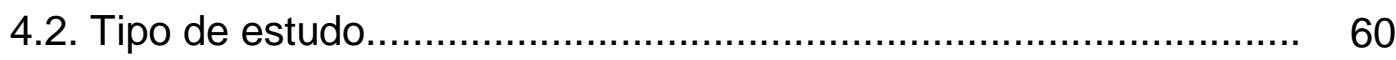

4.3. Local do estudo................................................................. 60

4.4. Planejamento da pesquisa........................................................ 65

4.5. População de estudo................................................................ 66

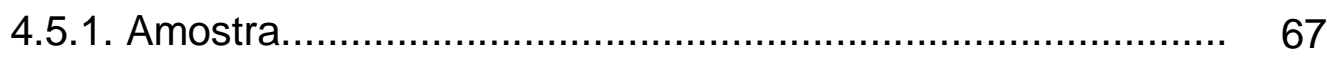

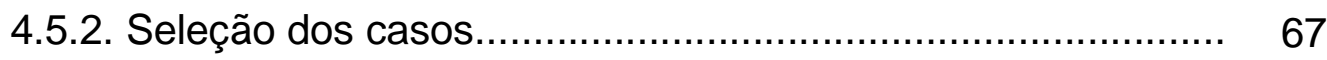

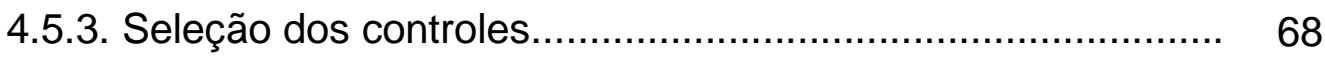

4.5.4. Controle da qualidade da base de estudo............................ 69

4.6. Instrumento de coleta dos dados.............................................. 69

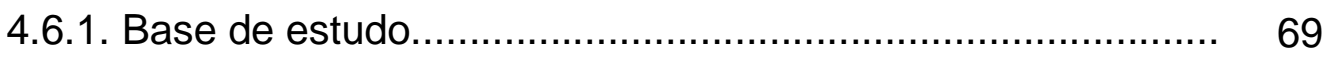


4.6.2. Formulário de entrevista.................................................... $\quad 70$

4.6.2.1. Primeira etapa da pesquisa exploratória.................... 71

4.6.2.2. Segunda etapa da pesquisa exploratória................... 71

4.6.2.3. Terceira etapa da pesquisa exploratória.................... 72

4.7. Treinamento dos entrevistadores.............................................. $\quad 74$

4.8. Monitoramento do processo de entrevistas.................................. $\quad 77$

4.9. Variáveis de estudo................................................................. 77

4.9.1. Variável dependente......................................................... 77

4.9.2. Variáveis independentes................................................ 78

4.10. Conferência e transcrição dos formulários de entrevista ............. 88

4.11. Digitação dos dados................................................................ 89

4.12. Análise dos dados............................................................... 89

4.13. Aspectos éticos ............................................................... 94

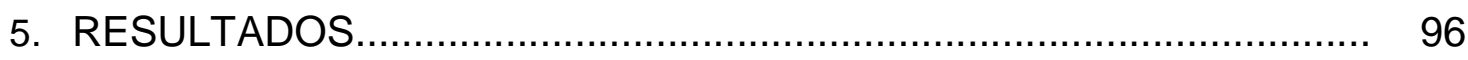

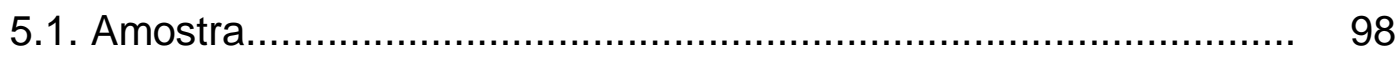

5.2. Percepção do comprometimento estético.................................. 101

5.3. Grau de escolaridade e profissão dos pais................................... 102

5.4. Aleitamento materno no primeiro ano de vida.............................. 105

5.5. Água para ingestão e para preparo de alimentos.......................... 105

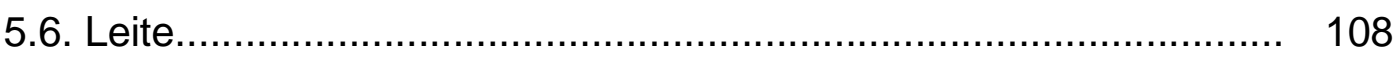

5.7. Chá

5.8. Recipiente para preparo de alimentos........................................ 110

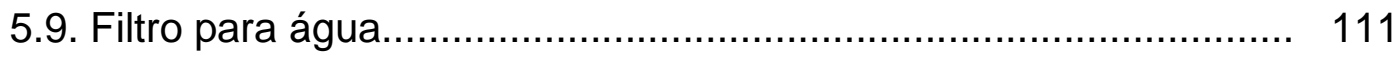

5.10. Sucos e bebidas................................................................. 111

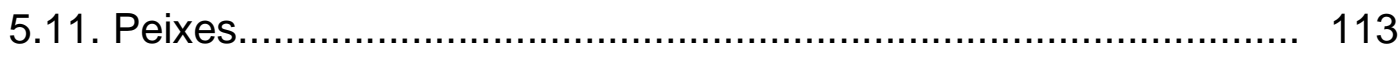

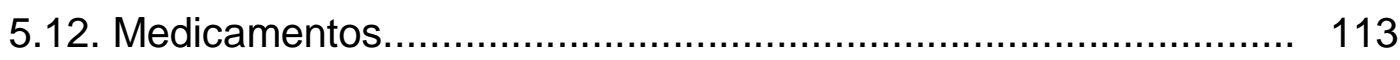

5.13. Responsável pela prescrição de medicamentos......................... 115

5.14. Produtos para bochechos domésticos....................................... 116

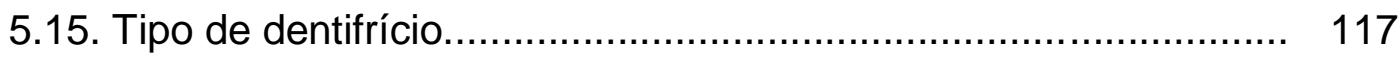

5.16. Quantidade de dentifŕcio................................................... 118

5.17. Responsável pela colocação de dentifrício................................. 119 
5.18. Tamanho da cabeça da escova de dentes.

5.19. Idade de início do uso de dentifrícios, escovações diárias e enxágües após a escovação.

5.20. Ingestão de dentifrícios 122

5.21. Produto com flúor e freqüência de utilização na pré-escola. 122

5.22. Variáveis sócio-econômicas. 123

5.23. Variáveis relacionadas à água. 126

5.24. Variáveis relacionadas ao uso de dentifrícios. 127

5.25. Variáveis relacionadas à exposição a flúor na escola 128

5.26. Análise univariada. 131

5.30. Modelo de regressão logística múltipla não condicional. 133 6. DISCUSSÃO. 135

6.1. Percepção do comprometimento estético. 140

6.2. Aleitamento materno no primeiro ano de vida 141

6.3. Recipiente para preparo de alimentos. 142

6.4. Hábitos alimentares 143

6.4.1. Leite associado a fórmulas e complementos. 143 6.4.2. Chá 144

6.4.3. Sucos e bebidas 145 6.4.4. Peixes. 145

6.5. Medicamentos e seus prescritores 146

6.6. Uso de produtos para bochechos domésticos. 147

6.7. Fatores relacionados à exposição na pré-escola 147

6.8. Fatores sócio-econômicos. 148

6.9. Fatores relacionados à exposição à água. 150

6.10. Fatores relacionados ao uso de dentifrícios. 153

7. CONSIDERAÇÕES FINAIS 157

8. REFERÊNCIAS. 159 ANEXOS. 178

Anexo 1: Relação de casos e controles por escola de ensino fundamental.

Anexo 2: Planilha de exames para cálculo de concordâncias interexaminadores Anexo 3: Relação de medicamentos com flúor. 
Anexo 4: Relação de fórmulas infantis à base de soja.

Anexo 5: Fotografia para identificação de escovas de dentes.

Anexo 6: Esquema para identificação de quantidade de dentifrício.

Anexo 7: Formulário de entrevista.

Anexo 8: Protocolo para transcrição de respostas.

Anexo 9: Ficha para transcrição de respostas.

Anexo 10: Aprovação pelo Comitê de Ética da FSP-USP

Anexo 11: Termo de consentimento livre e esclarecido.

\section{ÍNDICE DE QUADROS}

1. Número de entrevistas distribuídas segundo profissional. Ribeirão Pires, São Paulo, Brasil, 2005.

2. Recursos do Programa SPSS for Windows 10.0 utilizados na categorização de variáveis.

\section{ÍNDICE DE FIGURAS}

1. Divisão Regional do Município de Ribeirão Pires 


\section{ÍNDICE DE TABELAS}

1. Número, porcentagem e intervalos de confiança (95\%) da amostra segundo a condição de esmalte para fluorose dentária. Ribeirão Pires, São Paulo, Brasil, 1997 e 2000.

2. Quantidade de dentifrício colocado sobre a escova dental de acordo com técnica/escova empregadas e sua relação com a dose de flúor ingerida.

3. Freqüências absolutas de água para preparo de alimentos segundo categoria da variável e ciclos de vida. Ribeirão Pires, São Paulo, Brasil, 2005.

\section{1}

4. Freqüências absolutas (1) de água para preparo de alimentos segundo fonte de água ao longo dos ciclos. Ribeirão Pires, São Paulo, Brasil, 2005.

5. Freqüências absolutas (2) de água para preparo de alimentos segundo fonte de água ao longo dos ciclos. Ribeirão Pires, São Paulo, Brasil, 2005

6. Freqüências absolutas (3) de água para preparo de alimentos segundo fonte de água ao longo dos ciclos. Ribeirão Pires, São Paulo, Brasil, 2005

7. Número e porcentagem de casos e controles segundo região da residência, residência nos primeiros 6 anos de vida, sexo, idade e etnia. Ribeirão Pires, São Paulo, Brasil, 2004.

8. Número e porcentagem de casos segundo graus de fluorose (Índice de Dean). Ribeirão Pires, São Paulo, Brasil, 2005.

9. Número e porcentagem de casos segundo dentes parâmetros para identificação da fluorose dentária. Ribeirão Pires, 2005.

10. Número e porcentagem de entrevistados responsáveis por casos de fluorose dentária segundo percepção das alterações nos dentes. Ribeirão Pires, São Paulo, Brasil, 2005.

11. Porcentagem de casos e controles segundo grau de escolaridade do pai e grau de escolaridade da mãe. Ribeirão Pires, São Paulo, Brasil, 2005

12. Porcentagem de casos e controles segundo profissão do pai. Ribeirão Pires, São Paulo, Brasil, 2005...

13. Porcentagem de casos e controles segundo profissão da mãe. Ribeirão Pires, São Paulo, Brasil, 2005...

14. Média, desvio padrão, mediana e quartis da duração do aleitamento materno no primeiro ano de vida. Ribeirão Pires, São Paulo, Brasil, 2005.

15. Porcentagem de casos e controles segundo tipo de água ingerida e ciclo de vida. Ribeirão Pires, São Paulo, Brasil, 2004.

16. Porcentagem de casos e controles segundo tipo de água para preparo de alimentos e ciclo de vida. Ribeirão Pires, São Paulo, Brasil, 2005.

17. Porcentagem de casos e controles segundo tipo de leite ingerido e ciclo de vida. Ribeirão Pires, São Paulo, Brasil, 2005.

18. Porcentagem de casos e controles segundo tipo de chá ingerido e ciclo de vida. Ribeirão Pires, São Paulo, Brasil, 2005. 
19. Porcentagem de casos e controles segundo tipo de recipiente para preparo de alimentos e ciclo de vida. Ribeirão Pires, São Paulo, Brasil, 2005.

20. Porcentagem de casos e controles segundo uso de filtro para água e ciclo de vida. Ribeirão Pires, São Paulo, Brasil, 2005

21. Porcentagem de casos e controles segundo tipo de suco ingerido e ciclo de vida. Ribeirão Pires, São Paulo, Brasil, 2005.

22. Porcentagem de casos e controles segundo tipo de bebida ingerida e ciclo de vida. Ribeirão Pires, São Paulo, Brasil, 2005.

23. Porcentagem de casos e controles segundo tipo de peixe consumido e ciclo de vida. Ribeirão Pires, São Paulo, Brasil, 2005.

24. Porcentagem de casos e controles segundo tipo de medicamento utilizado na gestação. Ribeirão Pires, São Paulo, Brasil, 2005.

25. Porcentagem de casos e controles segundo tipo de medicamento utilizado e ciclo de vida. Ribeirão Pires, São Paulo, Brasil, 2005...

26. Porcentagem de casos e controles segundo responsável pela prescrição de medicamento e ciclo de vida. Ribeirão Pires, São Paulo, Brasil, 2005.

27. Porcentagem de casos e controles segundo tipo de produto utilizado para bochecho doméstico e ciclo de vida. Ribeirão Pires, São Paulo, Brasil, 2005.

28. Porcentagem de casos e controles segundo tipo de dentifrício utilizado e ciclo de vida. Ribeirão Pires, São Paulo, Brasil, 2005.

29. Porcentagem de casos e controles segundo quantidade de dentifrício utilizada e ciclo de vida. Ribeirão Pires, São Paulo, Brasil, 2005.

30. Porcentagem de casos e controles segundo responsável pela colocação de dentifrício e ciclo de vida. Ribeirão Pires, São Paulo, Brasil, 2005.

31. Porcentagem de casos e controles segundo tamanho da cabeça da escova e ciclo de vida. Ribeirão Pires, São Paulo, Brasil, 2005.

32. Medidas descritivas relativas às variáveis de exposição a flúor em adolescentes casos e controles em área com água fluoretada. Ribeirão Pires, São Paulo, Brasil, 2005

33. Porcentagem de casos e controles segundo tipo de produto com flúor utilizado na pré-escola. Ribeirão Pires, São Paulo, Brasil, 2005

34. Porcentagem de casos e controles segundo freqüência semanal de produto com flúor na pré-escola. Ribeirão Pires, São Paulo, Brasil, 2005.

35. Porcentagem de casos e controles segundo variáveis sócioeconômicas. Ribeirão Pires, São Paulo, Brasil 2005.

36. Porcentagem de casos e controles segundo variáveis relacionadas à água. Ribeirão Pires, São Paulo, Brasil, 2005.

37. Porcentagem de casos e controles segundo variáveis relacionadas ao uso de dentifrícios. Ribeirão Pires, São Paulo, Brasil, 2005.

38. Porcentagem de casos e controles segundo variáveis relacionadas à exposição a flúor na pré-escola. Ribeirão Pires, São Paulo, Brasil, 2004. 
39. Análise univariada da fluorose dentária em adolescentes residentes em área fluoretada segundo exposição a flúor e escolaridade dos pais. Ribeirão Pires, São Paulo, Brasil, 2005.

40. Fluorose dentária em adolescentes residentes em área fluoretada segundo exposição a flúor e escolaridade dos pais. Odds Ratio bruta, ajustada e intervalos de confiança (IC95\%) Ribeirão Pires, São Paulo, Brasil, 2005 


\section{INTRODUÇÃO}

A fluorose dentária é a manifestação da intoxicação crônica por flúor, caracterizada por um distúrbio de desenvolvimento do esmalte e, em casos mais raros, da dentina, durante a formação do dente (FEJERSKOV et al. 1977).

Estimativas das doses tóxicas de flúor que representam limite máximo de risco para o indivíduo em função do peso e da idade foram estabelecidas por BURT (1992) e a complexidade de se estudar mecanismos relacionados à toxicidade crônica do flúor em seres humanos foi destacada por FEJERSKOV et al. (1977).

O flúor retarda a mineralização do esmalte, afetando a estrutura e o crescimento dos cristais de apatita, substituindo a hidroxila na estrutura do cristal, que tem seu volume reduzido, com maior incremento de cristais (AOBA 1997). Microscopicamente, o esmalte apresenta-se mais poroso, sendo que o grau e a extensão da porosidade vai depender da concentração de flúor nos tecidos durante a formação dos dentes (FEJERSKOV et al. 1994).

O período crítico de exposição a doses excessivas de flúor para as duas dentições é do nascimento até oito anos de idade (MASCARENHAS 2000). Para comprometimento dos incisivos centrais, a exposição por mais de dois anos durante os quatro primeiros anos de vida é crítica (BARDSEN 1999).

Os aspectos clínicos da fluorose dentária são definidos por um conjunto de alterações que têm como características clínicas, para diagnóstico diferencial em relação a outras opacidades, simetria e bilateralidade, afetando dentes ou grupos de dentes que se formaram na mesma época. Podem ser estrias ou finas linhas brancas opacas cruzando horizontalmente o dente e ocupando parte do esmalte ou apenas as cristas marginais e bordas incisais (fluorose muito leve). Essas alterações podem se apresentar como grandes manchas brancas opacas, irregulares e nebulosas (fluorose leve) que, em uma condição mais grave, podem compreender toda 
a superfície do dente, como uma extensa área opaca de aspecto branco calcáreo; cuja porção mais externa pode sofrer desgastes formando depressões, as quais vão se pigmentando em razão de corantes naturais e artificiais, entre outros fatores, tornando-se manchas marrom-acastanhadas (fluorose moderada). Após um período de exposição ao ambiente bucal, essas depressões podem se fundir e formar grandes áreas acastanhadas, alterando a anatomia dos dentes (fluorose severa). É importante observar que as depressões e manchas são um fenômeno secundário da fluorose, ou seja, são observadas somente após um período de tempo depois do irrompimento do dente e exposição ao meio bucal.

Essa característica do esmalte dentário permitiu que durante muito tempo o agravo fosse denominado de "esmalte mosqueado". A denominação fluorose dentária apareceu inicialmente na publicação de DEAN e ELVOLVE (1935) e foi considerada por DEAN (1943) mais adequada pelo fato de que, segundo o autor, o fator etiológico do agravo era o flúor.

A fluorose descrita nos estudos clássicos era produzida pela exposição a um único fator: geralmente águas de poços profundos ou águas superficiais em determinadas regiões, que foram consumidas pela população por período prolongado. Devido ao alto teor de flúor natural contido nessas águas, era produzido um quadro típico nos indivíduos, de característica endêmica, onde uma porcentagem significativa da população exposta apresentava formas de fluorose dentária do tipo severa, moderada ou leve.

A ocorrência da fluorose dentária em áreas endêmicas, a torna mais importante que outros agravos de saúde bucal considerados problemas de saúde pública (CHAVES 1986).

Para FRAZÃO (1999):

"Saúde pública, numa definição prática, é o diagnóstico científico dos problemas de saúde de uma comunidade e a aplicação de medidas individuais e coletivas para controlar esses problemas, evitando sua progressão ou reduzindo sua ocorrência para níveis 
suportáveis do ponto de vista econômico e aceitáveis do ponto de vista social. Portanto, transcende a saúde no plano individual objeto da clínica médica - e não deve ser confundida com "saúde estatal" ou aquela realizada apenas pelo Estado. Organizações não estatais podem e devem implementar medidas coletivas que favoreçam a saúde de seus usuários. Por estas e outras razões, denomina-se esta área de conhecimento de Saúde Coletiva".

CHAVES (1986, p.24) considerou que a forma mais didática para se caracterizar um problema de saúde pública é a proposta por Sinai, havendo a necessidade do preenchimento de três condições: constituir causa comum de morbidade ou de mortalidade, existirem métodos eficazes de prevenção e controle e tais métodos não estarem sendo utilizados de modo adequado pela comunidade. Acrescentou, ainda, que os principais critérios para estabelecer a prioridade relativa dos problemas de saúde pública são: número de pessoas atingidas, seriedade do dano causado, possibilidade de atuação eficiente, custo per capita e grau de interesse da comunidade.

Para NARVAI (2002), a importância da fluorose dentária endêmica, aquela que acomete grupos populacionais concomitantemente, decorrente de uma fonte comum de água, como problema de saúde pública é incontestável (WHO 1984) e onde for detectada merecerá intervenção imediata. O autor descreveu mais dois outros tipos de fluorose dentária: iatrogênica e iatrogênica endêmica. Considerou fluorose dentária iatrogênica aquela que se apresenta como casos únicos (exceções), decorrentes da ingestão individual inadequada de produto fluoretado. A fluorose dentária iatrogênica endêmica é aquela decorrente da exposição a múltiplas fontes de flúor.

NARVAI (1999) exemplificou essa última com algumas situações em que a fluorose dentária poderia ocorrer devido à associação de meios de uso de flúor; tanto sistêmicos quanto da ingestão a partir de meios tópicos por tempo prolongado. Segundo o autor, tais combinações poderiam produzir quadros de fluorose dentária em graus variados, predominando as formas 
muito leve e leve, mas podendo chegar a moderada ou severa. Para ele, diferenciava-se da "endêmica" e da "iatrogênica" pelas características da sua distribuição na população. NARVAI (2002) acrescentou que a diferenciação entre os três tipos de fluorose seria relevante para a saúde pública, uma vez que cada uma delas implicaria um tipo de intervenção.

O descritor iatrogenia é assim definido (BVS 2001):

"condição adversa em um paciente que ocorre como resultado de tratamento por um médico, cirurgião ou outro profissional da área da saúde, especialmente infecções adquiridas pelo curso do tratamento".

Utilizar as nomenclaturas sugeridas por NARVAI (2002) pode facilitar a distinção entre as características dos três quadros epidemiológicos de fluorose dentária, mas é importante não se desprezar o conhecimento de que essa fluorose "iatrogênica" pode ter ocorrido como resultado de ações individuais ou outros tipos de exposição ao flúor; não relacionados a tratamentos por profissionais da área da saúde.

As características singulares desse terceiro tipo de fluorose dentária têm feito com que, no início do século XXI, tenha-se estabelecido, em nível mundial, um importante debate sobre a emergência da fluorose dentária como um problema de saúde pública (NARVAI 1999).

Levando-se em conta os critérios estabelecidos por CHAVES (1986) para a priorização dos problemas de saúde pública, quanto à fluorose dentária iatrogênica endêmica não se pode afirmar o mesmo, uma vez que em grande número de situações, ela não é percebida como problema relevante pela população atingida (SILVA 2000; MENEZES et al. 2002; MOYSÉS et al. 2002) e isso pode ser devido à baixa prevalência de problemas estéticos decorrentes (CLARK e BERKOWITZ 1997). Nem sempre a alta prevalência de fluorose dentária vai caracterizá-la como um problema de saúde pública.

Existem aspectos relacionados aos campos de força e aos paradigmas de bem-estar (DEVER 1988), que devem ser considerados na 
determinação dos níveis de saúde-doença das populações quando se avalia a fluorose dentária.

O determinante ambiental do agravo pode ser representado pelas políticas públicas que possibilitam à população o acesso à água fluoretada com seus teores controlados. O comportamental tem um papel muito importante, pois hábitos de ingestão de dentifrícios, hábitos alimentares e auto-medicação podem exercer grande força na ocorrência do agravo. Em relação à organização dos serviços de saúde, este determinante tem seu papel, principalmente no que diz respeito à capacitação dos profissionais em relação a orientações educativas e prescrições medicamentosas. O determinante biológico é o que exige maior cuidado, pois, como já foi destacado, é bastante complexo o estudo dos mecanismos relacionados à toxicidade crônica do flúor em seres humanos (FEJERSKOV et al. 1977), pois a maioria dos estudos foi realizada com animais.

No aspecto biológico, o conceito de plasticidade, isto é, a capacidade de uma célula, tecido ou órgão de como resultado de ativações sucessivas, se e alterar a sua resposta, pode ser utilizado para se compreender as alterações ocorridas no desenvolvimento da fluorose dentária e caracterizála como patologia ou não. Essa resposta pode ocorrer em três níveis durante o desenvolvimento: seleção de genótipo apropriado, modificação do fenótipo e respostas comportamentais ou fisiológicas para a formação individual (PRITCHARD 1995).

As alterações relacionadas à fluorose dentária poderiam ser consideradas, no segundo nível relativo à modificação do fenótipo. Neste nível, a variação pode ocorrer na função (mecanismo regulador) ou na forma (mecanismo estrutural - "mosaico"). Nesse processo de desenvolvimento essa plasticidade modula não apenas a resposta dos tecidos para as influências externas mas também a geração de influências que produzem respostas outros tecidos. Quando é adotado o mecanismo regulador, a espécie pode tornar-se mais vulnerável a fatores teratogênicos. Isso significa que a plasticidade embrionária é um fator importante na diferenciação 
normal e no desenvolvimento, mas, em algumas situações, ela pode se tornar uma patologia (PRITCHARD 1995).

Segundo FEJERSKOV et al. (1977), no desenvolvimento da fluorose dentária, as alterações podem se dar nos ameloblastos (mecanismo estrutural) ou na formação dos cristais de apatita e homeostase do cálcio (mecanismo regulador).

AOBA (1997) fez uma descrição mais detalhada da participação do flúor na estrutura e crescimento dos cristais de apatita citada por FEJERSKOV et al (1977). Destacou que o efeito mais bem documentado do flúor seria a substituição da hidroxila na estrutura da apatita, reduzindo o volume do cristal e permitindo um maior incremento de cristais, aumentando a sua estabilidade, mas, o excesso de flúor iria retardar a mineralização do tecido (mecanismo regulador).

AOBA e FEJERSKOV (2003) apontaram que a relação dose-resposta era claramente linear. Não foi possível identificar um limiar inferior de ingestão de flúor a partir do qual seu efeito no esmalte não se manifeste. Segundo os autores, após vários estudos pode-se considerar que o efeito patogênico do flúor provavelmente não é no metabolismo celular e/ou sistêmico metabólico e sim um efeito local na matriz do esmalte em mineralização. Assim, durante a amelogênese, a matriz protéica secretada pelo ameloblasto sofre reabsorção por proteinases cálcio-dependentes e na ausência de flúor a concentração de cálcio no fluido do esmalte é suficiente para ativar a hidrólise protéica. Entretanto, na presença do flúor a concentração de cálcio livre é reduzida, diminuindo a atividade das proteases resultando em uma diminuição da degradação e remoção de proteínas durante a maturação do esmalte (mecanismo regulador). Como conseqüência forma-se um esmalte mais poroso e isto pode se refletir em opacidade dependendo da dose de exposição ao flúor.

Como as alterações durante a formação do esmalte que levam à ocorrência de fluorose dentária ocorrem preponderantemente no mecanismo regulador (FEJERSKOV et al. 1977; AOBA 1997; AOBA e FEJERSKOV 
2003), pode-se considerá-la como um quadro patológico, decorrente das alterações da resposta celular e tissular às modificações do meio interno e externo (PRITCHAD 1995).

Em uma discussão sobre a Teoria Geral da Saúde, ALMEIDA FILHO (2001) identificou três planos hierárquicos de emergência ou manifestação de diferentes modos de saúde: planos individual, subindividual e coletivo. Os vários modos de saúde poderiam ser denominados saúde normal, saúde privada, saúde individual, ausência de risco (1 - risco), saúde e saúde social); e as categorias correspondentes de não-saúde poderiam ser definidas como patologia, transtorno, enfermidade, risco, morbidade e doença. Ambos estavam organizados de acordo com os planos hierárquicos de emergência. No plano subindividual poderiam ser identificadas as esferas sistêmica, tissular, celular e molecular. No plano individual considerou a clínica e a esfera privada e, no nível coletivo, as esferas epidemiológica, populacional e social.

Assim, ao se considerar a fluorose dentária no plano subindividual ela poderia ser considerada uma patologia, visto que o modo de saúde correspondente seria a normalidade. No nível individual, poderia ser considerada um transtorno ou uma enfermidade, visto que o modo de saúde correspondente seria saúde normal, que dependeria da representação para o indivíduo. No nível coletivo seria considerada risco, morbidade ou doença, visto que os modos de saúde correspondentes seriam: ausência de risco, saúde e saúde social.

A saúde pública, atuando em nível coletivo, irá adotar medidas no sentido de conhecer o risco e controlar os fatores a ele associados, buscando garantir a saúde social. As áreas de atuação da saúde pública para adoção de medidas de prevenção e controle da fluorose dentária são: educação em saúde, vigilância sanitária e vigilância epidemiológica (FORNI 2000).

No campo da Vigilância Epidemiológica (BRASIL 1990), entre as medidas a serem destacadas estão os levantamentos epidemiológicos, que, 
segundo a Organização Mundial da Saúde, devem ser realizados a cada cinco anos (WHO 1987; WHO 1997), com o objetivo de se conhecer a prevalência e severidade do agravo.

A condução de levantamentos epidemiológicos de fluorose dentária tem se dado no município de Ribeirão Pires - SP nos últimos sete anos. Em 1.997, a Faculdade de Saúde Pública da Universidade de São Paulo (FSPUSP) realizou, em parceria com a Direção Regional de Saúde II - Santo André, levantamentos exploratórios de fluorose dentária nos sete municípios que compõem a região (USP-FSP 2000). Os resultados do estudo para o município de Ribeirão Pires (FORNI 2000; USP-FSP 2000), embora não conclusivos, indicaram prevalência de fluorose dentária acima dos percentuais considerados aceitáveis por DEAN (1936) e apontaram a necessidade de estudos com maior acurácia para verificar a magnitude da ocorrência do problema no local.

Com esse objetivo, a Faculdade de Odontologia da Universidade Metodista de São Paulo, em parceria com a Secretaria Municipal de Saúde do Município de Ribeirão Pires, realizou, em 2.000, um estudo epidemiológico transversal de fluorose dentária em escolares de 12 anos no qual se buscou minimizar as limitações identificadas no estudo exploratório (UMESP 2001). FRAZÃO et al. (2004) compararam esses dois estudos (Tabela 1) e levantaram a hipótese de que a diferença nos resultados poderia ter se dado pela utilização de metodologias diferentes de classificação da fluorose dentária, em relação aos dentes afetados.

$\mathrm{Na}$ segunda pesquisa, os resultados reforçaram taxas de fluorose dentária acima dos percentuais de 10 a 15\% considerados aceitáveis por DEAN (1936). Além do conhecimento da prevalência e severidade da fluorose dentária, a pesquisa buscou obter outras informações que permitissem o desenvolvimento de um estudo analítico de forma a possibilitar a identificação de fatores associados ao agravo. 
Tabela 1 - Número, porcentagem e intervalos de confiança (95\%) da amostra segundo a condição do esmalte para fluorose dentária. Ribeirão Pires, São Paulo, Brasil, 1997 e 2000.

\begin{tabular}{lrrrrrc}
\hline \multirow{2}{*}{ Condição do esmalte } & \multicolumn{3}{c}{ Estudo A (1997) } & \multicolumn{3}{c}{ Estudo B (2000) } \\
& \multicolumn{1}{c}{$\mathrm{n}$} & \multicolumn{1}{c}{$\%$} & $\mathrm{IC} 95 \%$ & $\mathrm{~N}$ & $\%$ & \multicolumn{1}{c}{ IC 95\% } \\
\hline Sem fluorose & 97 & 37,5 & $31,5-43,7$ & 205 & 66,8 & $61,2-72,0$ \\
Com fluorose & 162 & 62,5 & $56,3-68,5$ & 102 & 33,2 & $27,9-38,8$ \\
$\quad$ Muito leve & 153 & 59,1 & $52,8-65,1$ & 83 & 27,1 & $22,1-32,4$ \\
Leve & 8 & 3,1 & $1,3-5,9$ & 16 & 5,2 & $3,0-8,3$ \\
\multicolumn{1}{c}{ Moderada + severa } & 1 & 1 & - & 3 & 0,9 & $0,2-2,8$ \\
\hline Total & 259 & 100,0 & - & 307 & 100,0 & - \\
\hline
\end{tabular}

Fonte: FRAZÃO et al. (2004, p. 1054)

Em seu relatório final, a conclusão foi recomendar às autoridades sanitárias do município que, enquanto novos e mais conclusivos conhecimentos fossem gerados, deveriam manter as bases do sistema de prevenção adotado - uso de água e dentifrício fluoretado; com maior precisão e ênfase nas medidas de vigilância sanitária sobre esses e outros produtos fluoretados, de modo a assegurar o máximo de benefício com 0 mínimo de risco para fluorose dentária (UMESP 2001).

Em locais com teores adequados de flúor na água de abastecimento, além da redução da prevalência de cárie dentária, taxas de fluorose dentária em torno de $20 \%$, dependendo do índice utilizado, têm sido observadas. Por essa razão, pesquisas para identificar os principais fatores associados à fluorose dentária em populações são muito importantes. Entre os fatores que têm sido apontados como possíveis causas destacam-se os suplementos e dentifrícios fluoretados e as fórmulas infantis (BOWEN 2002).

A produção de conhecimento sobre a influência das múltiplas fontes de flúor na prevalência de fluorose dentária em populações expostas à água fluoretada é essencial para todos os responsáveis pela gestão dos serviços e sistemas de saúde. Tendo em vista o que foi relatado, considerou-se oportuno a realização de um estudo detalhado no município de Ribeirão Pires - SP sobre os possíveis fatores associados às taxas de prevalência de fluorose dentária. 


\section{REVISÃO DE LITERATURA}

\subsection{Aspectos históricos}

Os relatos na literatura científica sobre a ocorrência da fluorose dentária destacaram sua associação com alguma substância na água potável e a sua ocorrência desde os períodos mais remotos da civilização humana, comprovada pela observação de alterações em dentes de crânios com milhares de anos (FEJERSKOV et al. 1994).

De acordo com PEREIRA (1996, p.5), as primeiras constatações da presença deste tipo de alteração dentária foram feitas por Khuns (1888), o qual descreveu manchas escuras em dentes de uma família em Durango (México).

$\mathrm{Na}$ função de cirurgião assistente do U.S. Marine Hospital Service, EAGER (1901), ao examinar imigrantes italianos grevistas que embarcaram em um porto de Nápoles, observou casos de uma peculiaridade dentária comum em habitantes do litoral italiano, conhecida como "dente de Chiaie". Esse defeito foi descrito por Stefano de Chiaie, que denominou a alteração com o seu sobrenome (BUENDIA 1996, p.5).

Segundo EAGER (1901), as imperfeições nos dentes despertaram interesse pelos seguintes fatos: aconteceram nos italianos anteriormente a qualquer intervenção por profissionais americanos, foram adquiridas devido a condições geológicas locais e não eram transmitidas aos descendentes dos italianos. O autor relatou que a etiologia do "dente de Chiaie" foi relacionada a gases vulcânicos ou a emanações subterrâneas lançadas na atmosfera ou formando soluções na água utilizada para consumo. Segundo o autor, na cidade de Nápoles (Itália) as alterações foram mais atribuídas à água.

Ao contrário, em Pozzuoli, cidade próxima à Nápoles (Itália), foram inicialmente atribuídas a gases tóxicos provenientes da erupção vulcânica. As alterações descritas como "dente de Chiaie" variavam desde finas linhas brancas horizontais, dentes totalmente brancos, marrons ou pretos, sendo 
completamente diferentes de outros distúrbios dentários, improvável, segundo o autor, de serem confundidas com dentes de Hutchinson, anomalias causadas por mercúrio, cárie dentária ou outras (EAGER 1901).

McKAY e BLACK $\left(1916^{a}\right)$ relataram que alguns dentistas residentes em Rocky Mountain (Colorado, Estados Unidos) descreveram uma condição peculiar dos dentes de uma larga proporção da população das redondezas. Acrescentaram que, segundo os profissionais, essa característica não tinha sido observada em nenhum outro local e não tinha sido descrita na literatura, e a denominaram de "esmalte mosqueado" ou "dente mosqueado". Os autores solicitaram alguns desses dentes para exame e receberam coroas de incisivos com a alteração que tinham sido extraídos com o propósito de substituição por coroas artificiais. Essas alterações foram encontradas em 70 a $100 \%$ das pessoas que nasceram e residiam nas áreas de ocorrência. Analisaram as características histológicas desses dentes e as descreveram. Examinaram crianças e adultos das regiões mais suscetíveis. Observaram que os dentes tinham forma normal, porém com coloração alterada. Quando não eram marrons ou amarelos eram extremamente esbranquiçados e opacos. Analisando casos esporádicos observados em outras regiões, os autores associaram ao fato de os indivíduos terem vivido um determinado período de sua vida em área endêmica, e estabeleceram relações com grupos de dentes que se formaram naquele período.

McKAY e BLACK (1916 ${ }^{\text {b }}$ ) descreveram as alterações macroscópicas do esmalte dentário e apresentaram teorias sobre a etiologia do agravo. Para os autores, se a descoloração era interna à estrutura do esmalte, deveria acontecer quando este estava se formando; isto é, alguma combinação química desconhecida poderia se formar e se depositar na estrutura dos ameloblastos.

McKAY (1929) estabeleceu a relação entre o "esmalte mosqueado" e sua responsabilidade na cárie dentária. Considerou que a população mais adequada para se estabelecer essa relação deveria apresentar as seguintes condições: por conveniência, deveria ser pequena; o defeito deveria estar 
presente no esmalte formado ou em formação nessa comunidade; a condição social e os hábitos alimentares deveriam ser uniformes entre os habitantes, e um mesmo indivíduo deveria ter tanto esmalte normal quanto "esmalte mosqueado". Examinou crianças de comunidades de Tower (Colorado), Bruneau (Idaho) e Sacaton (Arizona) e concluiu que o "esmalte mosqueado" por sua estrutura defeituosa não era mais suscetível à cárie que o esmalte normal e, quando esta acontecia, era devido às mesmas razões e acometia as mesmas superfícies.

$\operatorname{KEMPF}$ e McKAY (1930, p.3) destacaram as investigações realizadas por McKay nos distritos americanos de Colorado, Texas, Virgínia e Arizona, publicadas no período de maio a agosto de 1916. Relataram que, em 1917, foram avaliadas áreas endêmicas nos Estados Unidos em South Dakota e posteriormente estendeu as investigações para áreas em Idaho e Califórnia e depois em Illinois, North Dakota e Minnesota. Também mencionaram a ocorrência do problema em outras partes do mundo: Itália, Ilhas Bahamas, Barbados, Holanda, Ilha de Cabo Verde, países da América do Sul e África do Sul.

Em 1919, McKAY (1933) observou nos dentes de crianças de uma pequena comunidade rural americana (Oakley, Idaho) uma alteração desfigurante, cuja causa era desconhecida. A condição não era encontrada nas crianças que residiam fora do local. Após a coleta de várias informações, identificou que o defeito do esmalte começou a aparecer nas crianças após seis ou sete anos de uso de uma fonte de água localizada a cinco milhas de distância. Examinando crianças que fizeram uso de água de outra fonte localizada a três ou quatro milhas da comunidade, observou que não apresentavam as alterações. Em 1925, por decisão da autoridade sanitária local, uma nova fonte de água foi canalizada para uso da comunidade, sendo abandonada a fonte anterior, hipótese causal do problema.

Em 1.933, foram efetuados exames nas crianças que consumiram água da nova fonte desde o nascimento ou algum tempo após. As que 
consumiram desde o nascimento não apresentaram nenhuma alteração, e as que começaram a utilizar a água após seis meses apresentaram pequenas alterações em primeiros molares e incisivos. As que começaram a usar a água após os cinco anos de idade, salvo algumas exceções, apresentaram todos os dentes comprometidos.

KEMPF e McKAY (1930) descrevem um estudo realizado em 1927 em Bauxite (Arkansas, Estados Unidos), onde foram estabelecidas comparações com grupos de crianças em três situações: expostas à água de poços municipais profundos desde o nascimento, expostas apenas durante a idade escolar e um terceiro grupo que residia em outro município (Benton, no mesmo estado). Os resultados da pesquisa mostraram que as crianças que nasceram em Bauxite e as que viveram durante o período escolar apresentaram o agravo; enquanto que as que nasceram e viveram em Benton não o apresentavam.

CHURCHILL (1931, p.996) relatou que após a publicação de KEMPF e McKAY (1930), Petrey identificou a presença de flúor na água de abastecimento de Bauxite (Arkansas, Estados Unidos). Após essa descoberta, também analisou a água de outras localidades americanas onde foi observada a alteração dentária: Colorado Springs (Colorado) e Oakley (Idaho).

Essa descoberta foi relatada por VIEGAS (1961, p.206), BASTOS et al. (1993, p.309) e BUENDIA (1996, p.6) como tendo acontecido de forma acidental, pois a água estava sendo examinada com a finalidade de se verificar a possibilidade de uso na indústria de alumínio.

A partir dessas conclusões, as pesquisas sobre o denominado "esmalte mosqueado" foram intensificadas nos Estados Unidos no período de 1933 a 1957, onde foi estabelecida a relação direta entre ocorrência e severidade da fluorose dentária e concentração de flúor na água de beber (DEAN 1933; DEAN 1934; DEAN et al. 1935; DEAN e ELVOLVE 1935; DEAN e ELVOLVE 1936; DEAN ${ }^{35}$ 1936; DEAN e ELVOLVE 1937; DEAN et 
al. 1938; DEAN et al. 1939; DEAN e McKAY 1939; DEAN 1942; DEAN 1943; DEAN 1946; GALAGAN e LAMSON 1953; GALAGAN e VERMILLION 1957).

Estudos na literatura internacional sobre a "fluorose dentária endêmica" foram conduzidos na Tanzânia (THYLSTRUP 1978; THYLSTRUP e FEJERSKOV 1978) confirmando as associações da ocorrência e severidade da fluorose dentária com o teor de flúor na água.

$\mathrm{Na}$ literatura nacional, podem ser citados estudos realizados em municípios do Estado de São Paulo como Pereira Barreto (UCHÔA e SALIBA 1970), Cosmópolis (ANDO et al. 1975) e Icém (ALCAIDE e VERONEZI 1979) e no Estado de Santa Catarina no distrito de Cocal, município de Urussunga (CAPELLA et al. 1989).

Estudos sobre a "fluorose dentária iatrogênica endêmica" têm sido descritos na literatura internacional. Como exemplos podem ser citados: WENZEL e THYLSTRUP (1982) realizado em Greve, na Dinamarca, EKLUND et al. (1987) em Deming no Novo México, EVANS e STAMM (1991) em Hong Kong, MELLA et al. (1994) em Valparaíso-Viña no Chile, HELIER et al. (1997) em levantamento epidemiológico nacional nos Estados Unidos e EL NADEEF e HONKALA (1998) em Plateau na Nigéria.

Exemplos citados na literatura nacional também podem ser destacados como os estudos de TOMITA et al. (1995) em Piratininga no Estado de São Paulo, de SAMPAIO (1993) em três municípios do Estado da Paraíba, de ALCÂNTARA (1996) em Curitiba no Estado do Paraná e de CANGUSSU et al. (2003) em Salvador, no Estado da Bahia. Além desses, vários estudos exploratórios de fluorose dentária têm sido realizados no Estado de São Paulo, cujos resultados têm indicado a ocorrência desse tipo de distribuição da fluorose dentária (USP-FSP 1999; FORNI 2000).

\subsection{Fatores associados}

O declínio da cárie e o aumento da prevalência da fluorose nas formas mais leves têm sido observados em diferentes regiões do mundo. Alguns autores observaram maior aumento proporcional em locais com 
teores deficientes de flúor na água (RIPA 1991; HOROWITZ 1992); outros observaram diferenças pequenas entre áreas fluoretadas e não fluoretadas (LEWIS e BANTING 1994; KIMMELMAN 1995) e outros, sem entrar no mérito do seu aumento, atribuíram a ocorrência das formas leves de fluorose dentária à fluoretação da água (BAWDEN 1996).

LEVY (1994) fez uma revisão crítica da literatura que tratava da ingestão do flúor, com o objetivo de identificar a tendência de exposição ao flúor por crianças que residem em áreas fluoretadas e não fluoretadas da América do Norte.

Baseado nos valores da tabela proposta por BURT (1992), com os limites máximos de ingestão diária de flúor por crianças desde os três meses até 8 anos de idade, levando em consideração o peso médio das crianças nas diversas idades; analisou resultados de vários estudos em relação à ingestão de flúor, excluindo somente o flúor contido em bochechos e aplicações tópicas profissionais. Observou que os estudos vinham identificando variações substanciais na ingestão de flúor entre os indivíduos. Segundo o autor, uma grande proporção de indivíduos estaria exposta ou ingeria bem mais do que a média de cada forma de utilização do flúor e, muitas vezes $10-20 \%$ estariam muito mais expostos do que a média. Algumas crianças provavelmente ingeriamm flúor através uma única forma que excedia a dose ótima recomendada para uma associação de métodos, aumentando o risco de fluorose dentária.

Para o autor, como a ingestão de flúor através da dieta era muito complexa e de difícil controle, maior ênfase deveria ser dada nos cuidados com as recomendações de suplementos fluoretados e na ingestão excessiva de dentifrícios enquanto risco para fluorose dentária. Desta forma, esforços precisariam ser feitos para que se conseguisse atingir o máximo de prevenção da cárie dentária, com a segurança de se causar o mínimo de fluorose dentária.

Outros fatores potenciais, em combinação ou não, têm sido investigados e cabe fazer algumas considerações a esse respeito. 


\subsubsection{Tipo de água ingerida}

O local de nascimento do indivíduo e o tempo de residência foram fatores destacados por indicarem a exposição a determinado tipo de água de abastecimento e outras ações de saúde pública desenvolvidas na região.

Conforme descrito (item 2.1 - Aspectos históricos), essa relação foi observada por nos estudos realizados nos Estados Unidos por KEMPF e McKAY (1930) em Bauxite e Benton (Arkansas) e no de McKAY (1933) em Oakley (Idaho).

Em relação ao uso de água fluoretada ou não durante os seis primeiros anos de vida, ISMAIL et al. (1993) realizaram um estudo identificando diferenças na prevalência de cárie e fluorose dentária em Truro (0,1 ppm de F) e Kentville (1,1 ppm de F) (Nova Scotia, Canadá). Em relação à fluorose dentária, as crianças residentes na área fluoretada tiveram prevalência e média de número de dentes comprometidos significativamente maior do que as que residiam em área não fluoretada $(p<0,05)$. O nível predominante de fluorose envolveu menos de uma a três faces dos dentes.

VILLA et al. (1998) em uma pesquisa do tipo caso-controle em San Felipe no vale de Aconcagua River (Chile) onde a média dos teores de flúor nos últimos dez anos foi de 0,93 ppm (0,65-1,42 ppm). Observaram que as crianças que tinham nascido depois da fluoretação tiveram um aumento significativo na chance de ter fluorose dentária $(O R=20,44 ; \mathrm{IC}=5 ; 00-83,48)$ quando comparadas com as que tinham mais de 24 meses, período em que a água foi fluoretada.

GONINI (1999), no seu estudo realizado em Londrina (São Paulo, Brasil), não encontrou diferenças estatisticamente significativas nas freqüências de fluorose dentária entre as crianças examinadas, moradoras ou não em locais com água fluoretada; tanto em relação à presença ou ausência do agravo, quanto ao agrupá-las em função do maior índice de fluorose dentária. Como os resultados se referiram ao tempo de exposição à água fluoretada ( 0 a 3 anos, entre 3 e 6 anos, e maior que 6 anos de idade) 
no município de Londrina, atribuiu ao fato de não se conhecer a exposição à água fluoretada em outros municípios antes da transferência para Londrina.

Considerações sobre as águas engarrafadas têm sido feitas na literatura científica, destacando-as como um potencial fator de risco, principalmente quando não havia controle sobre os teores de flúor nelas contido e não era feita a orientação sobre esse aspecto aos pais/responsáveis

TOUMBA e CURZON (1994) analisaram 12 tipos de águas engarrafadas (minerais ou de fontes) obtidas em dois supermercados do Reino Unido em relação aos teores de flúor existentes e os apresentados nos rótulos. Os teores observados variaram entre 0,1 e 0,8 ppm de flúor. Destacaram a importância de cirurgiões-dentistas conhecerem a concentração de flúor na água consumida pelas crianças, principalmente as que eram utilizadas no preparo de fórmulas de leites infantis.

VILLENA et al. (1996) analisaram 104 marcas comerciais de águas minerais adquiridas no mercado de vendas brasileiro no período de agosto de 1994 até fevereiro de 1996, sendo 96 nacionais (16 estados) e 8 estrangeiras (adquiridas no comércio do município de São Paulo-SP). Apresentaram teores acima de 0,7 ppm de flúor 10,6\% delas, sendo duas no Estado de São Paulo (1,36 ppm e 1,98 ppm), uma em Santa Catarina (1,02 ppm), uma no Paraná (0,92 ppm), quatro no Rio Grande do Sul (0,87 ppm; 1,69 ppm; 1,66 ppm e 4,44 ppm) e duas de origem estrangeira (argentina com 1,89 ppm e portuguesa com 3,16 ppm).

Com base nesses resultados, consideraram necessário maior controle nas águas minerais industrializadas no Brasil, com o propósito de prevenir a eventual ocorrência de fluorose dentária. Exemplificaram, com base na dose máxima de flúor que deve ser ingerida diariamente $(0,05$ a 0,07 mg F/kg), que a ingestão de pouco menos de meio copo de água por dia (158 ml) como a encontrada no Rio Grande do Sul (4,44 ppm de flúor), por uma criança de $10 \mathrm{~kg}$, seria suficiente para a intoxicação crônica. Segundo os autores, águas com teores elevados de flúor deveriam ser contra-indicadas 
para crianças menores de 7 anos de idade, o que deveria constar do rótulo padronizado do produto (concentração em ppm F - flúor iônico ou solúvel).

\subsubsection{Gestação e fatores relacionados}

Informações sobre a duração da gestação e o peso ao nascer da criança também têm sido investigadas para avaliação de associação à prevalência de fluorose dentária, pois podem indicar exposição a produtos fluoretados em idades precoces ou a doses de risco em função do peso.

WANG et al. (1997) observaram 383 crianças de 8 anos de idade em Asker (oeste de Oslo, Noruega), suprida por duas fontes de água de abastecimento $(0,05$ e $0,10 \mathrm{ppm}$ de $\mathrm{F})$, com o objetivo de conhecer a prevalência de fluorose dentária e relacioná-la com a exposição a fontes de flúor (suplementos e dentifrícios). Entre as informações coletadas, constava o peso ao nascer que, na análise de regressão logística não apresentou associação estatística significativa com a prevalência de fluorose dentária $(\mathrm{OR}=1,03 ; \mathrm{IC}=0,99-1,06)$.

OSUJI et al. (1988) em um estudo do tipo caso-controle, realizado em Borough of East York (1 ppm de F) na região metropolitana de Toronto (Canadá), investigaram, entre outros fatores, o parto prematuro e o baixo peso ao nascer. Dos 82 casos e 95 controles houve um freqüência de apenas 5\% na condição de parto prematuro e $6 \%$ na condição de baixo peso ao nascer, freqüência muita baixa para um razoável poder do teste de associação.

BARDSEN et al. (1999), na pesquisa realizada no oeste da Noruega, com 113 pessoas de 5 a 18 anos de idade que consumiram com durante toda a sua vida água com teores de flúor maiores ou iguais a 0,5 ppm. Estas foram comparadas com um grupo $(n=105)$ do mesmo distrito que consumiu água com teores de flúor menores que 0,1 ppm. Entre as variáveis observadas, foi estabelecida a correlação entre os graus de fluorose e o baixo peso ao nascer, obtendo-se uma fraca correlação $\left(r_{s}=-0,25 ; p<0,05\right)$. 


\subsubsection{Aleitamento}

O aleitamento materno exclusivo tem sido relatado como um fator de proteção para a ocorrência de fluorose dentária, pois indica a exposição tardia a outras fontes de flúor.

EKSTRAND et al. (1984) demonstraram embora fossem administradas altas doses de flúor para as mães $(11,25 \mathrm{mg})$, as crianças receberiam a partir do leite materno uma dose correspondente a $0,2 \%$ do que foi administrado à mãe (em torno de $30 \mu \mathrm{g} F /$ dia).

OPINYA et al. (1991) no estudo realizado em Nairobi (Kênia), local com alto teor de flúor na água (9 ppm), com 27 mulheres tiveram o objetivo de quantificar o total de flúor ingerido em 24 horas a partir de alimentos e bebidas, e determinar a correspondência dessa ingestão com os teores de flúor no leite materno. A média de ingestão de flúor foi de 22,1 mg (9,5-37,2 mg). O nível médio de flúor no leite materno foi de $0,033 \mathrm{mg} / \mathrm{l}(0,011-0,073$ $\mathrm{mg} / \mathrm{l})$ e não houve correlação estatisticamente significativa com o total de flúor ingerido.

Na pesquisa de VILLA et al. (1998) citada no item 2.2.1 (Tipo de água ingerida) realizada em San Felipe (Chile), com teores médios de flúor de 0,93 ppm, foi observado que o aleitamento materno exclusivo no grupo de crianças que sempre viveu no local, teve um efeito protetor $(O R=0,86$; IC $=0,75-0,98$ ).

BROTHWELL e LIMEBACK (1999) determinaram a prevalência de fluorose dentária e sua associação com fatores de risco, em um grupo de escolares da zona rural de uma área não fluoretada em Ontario (Canadá). Dos 1.367 escolares que tinham os incisivos centrais superiores irrompidos, houve resposta de 752 questionários enviados. No caso de crianças que residiam no local há quatro anos ou mais, entre os fatores que tiveram efeito independente significativo, encontrava-se a duração do aleitamento materno. 


\subsubsection{Chás}

O consumo de alguns tipos de chás tem sido investigado em populações que têm esse hábito como conseqüência de questões culturais, mas também pelo tipo de água utilizada no seu preparo.

Há duas variedades de chás (SANTORO 1997):

- variedade da China (Sinensis): de folhas pequenas, cultivada também no Japão, mais utilizada na fabricação do chá verde;

- variedade da região de Assam (Assamica), de folhas maiores, cultivada principalmente na Índia, Sri Lanka, Indonésia e áfrica e mais apropriada à fabricação do chá preto.

A quantidade de flúor nos chás está associada ao seu processamento, à forma de preparo da infusão e às condições climáticas e geográficas do local onde a planta cresceu; tais como altitude, tipo de solo, grau de insolação, chuvas e fontes de água disponíveis para 0 desenvolvimento da planta, bem como a sua variedade botânica. A Cammellia sinensis teria condições de retirar o flúor do solo e concentrá-lo em suas folhas por difusão passiva, o que tornaria o chá uma fonte natural de flúor (SANTORO 1997).

CURY (1981), embora considerando que o consumo de chás não se constituía em hábito no Brasil, que não havia referências em relação ao teor de flúor no mate, e que nos chás pretos nacionais esse teor era inferior ao dos importados, buscou identificar a concentração de flúor em três marcas comerciais de chá mate, no chimarrão gaúcho, em quatro marcas comerciais nacionais de chá preto, no erva doce, no Ban chá, e em duas marcas comerciais inglesas de chá preto. Observou que os teores de flúor eram muito baixos nos chás mates e na erva doce (menor que 3,0 ppm e, diluídos em água com 1 ppm de flúor, em torno de 0,2 ppm). Nos chás pretos a concentração de flúor variou de 104,0 a 204,8ppm e, diluídos em água com 1 ppm de flúor, variou de 0,430 a 0,671 ppm. Sua preocupação foi avaliar o efeito preventivo dos chás em relação à cárie dentária, mas destacou que se fossem preparados com água fluoretada (1 ppm), a quantidade de flúor 
ingerida a partir de uma xícara dos chás pretos seria de 0,484 mg, o que não representaria risco para a faixa etária de 2 a 3 anos.

Em relação ao Ban chá (chá verde macrobiótico), formulou duas explicações para a alta concentração de flúor, visto que não conhecia a identidade botânica do mesmo: ser mais uma planta com capacidade de concentrar flúor em suas folhas como a Cammellia sinensis, ou ser simplesmente folhas verdes da Cammellia sinensis. Concluiu reforçando o papel preventivo para cárie dentária dos chás pretos, mas destacou 0 desconhecimento sobre seu consumo no Brasil. Sobre o seu aproveitamento biológico, se o seu consumo fosse terapêutico, destacou o trabalho de Campos (1953, p. 138), que demonstrou que a quantidade de fluoreto fixado nos ossos de ratos devido ao consumo de chá era somente $7 \%$ menor do que se esperaria, em caso de se consumir água fluoretada na mesma concentração.

O interesse em relação ao efeito do mate e dos chás na prevenção da cárie dentária, também foi tema do trabalho realizado por LEE et al. (1986), com ratos alimentados com ração cariogênica. Estes foram divididos em cinco grupos: I - controle, submetido à água destilada; II - submetido à água destilada com 5 ppm de flúor; III - submetido à infusão de erva mate; IV submetido à infusão de chá preto e V - submetido à infusão de chá verde. Concluíram que os tratamentos não foram eficazes para reduzir a incidência da cárie em esmalte a um nível de significância, mas o grupo do flúor mostrou menos cáries que os grupos das infusões. O flúor, o mate e os chás verde e preto reduziram a incidência de cárie em dentina. A evolução do processo carioso foi atenuada com o mate e outros chás, independente do conteúdo de flúor em suas composições.

HEINTZE e BASTOS (1996) analisaram o teor de flúor e pH de 61 bebidas consumidas por brasileiros (refrigerantes tipo cola, guaraná, limão e laranja, sucos, leite in natura, leite em pó, águas minerais, chá mate e chá preto). Observaram que, com exceção do chá preto e uma das águas 
minerais, todas as bebidas apresentaram concentração de flúor abaixo de 1 ppm.

SANTORO (1997), em sua dissertação de mestrado, verificou os teores de flúor em chás produzidos a partir da Cammellia sinensis e industrializados no Brasil. Foram estudados chás pretos, verdes e preparados a partir de infusões de chá preto, disponíveis no mercado. Observou que os chás pretos analisados apresentaram teores médios de 1,60 $( \pm 0,43)$ ppm, os chás verdes 0,95 $( \pm 0,49)$ ppm e as infusões de chá preto $10,61( \pm 0,18)$, com diferenças estatisticamente significativas (95\% de confiança).

GONINI (1999) no estudo citado (item 2.2.1 - Tipo de água ingerida), observou que $90,6 \%$ das crianças incluídas na amostra de sua pesquisa consumiram chás ou infusões de ervas (chá mate, chá preto, camomila, erva cidreira, erva doce ou outros), porém não identificou associação estatisticamente significativa entre o consumo de chás no primeiro ano de vida e a presença de fluorose dentária.

CAO et al. (2000) buscaram identificar a concentração de flúor na água, solo, combustível, grãos, alimentos, vegetais e chás produzidos pela população tibetana, residente em terras com diferentes tipos de características ecológicas no Tibet. Observaram que a concentração média de flúor na água era de $0,06 \mathrm{~m} / \mathrm{l}$; o nível de flúor dissolvido no solo era 0,45 $\mathrm{mg} / \mathrm{kg}$; a concentração de flúor nos principais combustíveis era 0,10 mk/kg; nos principais grãos (cereais), alimentos e vegetais era $0,06-0,33 \mathrm{~m} / \mathrm{kg}$; no chá envazado e na mistura de Zanba com "tijolos de chá eram 3,09-3,61 $\mathrm{mg} / \mathrm{kg}$; e as concentrações de fluoretos resultantes na água, quando se preparava o chá com esses "tijolos" produzidos nas províncias de Sichuan e Yunan, eram de 533,89-617,32 mg/kg. Concluíram que o Tibet não era uma área com altos teores de flúor na água, solo ou ar a partir da poluição causada pela queima de óleo combustível. A alta exposição a flúor no Tibet era proveniente do consumo de comidas e bebidas (envazadas e Zanba) 
contendo "tijolos de chá", o que permitiria considerar o Tibet como uma área de risco para fluorose associada com essa bebida.

BUZALAF et al. (2002) avaliaram os teores de flúor em: A - 12 infusões de chá preto (Cammellia sinensis), B - 15 chás prontos para beber, C - 10 sucos em pó, D - 3 sucos que continham chá em pó e E - 4 sucos prontos para beber encontrados no Brasil. As médias de concentrações de flúor foram: A - 2,57 (1,07-3,99) ppm; B - 0,37 (0,08-0,81) ppm; C - 0,02 (00,03) ppm; 1,10 (0,99-1,22) ppm; 0,30 (0,12-0,52) ppm. Todas as amostras de infusões de chá preto, duas amostras de chás prontos para beber e todas as amostras de sucos que continham chá em pó apresentaram concentrações de flúor maiores que 0,7 ppm. Concluíram que alguns produtos analisados poderiam contribuir na dose diária de flúor ingerido, que seu consumo por crianças em idade de risco para fluorose dentária deveria ser evitado, e que o teor de flúor nesses produtos deveria ser informado nos rótulos.

HAYACIBARA et al. (2004) identificaram a concentração de flúor e alumínio em chás de ervas, chá preto, bebidas prontas para beber e chás importados consumidos no Brasil, considerando o risco que o flúor e o alumínio poderiam levar à saúde bucal e à saúde geral respectivamente. Observaram que os níveis de flúor nos chás de ervas eram muito baixos $(0,0025 \pm 0,0010 \mathrm{mg}$ por saquinho de chá mate), mas altos teores foram encontrados nos chás pretos (até 0,34 \pm 0,032 mg por saquinho de chás nacionais e até $0,33 \pm 0,146 \mathrm{mg}$ por saquinho nos importados). Nas bebidas prontas para beber esses teores chegaram a 1, $58 \pm 0,152 \mathrm{mg}$ por unidade de $340 \mathrm{ml}$. Considerando a dose de 0,07 mg F/kg/dia como o máximo de flúor a ser ingerido para evitar fluorose dentária, concluíram que alguns chás poderiam exceder a dose limite para crianças.

\subsubsection{Peixes}

Muitos estudos estabeleceram o chá e alimentos marinhos como fontes ricas em flúor. Esses alimentos contribuiriam com o flúor na dieta, 
cuja necessidade foi considerada na ordem de 2,5 mg F/kg para garantir um crescimento ótimo (SCHWARRZ 1974).

A literatura encontrada com relação à concentração de flúor em peixes e outros produtos pesqueiros é vaga e relativamente antiga. Muitos autores basearam seus trabalhos nas mesmas fontes e, portanto, as informações são muito repetitivas, os que partiram para novas análises nem sempre chegaram a valores de referência.

NETTLETON (1944) fez considerações sobre a quantidade de flúor em alimentos marinhos, onde relatou que o bacalhau e o hadoque possuíam concentração moderada de flúor. Salmão e arenque possuíam concentração maior que o bacalhau, enquanto crustáceos (camarão, ostras e caranguejos) possuíam concentração muito baixa deste elemento. Considerou ainda que os mexilhões eram alimentos ricos em flúor e também as sardinhas processadas (enlatadas).

Em uma revisão de literatura, CAUSERET (1962) observou que a carne de pescados marinhos continha geralmente $0,5 \mathrm{mg}$ a $1,0 \mathrm{mg}$ de F/100g, que o esqueleto era mais rico em flúor que a pele, e que espécies marinhas possuíam uma concentração de flúor maior que peixes de água doce.

HEMENS e WARWICK (1972) realizaram experimento para avaliar a influência que a concentração de flúor no ambiente aquático exerceria sobre algumas espécies. Concluíram que na curta exposição (96h) às altas concentrações não foram observados efeitos tóxicos nos organismos analisados. Já na longa exposição (72 dias), mexilhões e crustáceos apresentaram aumento na mortalidade e deterioração nas condições físicas e no processo reprodutivo. As quatro espécies estudadas (peixes, mexilhões, camarões e caranguejos) apresentaram acúmulo evidente de flúor em seus tecidos. Esse acúmulo ocorreu devido à alta concentração de flúor no meio e não da alimentação pois não houve um acúmulo significativo na flora ingerida pelas amostras. 
SOEVIK e BRAEKKAN (1979) avaliaram a quantidade de flúor no krill (Euphausia superba e Meganyctiphanes norvegica) pois, considerando sua abundância, poderia ser uma fonte potencial de flúor na alimentação humana. Observaram no experimento onde utilizaram aves, que não existia diferença significativa na retenção do flúor das amostras alimentadas com o krill quando comparadas com as expostas ao fluoreto de sódio, o que disponibilizaria seu consumo. Porém na avaliação da proteína concentrada, os valores encontrados excederam em até 24 vezes a quantidade máxima permitida pela FDA (Food and Drug Administration) que é de $100 \mathrm{mg} / \mathrm{Kg}$ (proporcionalmente ao fluoreto de sódio).

Ao avaliar os efeitos das altas concentrações de flúor no meio sobre algumas espécies de fitoplancton (primeiro nível da cadeia alimentar marinha), ANTIA e KLUT (1981) concluíram que estas espécies desenvolveriam tolerância ao flúor, quando a concentração fosse aumentada gradualmente e discutiram este fato fazendo uma análise de que, uma vez que o fitoplancton poderia desenvolver tolerância (sobreviver mesmo em ambientes com altas concentrações de flúor), a bioacumulação deste elemento deveria ser considerada; já que poderia acarretar injúrias para os seres que destes se alimentavam e para os outros níveis da cadeia alimentar marinha.

OEHLENSCHLÄGER e MANTHE (1982) identificaram a concentração de flúor em peixes e outros seres marinhos capturados na llha Elefante (Antártida) e concluíram que das seis espécies analisadas a concentração de flúor nos músculos era pequena, variando de 1,3-3,7 mg/Kg (valores não muito diferentes de espécies de outras regiões). No tecido ósseo foi detectada a concentração de 616-1207 mg/Kg (peso molhado da amostra) e as concentrações excediam no krill. Os autores comentaram a necessidade de maiores investigações, pensando em uma análise dos diversos níveis da cadeia alimentar, idade das espécies analisadas e influência do meio na absorção deste elemento. 
NELL e LIVANOS (1988) avaliaram os efeitos da concentração de flúor no meio para o crescimento e acumulação de flúor em espécies de ostras. Concluíram que a acumulação de flúor nestes animais tinha maior efeito quando sua concentração no meio era aumentada. Consideraram que, sendo o flúor tóxico (em concentrações elevadas) para o ser humano, o aumento de sua concentração em espécies consumidas pelos humanos era indesejável e deveria ser avaliada.

CAMARGO e TARAZONA (1991) realizaram experimento com trutas para avaliar a toxicidade do flúor em água doce, destacaram a maior tolerância das espécies marinhas ao flúor, já que este meio possuía naturalmente uma concentração do elemento variando de 1,2 a 1,4 ppm.

GIKUNJU (1992) buscou avaliar a concentração de flúor na tilápia do Lago Naivasha (Kenia). O autor relatou um quadro de fluorose dentária endêmica (30-50\% da população afetada) e procurou relacionar este quadro com 0 alto consumo de peixes e produtos pesqueiros pela população local. A concentração de flúor no lago era de 2,4-2,6 mg F/l, e o autor não estabeleceu a relação entre o flúor acumulado pela espécie analisada e o quadro severo de fluorose dentária na área.

MALDE et al. (1997) procurando uma explicação para fluorose endêmica de uma região africana, avaliaram a concentração de flúor em alimentos selecionados de cinco áreas próximas. Os autores deram ênfase na análise desta concentração nos peixes já que esta era uma fonte de proteína barata e muito consumida. Concluíram que a concentração de flúor no peixe inteiro era muito maior do que somente na carne, porém a quantidade absorvida pelo humano em cada uma das situações não era diferente e recomendaram maiores estudos nesta área.

\subsection{6. Água para preparo de alimentos}

A preocupação não somente com água ingerida, mas também com a utilizada no preparo de alimentos, foi um aspecto citado por DEAN et al. (1935) em suas investigações nas regiões com diferentes teores de flúor nos Estados Unidos. Também foi citada por GRIMALDO et al. (1995) como uma 
importante fonte de exposição a flúor no estudo realizado em San Luis Potosi (México), pois observaram que 92\% das 201 crianças selecionadas para o estudo (nasceram no local e sempre tiveram o mesmo endereço residencial), utilizavam a água de abastecimento público para o preparo e para reconstituição de alimentos e estavam expostas a mais altos níveis de flúor do que o normal.

A utilização de água para o preparo de alimentos infantis (aleitamento com utilização de fórmulas infantis, sucos, outras bebidas, alimentos infantis, cereais) tem sido apontada fator de risco para fluorose dentária, quando se estabelece relação com o peso da criança a dose de risco de ingestão de flúor. TOUMBA e CURZON (1994), no trabalho citado (item 2.2.1 - Água para ingestão), com águas engarrafadas comercializadas no Reino Unido, destacaram a importância de cirurgiões-dentistas conhecerem a concentração de flúor na água consumida pelas crianças, principalmente as que eram utilizadas no preparo de fórmulas de leites infantis.

LEVY et al. (1995ª) observaram 192 mães de recém-nascidos em dois hospitais de lowa City (lowa, Estados Unidos). As mães responderam questionário sobre a ingestão diária de alimentos e bebidas por seus filhos nas idades de seis semanas, três, seis e nove meses. Foi feita uma estimativa da quantidade média de água ingerida a partir de cada tipo de alimento, em cada um dos períodos, e foi estabelecida a relação com o peso das crianças e a dose ótima de ingestão de flúor com base no limite superior da dose atribuída para intoxicação crônica (0,05-0,07 mg F/kg). Observaram que a quantidade de flúor ingerido, a partir do total de formas utilizadas, excedeu a dose ótima de flúor para mais de $10 \%$ das crianças em cada um dos quatro grupos etários.

HEILMAN et al. (1997) avaliaram as concentrações de flúor em 206 marcas comerciais de alimentos infantis prontos para ingerir e 32 cereais infantis manufaturados, produzidos por duas companhias de quatro grandes cadeias de supermercados de lowa City, Yowa (Estados Unidos). Entre outras conclusões, destacaram que a água utilizada na reconstituição dos cereais era o maior determinante dos níveis de flúor. 
Pelas expressões em inglês empregadas na literatura, de um ponto de vista mais estrito, certas distinções podem ser identificadas. Tem sido documentado dois tipos básicos de emprego: (1) água para preparo de alimentos e (2) água adicionada para sucos e bebidas e para reconstituição de fórmulas infantis. No caso do primeiro tipo de uso, admite-se que pode envolver cozimento enquanto no segundo tipo, no caso de papinhas, mingaus e achocolatados, a água pode ser submetida à aquecimento. De todo modo, como o tempo de preparo é curto, pode-se considerar que a água tem seu efeito diretamente relacionado ao seu teor de flúor e não ao modo como entram em contato com os demais produtos. Assim, do ponto de vista prático é provável que essas pequenas diferenças não sejam clinicamente relevantes.

\subsubsection{Recipiente utilizado para o preparo de alimentos}

Em relação ao preparo dos alimentos, o tipo de recipiente utilizado pode ter influência na quantidade de flúor retida ao final do cozimento. FULL e PARKINS (1975) destacaram que a evaporação que ocorre com o cozimento é uma fonte potencial de maior concentração de flúor em soluções, e que o material do recipiente utilizado pode ter efeito na concentração de flúor da água usada no preparo dos alimentos. Destacaram que vários metais formariam compostos insolúveis de flúor. Recipientes refratários de vidro poderiam absorver flúor em sua superfície, enquanto que o revestimento anti-aderente poderia alterar o efeito estrutural do material do recipiente. Realizaram um trabalho com quatro tipos de recipientes: alumínio, aço inox, vidro refratário e anti-aderente, sendo que o teor de flúor na água do local havia sido estudado previamente pelos autores. As alterações na quantidade de flúor incorporada nos alimentos foi observada nos quatro tipos de recipientes. Quando não houve interação do flúor com a superfície do recipiente, o resultado da evaporação da água durante o cozimento poderia ser um aumento da concentração de flúor. Este efeito foi predominante com o recipiente anti-aderente. Tanto a absorção quanto a formação de compostos insolúveis poderiam baixar os níveis de flúor. $O$ 
recipiente de alumínio, comparado com os de aço inox e vidro refratário, aparentou remover o flúor, com a formação de fluoreto de alumínio.

TENNAKONE e WICKRAMANAYAKE (1987) conduziram um experimento para estimar a taxa de separação de liberação de alumínio do recipiente utilizado, em diferentes situações de cozimento de alimentos e suas respectivas concentrações de flúor. Na fervura de água com teor de flúor de 1 ppm, tratada com ácido cítrico $(\mathrm{pH} 3$, semelhante ao das condições de cozimento) houve uma liberação de aproximadamente 200 ppm de alumínio em 10 minutos enquanto que na ausência de flúor foi de 0,2 ppm. O cozimento prolongado produziu uma concentração de aproximadamente 600 ppm, influenciada pela maior superfície de contato da água com o recipiente. A taxa de dissolução foi $\mathrm{pH}$ dependente com um mínimo em pH neutro. Tomates triturados (50 g em $250 \mathrm{ml}$ ) cozidos no mesmo tipo de recipiente com água com 1 ppm de flúor produziram uma concentração de alumínio de aproximadamente 150 ppm. A água consumida em alguns locais continha 10 ppm de flúor ou mais e o cozimento ou a conservação prolongada em recipiente de alumínio de alimentos contendo grandes quantidades de flúor (500 ppm em chás, 100-700 ppm em peixes) poderia liberar mais de 100 ppm de alumínio. Concluíram que a taxa de liberação de alumínio de utensílios foi aumentada na presença de flúor e que a resistência do alumínio à corrosão em solução alcalina ou suavemente ácida dependia da formação de um filme inerte de óxido. A corrosão na presença de flúor resultaria de uma permeabilidade do filme de óxido ao íon flúor.

RIBEIRO (1992) realizou um trabalho com o objetivo de conhecer a concentração de flúor na água (teor de 0,971 ppm e controle com 0,075 ppm) quando fervida e mantida em seu ponto de ebulição, utilizando três tipos de recipientes usados no preparo de alimentos: alumínio delgado (1,5 $\mathrm{mm}$ de espessura), alumínio espesso (3,3 $\mathrm{mm}$ de espessura) e aço inox, sendo que os dois primeiros não tiveram cobertura. Destacou que, após ferver e ser mantida em ebulição, a água concentra flúor, cujos teores vão aumentando com a evaporação, de forma diretamente proporcional à 
rapidez da evaporação. Porém, o tempo de manutenção da água em ebulição utilizado na pesquisa foi bem maior do que o normalmente usado. Concluiu que a água ao ferver, mantém o mesmo teor de flúor que a água não fervida, e que a concentração de flúor ocorre independente do material do recipiente utilizado; com destaque para o recipiente de aço inox (concentração 66 vezes maior que a inicial quando comparada com 0 recipiente de alumínio delgado), o que mereceria estudos posteriores em relação ao fato de o alumínio "complexar" ( ${ }^{*}$ o flúor.

\subsubsection{Hábitos alimentares}

Além dos chás e peixes, outros hábitos também foram identificados como fatores associados à fluorose dentária. Entre eles foram citados: consumo de sucos artificiais, consumo de alimentos e fórmulas infantis e bebidas. OSUJI et al. (1988), no estudo citado (item 2.2.2 - Gestação e fatores relacionados), realizado na região metropolitana de Toronto (Canadá), investigaram, entre outros fatores, a ingestão diária de peixes, de fórmulas infantis e de bebidas leves. As freqüências de $14 \%$ de ingestão diária de peixes, de $18 \%$ de consumo de fórmulas infantis e de 19\% de bebidas leves, não apresentaram associação estatística significativa com a presença de fluorose dentária.

CHAN et al. (1990) destacaram que, baseado no aumento do consumo de chá, café e outras bebidas contendo cafeína por crianças, e no efeito da cafeína na biodisponibilidade do flúor, a incidência de fluorose dentária poderia ser atribuída à substituição da ingestão de água por esses tipos de bebidas. Observaram que a ingestão simultânea de flúor e cafeína, ou de bebidas contendo cafeína, como chá, café e bebidas tipo cola, resultaram em uma maior disponibilidade de flúor, quando sua concentração era medida no plasma.

$\left(^{*}\right)$ "Complexar" significa formar várias ligações químicas entre o "complexante" e a substância "complexada", formando um complexo solúvel entre os dois. Assim, o alumínio $\left(\mathrm{A}^{+3}\right)$ tem alta afinidade pelo flúor $\left(\mathrm{F}^{-1}\right)$, "complexando-o". O flúor sai da solução e passa a fazer parte do complexo fluoreto de alumínio $\left(\mathrm{AlF}_{3}\right)$.

Informação fornecida via correio eletrônico pelo Prof. Jaime A. Cury, da Faculdade de Odontologia da Universidade Estadual de Campinas - UNICAMP, no dia 27/01/2005. 
Além disso, destacaram o estudo de Hargreaves (1988, p. 22) realizado no Canadá, que apontou que o consumo diário, por crianças, de bebidas carbonatadas, de chá e de café, tinham sido respectivamente de $2.600 \mathrm{ml}, 1.300 \mathrm{ml}$ e $1.800 \mathrm{ml}$.

PANG et al. (1992) observaram famílias de crianças de 2 a 10 anos de idade de North Carolina (Estados Unidos), com o objetivo de identificar a quantidade ingerida de flúor a partir do consumo de bebidas. As informações foram coletadas por meio de questionário que incluiu também informações demográficas. As médias de flúor ingerido foram de 0,36 $\mathrm{mg}$ pelas crianças de 2 a 3 anos de idade, de 0,54 mg pelas crianças de 4 a 6 anos de idade e de $0,60 \mathrm{mg}$ pelas crianças de 7 a 10 anos de idade.

WINKLE et al. (1995) realizaram um estudo longitudinal com mães de recém-nascidos em oito hospitais do centro e leste de lowa (Estados Unidos). Os questionários levantaram informações sobre alimentos e bebidas diárias, suplementos fluoretados, uso de dentifrício e tipo de água consumida. As informações foram obtidas quando as crianças tinham seis semanas, três meses e sempre a cada três meses. Quando as crianças tinham 3 a 4 anos de idade, foram examinadas em relação à cárie e fluorose dentária. Observaram que os teores de flúor nas comidas prontas foram de 0,17 ppm, nos leites líquidos concentrados de 0,12 ppm e nos leites em pó concentrados de 0,14 ppm. Nos produtos à base de soja, essas médias foram: comidas prontas 0,30 ppm, líquidos concentrados 0,24 ppm e pósconcentrados 0,24 ppm. Concluíram que a avaliação da necessidade de suplementação de flúor por fórmulas infantis era difícil, porque dependia tanto do tipo de fórmula utilizado, quanto do teor de flúor na água de preparo. Também observaram que o uso de sistemas de filtragem da água utilizada no preparo das fórmulas em pó não interferiu nos níveis de flúor.

MABELYA et al. (1997) identificaram a contribuição do magadi (mineral de sabor alcalino, utilizado para reduzir o tempo de cozimento e dar mais sabor aos alimentos), adicionado no preparo de certas verduras e vagens, na prevalência e severidade da fluorose dentária nos distritos de 
Pangani e Muheza (áreas litorâneas da região de Tanga) e Singida e Iramba (interior, a $1.500 \mathrm{~m}$ de altitude), situados na Tanzânia. Foram examinados 1.566 escolares de 12 a 17 anos de idade, que tinham nascido e morado nos locais e foi coletada a história da dieta. Também foram medidos os teores de flúor no magadi e excreção de flúor pela urina. Nas regiões onde a dieta era baseada em chá e peixe marítimo, a prevalência de fluorose variou de $7 \%$ a $46 \%$, com casos raros de fluorose dentária severa. Ao contrário, nas regiões onde havia o consumo do magadi, a prevalência de fluorose dentária variou de $53 \%$ a $100 \%$, com proporções de fluorose severa que variaram de $18 \%$ a $97 \%$. Concluíram que os dados de prevalência de fluorose dentária indicavam grande evidência de que o consumo do magadi era o maior determinante da prevalência e severidade do agravo naquelas regiões.

HEILMAN et al. (1997) no estudo citado (item 2.2.6 - Água para preparo de alimentos), avaliaram as concentrações de flúor em 206 marcas comerciais de alimentos infantis prontos para ingerir e 32 cereais infantis consumidos em lowa City, lowa (Estados Unidos). Entre os alimentos prontos para ingerir, os teores de flúor variaram de 0,01 a $8,38 \mu \mathrm{g} \mathrm{F} / \mathrm{kg}$. Alimentos compostos de galinha tiveram os maiores teores $(1,05 \mathrm{a} 8,38 \mu \mathrm{g}$ $\mathrm{F} / \mathrm{kg}$ ), enquanto os de carne e os de peru variaram de 0,01 a $0,66 \mu \mathrm{g} \mathrm{F} / \mathrm{kg}$. Os alimentos compostos de frutas, as sobremesas, os alimentos mistos e os cereais variaram de 0,01 a 0,63 $\mu \mathrm{g} \mathrm{F} / \mathrm{kg}$. Em relação aos cereais infantis, houve variação entre caixas de uma mesma marca, como por exemplo em uma em que a concentração de flúor era $0,40 \mu \mathrm{g} \mathrm{F} / \mathrm{kg}$ e em outra $0,09 \mu \mathrm{g}$ $\mathrm{F} / \mathrm{kg}$. Concluíram recomendando a continuidade do monitoramento dos teores de flúor em alimentos infantis, especialmente nos produtos derivados de aves do tipo galinácea.

TURNER et al. (1998) avaliaram a concentração de flúor em bebidas carbonatadas e sucos obtidos de duas comunidades americanas: Houston (com 0,69 ppm de flúor na água) e San Antonio (com 0,2 ppm de flúor na água) e qual o impacto da água de uma comunidade fluoretada em uma não fluoretada ("efeito halo"). Foram analisadas 24 bebidas carbonatadas e 22 sucos. A média dos teores de flúor nas bebidas carbonatadas de Houston foi 
$0,78( \pm 0,07) \mathrm{ppm}$ e das de San Antonio foi 0,33 $( \pm 0,28) \mathrm{ppm}$. Em relação aos sucos essas médias foram respectivamente $0,77( \pm 0,21)$ e $0,58( \pm 0,38) \mathrm{ppm}$ de flúor. Analisando os teores de flúor nas bebidas das duas comunidades, concluíram que o "efeito halo" mais provavelmente aumentou a exposição a flúor em San Antonio que tem águas não fluoretadas; do que diminuiu a exposição em Houston que tem água fluoretada. Isto sugeriu que o impacto do "efeito halo" foi maior em áreas não fluoretadas.

YODER et al. (1998) realizaram um estudo em escolas de três locais da Tanzânia, localizados em altitudes diferentes e com teores de flúor na água também distintos: 1 - Chanika School, no nível do mar e com baixos teores de flúor na água, 2 - Rundugai School a $840 \mathrm{~m}$ de altitude e com altos teores de flúor na água e 3 - Kibosho School a $1.463 \mathrm{~m}$ de altitude e com baixos teores de flúor na água. Coletaram informações sobre hábitos alimentares e avaliaram os teores de flúor nas refeições, na urina dos participantes, na água e no magadi. Os teores de flúor na água dos locais foram: 1 e $3=0,05( \pm 0,05) \mathrm{ppm}$ e 0,18 $( \pm 0,320 \mathrm{ppm})$ e, $2=5,72( \pm 4,71)$ ppm. Nos locais 1 e 3 as médias do TF foram $0,01( \pm 0,07)$ e $4,39( \pm 1,52)$. No local 2 a média foi $4,44( \pm 1,68)$. As médias das concentrações de flúor na urina foram: $1=0,52( \pm 0,70) \mathrm{ppm} ; 2=4,34( \pm 7,62) \mathrm{ppm}$; e $3=1,43( \pm 1,80)$ ppm. Nas refeições essas médias variaram de 0,01 a 22,4 ppm e no magadi foi de $83.211 \mathrm{ppm}$. Concluíram que a prevalência da fluorose no local 3 não era consistente com o teor de flúor na água e atribuíram a sua severidade, ao teor de flúor no magadi, a outros elementos encontrados no magadi e à nutrição deficiente a maior contribuição para a severidade da fluorose dentária. Acrescentaram que a altitude era uma variável que diferenciava os locais.

LOYOLA-RODRIGUEZ et al. (1998) realizaram um estudo para avaliar as concentrações de flúor em bebidas engarrafadas consumidas em San Luis Potosi (México). Foram avaliados refrescos comercializados em quatro estados diferentes, produzidos por empresas locais ou nacionais no país e sucos de frutas de onze sabores. Em relação aos refrescos observaram diferenças estatisticamente significativas entre diferentes 
produtos de companhias nacionais $(p<0,05)$ e entre as companhias locais e nacionais $(p<0,05)$. Os sucos de frutas apresentaram concentrações de flúor elevadas. Concluíram que a maioria das bebidas engarrafadas consumidas no local apresentaram níveis de flúor acima do estabelecido pela norma mexicana, e que poderiam ser um fator de risco adicional para fluorose dentária na população exposta.

HEILMAN et al. (1999) avaliaram a concentração de flúor de 332 bebidas leves carbonatadas (refrigerantes) consumidos em lowa City (lowa, Estados Unidos). Observaram que os teores variaram de 0,02 a 1,28 ppm de flúor, com média de 0,72 $( \pm 0,34) \mathrm{ppm}$ de flúor. Tomando como base o estudo de PANG (1992), calcularam que as crianças consomem em torno de $40 \%$ de líquido a partir do leite e os outros $60 \%$ são provenientes de outros tipos de bebidas. Concluíram apontando que médicos e cirurgiões-dentistas devem estar atentos ao prescrever suplementos fluoretados em locais com baixos teores de flúor na água por conta do consumo substancial dessas bebidas. Destacaram que embora essas bebidas pudessem conter teores adequados de flúor, raramente isso era informado pelos fabricantes.

AWADIA et al. (1999) compararam a prevalência e severidade da fluorose dentária (TF) entre 165 crianças e adolescentes vegetarianos e nãovegetarianos de cinco escolas de Arusha (Tanzânia). No grupo vegetariano ( $n=24)$, a prevalência de fluorose dentária foi de $67 \%$, sendo $21 \%$ com fluorose severa. No grupo não-vegetariano a prevalência de fluorose dentária foi de $95 \%$, sendo $35 \%$ com fluorose severa. Na análise univariada, a idade, o vegetarianismo e uma série de outros fatores relatados na dieta (número de refeições diárias, consumo de mingaus preparados em casa, consumo de peixes, entre outros) apresentaram associação estatística significativa com a prevalência de fluorose dentária $(p<0,05)$. A análise de regressão logística múltipla mostrou que o risco de desenvolvimento de fluorose dentária foi sete vezes maior entre não vegetarianos do que em vegetarianos. Os autores concluíram que essa associação estava relacionada com o tipo de dieta. 
AWADIA et al. (2000), observaram fatores associados à severidade da fluorose dentária (TF) em duas áreas da Tanzânia (Moshi e Kibosho), com teores de flúor na água menores de 0,4 ppm. A prevalência de fluorose dentária em Moshi foi de 60\%, sendo 10\% de fluorose severa. Em Kibosho, a prevalência de fluorose dentária foi de $100 \%$, sendo $35 \%$ de fluorose severa. Relataram que o uso do magadi era uma prática comum no norte da Tanzânia, introduzida na alimentação na idade de sete meses.

Em Moshi, a era comum a alimentação infantil com um mingau líquido, denominado lishe, à base de vagem, amendoim e sardinha. Em Kibosho, era comum um mingau denominado kiborou, uma mistura de vagem e bananas cozidas com magadi. Observaram que em Moshi $65 \%$ das crianças consumiam o magadi e em Kisongo essa proporção era de $97 \%$. Em Moshi, o risco para a ocorrência de fluorose dentária entre as crianças que usavam magadi foi significativamente maior $(\mathrm{OR}=5)$. Em Kibosho, o risco para a ocorrência de fluorose dentária severa, foi maior $(\mathrm{OR}=3)$ entre as crianças que consumiam riborou (com magadl), quando comparadas com as que consumiam lishe (sem magadi). Concluíram que a prevalência e severidade da flurose dentária era explicada pela exposição a flúor a partir do magadi.

BUZALAF et al. (2003), apontaram que chocolates em barra e bolachas de chocolate são guloseimas altamente apreciadas pelas crianças e que, na possibilidade de conterem flúor, associado a seu excessivo consumo poderiam contribuir para a ingestão diária de flúor e participar no estabelecimento da fluorose dentária.

Avaliaram a concentração de flúor em doze tipos de chocolates em barra e recheios de chocolate de sete tipos de bolachas adquiridos em Bauru-SP. Observaram que a concentração de flúor nos chocolates em barra foi $0,30( \pm 0,45) \mu \mathrm{g} / \mathrm{g}$ e nos recheios das bolachas foi $1,08( \pm 2,64) \mu \mathrm{g} / \mathrm{g}$. Concluíram que alguns dos alimentos analisados poderiam ser importantes contribuintes para a ingestão diária de flúor. Destacaram que no caso do produto que apresentou a maior concentração $(7,06 \mu \mathrm{g} / \mathrm{g})$, se forem 
consumidas apenas três unidades uma vez ao dia, elas poderiam fornecer mais de $40 \%$ da dose diária máxima recomendada para uma criança de 2 anos de idade e que essa informação deveria constar no rótulo do produto.

Em estudo semelhante, CARDOSO et al. (2003) avaliaram os teores de flúor presentes em nove cereais e nove salgadinhos adquiridos em Bauru-SP. Observaram que a concentração de flúor nos cereais foi 0,76 $( \pm 0,60) \mu \mathrm{g} / \mathrm{g}$ e, nos salgadinhos, 0,32 $( \pm 0,09) \mu \mathrm{g} / \mathrm{g}$. Os resultados sugeriram que a quantidade de flúor em alguns dos produtos poderia contribuir para a ingestão diária total de flúor e, como no estudo anterior, recomendaram que os rótulos desses produtos deveriam conter essa informação.

\subsubsection{Bochechos e géis fluoretados}

A exposição a bochechos e géis fluoretados também foi mencionada em algumas pesquisas, porém com controvérsias entre os autores.

WEI e KANELLIS (1983) observaram dois grupos de crianças americanas, um com 98 crianças de lowa que não tinham experiência com bochechos fluoretados, e outro com 376 crianças da California (Estados Unidos) que vinham participando semanalmente de um programa de bochechos fluoretados por um período de oito meses. Teve o objetivo de determinar a quantidade de flúor retida após bochechos com solução de fluoreto de sódio, de forma a determinar as condições ótimas de indicação de bochechos fluoretados para pré-escolares: concentração de flúor, volume e duração.

Reconheceram a dificuldade em estabelecer uma clara relação entre a idade de realização dos bochechos, o volume de solução utilizada e a quantidade ingerida devido ao fato de que os subgrupos correspondiam a amostras de tamanho limitado. Porém, foi possível observar que crianças de 4 e 5 anos de idade ingeriram maior quantidade de solução à medida que aumentava o volume de solução. Crianças de 3 anos de idade ingeriram maior proporção $(6,9 \%)$ do total da solução quando comparadas com as de 4 e 5 anos de idade (valores respectivamente de 2,8\% e 1,8\%) 
SZPUNAR e BURT (1988) analisaram crianças de 6 a 12 anos de idade residentes em quatro áreas de Michigan (Estados Unidos) com teores de flúor na água nos seguintes valores: 0,0 ppm; 0,8 ppm; 1,0 ppm e 1,2 ppm. Os autores relataram que as crianças das quatro comunidades ingeriam quantidade semelhante de flúor a partir de dentifrícios, suplementações e aplicações profissionais, e atribuíram a ocorrência de fluorose nessa área ao fato de estarem submetidas a bochechos com soluções tópicas de flúor.

RIPA (1991) discutiu o papel de métodos tópicos de uso do flúor (dentifrícios, bochechos, aplicação profissional e auto-aplicação de gel) na redução da prevalência da cárie dentária e aumento da prevalência da fluorose dentária em comunidades dos Estados Unidos nos últimos 20 anos. O aumento da prevalência da fluorose dentária ocorreu nas formas leves (aceitáveis esteticamente) e foi mais observado, proporcionalmente, em comunidades com teores deficientes de flúor na água do que naquelas com teores ótimos ou acima. Em relação à ingestão de soluções de bochechos e géis fluoretados, segundo o autor, houve poucas evidências de sua participação no aumento da fluorose dentária.

Em relação à auto-aplicação de gel fluorado, STOOKEY (1994) destacou o trabalho de Bell et al. (1985; p.184), que observaram que crianças de 7 a 13 anos de idade não expectoravam $62 \%$ do gel utilizado na aplicação com escova, quantidade que provavelmente foi ingerida. Afirmou ainda que o trabalho de Bohaty et al. (1989; p.185) também sugeriu esse método como um fator de risco para fluorose dentária.

JOHNSTON (1994) reviu o efeito da aplicação tópica profissional de flúor e o risco em relação à sua ingestão. Embora existissem poucos estudos, havia evidências suficientes para a continuidade do seu uso, com cuidados para evitar sua ingestão, visto que o maior risco era de intoxicação aguda. Segundo o autor, a aplicação tópica profissional não representava risco para fluorose dentária. 
BROTHWELL e LIMEBACK (1999) no estudo realizado em Ontario no Canadá (citado no item 2.2.3 - Aleitamento), identificaram por meio de análise univariada associação estatisticamente significativa com a prevalência e severidade da fluorose dentária com o uso de soluções de bochechos $(p<0,001)$ e com a aplicação tópica profissional $(p<0,05)$. Na análise de regressão múltipla, dos dois fatores, apenas o uso de soluções para bochechos teve associação estatisticamente significativa ( $O R=2,73$; $\mathrm{IC}=1,06-7,05 ; \mathrm{p}=0,038)$.

Como a exposição a esses produtos acaba se dando, na maioria das vezes, a partir de uma dose única, não se pode desprezar os achados de BROGLIO (1994) em sua pesquisa com ratos expostos e não expostos a única dose de flúor. De modo geral, observou que o nível de flúor circulante, mesmo 16 dias após a administração da dose, poderia estar relacionado com distúrbios do desenvolvimento dental, o qual seria potencializado pela mobilização de flúor do osso adjacente.

\subsubsection{Dentifrícios fluoretados}

Os dentifrícios fluoretados têm sido apontados como fator associado para fluorose dentária em várias pesquisas e diversos aspectos têm sido destacados. Um deles estaria relacionado à idade de início da escovação.

PENDRYS et al. (1994) em uma pesquisa do tipo caso-controle com 401 adolescentes de seis comunidades de Connecticut (Estados Unidos), com teores adequados de flúor na água de abastecimento. Entre os fatores identificados no questionário, estava o período de escovação (nunca, do nascimento aos 8 anos de idade, de 3 a 8 anos de idade e outros períodos de exposição). Observaram que o uso precoce e contínuo de dentifrício fluoretado (do nascimento até 8 anos de idade) apresentou maior associação com a prevalência de fluorose dentária $(O R=2,80 ; I C=1,15-6,81)$, quando comparado com a não utilização.

PENDRYS et al. (1996) realizaram um estudo semelhante com 460 adolescentes de seis comunidades com água de abastecimento não 
fluoretada de Massachusets e Connecticut (Estados Unidos). Dentro da história da escovação dental foi identificado idade de início da escovação e freqüência diária (depois de dois anos de idade, uma vez ao dia e mais de uma vez ao dia; e entre 1 e 2 anos de idade, um vez ao dia e mais de uma vez ao dia). Observaram que o uso precoce e contínuo de dentifrício fluoretado (entre 1 e 2 anos de idade) apresentou maior associação à prevalência de fluorose dentária, quando comparado com o início após 2 anos de idade. A associação foi mais forte nos casos em que os dentes iniciaram a sua formação de 2 a 6 anos de idade ( $O R=4,23$; IC=1,72-10,41) em relação aos casos em que os dentes iniciaram a formação desde 0 nascimento até o primeiro ano de vida $(\mathrm{OR}=2,56 ; \mathrm{IC}=1,34-4,88)$.

A idade de início do uso do dentifrício também foi destacada por HOLT e MURRAY (1996), em uma revisão de literatura com o objetivo de rever os conhecimentos sobre dentifrícios fluoretados, para identificar problemas relacionados à sua efetividade, além de formular recomendações aos profissionais da saúde, fabricantes e autoridades sobre seu emprego. Concluíram que os fatores de risco para fluorose dentária poderiam ser hierarquizados, sendo que a idade de início do uso de dentifrícios ocuparia a segunda posição, superada apenas pelo uso inadequado de suplementos fluoretados.

CLARK e BERKOWITZ (1997) observaram crianças e adolescentes das cidades de Comox-Courtenay, Campbell River e Kamloops (British Columbia, Estados Unidos), com o objetivo de determinar a ocorrência de problemas estéticos decorrentes da fluorose dentária e relacioná-los a diferentes histórias de exposição ao flúor; verificando exposição à água fluoretada, suplementos e dentifrícios fluoretados. Observaram que $46 \%$ dos examinados apresentava fluorose dentária nos graus mais leves, sendo que $40 \%$ a apresentava nos dentes anteriores superiores. A análise de regressão logística demonstrou associação significativa com o uso de dentifrícios fluoretados durante os três primeiros anos de vida (OR=7,2; IC=1,09-47,47; $p=0,04)$. 
GONINI (1999) no estudo citado anteriormente (item 2.2.1 - Tipo de água ingerida), não encontrou diferenças estatisticamente significativas nas freqüências de fluorose dentária entre as 318 crianças cujas mães relataram realizar escovação com dentifrício antes dos 37 meses de idade; divididas em dois grupos: início até 24 meses e entre os 25 e 36 meses de idade. Levantou a possibilidade de o resultado ser atribuído ao fato de parte das crianças envolvidas na pesquisa ter utilizado dentifrícios sem flúor em sua composição.

RIPA (1991), na discussão citada (item 2.2.8 - Bochechos e géis fluoretados), identificou vários aspectos relacionados aos dentifrícios que deveriam constar de um guia de orientações, para promover cuidados relacionados aos hábitos de escovação por pré-escolares. Um dos itens sugeridos foi a utilização de escovas infantis, pois o tamanho da cabeça da escova poderia estimular a colocação de maior ou menor quantidade de dentifrício.

Em relação ao tipo de dentifrício utilizado, STOOKEY (1994) relatou que estudos sobre o papel dos dentifrícios na ocorrência da fluorose dentária tinham resultados conflitantes, mas que algumas conclusões eram comuns entre os autores como: não recomendação daqueles com altas concentrações de flúor (1.000-1.100 ppm) para crianças menores de 7 anos de idade, sugerindo esforços em relação à produção de dentifrícios com menores concentrações de flúor.

LEVY et al. $1995^{\mathrm{b}}$ em uma revisão de literatura sobre as diversas formas de ingestão de flúor (dieta, dentifrícios, suplementos e outras formas) destacaram que o uso de dentifrícios sem flúor em pré-escolares, não deve ser uma panacéia, pois elimina os benefícios pós-eruptivos considerados muito importantes na dentição decídua.

Em relação à freqüência diária de escovação, BARDSEN et al. (1999), em seu estudo na Noruega citado anteriormente (item 2.2.1 - Tipo de água ingerida), não observaram diferenças estatisticamente significativas na 
prevalência de fluorose dentária e o uso de dentifrício fluoretado até uma vez ao dia ou mais vezes.

Por outro lado, PENDRYS et al. (1996), em estudo nos Estados Unidos, identificaram a freqüência associada à idade de início da escovação e observaram que o uso precoce e contínuo de dentifrício fluoretado (mais de uma vez ao dia) apresentou maior associação à prevalência de fluorose dentária quando comparado com uma única vez. Encontraram associações nos casos em que os dentes iniciaram a formação desde o nascimento até o primeiro ano de vida $(\mathrm{OR}=2,56$; $\mathrm{IC}=1,34-4,88)$ e nos casos em que os dentes iniciaram a sua formação de 2 a 6 anos de idade $(O R=4,23 ; I C=1,72-10,41)$.

MASCARENHAS e BURT (1998) realizaram um estudo de casocontrole em Goa (Índia) com 1.189 crianças com média de idade de 12,2 anos. O objetivo do estudo foi quantificar o risco de ocorrência de fluorose dentária provocada pelo flúor presente nos dentifrícios em uma população cuja fonte de exposição ao halogênio era apenas o uso desse método. Foi observada a ocorrência de fluorose dentária em 12,9\% das crianças e foram enviados questionários para preenchimento pelos pais ou responsáveis. Os resultados da análise de regressão logística mostraram que o uso de dentifrícios antes dos 6 anos de idade foi um indicador de risco para fluorose dentária $(O R=1,83 ; I C=1,05-3,15)$. As crianças que iniciaram o uso de dentifrícios antes dos 2 anos de idade tiveram um aumento significativo da severidade da fluorose dentária $(\mathrm{OR}=1,37 ; \mathrm{IC}=0,92-2,02)$.

A execução da escovação, a supervisão da escovação e a colocação do dentifrício na escova por um responsável enquanto a criança não conhece os riscos do seu uso inadequado, têm sido apontadas como fatores de proteção para a ocorrência de fluorose dentária.

Na revisão de RIPA (1991), onde identificou vários aspectos relacionados aos dentifrícios que deveriam constar de um guia de orientações, para promover cuidados relacionados aos hábitos de escovação por pré-escolares, outros aspectos sugeridos foram relacionados a participação de pais/responsáveis: escovação dos dentes das crianças 
enquanto elas não tivessem habilidade; colocação do dentifrício na escova das crianças enquanto elas não tivessem conhecimento dos riscos e supervisão da escovação das crianças a partir da idade escolar.

LEVY et al. (1997) em seu estudo citado (item 2.2.6 - Água para preparo de alimentos), em lowa City (lowa, Estados Unidos) com mães de crianças recém-nascidas em dois hospitais, observaram que elas estavam sendo mais cuidadosas em relação à duração da escovação e vinham sendo as responsáveis pela sua execução.

A quantidade de dentifrício utilizada associada à quantidade ingerida também tem sido investigada em relação à sua associação com a ocorrência de fluorose dentária.

BARNHART et al. (1974) realizaram um estudo cujo protocolo simulava condições de uso doméstico do dentifrício e minimizava erros em relação às estimativas. Utilizava o método espectofotométrico, onde o marcador era o cloreto de lítio adicionado ao dentifrício. Foi realizado em Milford, Ohio (Estados Unidos) e envolveu quatro grupos etários: 2 a 4 anos de idade; 5 a 7 anos de idade; 11 a 13 anos de idade e 20 a 35 anos de idade. A média de dentifrício usada foi de $0,86 \mathrm{~g}$ a $1,39 \mathrm{~g}$ por escovação. Os valores médios ingeridos foram de 0,04 a $0,30 \mathrm{~g}$ por escovação, aumentando à medida que diminuiu a faixa etária. O percentual de dentifrício ingerido foi de $34,9 \%$ para o grupo de 2 a 4 anos de idade; $13,9 \%$ para 0 grupo de 5 a 7 anos de idade; $6,4 \%$ para o grupo de 11 a 13 anos de idade $e$ $2,9 \%$ para o grupo de 20 a 35 anos de idade.

EKSTRAND e EHRNEBO. (1980) estudaram a absorção de flúor em quatro voluntários jovens, comparando a concentração no plasma e na urina após a administração intravenosa de uma dose de $3 \mathrm{mg}$ de flúor e ingestão de $6 \mathrm{~g}(6 \mathrm{mg}$ de $\mathrm{F}$ ) de dois diferentes tipos de dentifrícios fluoretados (um com fluoreto de sódio - NAF e outro com com monoflúor-fosfato de sódio $\left.\mathrm{Na}_{2} \mathrm{PO}_{3} \mathrm{~F}\right)$ ) em três momentos diferentes. Encontraram concentrações plasmáticas de flúor a partir da ingestão do NAF de $111 \pm 13 \%$ e de $96 \pm$ $16 \%$ a partir da ingestão do $\mathrm{Na}_{2} \mathrm{PO}_{3} \mathrm{~F}$. Como a absorção de flúor a partir dos 
dentifrícios foi praticamente total, consideraram os dentifrícios fluoretados como um importante fator de exposição diária a flúor por crianças.

EKSTRAND et al. (1983) analisaram a concentração plasmática e a excreção urinária em cinco crianças de 3-4 anos de idade, após o uso de 0,6 $\mathrm{g}$ de dois dentifrícios com 1.000 ppm de $\mathrm{F}$ e 250 ppm de $F$, equivalentes respectivamente a $0,6 \mathrm{mg}$ de $\mathrm{F}$ e $0,15 \mathrm{mg}$ de $\mathrm{F}$. Os resultados mostraram níveis plasmáticos significativamente o uso de dentifrícios contendo 1.000 ppm de $\mathrm{F}$. Em relação à quantidade de flúor na urina, houve variações individuais, demonstrando a dificuldade de estabelecer parâmetros através desta medida. Os autores concluíram que a ingestão do flúor contido em dentifrícios com 1.000-1.500 ppm pode ser um aspecto importante a ser considerado quando se avaliam fatores de risco para fluorose dentária. Reforçaram ainda que, por esse motivo, programas de suplementação de flúor vinham sendo reconsiderados e, em muitos países doses mais restritas vinham sendo recomendadas.

SIMARD et al. (1989) realizaram um estudo piloto com 23 crianças de um centro de cuidados diários da Laval University (Canadá), com o objetivo de identificar a proporção de dentifrício ingerido quando comparado com a quantidade utilizada por crianças pequenas. A quantidade utilizada, bem como a ingerida, variaram de acordo com as idades; sendo que a quantidade ingerida diminuiu com a idade, passando de $59,4 \%$ entre crianças de 2 a 3 anos de idade, para $48,1 \%$ e 43,0\% respectivamente para as de 4 anos e 5 anos de idade, com uma diferença estatisticamente significativa entre as idades de 3 e 5 anos $(t=2,87 ; p<0,01)$. A média ingerida por escovação foi $0,33 \mathrm{~g}$, sendo que as crianças de 5 anos ingeriram a menor quantidade.

RIPA (1991), em sua revisão de literatura, destacou que muitos estudos sobre a retenção de dentifrícios indicaram que as crianças não ingeriam habitualmente o dentifrício; que há uma grande variação na quantidade engolida entre crianças e por uma mesma criança em dias diferentes e que quanto mais jovem, mais facilmente havia a chance de 
ingestão. Dessa forma, se a quantidade média de dentifrício retida por préescolares (por escovação) identificada na sua revisão, foi de $0,134 \mathrm{~g}$, a quantidade de flúor ingerida a partir de um dentifrício com 1.000 ppm de $F$ usado duas vezes ao dia, seria de 0,268 $\mathrm{g}$.

A questão da ingestão de dentifrícios também foi destacada por HOROWITZ (1992) em uma revisão de literatura científica nos Estados Unidos.

ROLDI e CURY (1986) realizaram em Piracicaba-SP, um estudo com o objetivo de avaliar o metabolismo do flúor através da análise comparativa das curvas de absorção plasmática e concentração salivar de flúor e sua excreção urinária, com três voluntários de 20-30 anos, que ingeriram $6 \mathrm{~g}$ de dentifrício suspenso em água destilada. Concluíram que a absorção de flúor após a ingestão está diretamente relacionada com a concentração de flúor ativo nos produtos, e que abrasivos como cálcio e fosfato de cálcio promoveram uma redução nessa absorção. Isto também foi referido em relação à excreção urinária. Acrescentaram que, se houver ingestão de dentifrício durante três escovações diárias, a ingestão e absorção do flúor seria semelhante à recomendada para métodos sistêmicos de administração.

NACCACHE et al. (1992) realizaram um estudo com 405 crianças de 2 a 7 anos de idade da região de Quebec (Canadá). O propósito do estudo foi determinar a contribuição da idade, da quantidade de dentifrício usada e do bochecho após a escovação na variação da ingestão de dentifrício fluoretado. Os três fatores juntos, colocados em um modelo de regressão múltipla, representaram $66 \%$ do total de variação de ingestão de flúor. A quantidade de dentifrício, isolada, representou $60 \%$ do total de variação. Concluíram que a quantidade de dentifrício utilizada era o fator mais importante na ingestão de flúor por crianças de menores idades durante a escovação.

LEVY et al. $1995^{\text {b }}$, na revisão de literatura sobre as diversas formas de ingestão de flúor citada anteriormente, concluíram que em relação aos 
dentifrícios, esforços profissionais no sentido educativo em relação ao limite da quantidade usada em cada escovação poderiam auxiliar no controle da ingestão. Associado a isso, destacaram que os produtores deveriam ser estimulados a cooperar com esses esforços especialmente nas propagandas impressas e por televisão. Esse aspecto também foi apontado por CHEDID et al. (2003)

Além disso, os autores acrescentaram que deveria ser dada ênfase para o uso de uma quantidade mínima ou no máximo um quarto da escova de dentes e que pais e responsáveis deveriam assumir a responsabilidade pela colocação do dentifrício e escovação dos dentes até a criança atingir a idade escolar. Segundo os autores, muita atenção deveria ser dada em relação ao uso de dentifrícios infantis com flavorizantes, aspecto também destacado por RIPA (1991) em sua revisão de literatura, e por LEVY et al. (1992) em seu estudo com 59 crianças de 1 a 4 anos de idade realizado em lowa (Estados Unidos).

LEVY et al. (1992) observaram que $69 \%$ das crianças usaram mais dentifrício infantil (binomial exata: $p=0,03$ ) do que os regulares (ambos com flavorizantes). De forma geral, as crianças usaram, em média, 0,153 g a mais de dentifrício com flavorizantes, diferença estatisticamente significativa ( $p=0,03$; teste de significância de Wilcoxon).

Segundo SPEAR e SAVISKY (1991), o uso de corantes e aromatizantes vinha sendo considerado um estímulo à ingestão de dentifrícios devido à preferência pelas crianças, relacionada ao estímulo visual. Isso foi observado em seu estudo com 435 crianças de localidades de Monongalia e Preston (West Virginia, Estados Unidos).

DEN BESTEN e KO (1996) observaram crianças de 48 a 50 meses de idade de uma creche em Rochester, New York (Estados Unidos), com o objetivo de determinar o efeito na saliva do uso de $0,25 \mathrm{~g}$ de dentifrício fluoretado comparado com 1,0 g (e adultos usando $1,5 \mathrm{~g}$ como categoria de referência). O pico dos níveis de flúor aconteceu imediatamente após a escovação, com resultados similares para a situação em que as crianças 
usaram 1,0 g e adultos usaram 1,5 g. No grupo que usou 0,25 g, a concentração de flúor foi aproximadamente um terço daquela do grupo que usou 1,0 g. Depois de 45 minutos, os níveis de flúor foram semelhantes nos dois grupos, quando comparados com a categoria de referência. Concluíram que 0,25 $\mathrm{g}$ era uma quantidade adequada de dentifrício para ser recomendada somente para crianças que tivessem o risco de ter fluorose dentária.

ROJAS-SANCHEZ et al. (1999) realizaram um estudo para monitorar e comparar a quantidade de flúor ingerido a partir da dieta e do uso de dentifrício por três grupos de 16 a 40 meses de idade, sendo dois grupos de locais com baixos teores de flúor na água (San Juan, Puerto Rico e Connersville, Indiana, Estados Unidos), e um terceiro grupo de uma área com teores adequados de flúor na água (Indianápolis, Indiana, Estados Unidos). Observaram que o maior componente da ingestão de flúor nos locais com baixos teores foi o dentifrício, e que no local fluoretado as crianças ingeriam muito mais flúor a partir dos dentifrícios do que das bebidas.

GONINI (1999) no estudo já citado anteriormente, não encontrou diferenças estatisticamente significativas nas freqüências de fluorose dentária entre as 318 crianças que usaram dentifrício, quando comparou as que usavam menos de $0,25 \mathrm{~g}$ com as que usaram mais do que isto.

Neste trabalho, GONINI (1999) adaptou a forma de medição da quantidade proposta por LEVY e ZAREI-M (1991), onde foi feito o uso de esquema visual para ser indicado pelo entrevistado em relação à quantidade utilizada, com sete categorias e suas respectivas quantidades de dentifrício:
A - faixa grossa de dentifrício: mais de 1,0 g;
B - faixa fina de dentifrício: 1,0 g;
C - 3/4 de faixa fina de dentifrício: $0,75 \mathrm{~g}$;
D - 1/2 de faixa fina de dentifrício: $0,5 \mathrm{~g}$;
E - 1/4 de faixa fina de dentifrício: 0,25 g; 
F- menos de $1 / 4$ de faixa fina de dentifrício: menos de $0,25 \mathrm{~g}$;

$\mathrm{G}$ - pequena quantidade de dentifrício: aproximadamente $0,125 \mathrm{~g}$.

A categoria "D" era semelhante à quantidade proposta por VILLENA e ANDO (1995) baseados em pesquisas que relataram um incremento na prevalência de fluorose dentária na população infantil de países desenvolvidos. Tratava-se do que denominaram técnica transversal de colocação de dentifrício sobre a escova dental a ser recomendada para crianças pré-escolares (variação de 0,32 a 0,48 g de dentifrício). Os autores relataram que a proposta demonstrou facilidade de padronização e de aceitação por pais e responsáveis e que minimizava a ingestão inadvertida do flúor contido nos dentifrícios, reduzindo o risco de fluorose dentária.

VILLENA e CURY (1998) estabeleceram a relação entre quantidade de dentifrício colocada na escova de dentes, quantidade de flúor ingerido, dose por escovação e dose logo após a refeição para três técnicas de colocação de dentifrício na escova: convencional com escova infantil, transversal com escova infantil e transversal com escova modificada (adaptação de escova infantil com remoção de parte dos tufos de cerdas). Estas quantidades estão apresentadas na Tabela 2.

Tabela 2 - Quantidade de dentifrício colocado sobre a escova dental de acordo com técnica/escova empregadas e sua relação com a dose de flúor ingerida.

\begin{tabular}{lcccc}
\hline \multicolumn{1}{c}{$\begin{array}{c}\text { Técnica de } \\
\text { colocação de } \\
\text { dentifrício/escova }\end{array}$} & Dentifrício (g) & $\begin{array}{c}\text { Quantidade } \\
\text { Flúor ingerido } \\
\text { (mg/escovação) }\end{array}$ & Escovação & $\begin{array}{c}\text { Logo após } \\
\text { a refeição }\end{array}$ \\
\hline $\begin{array}{l}\text { Convencional } \\
\text { escova infantil }\end{array}$ & 0,65 & 0,65 & 0,050 & 0,032 \\
$\begin{array}{l}\text { Transversal } \\
\text { escova infantil }\end{array}$ & 0,36 & 0,36 & 0,036 & 0,018 \\
$\begin{array}{l}\text { Transversal } \\
\text { escova modificada }\end{array}$ & 0,13 & 0,13 & 0,013 & 0,007 \\
\hline
\end{tabular}

Fonte: VILLENA e CURY (1998; p. 312)

CHEDID (1999) ao avaliar o efeito anticariogênico da quantidade de dentifrício de 1000 ppm de flúor estabeleceu como quantidade mínima uma situação semelhante à categoria "G" proposta por GONINI (1999), com 0,11g de dentifrício. 
PAIVA et al. (2003) realizaram um estudo com o objetivo de determinar a quantidade de flúor ingerida por crianças de 19 a 38 meses de idade em dois municípios com teores adequados de flúor (0,6-0,8 ppm) na água de abastecimento: Ibiá-MG e Piracicaba-SP. As crianças de Piracicaba permaneciam em período integral em creches e as de lbiá, por terem melhor nível econômico não permaneciam.

Foi determinada a quantidade de flúor ingerida a partir da escovação e a partir de alimentos e bebidas ingeridas durante um período de dois dias. Foi calculada a quantidade total de flúor ingerido e, a partir do limite de 0,05$0,07 \mathrm{mg} \mathrm{F} / \mathrm{kg} /$ dia proposto por BURT (1992), foram estabelecidas as proporções representadas pelas duas formas de ingestão. Observaram que as crianças de Ibiá consumiam menores quantidades de flúor em sua dieta quando comparadas com as de Piracicaba $(p<0,05)$ e nenhuma diferença entre as quantidades de flúor ingeridas a partir dos dentifrícios foi observada entre as crianças dos dois municípios. Nos dois grupos, a quantidade de flúor ingerida a partir dos dentifrícios foi maior do que a partir da dieta $(p<0,05)$.

A realização ou não de enxágüe após a escovação com dentifrício também tem sido investigada por alguns autores.

No estudo piloto de SIMARD et al. (1989), realizado no Canadá, foi observado que crianças que não enxaguavam a sua boca ingeriam 0,49 ( \pm $0,22) \mathrm{mg}$ de flúor a cada escovação, e as que o faziam ingeriam 0,28 ( \pm $0,19) \mathrm{mg}$, diferença estatisticamente significativa $(p<0,05)$.

No estudo NACCACHE et al. (1992), citado anteriormente, também realizado no Canadá, foi observado que crianças que faziam o enxágüe de sua boca ingeriram $0,178 \mathrm{mg}$ de flúor enquanto as que não faziam o enxágüe ingeriam $0,253 \mathrm{mg}$. Essa diferença foi estatisticamente significativa apenas no grupo de 4 a 5 anos de idade.

SJÖEGREN et al. (1994) realizaram um estudo com o objetivo de investigar quatro diferentes procedimentos de risco para ingestão de dentifrícios (dois minutos de escovação seguidos por três bochechos de dois 
minutos; um minuto de escovação seguido por bochecho com água combinada com dentifrício e saliva; dois minutos de escovação com expectoração, sem bochecho com água; ingestão de dentifrício diluído em $100 \mathrm{ml}$ de água deionizada) e a relação com a ingestão e absorção do flúor. Concluíram que o enxágüe após a escovação foi um fator importante na prevenção da ingestão de flúor a partir de dentifrícios. A absorção foi diminuída, quanto mais intenso foi o enxágüe, mas por outro lado houve perda do efeito do flúor devido à menor concentração do mesmo na cavidade bucal. A partir desses resultados, sugeriram que, para crianças de idades menores, seria fundamental que os pais ou responsáveis aplicassem o dentifrício na escova e que a quantidade fosse mínima, para reduzir riscos de ocorrência de fluorose dentária.

ADAIR et al. (1997) realizaram um estudo com 50 pré-escolares de 31 a 60 meses de idade com o objetivo de comparar aspectos relacionados ao uso de dentifrício infantil e o convencional (adulto), entre eles a realização de enxágüe após a escovação. O uso de dentifrício infantil foi significativamente maior e, das crianças que o usavam, apenas $22 \%$ enxaguavam a boca enquanto que nas que usavam dentifrício convencional essa proporção foi de $30 \%$.

\subsubsection{Medicamentos e suplementos com flúor}

Outro fator associado à fluorose dentária, em regiões com e sem água fluoretada tem sido os medicamentos e suplementos com flúor.

Em um estudo realizado na Nova Zelândia, de LIEDFE e HERBISON (1984) avaliaram a prevalência de cárie dentária e defeitos de desenvolvimento de esmalte em 666 crianças de 9 anos de idade, com diferentes histórias de suplementação de flúor. A pesquisa foi realizada nas seguintes áreas: em Hastings com $1 \mathrm{ppm}$ de $\mathrm{F}$ na água de abastecimento, em Wapter, uma área urbana adjacente com flúor natural (0,2 ppm de F), em várias pequenas cidades e na zona rural. 
As crianças foram divididas em grupos: baixa exposição a flúor (CF); exposição à água fluoretada (WF); exposição a tabletes fluoretados no período de 5 a 6 anos de idade (PT) e exposição contínua a tabletes fluoretados (CT). Das crianças expostas a PT, 28,1\% apresentaram opacidades difusas e das expostas a CT esse percentual foi de 49,4\%. Essa prevalência aumentou a partir do grupo CF e essa diferença foi estatisticamente significativa $\left(\chi^{2}=26,34 ; 9 \mathrm{gl} ; \mathrm{p}=0,018\right)$. $O$ estudo confirmou que opacidades difusas apareceram em crianças que fazem ingestão de água com baixos teores de flúor, mas aumentaram nos grupos de crianças que receberam suplementos fluoretados.

BAGRAMIAN et al. (1989) observaram 206 crianças de 9 a 13 anos de idade, residentes em Michigan (Estados Unidos), selecionadas a partir do exame de 2.038 crianças participantes de um projeto de saúde bucal. A prevalência de fluorose dentária foi de aproximadamente $20 \%$, sendo que das 4.868 superfícies dentárias examinadas, 9,2\% estavam afetadas pela fluorose dentária. Não encontraram associação estatisticamente significativa entre a presença de fluorose dentária e o uso de suplementos fluoretados.

PENDRYS e MORSE (1990) buscaram identificar o uso inapropriado de suplementos fluoretados (por exemplo: uso durante o período de residência em área com teores de flúor adequados na água de abastecimento), em uma coorte de 78 crianças de Massachusets e Connecticut (Estados Unidos), que apresentavam fluorose dentária leve ou moderada e com crianças livres de fluorose dentária. Foram coletadas informações para cada ano dos seis primeiros anos de vida sobre: prescrição de pastilhas fluoretadas, tabletes fluoretados, vitaminas fluoretadas em pó e vitaminas fluoretadas em tabletes.

Dos que residiram em área fluoretada nos seis primeiros anos de vida, 40,4\% dos que receberam prescrição de suplementos fluoretados eram casos e $22,7 \%$ eram controles. A maior porcentagem de casos era de crianças de classes média e alta. Concluíram destacando a importância de 
melhorar a educação profissional em relação às recomendações de uso e monitoramento para a apropriada prescrição.

NEWBRUN (1992) discutiu a segurança de produtos fluoretados em relação ao risco de fluorose dentária provocada pela ingestão por préescolares. Concluiu que nenhuma mudança deveria ser feita nos teores de flúor da água de abastecimento, mas sugeriu uma redução na dosagem dos suplementos fluoretados recomendados para crianças de 3 a 6 anos de idade residentes em áreas com teores de flúor abaixo de 0,7 ppm. Apontou ainda, a necessidade de atualização de médicos, farmacêuticos e cirurgiõesdentistas em relação à prescrição correta dos suplementos fluoretados. Segundo o autor, esta deveria ser baseada na concentração de flúor na água de abastecimento, no peso, na altura e na idade da criança.

ISMAIL (1994) em uma revisão crítica da literatura, buscou determinar o efeito dos suplementos fluoretados na prevenção da cárie dentária e o seu papel como fator de risco para fluorose dentária. Segundo o autor, o uso de suplementos fluoretados era inapropriado em locais onde se fazia uso da fluoretação de águas. De forma isolada, os suplementos fluoretados representavam menor risco para a fluorose dentária do que a água fluoretada e os dentifrícios porque sua utilização era mais limitada e o seu uso era menor. Para 0 autor seria importante uma reavaliação da necessidade e da dosagem dos suplementos fluoretados.

RIORDAN (1999) revisou da literatura sobre os riscos e benefícios do uso de suplementos fluoretados por crianças de idades menores. Destacou que o uso de suplementos teve seu efeito comprovado na prevenção da cárie dentária por mais de cem anos, porém o uso desta estratégia deveria ocorrer somente em locais sem fluoretação de água. Relatou que estudos mais recentes tinham sugerido que crianças expostas a outras formas de uso do flúor, como por exemplo dentifrícios, apresentavam um efeito protetor muito pequeno dos suplementos e, por outro lado, um aumento substancial no risco de ocorrência de fluorose dentária. 
ISMAIL e BANDEKAR (1999) em uma meta-análise de trabalhos publicados na Inglaterra entre janeiro de 1966 e setembro de 1997, utilizaram, para identificação dos trabalhos, os unitermos fluorose dental, flúor, suplementos fluoretados ou suplementos, drops e tabletes. Foram identificados 24 estudos, dos quais foram excluídos dez por não apresentarem dados ou terem problemas metodológicos. A revisão confirmou que em comunidades sem água fluoretada, o uso de suplementos fluoretados durante os seis primeiros anos de vida estava associado com o aumento significativo no risco para o desenvolvimento de fluorose dentária.

Algumas pesquisas mostraram essa associação identificada pelo uso ou não de medicamentos.

OSUJl et al. (1988) no estudo citado (item 2.2.2 - Gestação e fatores relacionados), realizado na região metropolitana de Toronto (Canadá), investigaram, entre outros fatores, além do parto prematuro e o baixo peso ao nascer, a ingestão de fórmulas infantis que apresentou uma associação estatisticamente significativa com a presença de fluorose dentária $(O R=3,53$; IC $=1,44-8,65)$.

No de BARDSEN et al. (1999), o uso de fórmulas infantis não apresentou associação estatisticamente significativa.

GONINI (1999) no estudo citado (item 2.2.1 - Tipo de água ingerida), identificou que $12,4 \%$ das crianças utilizaram suplementos fluoretados em algum momento dos seis primeiros anos de vida, porém não encontrou associação estatisticamente significativa entre fluorose dentária e uso inapropriado de suplementos com flúor.

BURT (1999), em uma revisão de literatura discutiu o pequeno efeito pré-eruptivo dos suplementos fluoretados e o risco de ocorrência de fluorose dentária em crianças nos Estados Unidos; visto que elas se encontravam expostas a outras fontes de flúor, como água de abastecimento, dentifrícios, géis e soluções de bochechos, reforçando sua contra-indicação.

A idade de início do uso, associada à duração, dose e freqüência também tem sido investigada em alguns estudos. 
No estudo de OSUJl et al. (1988), uso prolongado de fórmula infantil aumentou a chance de ocorrência de fluorose dentária $(O R=7,1 ; I C=1,14$ $44,45)$, controlado pelo nível de escolaridade materna.

No de BARDSEN et al. (1999), o uso de fórmulas infantis mais de uma vez ao dia apresentou associação estatisticamente significativa, quando comparado com uma única dose diária $(p<0,05)$.

RIORDAN (1993) em uma revisão de literatura sobre os suplementos fluorados na prevenção da cárie dentária, buscou propor um novo esquema de dosagem. Concluiu que o benefício do uso de suplementos pode ser esperado em áreas onde os teores de flúor são baixos e para indivíduos com alto risco de cárie dentária.

LEVY e GUHA-CHOWDHURY (1999) avaliando as informações sobre os níveis de flúor ingeridos a partir de diferentes fontes, identificaram que os estudos destacaram uma variação substancial entre as pessoas. Apontaram que essas variações e a complexidade da ingestão a partir de várias formas deveriam ser consideradas para a recomendação de suplementos fluoretados.

PENDRYS e KATZ (1998) em um estudo do tipo caso-controle realizado em cinco distritos de Connecticut (Estados Unidos), com teores adequados de flúor na água de abastecimento, identificaram uma forte associação estatística $(O R=5,95 ; I C=1,06-33,53)$. entre uso de suplementos fluoretados e a ocorrência de fluorose dentária. Em relação aos casos em que os dentes iniciaram a sua formação de 2 a 6 anos de idade houve associação estatística com o uso de fórmulas infantis em pó (OR=10,77; $\mathrm{IC}=1,89-61,25)$ e com o uso de suplementos $(\mathrm{OR}=8,37 ; \mathrm{IC}=1,68-41,72)$.

PENDRYS et al. (1996) estudo citado (item 2.2.10 - Dentifrícios fluoretados), realizado nos Estados Unidos avaliaram em relação aos suplementos fluoretados o uso ou não no primeiro ano e o uso ou não no período de 2 a 8 anos de idade. $\mathrm{Na}$ análise de regressão logística observaram associação com a fluorose dentária $(O R=2,25 ; I C=1,08-4,69)$ e o uso de suplementos fluoretados nos casos em que os dentes se formaram 
do nascimento até o primeiro ano de vida, e uma associação forte com o uso de suplementos fluoretados $(\mathrm{OR}=7,97 ; \mathrm{IC}=2,98-21$.33) nos casos em que os dentes iniciaram a sua formação de 2 a 6 anos de idade.

WANG et al. (1997) estudo citado (item 2.2.2 - Gestação e fatores relacionados) realizado na Noruega em áreas não fluoretadas, coletaram informações além do peso ao nascer, sobre a duração e freqüência de consumo de suplementos fluoretados. $\mathrm{Na}$ análise de regressão logística observaram associação estatística significativa com a prevalência de fluorose dentária e cada ano adicional de uso regular de suplemento fluoretado $(\mathrm{OR}=1,84 ; \mathrm{IC}=1,43-2,35 ; \mathrm{p}<0,001)$.

Em relação ao responsável pela indicação do medicamento, duas pesquisas identificadas na literatura científica abordaram o tema e estão descritas a seguir.

WOOLFOLK et al. (1989) realizaram um estudo com 543 crianças de 9 a 13 anos de idade, residentes em várias comunidades rurais sem água fluoretada, na região de Michigan (Estados Unidos), com o objetivo de indicar que prescrição de suplementos fluoretados não vinha sendo feita de forma apropriada. Além da fluorose dentária, foram coletadas informações por meio de um questionário com perguntas abertas e fechadas sobre a exposição a fontes de flúor e sobre a prescrição de suplementos fluoretados. Dos que tiveram prescrição de suplementos fluoretados, 67\% a receberam de médicos e o restante de cirurgiões-dentistas. Foi observada uma relação estatisticamente significativa entre a presença de fluorose dentária e a fonte de prescrição (Teste exato de Fisher, $p<0,01$ ), sendo que 36,6\% das crianças que receberam prescrição de médicos tinham presença de fluorose, comparado com apenas $10,3 \%$ que tiveram prescrição por cirurgiõesdentistas.

GONINI (1999) identificou que a maioria (64,8\%) das crianças envolvidas em seu estudo havia recebido de médicos a prescrição de suplementos fluoretados, sendo que apenas 7,4\% tiveram a suplementação prescrita por cirurgiões-dentistas. Embora não tenha encontrado associação 
estatisticamente significativa entre uso de suplementos e fluorose dentária, destacou o aspecto relatado por CURY (1995), que os médicos não procuram conhecer os teores de flúor da água de consumo de seus pacientes, acrescentando a necessidade de intervenções que evitem a prescrição inadequada de suplementos fluoretados.

Em sua tese de doutorado RIBEIRO (2004) buscou identificar a conduta clínica de médicos pediatras quanto à prescrição de suplementos fluoretados no município de São Paulo (São Paulo, Brasil), identificando e avaliando as recomendações de entidades profissionais e instituições públicas de saúde em relação aos suplementos. A proporção de respostas foi de $11,5 \%$, sendo que desses, $12,8 \%$ não prescreveu suplementos e $74,8 \%$ não consideraram necessária a presença de flúor nos mesmos.

\subsubsection{Fatores sócio-econômicos}

Outros aspectos como nível sócio-econômico e grau de escolaridade que podem, dependendo da intensidade que atuam, interferir nos níveis de saúde-doença das populações, foram investigados em pesquisas relacionadas à identificação de fatores associados à fluorose dentária.

No Chile foi realizado um estudo com 693 crianças de 7 a 12 anos de idade provenientes de quatro cidades: lquique (2,2 ppmF), Santiago $(0,0$ ppmF), Valparaiso-Viña (1,0 ppmF) e Temuco (0,3 ppmF). Teve o objetivo de estudar a ocorrência e a severidade da fluorose dentária, além de relacionar com o nível sócio-econômico e a quantidade de flúor na água (MELLA et al. 1994). As crianças foram classificadas de acordo com o nível sócio econômico em dois grupos: nível médio-alto e nível baixo, sem apresentar os critérios de inclusão em cada nível. Foi observada maior proporção de crianças do nível médio-alto sem fluorose dentária, mas a diferença em relação ao nível baixo não foi estatisticamente significativa.

Alguns estudos avaliaram a questão sócio-econômica utilizando a renda familiar e grau de escolaridade de pais/responsáveis. 
OSUJI et al. (1988) no estudo citado anteriormente (item 2.2.2 Gestação e fatores relacionados), realizado na região metropolitana de Toronto (Canadá), observou que o nível de escolaridade da mãe não mudou a associação estatisticamente significativa $(O R=3,53 ; \mathrm{IC}=1,44-8,65)$.entre a presença de fluorose dentária e a ingestão de fórmulas infantis.

BAGRAMIAN et al. (1989), em seu estudo citado anteriormente (item 2.2.10. Medicamentos e suplementos com flúor), realizado em Michigan (Estados Unidos), buscou estabelecer relações com a ocorrência de fluorose dentária e o nível de escolaridade de pais/responsáveis, observando associação $(\mathrm{OR}=2,2)$.

LEVY et al. (1997) em seu estudo citado anteriormente (item 2.2.5 Água para preparo de alimentos) em lowa City (lowa, Estados Unidos), entre as características dos respondentes dos questionários, coletou informações sobre o nível de escolaridade de pais e mães e renda mensal familiar. Em torno de dois terços de pais e de mães tinham até o segundo grau completo e a renda familiar era de vinte dólares ou mais, porém não mencionaram se houve algum tipo de associação com a fluorose dentária.

GONINI (1999) no estudo citado anteriormente (item 2.2.1 - Tipo de água ingerida), realizado em Londrina (Paraná, Brasil), coletou informações sobre a renda familiar (até 3 salários mínimos ou mais de 3 salários mínimos) e sobre a escolaridade da mãe ou responsável (até primeiro grau incompleto e de primeiro grau completo ou mais). Em relação à renda familiar, não observou diferenças estatisticamente significativas na freqüência de fluorose dentária entre indivíduos pertencentes a famílias com renda mais elevada, em relação àqueles provindos de famílias com renda menos elevada. Também em relação à escolaridade não foram observadas diferenças estatisticamente significativas no quadro de fluorose dentária entre grupos de crianças cujo grau de escolaridade da mãe ou responsável era inferior ao primeiro grau, em relação àquelas cujas mães ou responsável haviam completado o primeiro grau. 
MALTZ e SILVA (2001) realizaram um estudo com mil escolares de 12 anos de idade, residentes, desde o nascimento, em Porto Alegre-RS, cujos teores de flúor na água de abastecimento variava entre 0,7 e 1 ppm. Coletaram, por meio de questionário, entre outras informações, o nível de escolaridade dos pais, a renda familiar e o número de pessoas residentes na casa para o cálculo da renda per capita. A média da renda per capita foi de 2,64 $( \pm 0,14)$ salários mínimos, sendo $52,4 \%$ na faixa até dois salários mínimos, $11,1 \%$ na faixa de mais de cinco salários mínimos e $20,5 \%$ de omissão na resposta.

Cerca da metade da amostra apresentou nível de escolaridade até o segundo grau incompleto. Foi observada uma equivalência entre o nível de escolaridade do pai e da mãe (Mann-Whitney, $p<0,001$ ) e, a partir dessa constatação, foi utilizado o mais alto nível de instrução dos pais. Foi observada uma forte correlação (Pearson=0,66; $p<0,01$ ) entre os níveis de renda per capita e o grau de instrução dos pais. Em relação à prevalência e severidade da fluorose dentária, não foram observadas associações estatisticamente significativas.

Do exposto, pode-se observar que tanto os fatores associados à ocorrência de fluorose dentária são numerosos como as formas de apreendê-los e mensurá-los são variadas.

Por essas, entre outras razões, MASCARENHAS (2000) afirmou que os resultados e conclusões dos diversos estudos não têm sido similares e, em algumas situações têm sido contraditórios e confusos.

Além da dificuldade no diagnóstico clínico da fluorose dentária, cabe acrescentar os possíveis vieses produzidos quando os pais/responsáveis respondem a entrevistas sobre a exposição de seus filhos a fontes de flúor em idades precoces, o que vai exigir maior cuidado no planejamento de estudos analíticos (PENDRYS 1999).

Como se pode observar com base em aspectos abordados na literatura científica, além dos dentifrícios e suplementos fluoretados citados 
por BOWEN (20002), múltiplas fontes de flúor têm sido apontadas e estudadas em relação à sua associação com fluorose dentária.

Sob este referencial teórico e considerando a importância da produção de conhecimento sobre a influência dessas múltiplas fontes de flúor em populações expostas à água fluoretada foi feita a investigação no Município de Ribeirão Pires - SP. 


\section{OBJETIVOS}

\subsection{Objetivo geral}

Identificar os fatores associados à fluorose dentária em local com água fluoretada e sugerir medidas de prevenção e controle a serem consideradas no planejamento e avaliação de ações de saúde.

\subsection{Objetivos específicos}

3.2.1. Medir separadamente o grau de associação à fluorose dentária dos seguintes fatores:

3.2.1.2. Sócio-econômicos:

- grau de escolaridade dos pais;

- profissão dos pais.

3.2.1.3. Formas sistêmicas de uso do flúor:

- tipo de água utilizada para ingestão e para preparo de alimentos;

- uso de filtro para água;

- tipo de leites, chás, sucos e bebidas consumidos;

- tipo de recipiente utilizado para preparo de alimentos,

- tipo de peixe consumido;

- tipo de medicamento consumido.

3.2.1.4. Formas tópicas de uso do flúor:

- tipo, quantidade e freqüência de uso de dentifrício;

- idade de início de uso de dentifrício;

- número de escovações dentárias diárias;

- responsável pela colocação de dentifrício;

- exposição e freqüência de uso de produtos com flúor na pré-escola.

3.2.2. Medir conjuntamente o grau de associação à fluorose dentária dos fatores mais significativos. 


\section{MÉTODO}

\subsection{Contexto da pesquisa}

Essa pesquisa foi realizada no início do século XXI, período no qual têm sido relatadas mudanças no perfil epidemiológico da cárie dentária no Estado de São Paulo (USP-FSP 1999), devido ao uso de flúor em larga escala, combinado com ações educativas e práticas de higiene pessoal.

Nesse contexto, especialistas e instituições vêm reiterando a necessidade de utilização de produtos fluoretados apenas quando o seu emprego está efetivamente indicado e, ainda, associando-se adequadamente diferentes métodos, de modo a prevenir a cárie dentária e limitar a ocorrência de fluorose dentária (SÃO PAULO 2000; CDC 2001).

\subsection{Tipo de estudo}

Realizou-se um estudo epidemiológico observacional, de caráter analítico, do tipo caso-controle (SCHLESSELMAN 1982). A escolha desse tipo de estudo justifica-se pelas limitações dos estudos transversais. Embora os últimos tenham vantagens como simplicidade, baixo custo, rapidez, objetividade e sejam uma boa opção para descrever as características dos eventos na população, não conseguem descrever a exposição ocorrida no passado de forma a estabelecer relação causal e investigar vários fatores simultaneamente (PEREIRA 1995).

\subsection{Local do estudo}

O estudo foi conduzido no município de Ribeirão Pires - SP, situado a sudeste da Região Metropolitana da Grande São Paulo, tendo como limites os municípios de Santo André, Mauá, Rio Grande da Serra e Suzano (RIBEIRÃO PIRES 1999). Foi criado em 1.953, emancipado de Santo André e em 1.998 foi transformado em Estância Turística de Ribeirão Pires (RIBEIRÃO PIRES 2001). 
Tem uma área territorial de $107 \mathrm{~km}^{2}$, com $20 \mathrm{~km}^{2}$ de área urbanizada, sendo $100 \%$ em área de manancial das bacias hidrográficas do reservatório Billings, Taiaçupeba e Guaió. Localiza-se na Serra de Paranapiacaba, segmento da Serra do Mar, onde predomina o clima tropical de altitude, com temperatura máxima de $32^{\circ}$, mínima de $5^{\circ}$ e média de $16^{\circ}$. Segundo dados da Fundação Instituto Brasileiro de Geografia e Estatística (IBGE) no ano 2000 a população era de 104.508 habitantes (4,5\% da população da Região do Grande $A B C$ ), com um crescimento de $3,8 \%$ ao ano.

Em 2.002, o valor do Índice de Desenvolvimento Humano (IDH) estimado pela Fundação Seade era 0,805 e o Coeficiente de Mortalidade Infantil 13,8 (RIBEIRÃO PIRES 2003). O tipo de residência predominante no município $(93,4 \%)$ eram casas sendo $70 \%$ próprias e pagas.

Em relação ao grau de instrução do chefe da família, 53\% tinham entre $1^{\circ}$ grau incompleto a $2^{-}$grau incompleto, com uma proporção de analfabetos de 4,7\%. O setor econômico predominante entre os empregados era a prestação de serviços $(42,2 \%)$, seguida da indústria (38,9\%) com uma pequena parcela no comércio $(10,2 \%)$.

O município está dividido em oito regiões (Figura 1):

- Região 1 - Represa: envolve 12 bairros (Sítio do Francês, Jardim da Paz, Jardim Vista Linda, Chácara Icatuaçu, Jardim Planteucal, Balneário Palmira, Chácara Engenho da Serra, Sítio Taquaral, Califórnia Paulista, Jardim Caçula, Jardim Alteza e Fazenda Bromberg), com 6.079 habitantes;

- Região 2 - Centro Alto: envolve 27 bairros (Vila São Manoel, Jardim Celso, Vila Sueli, Jardim Santa Eliza, Jardim do Mirante, Vila Ema, Vila Mortari, Jardim São Domingos, Vila Zampol, Vila Eugênio Luppi, Jardim Santa Inês, Núcleo Colonial, Vila Nova Suíça Santista, Vila Maristela, Vila São José, Jardim Garibaldi, Estância Noblesse, Estância Santo Antônio, Vila Rosal, Vila Aurora, Subdivisão Octavio Zampol, Recanto Suíço, Parque do Governador, Jardim Valentina, Vila Tavolaro, Vila das Palmeiras e Sítio dos Vianas), com 23.022 habitantes; 


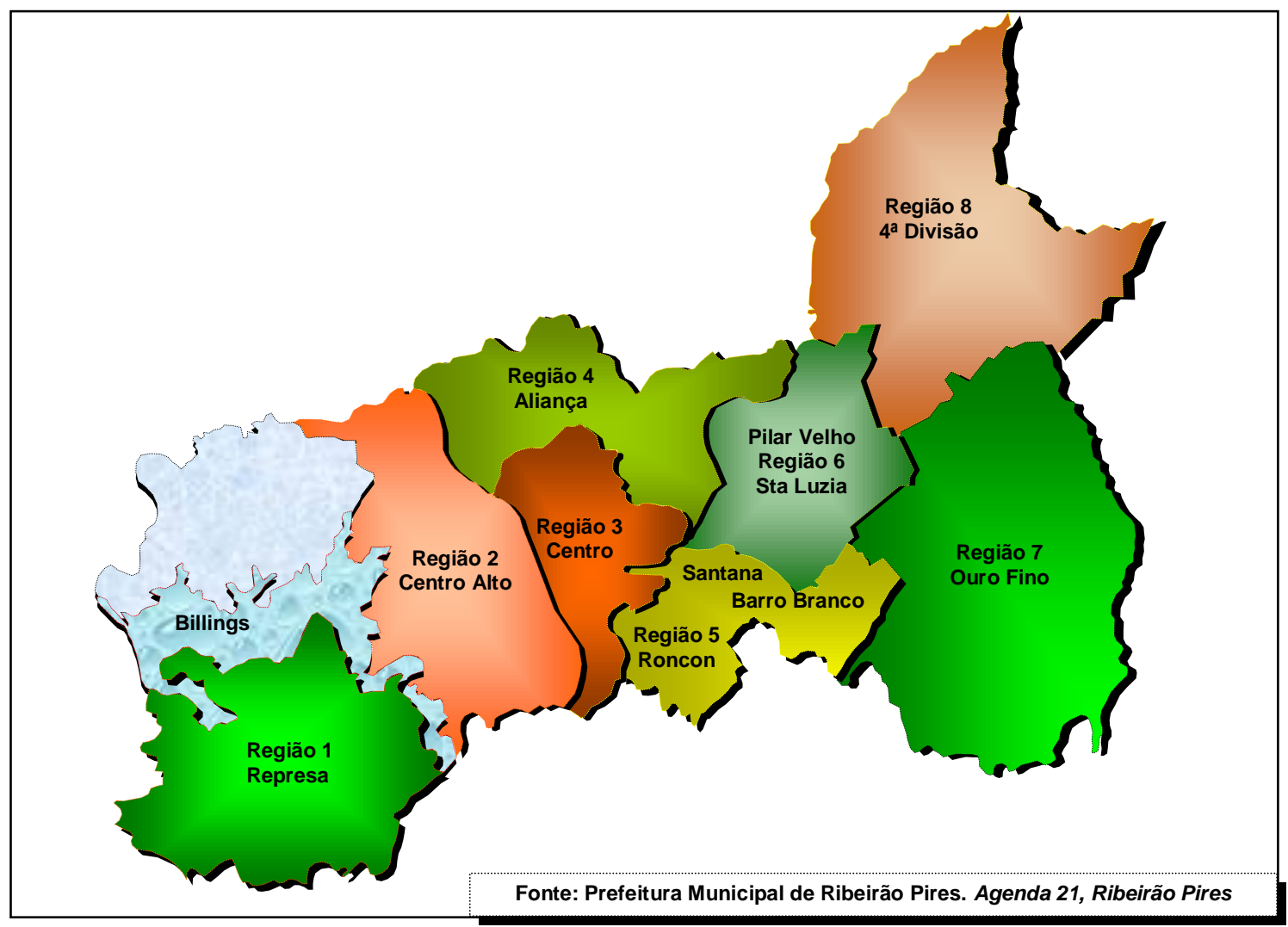

Figura 1 - Divisão Regional do Município de Ribeirão Pires

- Região 3 - Centro: envolve 36 bairros (Recanto Vista Alegre, Jardim Boa Sorte, Jardim Dois Melros, Vila Colônia, Jardim Alvorada, Jardim Colonial, Vila Sonia, Vila Maracá, Vila Fonseca, Jardim Santa Cruz, Vila Manoel Dourado, Vila Ribeirão, Subdivisão Helena Del Corto, Vila Albertina, Vila Marquesa de Santos, Vila Aparecida, Vila Fiorentina, Vila Oneidda, Vila Icleia, Planalto Bela Vista, Jardim Itacolomy, Vila Conceição, Vila Bertoldo, Estância Paulista, Jardim Panorama, Vila Cleide, Vila Prisco, Vila Anísio, Vila Nova Fortuna, Jardim Santa Cruz, Vila Maria, Vila Guerda, Cia Pastoril, Vila Carolina e Vila Sobrinho), com 17.093 habitantes;

- Região 4 - Parque Aliança: envolve 15 bairros (Jardim Esperança, Fazenda Bandeirante, Estância das Rosas, Jardim Santo Antônio, Jardim Serrano, Jardim Lisboa, Chácara Aliança, Vila Belmiro, Parque Aliança, Vila Gomes, Vila Nina Rosa, Vila Monteiro, Sítio Santa Helena, Jardim Guanabara e São Caetaninho), com 17.682 habitantes;

- Região 5 - Santana: envolve 20 bairros (Vila Pereira Barreto, Vila Oásis, Vila Santo Antônio, Jardim Itapeva, Vila Érica Yara, Jardim Sant'Ana, Jardim 
Centenário, Vila Amélia, Vila Caiçara, Jardim Capistrano, Herdeiros de Luiz Roncon, Vila Nova, Jardim Luso, Morro do Embaixador, Vila Mara, Jardim São Francisco, Jardim Ribeirão Pires, Roncon, Barro Branco e Bosque Santana), com 10.662 habitantes;

- Região 6 - Santa Luzia: envolve 15 bairros (Estância Hidromineral Iramaia, Chácara Nossa Senhora do Pilar, Jardim do Pilar Velho, Jardim Santa Rosa, Jardim Petrópolis, Jardim Ideal, Jardim Boa Vista, Jardim Santa Luzia, Vale do Sol, Estância Hollywood, Parque das Fontes, Jardim Jaqueline, Vila Moderna, Parque Santa Luzia e Jardim Nossa Senhora de Fátima), com 12.908 habitantes;

- Região 7 - Ouro Fino: envolve 26 bairros (Sítio Itrapoá, Subdivisão Nobuo Yamamoto, Sítio Santa Helena, Sítio Santana, Jardim Rancho Alegre, Vila Ouro Fino, Vila Yara, Jardim Sol Nascente, Vila Siqueira, Estância Santista, Jardim Califórnia, Jardim Aymoré, Sítio Pouso Alegre, Subdivisão Eduardo V. Nardelli, Vila Casa Branca, Vila Mery, Estância São Jorge, Jardim dos Eucaliptos, Jardim Bandeirantes, Jardim Unnião, Vila Lusitânia, Jardim Novo Ouro Fino, Jardim Aprazível, Chácara das Flores, Casa Vermelha e Soma), com 9.970 habitantes;

- Região 8 - Quarta Divisão: envolve 13 bairros (Jardim Itaquera, Chácara Paraíso, Vila Santa Isabel, Vila Rica, Chácara Rosalina, Jardim de Verão, Jardim Zilda, Recanto leda, Recanto Irani, Recanto Week End, Subdivisão Irmãos Del Corto, Tanque Caio e Vila Bonita), com 7.092 habitantes (RIBEIRÃO PIRES 2001).

O município enquadra-se no sistema de gestão plena dos serviços básicos de saúde desde 1.999 e os atendimentos na área de saúde bucal são representavam 9,2\% dos procedimentos individuais da atenção primária prestada pelo município nos anos de 2.002 e 2.003.

Com relação à saúde bucal, a maior parte da população tem acesso a água fluoretada, sendo que apenas os bairros de Chácara Viana (Região 2 Centro Alto); Jardim Pereira Barreto (Região 5 - Santana), Jardim Iramaia (Região 6 - Santa Luzia) e Jardim Santista e Jardim Lusitano (Região 7 Ouro Fino), não possuem rede distribuidora de água. $\mathrm{O}$ abastecimento do 
município é procedente da Estação de Tratamento de Água do Sistema Rio Claro (UMESP 2001).

Conforme documento expedido pela Companhia de Saneamento Básico do Estado de São Paulo em 15 de março de 2.000, à Secretaria Municipal da Saúde, a água começou a ser fluoretada no ano de 1.984.

Desde 1.996, existe um controle sistemático mensal dos teores de flúor na água de abastecimento público do município, através de um programa de vigilância sanitária coordenado pela Direção Regional de Saúde II - Santo André, da Secretaria de Estado da Saúde de São Paulo (UMESP 2001).

Esse controle tem sido efetuado por meio da coleta de água em oito pontos do município: UBS Jardim Caçula, localizada na Região 1 (Represa); UBS Vila Sueli, localizada na Região 2 (Centro Alto), Centro de Atendimento Odontológico à População (CAOP), localizado na Região 3 (Centro); UBS Jardim Guanabara, localizada na Região 4 (Parque Aliança); UBS Jardim Luso, localizada na Região 5 (Santana); UBS Santa Luzia, localizada na Região 6 (Santa Luzia); UBS Ouro Fino, localizada na Região 7 (Ouro Fino) e UBS IV Divisão, localizado na Região 8 (Quarta Divisão).

Dados fornecidos pela DIR II referentes aos anos de 1.997, $1.998 \mathrm{e}$ 1.999, têm apontado as seguintes variações nos teores de flúor:

- 1.997: 0,47 a 0,85 ppm de flúor;

- 1.998: 0,56 a 0,70 ppm de flúor;

- 1.999: 0,67 a 0,74 ppm de flúor.

No município tem sido desenvolvidas ações coletivas recomendadas em normas do SUS-SP (SÃO PAULO 1992; SÃO PAULO 1999) a 132.340 escolares de 0 a 14 anos de idade e de assistência odontológica individual, onde $o$ atendimento de urgência odontológica tem sido assegurado a todos os cidadãos. As ações programáticas têm sido dirigidas a grupos, social e epidemiologicamente mais vulneráveis com ênfase à população de préescolares e escolares e grupos sociais específicos que freqüentam as 
unidades básicas de saúde. Em 1.997, o município dispunha de 42 cirurgiões-dentistas exercendo atividades na rede pública (UMESP 2001).

\subsection{Planejamento da pesquisa}

Com base em informações epidemiológicas (Tabela 1, apresentada no item 1 - Introdução) e recomendações documentadas em relatório de pesquisa (UMESP 2001); a Coordenação de Saúde Bucal sob responsabilidade do cirurgião-dentista sanitarista $A G M$ e a Secretaria Municipal de Saúde, por meio da autoridade sanitária local (RQ), mostraram interesse em apoiar iniciativas para tentar identificar os possíveis fatores associados à fluorose dentária no município.

Esta preocupação tinha por objetivo redirecionar as ações de saúde bucal no município, bem como as ações intersetoriais com efeitos, direto e indireto, sobre a exposição da população a esses fatores. A combinação dessas circunstâncias com o interesse da autora culminou na condução da presente pesquisa.

Algumas atividades e atribuições foram projetadas após a discussão com a Secretaria Municipal de Saúde de Ribeirão Pires. Inicialmente, associado ao processo de triagem realizado pelo município para classificação dos escolares em função do risco de cárie dentária, foi feita a identificação dos casos de fluorose dentária seguindo os procedimentos descritos no item 4.5.1. A Coordenação de Saúde Bucal solicitou autorização das escolas da rede pública, privada e de pais/responsáveis. Após essa identificação, foram selecionados os controles, adotando-se os procedimentos descritos no item 4.5.2.

Em relação à viabilização das atividades com os entrevistadores a Secretaria Municipal de Saúde fez a indicação da Gerente de Saúde (NPT), que, junto com a enfermeira (AMCS) do Programa de Agentes Comunitários de Saúde - PACS, iniciaram as atividades de organização da agenda de trabalho. 
Identificados casos e controles, os procedimentos técnicos posteriores relativos à entrevista (construção do formulário de entrevista e treinamento dos entrevistadores), coleta, transcrição, digitação e tabulação dos dados; análise estatística e elaboração de relatório final para o município foram conduzidos.

Durante o desenvolvimento das entrevistas, houve mudança de titular na Secretaria Municipal de Saúde, a qual foi assumida por nova autoridade (RC) em 31/07/03. A pesquisa foi apresentada pela Coordenação de Saúde Bucal, mantendo-se o mesmo interesse. Mais recentemente (02/07/04), houve nova mudança e o novo Secretário Municipal de Saúde (CMS) tomou conhecimento da pesquisa.

\subsection{População de estudo}

A população de estudo foi constituída por adolescentes do município de Ribeirão Pires. Para tal, consideraram-se os indivíduos que tinham 12 a 15 anos de idade no momento da triagem (nasceram no período de 01/01/1986 a 31/12/1989). Dados do Sistema de Informação Ambulatorial do Sistema Único de Saúde (SIA-SUS), relativos ao ano 2.001, indicavam para o município uma população de 8.222 adolescentes de 12 a 15 anos $(24,8 \%$ de 12 anos; $24,2 \%$ de 13 anos; $25,4 \%$ de 14 anos e $25,6 \%$ de 15 anos).

Para o Instituto Nacional de Estudos e Pesquisas Educacionais Anísio Teixeira - INEP estavam matriculados em 2.001 nas escolas de ensino fundamental das redes estadual, municipal e privada 9.108 alunos.

O local de identificação dos adolescentes foi a rede de ensino pública e privada, constituída de 26 escolas, sendo 23 da rede pública e 3 da rede privada (Anexo 1). Esses adolescentes foram identificados em atividades de triagem ou screening realizadas pela Coordenação de Saúde Bucal do Município de Ribeirão Pires nesses e nos estabelecimentos da rede privada de ensino.

Essa triagem constituiu-se em exame epidemiológico, realizado com espátula de madeira, com os adolescentes nas salas de aula. Um caderno 
foi montado pela cirurgiã-dentista examinadora (LRSC), onde eram anotadas as informações coletadas: dente parâmetro e grau de fluorose, bem como os dados relativos à identificação (nome do adolescente), localização (endereços residencial e escolar completos e telefones para contato) e filiação. Os cadernos foram encaminhados à pesquisadora para a montagem da base de dados descrita no item 4.6.1.

\subsubsection{Amostra}

Adotando-se como parâmetro uma freqüência relativa de exposição aos fatores de risco para fluorose dentária igual a 35\% (33,2\% observada estudo de FRAZÃO et al. 2004), e admitindo-se um nível de $5 \%$ de significância estatística, poder do estudo de $80 \%$ e Odds Ratio de 1,5 , foi proposta uma amostra de 400 casos e 400 controles (SCHLESSELMAN 1982).

\subsubsection{Seleção dos casos}

Para este estudo foram considerados casos, os adolescentes que se enquadraram na condição presença de fluorose dentária, isto é, os que apresentaram as formas, muito leve, leve, moderada e severa, identificadas a partir dos critérios do Índice de Dean, recomendado pela Organização Mundial da Saúde (WHO 1997) para estudos populacionais.

Buscou-se assegurar que a amostra de estudo correspondesse aos casos típicos de adolescentes de 12 a 15 anos de idade matriculados nas escolas de ensino fundamental do município de Ribeirão Pires.

Esses casos foram identificados pela cirurgiã-dentista, durante o período de 27/06/2001 a 12/02/2002. Esta profissional participou como examinadora da pesquisa realizada no ano 2.000 , quando a coleta dos dados foi iniciada somente após a obtenção de valores consistentes de concordância intra e interexaminadores, após processo de calibração intensivo, com duração de 36 horas e 403 exames. A profissional atingiu um 
coeficiente Kappa equivalente a 0,78 para a concordância intra-examinador (UMESP 2001).

Os indivíduos portadores de fluorose dentária foram cadastrados em um "banco de casos", obtendo-se um total de 667 adolescentes (Anexo 1). Em relação à idade, esses adolescentes tiveram a seguinte distribuição: 41,4\% com 12 anos; 38,4\% com 13 anos; 15,9\% com 14 anos e 4,3\% com 15 anos. Como o local de identificação foram as escolas de ensino fundamental, não foi possível assegurar as proporções demográficas $(24,8 \%$ de 12 anos; $24,2 \%$ de 13 anos; 25,4\% de 14 anos e 25,6\% de 15 anos), pois neste tipo de escola a concentração de escolares de 12 e 13 anos de idade é maior. Para controlar a qualidade deste cadastro, 35 indivíduos (em torno de $5 \%$ ) foram reexaminados pela autora da presente pesquisa. Esse procedimento teve o objetivo de controlar a fidedignidade na identificação dos casos.

\subsubsection{Seleção dos controles}

Escolares com esmalte dentário normal foram identificados levandose em consideração a lista de casos buscando-se, em um primeiro nível manter as proporções por idade, sexo e etnia em cada escola. Em um segundo nível, as proporções de controles foram incluídas observando-se a região de residência. No total, foram identificados 416 adolescentes, durante o mesmo período, pela mesma cirurgiã-dentista. Em relação à idade, esses adolescentes tiveram a seguinte distribuição: 42,3\% com 12 anos; 39,7\% com 13 anos; 13,7\% com 14 anos e 4,3\% com 15 anos. De modo análogo aos casos não foi possível assegurar as proporções demográficas. Da mesma que os casos, em torno de $5 \%$ dos foram reexaminados pela pesquisadora $(\mathrm{n}=20)$.

Esses procedimentos foram adotados para minimizar possíveis fontes de viés na seleção de controles relativas à construção da base de estudo, ao efeito de possíveis variáveis de confusão e à acurácia na comparabilidade (WACHOLDER et al. ${ }^{\text {a, b, c } 1992) .}$ 
O princípio da base de estudo refere-se ao fato de que casos e controles são representantes da mesma experiência e, dependendo do contexto os sujeitos que tivessem desenvolvido o agravo teriam se tornado casos. Assim, para satisfazer esse princípio, garantiu-se uma amostra aleatória de indivíduos da mesma base dos casos, definida geográfica e temporalmente, assegurando-se a proporcionalidade de indivíduos expostos aos mesmos riscos que os casos em relação à idade, sexo e etnia, considerando-se a área de residência.

Essa estratificação também permitiu controlar possíveis variáveis de confusão. Em relação à acurácia da comparabilidade, buscou-se medir a exposição de interesse para os casos da mesma forma que para os controles.

\subsubsection{Controle da qualidade da base de estudo}

Os exames para o controle da qualidade do cadastro foram realizados pela pesquisadora ("padrão ouro") no dia 20/09/2002 na EE Dr. Felício Laurito (Região 3 - Centro). Foi calculado o coeficiente Kappa para os 55 pares de exames (35 casos e 20 controles) e foram consideradas cinco categorias do Índice de Dean (WHO 1997), sendo excluída a categoria questionável. $O$ valor obtido foi 0,90 (Anexo 2), sendo que as três discordâncias se deram entre as categorias 3 e 4 do índice de Dean. Estas não foram alteradas na base de estudo.

\subsection{Instrumento de coleta dos dados}

\subsubsection{Base de estudo}

As informações obtidas durante as atividades de triagem foram digitadas pela pesquisadora em uma base de estudo buscando cadastrar os casos e controles em 9 (nove) listas, nomeadas de acordo com as 8 (oito) regiões em que está dividido o município; e mais uma com os indivíduos cujos endereços residenciais não permitiram à pesquisadora a identificação da região. 
Esta base foi composta pelos seguintes informações: dente parâmetro e grau de fluorose, bem como os dados relativos à identificação (nome do adolescente), localização (endereços residencial e escolar completos e telefones para contato) e filiação; e serviu para a construção de pequenas folhas volantes, que foram utilizadas na distribuição, entre os entrevistadores das famílias a serem visitadas.

\subsubsection{Formulário de entrevista}

O formulário é a técnica de coleta em que o pesquisador formula questões previamente elaboradas e anota as respostas (GIL 1996). Alguns cuidados foram tomados na elaboração das perguntas como: serem diretas, não sugerirem respostas e estarem ordenadas de forma a facilitar ao entrevistado o menor esforço mental possível (LEFEVRE 1994), tendo em vista o caráter recordatório necessário ao tema da pesquisa.

Para a entrevista estruturada foram elaboradas perguntas abertas e fechadas, que permitissem identificar e registrar os possíveis fatores associados à fluorose dentária utilizando-se como períodos recordatórios "antes" e "depois" de 6 anos de idade; agrupando-se as perguntas de maneira a identificar evidências ou conjunto de evidências, de forma a se chegar tendencialmente ao mais próximo possível do verdadeiro (LEFEVRE 1994).

Foram estabelecidos grupos de acordo com a similaridade das variáveis de exposição. Os grupos de variáveis independentes foram os seguintes: procedência e tempo de residência no município; dados familiares; vida intra-uterina; peso ao nascer; hábitos alimentares e preparo de alimentos na primeira infância; exposição a produtos fluoretados na escola durante a primeira infância; acompanhamento na primeira infância quando não estava na escola; aspectos relacionados ao uso de dentifrícios na primeira e segunda infância; uso de medicamentos na primeira infância e aspectos relacionados à assistência odontológica. 
Um espaço reservado para observações a serem feitas pelo entrevistador durante ou após o processo de entrevista, bem como campos para assinatura do entrevistado e do entrevistador foi assegurado.

A partir dessa proposta, partiu-se para a pesquisa exploratória, cujos passos estão descritos a seguir.

\subsubsection{Primeira etapa da pesquisa exploratória}

A pesquisa exploratória, diferente de um estudo piloto, tem como finalidade elaborar um instrumento baseado nas experiências reais dos sujeitos, no seu vocabulário e ambiente de vida; evitar que predisposições influenciem o pesquisador a perceber a realidade segundo sua ótica (viés do pesquisador) e controlar o máximo possível a subjetividade (PIOVESAN e TEMPORINI 1995).

Foram realizadas 7 (sete) entrevistas pela pesquisadora acompanhada de 2 (dois) agentes comunitários de saúde (MESS e EBS), no bairro denominado Jardim Caçula (Região 1 - Represa), no dia 28/06/2002.

Estas entrevistas foram realizadas com pais/responsáveis de crianças de 10 anos de idade que não tivessem irmãos com idades entre 12 e 15 anos de idade, que poderiam vir a compor a população do estudo.

\subsubsection{Segunda etapa da pesquisa exploratória}

Foram incorporadas no formulário as sugestões efetuadas no exame de defesa do projeto. Os períodos recordatórios foram alterados para gestação, primeiro ano de vida, 1 a 3 anos e 4 a 6 anos de idade.

Foram realizadas 4 (quatro) entrevistas pela pesquisadora, acompanhada de dois agentes comunitários de saúde (PGM e VAS), no bairro denominado Estância Hidromineral Iramaia, localizado na Região 6 Santa Luzia, no dia 19/07/02. 
Neste mesmo dia, o projeto foi apresentado a 46 agentes comunitários de saúde do município, em uma oficina de sensibilização promovida pela enfermeira responsável (AMCS) pelo PACS no município.

A oficina, realizada na Igreja Nossa Senhora de Fátima, situada na Vila Sueli (Região 2 - Centro Alto), teve duração de 4 (quatro) horas. Nela foram identificados os profissionais que estavam dispostos a participar como entrevistadores, havendo a desistência de apenas um deles. Foram montados dois grupos: um com 20 profissionais para participar do treinamento para entrevistas e da terceira etapa da pesquisa exploratória, e outro com 20 para participar somente do treinamento para a realização das entrevistas.

\subsubsection{Terceira etapa da pesquisa exploratória}

No dia 20/09/2002 foi realizado o treinamento com um grupo de 20 agentes comunitários de saúde (MESS, EBC, FGQ, RCSP, MCS, FDP, PGM, MFBC, WALM, WHV, HAF, MASG, LRS, VES, MRA, MV, MAL, LSOM, EFL e ADBAS).

Em uma oficina de 8 (oito) horas de duração, foi feita a leitura e discussão de cada uma das perguntas, buscando subsidiar os profissionais com os conhecimentos que permeavam cada uma, destacando os cuidados a serem tomados no sentido de não influenciar nas respostas. Esta oficina foi realizada na Igreja da Imaculada Conceição, situada na Vila Valentina (Região 2 - Centro Alto).

Aos entrevistadores foi fornecida uma pasta contendo o material necessário para a condução das entrevistas (lápis, caneta, borracha, apontador) e catálogos padronizados das medidas estabelecidas para as questões que merecessem estímulo visual ou recordatório (Anexos 3, 4, 5 e 6)

Os agentes comunitários foram orientados a realizar, como treinamento, 2 (duas) entrevistas cada um, utilizando os mesmos critérios 
que a pesquisadora usou na primeira etapa em relação à identificação dos entrevistados, citados no item 4.6.2.1.

Em uma oficina de 4 (quatro) horas de duração, realizada no dia 15/10/2002, no mesmo local que a anterior, foram esclarecidas as dúvidas e novas sugestões foram incorporadas ao formulário de entrevista, chegandose ao modelo final com o conteúdo distribuído em 154 itens (Anexo 7).

O formulário ficou constituído de perguntas abertas e fechadas, distribuídas em 13 blocos assim definidos: informações básicas; identificação e localização; entrevista; filiação e responsabilidade; dados pessoais; procedência e tempo de residência; dados familiares; vida intrauterina; peso ao nascer; $1^{\circ}$ ano de vida; 1 a 3 anos de vida; 4 a 6 anos de vida; exposição na escola; assistência em saúde bucal, além da identificação de evento sentinela, observações, tempo de duração da entrevista e termo de veracidade assinado pelo entrevistado.

Como evento sentinela foi considerada qualquer situação que pudesse surgir durante as entrevistas, e que suscitasse a intervenção imediata da pesquisadora ou inclusão de novas informações a serem coletadas, o que levaria a reunião extraordinária com os entrevistadores, ou até mesmo repetição das entrevistas.

Os campos referentes às informações básicas (grau de fluorose, dente parâmetro, classificação em "caso" ou "controle") foram preenchidos exclusivamente pela pesquisadora; às relativas a identificação e localização da entrevista, pela pesquisadora com conferência do entrevistador; e os demais pelo entrevistador.

O formulário também continha campos para a transcrição das respostas, visto que muitas perguntas eram abertas e foram codificadas, procedimento realizado pela pesquisadora, previamente à digitação.

Embora o formulário não tenha garantido o anonimato e tenha exigido tratamento pessoal, é uma das técnicas mais eficientes e práticas em atividades de investigação, podendo ser aplicada aos mais diversos segmentos da população (PIOVESAN e TEMPORINI 1995). 


\subsection{Treinamento dos entrevistadores}

O segundo grupo, composto de 25 ACS agentes comunitários de saúde (ALS, SAS, EOA, NR, VAS, EF, CGS, SRS, EBSO, FSM, LAS, GFB, MAP, LPA, MMPO, SRP, AMSO, CJP, EMO, FVS, AMSO, LCB, FCS, OMJAF e WSV), passou pelo mesmo processo de treinamento com leitura e discussão das perguntas e embasamento teórico no dia 15/10/2002; em uma oficina com duração de 4 (quatro) horas.

Recebeu o mesmo conjunto de materiais e realizou entrevistas seguindo os critérios citados no item 4.6.2.1 para identificação dos entrevistados nessa fase de treinamento.

Em outra oficina de 8 (oito) horas de duração, realizada no Centro Comunitária de Vila Valentina, localizado no bairro Vila Valentina (Região 2 Centro Alto), foi apresentada a versão final do formulário e dirimidas as dúvidas identificadas durante o treinamento. Nesta fase, por solicitação do serviço, um terceiro grupo de entrevistadores foi incluído na pesquisa, participando da leitura da versão final do formulário.

Enquanto os 45 já treinados faziam a divisão das folhas volantes com os dados das famílias a serem entrevistadas, cujos endereços pertenciam à área de abrangência de sua unidade de saúde; esse terceiro grupo de entrevistadores (ASC, MAST, AWN, DAZ, RIN, CAS e MAB), recebeu as informações necessárias para a realização das entrevistas do treinamento, seguindo os critérios citados no item 4.6.2.1, para posterior discussão no dia da distribuição dos formulários de entrevista.

Após a reorganização das folhas volantes pela pesquisadora, vários entrevistadores se dispuseram a atuar em áreas não cobertas pela sua unidades de saúde, mas que ficavam próximas e uma nova distribuição foi efetuada, não sendo possível ainda o fechamento do número de entrevistas de cada entrevistador.

No dia 28/11/2002 foi feita a discussão sobre as entrevistas realizadas como treinamento pelo terceiro grupo de entrevistadores e foram reorganizadas as folhas volantes com os dados de cada família a ser 
entrevistada. Uma nova reunião foi marcada para o dia 17/12/2002 para uma confraternização e distribuição dos formulários de entrevistas.

Essa distribuição foi feita na Igreja da Imaculada Conceição, no bairro Vila Valentina (Região 2 - Centro Alto) e ficou estabelecido o período de 15/01 a 29/05/2003 para a realização das entrevistas.

Concluída esta etapa, dos 1.083 adolescentes identificados, 236 não pertenciam a nenhuma das regiões cobertas pelos agentes comunitários de saúde. Optou-se por incluir no processo 2 (dois) auxiliares de consultório dentário e 1 (um) técnico em higiene dental.

Em reunião realizada no dia 09/01/2003, no Centro Educacional Ayrton Senna, localizado no Centro (Região 3 - Centro), foi feita a discussão do formulário de entrevista, a distribuição do material necessário e solicitado aos profissionais que seguissem o mesmo processo de treinamento realizado pelos outros grupos.

Os profissionais da equipe de saúde bucal (ACN, ASG, AMSV e TMG) identificaram dos 236 endereços, 160 que poderiam ser entrevistados.

Em reunião realizada no dia 24/02/2003, no mesmo local, foram dirimidas as dúvidas e distribuídos os formulários de entrevista. Ficou estabelecido o período de 10/03 a 30/09/2003 para a realização das entrevistas.

Do total de 1.083 famílias identificadas, 76 não foram incluídas para o processo de entrevistas pelas dificuldades de deslocamento ou por desconhecimento dos profissionais em relação à localização das residências. A distribuição das 1.007 entrevistas (634 casos e 373 controles) está apresentada no Quadro 1. Tanto os entrevistadores quanto os entrevistados desconheciam se os adolescentes estavam incluídos como casos ou controles (duplo cego). 
Quadro 1 - Número de entrevistas distribuídas, segundo profissional. Ribeirão Pires, São Paulo, Brasil, 2005.

\begin{tabular}{|c|c|c|c|c|c|}
\hline Entrevistador & Código & № & Entrevistador & Código & $\mathrm{N}^{\circ}$ \\
\hline MES & 1 & 28 & FSM & 30 & 5 \\
\hline EBS & 2 & 11 & LAS & 31 & 20 \\
\hline $\mathrm{FGQ}$ & 3 & 10 & GFB & 32 & 8 \\
\hline RCSP & 4 & 8 & MAP & 33 & 15 \\
\hline MCS & 5 & 17 & LPA & 34 & 8 \\
\hline FDP & 6 & 12 & MMPD* & 35 & 15 \\
\hline PGM & 7 & 12 & SRP & 36 & - \\
\hline MFBC & 8 & 18 & AMSO & 37 & 24 \\
\hline WIALM & 9 & 13 & CJP & 38 & 10 \\
\hline WHV & 10 & 30 & EMO & 39 & 15 \\
\hline HAF & 11 & 25 & FVS & 40 & 27 \\
\hline MASG & 12 & 15 & AMSO & 41 & 12 \\
\hline LRS & 13 & 11 & LCB & 42 & 17 \\
\hline VES & 14 & 10 & FCS & 43 & 32 \\
\hline MRA & 15 & 36 & OMJAF & 44 & 27 \\
\hline MV & 16 & 10 & WS & 45 & 18 \\
\hline MAL & 17 & 8 & ASC & 46 & 8 \\
\hline LSOM & 18 & 3 & MAST & 47 & 05 \\
\hline EFL & 19 & 21 & AWN & 48 & 13 \\
\hline ADBAS & 20 & 6 & $\mathrm{DAZ}$ & 49 & 5 \\
\hline ALS & 21 & 11 & RIN & 50 & 13 \\
\hline SAS & 22 & 7 & CAS & 51 & 24 \\
\hline EOA & 23 & 3 & MAB & 52 & 37 \\
\hline NR & 24 & 9 & ARCM & 53 & 1 \\
\hline VAS & 25 & 10 & ACN & 54 & 31 \\
\hline$E F$ & 26 & 15 & $\mathrm{ASG}^{* *}$ & 55 & - \\
\hline CGS & 27 & 17 & AMSV & 56 & 93 \\
\hline SRS & 28 & 16 & TMG & 57 & 112 \\
\hline EBSO & 29 & 20 & \multirow{2}{*}{\multicolumn{2}{|c|}{ Sub-total }} & \multirow{2}{*}{595} \\
\hline Sub-total & & 412 & & & \\
\hline
\end{tabular}

* Afastamento por licença médica.

** Afastamento por problemas pessoais. 


\subsection{Monitoramento do processo de entrevistas}

Os entrevistadores tiveram os telefones da pesquisadora à disposição para esclarecimentos e necessidade de informação de evento sentinela e, durante o período de entrevistas foram feitos, pela pesquisadora, contatos telefônicos quinzenais para identificar dificuldades e funcionar como estímulo ao trabalho.

Em meados do mês de maio de 2003, houve uma reestruturação no PACS, com a demissão da maioria dos agentes, ficando apenas os da Região 8 Ouro Fino. A maior parte deles conseguiu concluir o trabalho e as entrevistas que não foram realizadas foram redistribuídas para a equipe de saúde bucal.

\subsection{Variáveis de estudo}

\subsubsection{Variável dependente}

Foi considerada a presença ou não de fluorose dentária. Como presença, foram incluídas as formas muito leve, leve, moderada e severa identificadas a partir dos critérios do Índice de Dean, recomendado pela Organização Mundial da Saúde (WHO 1997) para estudos populacionais. Para sua aplicação, examina-se o indivíduo e, identificados sem secagem os dois dentes mais afetados pela fluorose dentária, faz-se a classificação com base na condição observada no dente menos afetado dos dois, utilizando-se os seguintes códigos e critérios:

[0] esmalte normal: o esmalte apresenta translucidez usual com estrutura semi-vitriforme; a superfície é lisa, polida, cor creme clara;

[1] fluorose questionável: o esmalte revela pequena diferença em relação à translucidez normal, com ocasionais manchas esbranquiçadas; este código é utilizado quando a classificação "normal" não se justifica;

[2] fluorose muito leve: áreas esbranquiçadas opacas, pequenas manchas espalhadas irregularmente pelo dente mas envolvendo não mais que $25 \%$ da superfície; inclui opacidades claras nas pontas das cúspides de molares; [3] fluorose leve: a opacidade é mais extensa, mas não envolve mais que $50 \%$ da superfície; 
[4] fluorose moderada: todo esmalte dentário está afetado e as faces sujeitas à atrição mostram-se desgastadas; há manchas castanhas ou amareladas freqüentemente desfigurantes;

[5] fluorose severa: a hipoplasia está generalizada e a própria forma do dente pode ser afetada; o sinal mais evidente é a presença de depressões no esmalte, que parece corroído e com manchas castanhas generalizadas.

Durante o processo de triagem coletaram-se as seguintes variáveis relacionada à variável dependente:

- dente parâmetro (DENPAR): dos dois dentes mais afetados para fluorose dentária, o menos afetado foi indicado;

- grau de fluorose dentária (GF): critérios do Índice de Dean recomendados pela Organização Mundial da Saúde (WHO 1997);

\subsubsection{Variáveis independentes}

Ainda durante 0 processo de triagem coletou-se a data de nascimento(DTNASC): dia, mês e ano, para cálculo da idade. As demais variáveis foram coletadas durante o processo de entrevista e estão divididas nos seguintes grupos:

\section{Filiação - responsabilidade}

- nome do pai e profissão (PROFPAI): conferência do nome do pai e pergunta aberta para posterior classificação pela codificação do manual para preenchimento de declaração de imposto de renda (BRASIL 2003);

- grau de escolaridade do pai (GRESCP): escolha pelo entrevistado de uma das categorias apresentada no formulário;

- nome da mãe e profissão (PROFMAE): conferência do nome da mãe e pergunta aberta para posterior classificação pela codificação do manual para preenchimento de declaração de imposto de renda (BRASIL 2003);

- grau de escolaridade da mãe (GRESCM): escolha pelo entrevistado de uma das categorias apresentada no formulário;

- nome do responsável e profissão (PROFRESP): conferência do nome do responsável (se não tiver pai e mãe) e pergunta aberta para posterior 
classificação pela codificação do manual para preenchimento de declaração de imposto de renda (BRASIL 2003);

- grau de escolaridade do responsável (GRESCR): escolha pelo entrevistado de uma das categorias apresentadas no formulário.

\section{Dados pessoais}

- sexo do adolescente (SEXO): feminino e masculino;

- grupo étnico (GETNICO): classificação do adolescente, pelo entrevistado nas categorias, branco, pardo, negro, amarelo e indígena;

- data de nascimento (DTNASC): dia, mês e ano (verificada por meio da visualização de documento de identidade ou certidão de nascimento);

- peso inferido (PESOINF): peso da criança inferido pelo entrevistado;

- altura inferida (ALTINF): altura da criança inferida pelo entrevistado.

\section{Procedência - tempo de residência}

- local de nascimento (LOCNASC): município, estado e país de nascimento do adolescente;

- tempo de residência no município (TRESID): pergunta aberta, acompanhada de uma descrição dos bairros em que residiu e o tempo de residência em cada um, para posterior codificação;

- residência em outro município/estado/país (FRESID): sim e não;

- seqüência de mudanças (TRESFORA): pergunta aberta acompanhada de descrição das mudanças e tempos de residência em cada local, para posterior codificação.

\section{Dados familiares}

- renda per capita (RPCAPITA): obtida a partir da divisão da somatória do rendimento familiar (somatória dos rendimentos de todos os moradores) em reais pelo número de moradores na residência (RESID);

- residentes no domicílio (RESID): número de pessoas que residem permanentemente na residência, de forma a permitir o cálculo da renda per capita e consumo médio de água; 
- consumo mensal de água (CONSAG): coletado a partir de comprovante de pagamento de até 3 (três) meses anteriores.

\section{Vida intra-uterina}

- duração da gestação (GEST): pergunta aberta para posterior codificação, utilizando a classificação proposta por REZENDE (1974);

- tipo de parto (PARTO): escolha pelo entrevistado de uma das categorias apresentada no formulário;

- acometimento da mãe por alguma doença durante a gestação (DOENGEST): pergunta fechada (sim e não) para identificação de acometimento por doença e, se afirmativa, campo aberto para identificação do tipo, para posterior codificação;

- consumo de medicamentos pela mãe durante a gestação (MEDIGEST): pergunta fechada (sim e não) para identificação da ingestão de fórmulas infantis nesse período e, se afirmativa, campo aberto para identificação do nome (se o entrevistado não recordasse o nome da fórmula, foi utilizada uma lista com alguns produtos de interesse (Anexo 3), para posterior codificação.

6. Peso ao nascer

- peso ao nascer do adolescente (PESO): pergunta aberta, para posterior codificação.

7. $1^{\circ}$ ano de vida

7.1. Dados do cuidador principal

- identificação da pessoa que cuidou, na residência, do adolescente (CUIDA1): escolha pelo entrevistado de uma das categorias apresentada no formulário;

- grau de escolaridade da pessoa que cuidou, na residência, do adolescente (GRESC1): escolha pelo entrevistado de uma das categorias apresentada no formulário. 


\subsection{Hábitos alimentares}

- duração do aleitamento materno exclusivo (ALEMT1): pergunta aberta para posterior codificação;

- consumo de chás (CHA1): pergunta fechada (sim e não) para identificação da ingestão de chás e, se afirmativa, campo aberto para identificação do tipo de chá, para posterior codificação;

- idade de início do consumo de chás (IDACHA1): pergunta aberta para posterior codificação;

- quantidade consumida de chá (QTCHA1): pergunta aberta para coleta em número de colheres (chá, café, sobremesa, sopa), de "chuquinhas" (30 ou $60 \mathrm{ml}$ ) ou outras medidas, para posterior codificação;

- tipo de água consumida (AGUA1): pergunta fechada (sim e não) para identificação da ingestão de água e, se afirmativa, campo aberto para identificação do tipo de água, para posterior codificação;

- quantidade consumida de água (QTAG1): pergunta aberta para coleta em número de colheres (chá, café, sobremesa, sopa), de "chuquinhas" (30 ou $60 \mathrm{ml}$ ) ou outras medidas, para posterior codificação;

- tipo de leite consumido (LEITE1): pergunta fechada (sim e não) para identificação da ingestão de leite e, se afirmativa, campo aberto para identificação do tipo de leite e se era diluído em água, para posterior codificação;

- início do consumo de leite (IDLEITE1): pergunta aberta para posterior codificação;

- quantidade consumida de leite (QTLEITE1) pergunta aberta para coleta em número de colheres (chá, café, sobremesa, sopa), de "chuquinhas" (30 ou $60 \mathrm{ml}$ ) ou outras medidas, para posterior codificação;

- consumo de fórmulas infantis associadas ao leite (FORM1): pergunta fechada (sim e não) para identificação da ingestão de fórmulas infantis e, se afirmativa, campo aberto para identificação do nome (se o entrevistado não recordasse o nome da fórmula, foi utilizada uma lista com alguns produtos de interesse (Anexo 4), para posterior codificação; 
- início do consumo de fórmulas infantis (IDAFORM1): pergunta aberta para posterior codificação;

- consumo de sucos artificiais (SUCO1): pergunta fechada (sim e não) para identificação da ingestão de sucos artificiais e, se afirmativa, campo aberto para identificação do tipo, para posterior codificação;

- início do consumo de sucos artificiais (IDASUCO1): pergunta aberta para posterior codificação;

- quantidade consumida de sucos artificiais (QTSUCO1) pergunta aberta para coleta em número de colheres (chá, café, sobremesa, sopa), de "chuquinhas" (30 ou $60 \mathrm{ml}$ ) ou outras medidas, para posterior codificação.

\subsection{Preparo de alimentos}

- tipo de água utilizada no preparo de alimentos (AGPREP1): pergunta aberta para identificação do tipo de água utilizada no preparo de alimentos, para posterior codificação;

- uso de filtro para água (FILTRO1): pergunta fechada (sim e não) para identificação da utilização de filtros nesse período e, se afirmativa, campo aberto para identificação do tipo, para posterior codificação;

- tipo de recipiente utilizado no preparo de alimentos (RECPREP1): pergunta aberta para identificação do tipo de recipiente utilizado no preparo de alimentos nesse período, para posterior codificação.

\subsection{Consumo de medicamentos}

- acometimento do adolescente por alguma doença (DOEN1): pergunta fechada (sim e não) para identificação de acometimento por doença e, se afirmativa, campo aberto para identificação do tipo, para posterior codificação;

- consumo de medicamentos pelo adolescente (MEDIC1): pergunta fechada (sim e não) para identificação da ingestão de fórmulas infantis nesse período e, se afirmativa, campo aberto para identificação do nome (se o entrevistado não recordasse o nome da fórmula, foi utilizada uma lista com alguns produtos de interesse (Anexo 3), para posterior codificação; 
- início do consumo de medicamentos (IDAMED1): pergunta aberta para posterior codificação;

- tempo de uso de medicamentos (TEMPMED1): pergunta aberta para posterior codificação;

- freqüência de uso de medicamentos (FRQMED1): pergunta aberta para posterior codificação;

- responsável pela indicação do medicamento com flúor (INDMED1): opção entre as categorias apresentadas no formulário e, se necessário, a codificação de outros tipos identificados.

7.5. Uso de produtos de higiene bucal

\subsubsection{Uso de produtos com flúor na residência}

- uso de produtos com flúor, exceto dentifrício (PRODFL1): pergunta fechada (sim e não) para identificação do uso de algum produto e, se afirmativa, campo aberto para identificação do nome ou tipo, para posterior codificação.

\subsubsection{Uso de dentifrícios}

- hábito de escovar os dentes (ESCOVAR1): sim e não;

- responsável pela escovação (RPESCOV1): escolha pelo entrevistado de uma das categorias apresentada no formulário;

- uso (DENT1): pergunta fechada (sim e não) para identificação do uso de dentifrício e, se afirmativa, campo aberto para identificação do nome ou tipo, para posterior codificação;

- início de uso do dentifrício (IDADENT1): pergunta aberta para posterior codificação;

- tamanho da cabeça da escova (ESCOVA1): opção entre as categorias apresentadas no mostruário padronizado (Anexo 5);

- freqüência de escovação (FRQESC1): foi coletado o número de escovações diárias para posterior codificação;

- quantidade de dentifrício (QTDENT1): foi coletada a partir de uma adaptação proposta pela autora do esquema visual sugerido por LEVY e ZAREI-M (1991) e modificado por GONINI (1999) (Anexo 6); 
- responsável pela colocação do dentifrício no domicílio (RPDENT1): opção entre as categorias apresentadas no formulário e, se necessário, a codificação de outros tipos identificados;

- bochecho após a escovação (BOCHPOS1): hábito ou não de fazer bochechos com água após a escovação;

- freqüência de bochechos após a escovação (FRQPOS1): foi coletado o número de bochechos para posterior codificação;

- ingestão de dentifrício (INGDENT1): tentativa de identificar o hábito ou o prazer em ingerir dentifrício;

- duração da escovação (TEMPESC1): pergunta aberta para posterior codificação.

\section{De 1 a 3 anos de idade}

As variáveis semelhantes às coletadas para o $1^{\circ}$ ano de vida tiveram, na sua codificação, a substituição do dígito "1" por "2". Em alguns grupos, foram acrescentadas algumas variáveis pertinentes a esse período de vida.

A seguir, serão apresentadas, para cada grupo, as codificações das semelhantes às coletadas para o $1^{\circ}$ ano de vida e as explicações sobre as que foram incluídas.

\subsection{Dados do cuidador principal}

As codificações foram: CUIDA2 e GRESC2.

\subsection{Hábitos alimentares}

As codificações foram: ALEMT2, TPALEMT2, CHA2, IDACHA2, QTCHA2, AGUA2, TIPAG2, QTAG2, LEITE2, IDLEITE2, QTLEITE2, FORM2, IDAFORM2, SUCO2 e IDASUCO2.

Foram acrescentadas:

- consumo de outros tipos de bebida (BEBIDA2): pergunta fechada (sim e não) para identificação da ingestão de outras bebidas, exceto leite e sucos artificiais e, se afirmativa, campo aberto para identificação do 
nome ou tipo, para posterior codificação; essa variável foi compreendida no primeiro ano de vida na variável SUCO1;

- início do consumo de outros tipos de bebida (IDBEBID2): pergunta aberta para posterior codificação;

- quantidade consumida de outros tipos de bebida (QTBEBID2) pergunta aberta para coleta quantidade consumida, para posterior codificação;

- consumo de peixes (PEIXE2): pergunta fechada (sim e não) para identificação da ingestão de peixes e, se afirmativa, campo aberto para identificação do nome ou tipo, para posterior codificação;

- freqüência de consumo de peixes (FQPEIXE2): pergunta aberta, para identificação do consumo semanal de peixes, para posterior codificação.

8.3. Preparo de alimentos

As codificações foram: AGPREP2, FILTRO2 e RECIP2.

8.4. Consumo de medicamentos

As codificações foram: DOEN2, MEDIC2, IDAMED2, FRQMED2, TEMPMED2 e INDMED2.

8.5. Uso de produtos de higiene bucal

8.5.1. Uso de produtos com flúor na residência

A codificação foi PRODFL2.

\subsubsection{Uso de dentifrícios}

As codificações foram: ESCOVAR2, RPESCOV2, DENT2, IDADENT2, ESCOVA2, FRQESC2, QTDENT2, RPDENT2, BOCHPOS2, FRQPOS2, INGDENT2 e TEMPESC2.

\section{De 4 a 6 anos de idade}

As variáveis semelhantes às coletadas para o período de 1 a 3 anos de idade tiveram, na sua codificação, a substituição do dígito "2" por "3". A seguir, serão apresentadas, para cada grupo, as codificações das semelhantes às coletadas para o período de 1 a 3 anos de idade. 
9.1. Dados do cuidador principal

As codificações foram: CUIDA3 e GRESC3.

9.2. Hábitos alimentares

As codificações foram: CHA3, IDACHA3, QTCHA3, AGUA3, TIPAG3, QTAG3, LEITE3, IDLEITE3, QTLEITE3, FORM3, IDAFORM3, BEBIDA3, IDBEBID3, QTBEBID3, PEIXE3 e FQPEIXE3.

Para esse período, não foram coletadas informações sobre aleitamento materno (ex.: ALEMT2 e TPALEMT2) e consumo de sucos artificiais, embutido na BEBIDA3 e IDBEBID3.

9.3. Preparo de alimentos

As codificações foram: AGPREP3, FILTRO3 e RECIP3.

9.4. Consumo de medicamentos

As codificações foram: DOEN3, MEDIC3, IDAMED3, FRQMED3, TEMPMED3 e INDMED3.

9.5. Uso de produtos de higiene bucal

9.5.1. Uso de produtos com flúor na residência

A codificação foi PRODFL3.

9.5.2. Uso de dentifrícios

As codificações foram: ESCOVAR3, IDADENT3, DENT3, ESCOVA3, FRQESC3, QTDENT3, RPDENT3, BOCHPOS3, FRQPOS3, INGDENT3 e TEMPESC3.

\section{Exposição na escola}

- idade de início de freqüência à escola (creche, pré-escola, jardim) antes dos 7 anos de idade (IDAESC): pergunta aberta para posterior codificação;

- período que ficava na escola (PERIESC): pergunta aberta para posterior codificação; 
- uso de produtos fluoretados na escola (FLUORESC): pergunta fechada (sim e não) para identificação do uso de algum produto com flúor e, se afirmativa, campo aberto para identificação do nome ou tipo, para posterior codificação;

- freqüência de uso de produtos fluoretados na escola (FQFLUOR): foi coletada a freqüência semanal de uso, independente do tipo de produto, para posterior codificação.

Foi coletado o nome das escolas freqüentadas pelo adolescente antes dos 7 anos de idade, com o objetivo de identificar as ações de saúde bucal desenvolvidas nessas escolas, caso fosse necessário, após análise estatística.

\section{Assistência em saúde bucal}

- início da assistência odontológica (INASS): pergunta aberta, para posterior codificação;

- tipo de serviço mais utilizado (TIPASS): opção entre as categorias apresentadas no formulário e, se necessário, a codificação de outros tipos identificados;

- freqüência de assistência odontológica (FRQASS): pergunta aberta, para posterior codificação;

- substituição da escova (TROESC): pergunta aberta, para posterior codificação;

- parentesco com profissional da área da saúde (PARENT): pergunta fechada (sim e não) para identificação ou não de grau de parentesco com profissional da saúde e, se afirmativa, campo aberto para identificação do grau, para posterior codificação;

- necessidade de tratamento por problemas estéticos devido a manchas (se houver) nos dentes (NECTRAT): foi coletada a informação sobre a percepção de problemas estéticos causados pela fluorose dentária, com a indicação da cor das manchas percebidas pelo entrevistado, como referencial para indicação de assistência. 
12. Coleta de peso e altura reais

Com o objetivo de avaliar se as informações fornecidas pelos entrevistados em relação ao peso e altura inferidos (PESOINF e ALTINF) no grupo "2. Dados pessoais", poderiam ser utilizadas, foi feito um convite para que os adolescentes se dirigissem à unidade de saúde para serem feitas as tomadas das medidas reais:

- peso real (PESOREAL): tomada do peso pelo agente comunitário de saúde ou pessoa indicada por ele, na unidade de saúde;

- altura real (ALTREAL): tomada da altura pelo agente comunitário de saúde ou pessoa indicada por ele, na unidade de saúde.

\subsection{Conferência e transcrição dos formulários de entrevista}

Foi necessária a prorrogação do prazo para conclusão das entrevistas para 28/11/2003. Recebidos os formulários, foi feita uma conferência preliminar e identificada uma amostra composta por um formulário de cada entrevistador para se estabelecer a codificação das variáveis cuja coleta foi feita por meio de perguntas abertas.

Nesse momento foram excluídas variáveis cuja coleta ficou prejudicada pelo grande número de resposta "sem informação" como: quantidade consumida de chá nos três ciclos (QTCHA1, QTCHA2 e QTCHA3), quantidade consumida de água nos três ciclos (QTAGUA1, QTAGUA2 e QTAGUA 3), quantidade de leite consumida nos três ciclos (QTLEITE1, QTLEITE2 e QTLEITE3); idade de início do consumo de fórmulas infantis nos três ciclos (IDAFORM1, IDAFORM2 e IDAFORM3), quantidade de suco artificial consumido nos dois primeiros ciclos (QTSUCO1 e QTSUCO2), quantidade de outros tipos de bebidas consumidos nos dois últimos ciclos (QTBEBID2 e QTBEBID3).

Algumas dessas variáveis foram agrupadas e um protocolo de transcrição foi elaborado (Anexo 8). 
Como o formulário de entrevistas tinha 24 páginas e muitas variáveis foram agrupadas, para facilitar o processo de digitação, foi criada uma ficha para transcrição manual das respostas (Anexo 9).

A transcrição das respostas foi feita no período de 15/12/2003 a 26/02/2004, com encaminhamento de lotes para a digitação.

\subsection{Digitação dos dados}

Os dados foram digitados em uma ficha eletrônica utilizando-se 0 software EPI-INFO, versão 6.04, de domínio público (CDC-WHO 1990). A digitação foi feita por um único digitador (FMC) e foi realizada de forma dupla, originando dois bancos de dados (RIB.rec e RIB02.rec). Foram feitas a validação do processo de digitação e as correções necessárias.

\subsection{Análise dos dados}

Para essa etapa utilizou-se o software EPI-INFO, versão 6.04 (CDCWHO 1990). Após a validação do processo de digitação e as correções necessárias, procedeu-se à tomada das freqüências absolutas e relativas de todas as variáveis; bem como a construção de tabelas cruzadas entre cada uma das variáveis independentes e a variável dependente, realizando-se o teste de associação pelo $\chi^{2}$ (com correção de Yates).

Algumas variáveis tiveram sua coleta prejudicada e apresentaram pelo menos $20 \%$ das respostas com a codificação que indicava "sem informação", tendo sido excluídas das análises posteriores.

Foram as seguintes: renda familiar (RENDAFAM), consumo mensal de água (CONSAG), idade de início de consumo de medicamentos nos três ciclos (IDMED1, IDMED2 e IDMED3); tempo de consumo de medicamentos nos três ciclos (TEPMED1, TEPMED2 e TEMPMED3), idade de início do consumo de chás nos três ciclos e de sucos artificiais nos dois primeiros ciclos (IDCHA1, IDCHA2, IDCHA3; e IDSUCO1, IDSUCO2, IDSUCO3; e IDBEB2 e IDBEB3); freqüência de consumo de outros tipos de bebidas e de 
peixes nos dois últimos ciclos (FRQBEB2, FREQBEB3; e FRQPEIXE2 e FRQPEIXE3), e tempo de duração da escovação nos três ciclos (TEMPESC1, TEMPESC2 e TEMPESC 3); peso e altura inferidos (PESOINF e ALTINF) e peso real e altura reais (PESOREAL e ALTREAL).

As variáveis que tiveram a função de estimular o processo recordatório também não participaram das análises. Foram as seguintes: duração da gestação (GEST); tipo de parto (PARTO), ocorrência de doença durante a gestação (DOENGEST), cuidador do adolescente nos três ciclos (CUIDA1, CUIDA2 e CUIDA3), peso ao nascer (PESONASC); ocorrência de doença nos três ciclos (DOEN1, DOEN2 e DOEN3), hábito de escovar os dentes nos três ciclos (ESCOVAR1, ESCOVAR2 e ESCOVAR3), idade que começou a freqüentar a pré-escola bem como o período de permanência (IDESC e PERIESC).

Algumas, que tiveram a finalidade de se chegar a necessidade de tratamento (NECTRAT), também não foram incluídas nas análises, como: idade de início de assistência odontológica (INASS); tipo e freqüência da assistência odontológica (TIPASS e FRQASS); número de troca de escovas de dentes (TROESC) e parentesco com profissional de saúde (PARENT).

Em seguida, utilizando-se o Programa SPSS 10.0 for Windows, foi verificada a especificação de cada variável e realizada a mensuração das medidas de efeito da associação. A partir dessa mensuração, verificou-se a necessidade de criação de variáveis que expressassem a exposição exclusiva ao fator em cada ciclo ( $1^{\circ}$ ano, 1 a 3 anos e 4 a 6 anos) ou o uso contínuo ao longo de dois ou dos três ciclos. Para esse processo foram consideradas as seguintes situações: tipo de variável independente, tendências de associações (tanto ao longo dos ciclos ou em um ou dois ciclos) e o valor de $p$.

Variáveis derivadas das iniciais foram criadas seguindo-se 0 procedimento que será descrito a seguir. Para tal, será utilizado como exemplo a variável água para preparo de alimentos: $1^{\circ}$ ano (AGPREP1), 1 a 
3 anos (AGPREP2) e 4 a 6 anos (AGPREP3). As freqüências absolutas dessas variáveis estão apresentadas na Tabela 3.

Tabela 3 - Freqüências absolutas de água para preparo de alimentos segundo categorias da variável e ciclos de vida. Ribeirão Pires, São Paulo, Brasil, 2005.

\begin{tabular}{lccc}
\hline \multicolumn{1}{c}{ Categorias } & $\begin{array}{c}\text { AGPREP1 } \\
\left(1^{\circ} \text { ano }\right)\end{array}$ & $\begin{array}{c}\text { AGPREP2 } \\
(1 \text { a } 3 \text { anos })\end{array}$ & $\begin{array}{c}\text { AGPREP3 } \\
(4 \text { a } 6 \text { anos })\end{array}$ \\
\hline 1- Bica & 3 & 1 & - \\
2 - Mina & 3 & 3 & 2 \\
3 - Fonte & 15 & 11 & 7 \\
4 - Poço & 54 & 43 & 41 \\
5 - Outras & 3 & 3 & 1 \\
6 - Encanada & 428 & 447 & 458 \\
- Sem informação & 3 & 1 & - \\
\hline Total & 509 & 509 & 509 \\
\hline
\end{tabular}

Para esse processo, foram utilizados recursos da função Transform do Programa SPSS 10.0 for Windows apresentados no Quadro 2, na seqüência de sua utilização.

Quadro 2 - Recursos do Programa SPSS 10.0 for Windows utilizados na categorização de variáveis.

\begin{tabular}{|c|c|c|}
\hline & & \\
\hline Recurso & Finalidade & Sintaxe \\
\hline Compute & $\begin{array}{l}\text { Selecionar todas as freqüências de uma } \\
\text { variável para uma nova }\end{array}$ & agprept=agprep $1=3$ \\
\hline $\begin{array}{l}\text { Recode into } \neq \\
\text { variables }\end{array}$ & $\begin{array}{l}\text { Recodificar as freqüências de uma } \\
\text { variável para uma nova }\end{array}$ & agprep1 \\
\hline If & Estabelecer condições de inclusão & agprep2=4\&agprep3=4 \\
\hline $\begin{array}{l}\text { Old and news } \\
\text { values }\end{array}$ & Mudar a codificação da variável & código 4 para código 1 \\
\hline If & Estabelecer condições de inclusão & agprep2=6\&agprep3=6 \\
\hline $\begin{array}{l}\text { Old and news } \\
\text { values }\end{array}$ & Mudar a codificação da variável & código 6 para código 2 \\
\hline $\begin{array}{l}\text { System missing } \\
\text { e missing }\end{array}$ & $\begin{array}{l}\text { Recodificar as freqüências de uma } \\
\text { variável para uma nova sem estabelecer } \\
\text { condição }\left(^{*}\right)\end{array}$ & $\begin{array}{l}\text { agprep1=agprept } \\
\text { agprep2=agprept } \\
\text { agprep3=agprept }\end{array}$ \\
\hline
\end{tabular}

$\left(^{*}\right)$ com remoção do recurso if

Com o auxílio dos recursos citados, foi criada uma nova variável denominada AGPREPT, referente à exposição contínua à água para preparo de alimentos nos três ciclos. Tinha quatro categorias (1 - exposição à água 
de poço nos três ciclos; 2 - exposição à água encanada nos três ciclos; 3 demais combinações de exposição e 9 - sem informação). Inicialmente, todas as categorias da variável AGPREP1 foram codificadas como categoria "3" da nova variável (AGPREPT), exceto a categoria "4" da variável AGPREP1, que, sob a condição de que AGPREP2 e AGPREP3 fossem igual a "4", foi codificada como "1", obtendo-se, nessa etapa, as freqüências apresentadas na Tabela 4.

Tabela 4 - Freqüências absolutas (1) de água total para preparo de alimentos segundo fonte de água ao longo dos ciclos. Ribeirão Pires, São Paulo, Brasil, 2005.

\begin{tabular}{|c|c|}
\hline Tipo de água por ciclo & $\mathrm{n}^{\circ}$ \\
\hline 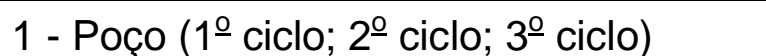 & 36 \\
\hline 3 - Demais & 473 \\
\hline 9 - Sem informação & . \\
\hline Total & 509 \\
\hline
\end{tabular}

Na próxima etapa, a categoria "6" da variável AGPREP1 foi codificada como "2" na nova variável (AGPREPT), sob a condição de que, AGPREP2 e AGPREP3 fossem iguais a "6", obtendo-se as freqüências apresentadas na Tabela 5.

Tabela 5 - Freqüências absolutas (2) de água total para preparo de alimentos segundo fonte de água ao longo dos ciclos. Ribeirão Pires, São Paulo, Brasil, 2005.

\begin{tabular}{lc}
\hline \multicolumn{1}{c}{ Tipo de água por ciclo } & $\mathrm{n}^{\circ}$ \\
\hline 1 - Poço (1ํㅡㄴ ciclo; $2^{\circ}$ ciclo; $3^{\circ}$ ciclo) & 36 \\
2 - Encanada $\left(1^{\circ}\right.$ ciclo; $2^{\circ}$ ciclo; $3^{\circ}$ ciclo $)$ & 422 \\
3 - Demais & 51 \\
9 - Sem informação & - \\
\hline Total & 509 \\
\hline
\end{tabular}

Em seguida, foi criada a categoria "9" da nova variável, referente às respostas "sem informação" comuns às variáveis AGPREP1, AGPREP2 e AGPREP3. As freqüências obtidas nessa etapa estão apresentadas na Tabela 6. 
Tabela 6 - Freqüências absolutas (3) de água total para preparo de alimentos segundo fonte de água ao longo dos ciclos. Ribeirão Pires, São Paulo, Brasil, 2005.

\begin{tabular}{lr}
\hline \multicolumn{1}{c}{ Tipo de água por ciclo } & $\mathrm{n}^{\circ}$ \\
\hline 1 - Poço (1 ${ }^{\circ}$ ciclo; $2^{\circ}$ ciclo; $3^{\circ}$ ciclo $)$ & 36 \\
2 - Encanada $\left(1^{\circ}\right.$ ciclo; $2^{\circ}$ ciclo; $3^{\circ}$ ciclo $)$ & 422 \\
3 - Demais & 48 \\
9 - Sem informação & 3 \\
\hline Total & 509 \\
\hline
\end{tabular}

Procedimentos semelhantes, sempre respeitando o número de categorias de cada variável e os agrupamentos de modalidades que tivessem plausibilidade científica, foram utilizados para as variáveis:

- tipo de água para ingestão (AGUA1, AGUA2 e AGUA3); criando-se a variável AGUAT;

- uso de filtro para água (FILTRO1, FILTRO2 e FILTRO3), criando-se a variável FILTROT;

- uso de dentifrício (DENT1, DENT2, DENT3), criando-se a variável DENTT;

- idade de início dos uso de dentifrício (IDDENT1, IDDENT2 e IDDENT3), criando-se a variável INIDENT;

- quantidade de dentifrício (QTDENT1, QTDENT2 e QTDENT3), criando-se a variável QTDENTT;

- número de escovações (FRQESC1, FRQESC2 e FRQESC3), criando-se a variável FRESCT e,

- responsável pela colocação de dentifrício (RPDENT1, RPDENT2 e RPDENT3), criando-se a variável RPDENTT.

Outras variáveis, como grau de escolaridade do pai (GRESCP); grau de escolaridade da mãe (GRESCM); profissão do pai (PROFP); duração do aleitamento materno no primeiro ciclo (ALEMT1); uso de produtos com flúor na pré-escola (FLUESC) e freqüência de uso de produtos com flúor na préescola (FRQFLU), por não envolverem a exposição por ciclos, tiveram algumas categorias agrupadas, obtendo-se respectivamente as seguintes variáveis: ESCOLP, ESCOLM, PROPAI, ALEMT, PROMAE, FLUESCOL e FRQESCOL. 
Procedeu-se a análise univariada das variáveis independentes que apresentaram associação estatística significativa. O efeito de cada uma sobre o desfecho foi obtido apurando-se a Odds Ratio (OR) e seus intervalos de confiança $\left(\mathrm{IC}_{95 \%}\right)$.

Para determinar o efeito de cada uma das variáveis na presença das demais, foi construídos um modelo de regressão logística múltipla não condicional (KLEINBAUM et al. 1988) que incluiu as seguintes variáveis: responsável pela colocação do dentifrício, água para preparo de alimentos e uso de dentifrício (relacionadas à exposição ao flúor) e interação entre escolaridade do pai e escolaridade da mãe (sócio-econômica).

\subsection{Aspectos éticos}

O projeto foi apresentado ao Comitê de Ética em Pesquisa da Faculdade de Saúde Pública da USP e aprovado (Anexo 10). Foram respeitados os aspectos relacionados às pesquisas com seres humanos (BRASIL 1996).

O princípio da autonomia que implica no consentimento livre e esclarecido dos indivíduos envolvidos ou seus responsáveis, respeitando sua dignidade e sua vulnerabilidade, foi assegurado por meio da elaboração de um termo de autorização da pesquisa onde constaram informações básicas sobre o tipo de agravo investigado, características dos exames e agendamento prévio de entrevista, que foi assinado pelos pais do adolescente selecionado ou seus responsáveis (Anexo 11).

Além disso, os dados individuais relativos aos exames intrabucais e às entrevistas, não foram e não serão divulgados em nenhuma hipótese, e o indivíduo teve a garantia de que não será prejudicado caso não tenha colaborado.

Os princípios da beneficiência e da não maleficiência, que implicam a ponderação dos riscos e exposição dos indivíduos ao mínimo possível de danos, foram respeitados pela observação dos princípios de biossegurança 
durante a execução dos exames; seguindo-se as recomendações da Organização Mundial da Saúde em seus manuais de instruções para levantamentos epidemiológicos (WHO 1987; WHO 1997). Acrescente-se o fato de que nenhuma substância foi aplicada durante os exames intrabucais.

O princípio da justiça-eqüidade foi respeitado. Foi elaborado um protocolo de tratamento ( $\mathrm{CCC}$ ), dentro das técnicas existentes até o momento, para os casos com condição estética desfavorável, e o tratamento ficou sob a responsabilidade da Secretaria Municipal de Saúde de Ribeirão Pires.

Cabe salientar a relevância da pesquisa, cujos resultados poderão indicar medidas de prevenção e controle do agravo a serem adotadas pelo município e para outros serviços de saúde, de forma a trazer benefícios para as crianças que estão com dentes decíduos e permanentes em fase de formação. Além disso, está construído um banco de dados a ser explorado, podendo ser utilizado em futuras pesquisas em saúde bucal coletiva.

Considerando-se a característica observacional do estudo, não ocorreram situações que poderiam ter levado à suspensão ou encerramento da pesquisa. 


\section{RESULTADOS}

O presente estudo, do tipo caso-controle, buscou identificar os fatores associados à rede de causalidade da fluorose dentária no município de Ribeirão Pires - SP.

Casos e controles foram identificados no conjunto de adolescentes de 12 a 15 anos de idade, provenientes de 23 escolas da rede pública e 3 da rede privada de ensino.

Essa identificação, realizada durante um período de aproximadamente sete meses (27/06/2001 a 12/02/2002), foi feita por profissional experiente (Kappa $=0,78$ para concordância intra-examinador), com controle da qualidade do cadastro de casos e controles (reexame de $5 \%$ do total pela pesquisadora com Kappa $=0,90$ ).

Em relação ao tamanho proposto da amostra (400 casos e 400 controles), a partir da relação de 667 adolescentes com fluorose dentária e 416 com esmalte normal, foi possível se entrevistar 509 famílias, que correspondeu a $47 \%$ da população identificada. A taxa de resposta para os 319 casos foi de $48 \%$ e para os 190 controles foi de $46 \%$, semelhantes à taxa do total de respostas. As entrevistas foram realizadas no período de 15/01 a 30/11/2003 e tiveram duração média de 140 minutos.

Nas tabelas 7 a 10 são apresentadas: a descrição geográfica e demográfica da amostra, a distribuição da fluorose dentária entre os casos e os dentes mais afetados, além da percepção dos entrevistados em relação ao comprometimento estético relacionado a manchas.

A descrição das variáveis sócio-econômicas representadas por escolaridade do pai, profissão do pai, escolaridade da mãe e profissão da mãe é feita nas tabelas 11 a 13.

As medidas de tendência central e variabilidade e a diferença de médias entre casos e controles em relação à exposição a aleitamento materno no primeiro ano de vida estão apresentadas na Tabela 14. 
Nas tabelas 15 a 34 são apresentadas descrições das variáveis relacionadas à exposição a flúor sistêmico e tópico: água para ingestão e para preparo de alimentos, consumo de leite com complementos e fórmulas infantis, ingestão de chá, recipiente utilizado no preparo de alimentos, uso de filtro para água, ingestão de sucos, bebidas e peixes, exposição a medicamentos e os responsáveis pela sua prescrição, exposição a bochechos domésticos com soluções, aspectos relacionados à exposição a dentifrícios e exposição a flúor na pré-escola.

A especificação das características sócio-econômicas, das variáveis relacionadas à água, ao uso de dentifrícios e à exposição a flúor na préescola constam das tabelas 35 a 38 .

A análise univariada dos fatores mais importantes e inclusão no modelo de regressão logística múltipla não condicional se encontram nas tabelas 39 e 40.

As seguintes variáveis não foram apresentadas porque tiveram sua coleta prejudicada (pelo menos $20 \%$ das respostas com a codificação "sem informação"): renda familiar; consumo mensal de água; idade de início de consumo de medicamentos nos três ciclos; período de consumo de medicamentos nos três ciclos; idade de início do consumo de chás e de sucos artificiais nos dois primeiros ciclos; frequência de consumo de bebidas e peixes nos dois últimos ciclos; tempo de duração da escovação nos três ciclos; peso inferido e real e altura inferida e real.

Outras variáveis que tiveram a função de estimular o processo recordatório não foram descritas: duração da gestação; tipo de parto e ocorrência de doença durante a gestação; peso ao nascer; cuidador do adolescente nos três ciclos; ocorrência de doença nos três ciclos; hábito de escovar os dentes nos três ciclos; idade de início de freqüência e período que permanência na pré-escola.

Os seguintes itens que tiveram a finalidade de obtenção da avaliação do entrevistado sobre a necessidade de tratamento não foram apresentadas: idade de início de assistência odontológica; tipo e freqüência da assistência 
odontológica; número de troca de escovas de dentes e parentesco com profissional de saúde.

O formulário de entrevista (Anexo 7) continha cinco perguntas $(6,7,8$ 9 e 10) para coletar informações sobre a história de residência do adolescente no sentido de conhecer a exposição à água fluoretada por ciclo para posterior codificação.

A tentativa de codificação por ciclo da exposição à água fluoretada, a partir das variáveis área de residência (AREA1, AREA2 e AREA3) e tempo de residência na área (TAREA1, TAREA2 e TAREA3), resultou em perdas de informação. Estas perdas prejudicaram o detalhamento dessa condição, que foi analisada a partir das variáveis água para ingestão (AGUA1, AGUA2 e AGUA3) e para preparo de alimentos (AGPREP1, AGPREP2 e AGPREP3).

A duração do aleitamento materno no segundo ciclo teve muitas categorias com freqüência nula e suas freqüências não foram incluídas.

As freqüências das respostas sem informação (consideradas "missing") não estão descritas, por esse motivo em várias tabelas a freqüência total não corresponde ao total de entrevistas (509, sendo 319 e 190 controles) .

\subsection{Amostra}

A distribuição geográfica e demográfica da amostra está apresentada na Tabela 7. Foi realizado teste de independência entre cada modalidade de cada variável e o total, para verificar a existência de diferenças estatisticamente significativas entre casos e controles.

Buscou-se respeitar o princípio da base de estudo, isto é, proporcionalidade da amostra em relação à distribuição na população estudada, garantindo-se a comparabilidade. Assim, a amostra aleatória, definida geográfica e temporalmente, assegurou a proporcionalidade de indivíduos expostos aos mesmos riscos que os casos em relação à idade, ao 
sexo e à etnia, considerando-se a área de residência e o tempo de residência no município. Na maioria dos casos as diferenças não foram estatisticamente significativas. Apenas em relação às regiões da residência Centro Alto e Parque Aliança e à idade de 14 anos, essa semelhança não foi assegurada.

Tabela 7 - Número e porcentagem de casos e controles segundo região da residência, residência nos 6 primeiros anos de vida, sexo, idade e etnia. Ribeirão Pires, São Paulo, Brasil, 2005.

\begin{tabular}{|c|c|c|c|c|c|c|}
\hline \multirow{2}{*}{ Variáveis } & & \multicolumn{2}{|c|}{ Casos } & \multicolumn{2}{|c|}{ Controles } & \multirow{2}{*}{$p^{*}$} \\
\hline & & $\mathrm{N}$ & $\%$ & $\mathrm{n}$ & $\%$ & \\
\hline \multirow{8}{*}{$\begin{array}{l}\text { Região } \\
\text { da residência }\end{array}$} & Represa & 41 & 12,9 & 14 & 7,4 & 0,082 \\
\hline & Centro Alto & 69 & 21,6 & 25 & 13,1 & 0,000 \\
\hline & Centro & 31 & 9,7 & 16 & 8,4 & 0,625 \\
\hline & P. Aliança & 35 & 11,0 & 33 & 17,4 & 0,040 \\
\hline & Santana & 36 & 11,3 & 31 & 16,3 & 0,104 \\
\hline & Santa Luzia & 36 & 11,3 & 27 & 14,2 & 0,332 \\
\hline & Ouro Fino & 18 & 5,6 & 15 & 7,9 & 0,318 \\
\hline & $4^{\mathrm{a}}$ Divisão & 53 & 16,6 & 29 & 15,3 & 0,618 \\
\hline \multirow{2}{*}{$\begin{array}{l}\text { Residência } \\
\text { nos } 1^{\text {os }} 6 \\
\text { anos de vida }\end{array}$} & Sim & 234 & 73,4 & 150 & 78,9 & \multirow{2}{*}{0,173} \\
\hline & Não & 85 & 26,6 & 40 & 21,1 & \\
\hline \multirow[t]{2}{*}{ Sexo } & $\mathrm{F}$ & 155 & 48,6 & 95 & 50,0 & \multirow{2}{*}{0,758} \\
\hline & M & 164 & 51,4 & 95 & 50,0 & \\
\hline \multirow[t]{4}{*}{ Idade } & 12 & 120 & 37,6 & 81 & 42,6 & 0,263 \\
\hline & 13 & 139 & 43,6 & 84 & 44,2 & 0,899 \\
\hline & 14 & 51 & 16,0 & 23 & 12,1 & 0,019 \\
\hline & 15 & 9 & 2,8 & 2 & 1,1 & $0,155^{\star *}$ \\
\hline \multirow[t]{6}{*}{ Etnia } & B & 179 & 56,1 & 107 & 56,3 & 0,964 \\
\hline & $P$ & 122 & 38,2 & 75 & 39,5 & 0,816 \\
\hline & $\mathrm{N}$ & 11 & 3,5 & 6 & 3,2 & 0,816 \\
\hline & $A$ & 4 & 1,3 & - & - & $0,153^{* *}$ \\
\hline & 1 & 3 & 0,9 & 2 & 1,0 & $0,616^{* *}$ \\
\hline & Total & 319 & 100,0 & 190 & 100,0 & \\
\hline
\end{tabular}

\footnotetext{
${ }^{*}$ Teste efetuado entre cada modalidade e o total ( $\chi^{2}$ de Pearson)
} 
** Teste exato de Fisher 
A distribuição dos casos de acordo com os graus de fluorose dentária e os dentes mais afetados pela fluorose dentária, considerados como parâmetros para a classificação, estão apresentados respectivamente na Tabela 8 e na Tabela 9.

Tabela 8 - Número e porcentagem de casos segundo graus de fluorose dentária (Índice de Dean). Ribeirão Pires, São Paulo, Brasil, 2005.

\begin{tabular}{lrc}
\hline \multicolumn{1}{c}{ Grau de fluorose } & $\mathrm{n}^{\circ}$ & $\%$ \\
\hline Muito leve & 190 & 59,6 \\
Leve & 92 & 28,8 \\
Moderada & 29 & 9,1 \\
Severa & 8 & 2,5 \\
\hline Total & 319 & 100,0 \\
\hline
\end{tabular}

Tabela 9 - Número e porcentagem de casos segundo dentes parâmetros para classificação da fluorose dentária. Ribeirão Pires, São Paulo, Brasil, 2005.

\begin{tabular}{|c|c|c|c|c|}
\hline Dentes & \multicolumn{2}{|c|}{$\mathrm{n}^{0}$} & \multicolumn{2}{|c|}{$\%$} \\
\hline Todos & 225 & & 70,5 & \\
\hline Anteriores & 12 & & 3,7 & \\
\hline 11 & & 1 & & 0,3 \\
\hline 13 & & 9 & & 2,8 \\
\hline 22 & & 1 & & 0,3 \\
\hline 33 & & 1 & & 0,3 \\
\hline Posteriores & 82 & & 25,8 & \\
\hline 14 & & 52 & & 16,3 \\
\hline 15 & & 11 & & 3,5 \\
\hline 16 & & 3 & & 0,9 \\
\hline 17 & & 1 & & 0,3 \\
\hline 24 & & 10 & & 3,1 \\
\hline 25 & & 3 & & 0,9 \\
\hline 34 & & 2 & & 0,6 \\
\hline Total & 319 & & 100,0 & \\
\hline
\end{tabular}


A proporção de casos com graus de fluorose moderada e severa, onde o comprometimento do esmalte é representado pela sua totalidade, ou há presença de manchas ou perda de estrutura, foi de 11,6\% (Tabela 7)

Em relação aos dentes (Tabela 8), 25,8\% dos mais afetados foram dentes posteriores, destacando-se os pré-molares superiores $(23,8 \%)$.

Por outro lado, $74,2 \%$ dos dentes $(70,5 \%$ correspondente a todos os dentes, onde se incluem os anteriores, somados a 3,7\% somente dos dentes anteriores) representaram algum tipo de comprometimento estético.

\subsection{Percepção do comprometimento estético}

Em relação ao comprometimento estético provocado por manchas (Tabela 10), 49,9\% dos entrevistados observaram manchas nos dentes dos adolescentes. Esses dados indicaram que praticamente metade dos entrevistados tem a percepção das alterações com comprometimento estético, sendo que as manchas de cor branca representaram a maior proporção $(33,9 \%)$.

Tabela 10 - Número e porcentagem de entrevistados responsáveis por casos de fluorose dentária, segundo percepção de alterações nos dentes. Ribeirão Pires, São Paulo, Brasil, 2005.

\begin{tabular}{|c|c|c|c|c|}
\hline Alteração & & & \multicolumn{2}{|c|}{$\%$} \\
\hline Não & 122 & & 38,2 & \\
\hline Sim & 159 & & 49,9 & \\
\hline Branca & & 108 & & 33,9 \\
\hline Outra & & 51 & & 16,0 \\
\hline Não respondeu & 38 & & 11,9 & \\
\hline Total & 319 & & 100,0 & \\
\hline
\end{tabular}




\subsection{Grau de escolaridade e profissão dos pais}

A Tabela 11 mostra a distribuição de casos e controles segundo o grau de escolaridade do pai e o grau de escolaridade da mãe.

Tabela 11 - Porcentagem de casos e controles segundo grau de escolaridade do pai e grau de escolaridade da mãe. Ribeirão Pires, São Paulo, Brasil, 2005.

\begin{tabular}{|c|c|c|c|c|c|c|}
\hline \multirow{2}{*}{$\begin{array}{l}\text { Grau de } \\
\text { escolaridade }\end{array}$} & \multicolumn{3}{|c|}{ Pai } & \multicolumn{3}{|c|}{ Mãe } \\
\hline & $\mathrm{n}^{0}$ & $\begin{array}{c}\text { Casos } \\
\%\end{array}$ & $\begin{array}{c}\text { Controles } \\
\%\end{array}$ & $\mathrm{n}^{\circ}$ & $\begin{array}{c}\text { Casos } \\
\%\end{array}$ & $\begin{array}{c}\text { Controles } \\
\%\end{array}$ \\
\hline Nenhum & 14 & 57,1 & 42,9 & 10 & 60,0 & 40,0 \\
\hline $1^{\circ}$ grau incompleto & 200 & 58,0 & 42,0 & 214 & 63,6 & 36,4 \\
\hline $1^{\circ}$ grau completo & 94 & 67,0 & 33,0 & 85 & 55,3 & 44,7 \\
\hline $2^{\circ}$ grau incompleto & 38 & 73,7 & 26,3 & 44 & 61,4 & 38,6 \\
\hline $2^{2}$ grau completo & 99 & 62,6 & 37,4 & 117 & 63,2 & 36,8 \\
\hline Superior incompleto & 15 & 66,7 & 33,3 & 17 & 82,4 & 17,6 \\
\hline Superior completo & 15 & 80,0 & 20,0 & 13 & 76,9 & 23,1 \\
\hline Total & 475 & 62,9 & 37,1 & 500 & 62,8 & 37,2 \\
\hline
\end{tabular}

Pai: $\chi^{2}$ Pearson $=6,81 ; p=0,339$

Mãe: $\chi^{2}$ Pearson $=6,08 ; p=0,415$

Em relação à escolaridade do pai, foram observadas maiores proporções de casos a partir do $1^{\circ}$ grau completo, enquanto nas situações onde o pai não tem escolaridade ou não completou o $1^{\circ}$ grau, a diferença entre as proporções foi menor.

Em relação à escolaridade da mãe, observou-se maiores proporções de casos a partir do nível superior incompleto.

As distribuições de casos e controles em relação à profissão do pai e profissão da mãe estão apresentadas na Tabela 12 e na Tabela 13, respectivamente. 
Tabela 12 - Porcentagem de casos e controles segundo profissão do pai. Ribeirão Pires, São Paulo, Brasil, 2005.

\begin{tabular}{|c|c|c|c|}
\hline Profissão do pai & $\mathrm{n}^{0}$ & $\begin{array}{c}\text { Casos } \\
\%\end{array}$ & $\begin{array}{c}\text { Controles } \\
\%\end{array}$ \\
\hline Outras & 2 & 100,0 & - \\
\hline Gerente/supervisor & 5 & 80,0 & 20,0 \\
\hline Engenheiro/arquiteto & 6 & 83,3 & 16,7 \\
\hline Enfermeiro/nutricionista/farmacêutico & 1 & 100,0 & - \\
\hline Técnico física/química & 2 & 100,0 & - \\
\hline Técnico construção civil/edificações/obras & 1 & 100,0 & - \\
\hline Técnico eletrônica/fotônica & 3 & 66,7 & 33,3 \\
\hline Técnico metalmecânica & 1 & 100,0 & - \\
\hline Outros técnicos & 6 & 50,0 & 50,0 \\
\hline Técnico bioquímica/biotecnologia & 6 & 66,7 & 33,3 \\
\hline Outros técnicos nível médio & 4 & 100,0 & - \\
\hline $\begin{array}{l}\text { Bancário/economiário/escriturário/ } \\
\text { assistente/auxiliar administrativo }\end{array}$ & 5 & 60,0 & 40,0 \\
\hline $\begin{array}{l}\text { Atendimento público/caixa/despachante/ } \\
\text { recenseador }\end{array}$ & 5 & 80,0 & 20,0 \\
\hline Hotelaria/alimentação & 6 & 66,7 & 33,3 \\
\hline Administração/conservação/manutenção & 4 & 25,0 & 75,0 \\
\hline Serviços de saúde & 2 & 50,0 & 50,0 \\
\hline Embelezamento/cuidados pessoais & 1 & - & 100,0 \\
\hline Proteção/segurança & 20 & 70,0 & 30,0 \\
\hline Motorista (passageiros) & 24 & 75,0 & 25,0 \\
\hline Serviços diversos & 150 & 60,0 & 40,0 \\
\hline $\begin{array}{l}\text { Vendedor/comerciante/ambulante/caixeiro/ } \\
\text { camelô }\end{array}$ & 19 & 73,7 & 26,3 \\
\hline Agropecuária & 1 & 100,0 & - \\
\hline Operador máquina agropecuária/florestal & 1 & - & 100,0 \\
\hline Transformação metais & 14 & 28,6 & 71,4 \\
\hline Fabricação/instalação eletro-eletrônica & 1 & 100,0 & - \\
\hline $\begin{array}{l}\text { Indústria têxtil/curtimento/vestuário/ } \\
\text { artes gráficas }\end{array}$ & 1 & 100,0 & - \\
\hline Madeira/mobiliário & 8 & 25,0 & 75,0 \\
\hline Condutor robôs/veículos de carga & 26 & 34,6 & 65,4 \\
\hline $\begin{array}{l}\text { Indústria química/ } \\
\text { petroquímica/borracha/plástico }\end{array}$ & 2 & 50,0 & 50,0 \\
\hline Instalações/distribuição de energia & 7 & 14,3 & 85,7 \\
\hline Outras instalações agroindustriais & 53 & 45,3 & 54,7 \\
\hline Reparação/manutenção & 36 & 50,0 & 50,0 \\
\hline Total & 423 & 62,9 & 37,1 \\
\hline
\end{tabular}


Tabela 13 - Porcentagem de casos e controles segundo profissão da mãe.

Ribeirão Pires, São Paulo, Brasil, 2005.

\begin{tabular}{lrcc}
\hline \multicolumn{1}{c}{ Profissão da mãe } & no & $\begin{array}{c}\text { Casos } \\
\%\end{array}$ & $\begin{array}{c}\text { Controles } \\
\%\end{array}$ \\
\hline Outras & 290 & 61,4 & 38,6 \\
Dirigente/presidente & 1 & 100,0 & - \\
Gerente/supervisor & 1 & 100,0 & - \\
Professor educação infantil & 14 & 71,4 & 28,6 \\
Professor ensino fundamental & 8 & 87,5 & 12,5 \\
Pedagogo/orientador educacional & 1 & - & 100,0 \\
Técnico laboratórios/raios-X & 1 & 100,0 & - \\
Técnico bioquímica/biotecnologia & 1 & - & 100,0 \\
Outros técnicos nível médio & 3 & 100,0 & - \\
Bancário/economiário/escriturário/ & 8 & 25,0 & 75,0 \\
assistente/auxiliar administrativo & & & \\
Atendimento público/caixa/despachante/ & 11 & 63,6 & 36,4 \\
recenseador & & & \\
Serviços domésticos & 36 & 69,4 & 30,6 \\
Hotelaria/alimentação & 5 & 60,0 & 40,0 \\
Administração/conservação/manutenção & 3 & 66,7 & 33,3 \\
Serviços de saúde & 6 & 33,3 & 66,7 \\
Embelezamento/cuidados pessoais & 9 & 77,8 & 22,2 \\
Proteção/segurança & 3 & 66,7 & 33,3 \\
Serviços diversos & 63 & 60,3 & 39,7 \\
Vendedor/comerciante/ambulante/caixeiro/ & 22 & 63,6 & 36,4 \\
camelô & & & \\
Transformação metais & 1 & - & 100,0 \\
Outras instalações agroindustriais & 5 & 60,0 & 40,0 \\
\hline Total & 492 & 60,3 & 39,7 \\
\hline
\end{tabular}

Devido ao número elevado de categorias, tanto em relação à escolaridade (Tabela 11), quanto em relação à profissão dos pais (Tabela 12 e Tabela 13); houve necessidade de agrupamento sem comprometer sua interpretação (Tabela 35).

Para a escolaridade do pai e a escolaridade da mãe, optou-se por separar as categorias "sem escolaridade" e "primeiro grau incompleto" das demais categorias. Em relação à profissão do pai e à profissão da mãe, o 
agrupamento foi feito de acordo com a formação necessária para o desempenho da atividade.

\subsection{Aleitamento materno no primeiro ano de vida}

As médias relativas à duração do aleitamento materno durante 0 primeiro ano de vida estão apresentadas na Tabela 14. Como não houve diferença estatisticamente significativa na duração do aleitamento materno entre casos e controles, optou-se por estabelecer um ponto de corte aos 6 meses, criando-se as categorias de "1 a 6 meses" e de "7 a 12 meses" e testar associação com a ocorrência de fluorose dentária.

Feito o teste de associação com a presença de fluorose dentária, não foi observada associação estatisticamente significativa $\left(\chi^{2}=3,78 ; p=0,151\right)$.

Tabela 14 - Média, desvio padrão, mediana e quartis da duração do aleitamento materno (em meses) no primeiro ano de vida . Ribeirão Pires, São Paulo, Brasil, 2005.

\begin{tabular}{lllllllll}
$\begin{array}{l}\text { Duração do } \\
\text { aleitamento } \\
\text { materno } \\
\text { (meses) }\end{array}$ & $\mathrm{n}^{\circ}$ & $\bar{x}$ & d.p. & Q25 & Me & Q75 & $\mathrm{t}^{*}$ & $\mathrm{p}^{* *}$ \\
\hline Casos & 315 & 5,4 & 4,2 & 2,0 & 4,0 & 9,0 & 0,267 & 0,789 \\
Controles & 187 & 5,5 & 4,6 & 1,0 & 4,0 & 12,0 & & \\
* Valor do teste "t" de Student para amostras independentes. \\
** Probabilidade de rejeição da hipótese de nulidade.
\end{tabular}

\section{5. Água para ingestão e para preparo de alimentos}

As distribuições de casos e controles em função do tipo de água para consumo e para preparo de alimentos estão apresentadas na Tabela 15 e Tabela 16, respectivamente. 
Tabela 15 - Porcentagem de casos e controles segundo tipo de água ingerida e ciclo de vida. Ribeirão Pires, São Paulo, Brasil, 2005.

\begin{tabular}{|c|c|c|c|c|c|c|}
\hline $\begin{array}{l}\text { Ciclo de } \\
\text { vida }\end{array}$ & $\begin{array}{c}\text { Tipo de } \\
\text { água }\end{array}$ & $\mathrm{n}^{\circ}$ & $\begin{array}{c}\text { Casos } \\
\%\end{array}$ & $\begin{array}{c}\text { Controles } \\
\%\end{array}$ & $\begin{array}{c}\chi^{2} \\
\text { Pearson }\end{array}$ & $p$ \\
\hline $1^{0}$ ano de & Nenhuma & 29 & 69,0 & 31,0 & \multirow{8}{*}{6,38} & \multirow{8}{*}{0,382} \\
\hline \multirow{7}{*}{ vida } & Bica & 8 & 75,0 & 25,0 & & \\
\hline & Mina & 2 & 50,0 & 50,0 & & \\
\hline & Fonte & 32 & 65,6 & 34,4 & & \\
\hline & Poço & 43 & 46,5 & 53,5 & & \\
\hline & Outras & 2 & 50,0 & 50,0 & & \\
\hline & Encanada & 391 & 63,7 & 36,3 & & \\
\hline & Total & 507 & 62,7 & 37,3 & & \\
\hline \multirow{8}{*}{1 a 3 anos } & Nenhuma & 5 & 60,0 & 40,0 & \multirow{8}{*}{10,39} & \multirow{8}{*}{0,10} \\
\hline & Bica & 9 & 88,9 & 11,1 & & \\
\hline & Mina & 3 & 66,7 & 33,3 & & \\
\hline & Fonte & 27 & 59,3 & 40,7 & & \\
\hline & Poço & 40 & 42,5 & 57,5 & & \\
\hline & Outras & 2 & 50,0 & 50,0 & & \\
\hline & Encanada & 423 & 64,3 & 35,7 & & \\
\hline & Total & 509 & 62,7 & 37,3 & & \\
\hline \multirow[t]{8}{*}{4 a 6 anos } & Nenhuma & 1 & 100,0 & - & \multirow{8}{*}{16,17} & \multirow{8}{*}{0,013} \\
\hline & Bica & 10 & 70,0 & 30,0 & & \\
\hline & Mina & 2 & 50,0 & 50,0 & & \\
\hline & Fonte & 27 & 66,7 & 33,3 & & \\
\hline & Poço & 38 & 36,8 & 63,2 & & \\
\hline & Outras & 2 & 100,0 & - & & \\
\hline & Encanada & 429 & 64,8 & 35,2 & & \\
\hline & Total & 509 & 62,7 & 37,3 & & \\
\hline
\end{tabular}


Tabela 16 - Porcentagem de casos e controles segundo tipo de água para preparo de alimentos e ciclo de vida. Ribeirão Pires, São Paulo, Brasil, 2005.

\begin{tabular}{|c|c|c|c|c|c|c|}
\hline $\begin{array}{l}\text { Ciclo de } \\
\text { vida }\end{array}$ & $\begin{array}{l}\text { Tipo de } \\
\text { água }\end{array}$ & $\mathrm{n}^{0}$ & $\begin{array}{c}\text { Casos } \\
n\end{array}$ & $\begin{array}{c}\text { Controles } \\
\%\end{array}$ & $\begin{array}{c}\chi^{2} \\
\text { Pearson }\end{array}$ & $p$ \\
\hline $1^{\circ}$ ano de & Bica & 3 & 66,7 & 33,3 & \multirow{7}{*}{10,94} & \multirow{7}{*}{0,053} \\
\hline \multirow{6}{*}{ vida } & Mina & 3 & 33,3 & 66,7 & & \\
\hline & Fonte & 15 & 80,0 & 20,0 & & \\
\hline & Poço & 54 & 46,3 & 53,7 & & \\
\hline & Outras & 3 & 33,3 & 66,7 & & \\
\hline & Encanada & 428 & 64,5 & 35,5 & & \\
\hline & Total & 506 & 62,6 & 37,4 & & \\
\hline \multirow[t]{7}{*}{1 a 3 anos } & Bica & 1 & 100,0 & - & \multirow{7}{*}{10,63} & \multirow{7}{*}{$0,05 \varsigma$} \\
\hline & Mina & 3 & 66,7 & 33,3 & & \\
\hline & Fonte & 11 & 63,6 & 36,4 & & \\
\hline & Poço & 43 & 41,9 & 58,1 & & \\
\hline & Outras & 3 & 33,3 & 66,7 & & \\
\hline & Encanada & 447 & 64,9 & 35,1 & & \\
\hline & Total & 508 & 62,8 & 37,2 & & \\
\hline \multirow[t]{7}{*}{4 a 6 anos } & Bica & - & - & - & \multirow{7}{*}{18,79} & \multirow{7}{*}{0,001} \\
\hline & Mina & 2 & 50,0 & 50,0 & & \\
\hline & Fonte & 7 & 85,7 & 14,3 & & \\
\hline & Poço & 41 & 34,1 & 65,9 & & \\
\hline & Outras & 1 & - & 100,0 & & \\
\hline & Encanada & 458 & 65,1 & 34,9 & & \\
\hline & Total & 509 & 62,7 & 37,3 & & \\
\hline
\end{tabular}

Tanto para a água utilizada para ingestão (Tabela 15), quanto para a água utilizada no preparo de alimentos (Tabela 16); foi observada uma tendência de destaque das freqüências de água encanada entre os casos e de água de poço entre controles.

Como a ocorrência de fluorose dentária varia conforme o tempo de exposição, foi necessário analisar essas variáveis ao longo dos ciclos (Tabela 36). 


\subsection{Leite}

A distribuição de casos e controles em função do tipo de leite ingerido está apresentada na Tabela 17.

Tabela 17 - Porcentagem de casos e controles segundo tipo de leite ingerido e ciclo de vida. Ribeirão Pires, São Paulo, Brasil, 2005.

\begin{tabular}{|c|c|c|c|c|c|c|c|}
\hline \multirow{3}{*}{$\begin{array}{l}\begin{array}{l}\text { Ciclo de } \\
\text { vida }\end{array} \\
1^{\circ} \text { ano de } \\
\text { vida }\end{array}$} & \multicolumn{2}{|c|}{ Tipo de leite } & \multirow{2}{*}{$\begin{array}{c}\mathrm{n}^{\mathrm{o}} \\
85\end{array}$} & \multirow{2}{*}{$\begin{array}{c}\text { Casos } \\
\% \\
42,4\end{array}$} & \multirow{2}{*}{$\begin{array}{c}\text { Controles } \\
\begin{array}{c}\% \\
57,6\end{array}\end{array}$} & \multirow[t]{2}{*}{$\begin{array}{c}\chi^{2} \\
\text { Pearson }\end{array}$} & \multirow[t]{2}{*}{$\mathrm{p}$} \\
\hline & Nenhum & & & & & & \\
\hline & $\begin{array}{l}\text { Vaca sem } \\
\text { complemento }\end{array}$ & fórmula/sem & 23 & 43,5 & 56,5 & \multirow{6}{*}{5,85} & \multirow{6}{*}{0,441} \\
\hline & $\begin{array}{l}\text { Vaca sem } \\
\text { complemento }\end{array}$ & fórmula/com & 73 & 63,0 & 37,0 & & \\
\hline & & fórmula/sem & 53 & 60,4 & 39,6 & & \\
\hline & & fórmula/com & 125 & 67,2 & 32,8 & & \\
\hline & $\begin{array}{l}\text { Pó com fórmul } \\
\text { complemento }\end{array}$ & a/com e sem & 145 & 64,1 & 35,9 & & \\
\hline & Total & & 504 & 62,3 & 37,7 & & \\
\hline \multirow{7}{*}{$\begin{array}{l}1 \text { a } 3 \\
\text { anos }\end{array}$} & \multirow{5}{*}{$\begin{array}{l}\text { Nenhum } \\
\text { Vaca sem } \\
\text { complemento } \\
\text { Vaca sem } \\
\text { complemento } \\
\text { Pó sem } \\
\text { complemento } \\
\text { Pó sem } \\
\text { complemento }\end{array}$} & & 38 & 60,5 & 39,5 & \multirow{7}{*}{2,33} & \multirow{7}{*}{0,887} \\
\hline & & fórmula/sem & 113 & 64,6 & 35,4 & & \\
\hline & & fórmula/com & 162 & 63,0 & 37,0 & & \\
\hline & & fórmula/sem & 55 & 65,5 & 34,5 & & \\
\hline & & fórmula/com & 122 & 59,0 & 41,0 & & \\
\hline & $\begin{array}{l}\text { Pó com fórmul } \\
\text { complemento }\end{array}$ & a/com e sem & 15 & 66,7 & 33,3 & & \\
\hline & Total & & 505 & 62,6 & 37,4 & & \\
\hline \multirow{7}{*}{$\begin{array}{l}4 \text { a } 6 \\
\text { anos }\end{array}$} & \multirow{5}{*}{$\begin{array}{l}\text { Nenhum } \\
\text { Vaca sem } \\
\text { complemento } \\
\text { Vaca sem } \\
\text { complemento } \\
\text { Pó sem } \\
\text { complemento } \\
\text { Pó sem } \\
\text { complemento }\end{array}$} & & 55 & 47,3 & 52,7 & \multirow{7}{*}{5,80} & \multirow{7}{*}{0,326} \\
\hline & & fórmula/sem & 174 & 62,6 & 37,4 & & \\
\hline & & fórmula/com & 183 & 63,4 & 36,6 & & \\
\hline & & fórmula/sem & 45 & 71,1 & 28,9 & & \\
\hline & & fórmula/com & 46 & 65,2 & 34,8 & & \\
\hline & \multicolumn{2}{|c|}{$\begin{array}{l}\text { Pó com fórmula/com e sem } \\
\text { complemento }\end{array}$} & 3 & - & 100,0 & & \\
\hline & Total & & 506 & 62,5 & 37,5 & & \\
\hline
\end{tabular}


Não foi observada tendência na distribuição de casos e controles que necessitasse qualquer tipo de categorização.

\subsection{Chá}

$\mathrm{Na}$ Tabela 18 está apresentada a distribuição de casos e controles segundo tipo de chá ingerido. Foram considerados chás verdes aqueles cujos entrevistados citaram a utilização de folhas.

As infusões foram aquelas em que os entrevistados citaram a utilização de sachês e, como chá preto, quando foi referido, independente de ser sachê ou folha.

Da mesma forma que no leite ingerido, não foi observada tendência na distribuição de casos e controles que merecesse qualquer tipo de categorização. Apenas a categoria "chá verde" apresentou uma inversão na distribuição entre o primeiro e terceiro ciclos.

Tabela 18 - Porcentagem de casos e controles segundo tipo de chá ingerido e ciclo de vida. Ribeirão Pires, São Paulo, Brasil, 2004.

\begin{tabular}{|c|c|c|c|c|c|c|}
\hline $\begin{array}{l}\text { Ciclo de } \\
\text { vida }\end{array}$ & Tipo de chá & $\mathrm{n}^{0}$ & $\begin{array}{c}\text { Casos } \\
\%\end{array}$ & $\begin{array}{c}\text { Controles } \\
\%\end{array}$ & $\begin{array}{c}\chi^{2} \\
\text { Pearson }\end{array}$ & $p$ \\
\hline $1^{0}$ ano & Nenhum & 56 & 62,5 & 37,5 & \multirow{5}{*}{2,62} & \multirow{5}{*}{0,454} \\
\hline \multirow[t]{4}{*}{ de vida } & Verde & 16 & 43,8 & 56,2 & & \\
\hline & Infusão & 431 & 63,6 & 36,4 & & \\
\hline & Preto & 3 & 66,7 & 33,3 & & \\
\hline & Total & 506 & 62,8 & 37,2 & & \\
\hline 1 a 3 & Nenhum & 238 & 63,9 & 36,1 & \multirow{5}{*}{0,93} & \multirow{5}{*}{0,819} \\
\hline \multirow{4}{*}{ anos } & Verde & 17 & 52,9 & 47,1 & & \\
\hline & Infusão & 247 & 61,9 & 38,1 & & \\
\hline & Preto & 6 & 66,7 & 33,3 & & \\
\hline & Total & 508 & 62,6 & 37,4 & & \\
\hline 4 a 6 & Nenhum & 291 & 64,9 & 35,1 & \multirow{5}{*}{2,17} & \multirow{5}{*}{0,537} \\
\hline \multirow{4}{*}{ anos } & Verde & 14 & 71,4 & 28,6 & & \\
\hline & Infusão & 193 & 59,1 & 40,9 & & \\
\hline & Preto & 8 & 62,5 & 37,5 & & \\
\hline & Total & 506 & 62,8 & 37,2 & & \\
\hline
\end{tabular}




\subsection{Recipiente para preparo de alimentos}

Na Tabela 19 está apresentada a distribuição de casos e controles segundo tipo de recipiente utilizado no preparo de alimentos.

Pode ser observado que a categoria "alumínio" destaca-se com as maiores freqüências em todos os ciclos, porém, não houve situação que indicasse a necessidade de qualquer tipo de categorização, pois não foi observada tendência na distribuição de casos e controles.

Tabela 19 - Porcentagem de casos e controles segundo tipo de recipiente para preparo de alimentos e ciclo de vida. Ribeirão Pires, São Paulo, Brasil, 2005.

\begin{tabular}{|c|c|c|c|c|c|c|}
\hline $\begin{array}{l}\text { Ciclo } \\
\text { de vida }\end{array}$ & Tipo de recipiente & $\mathrm{n}^{0}$ & $\begin{array}{c}\text { Casos } \\
\%\end{array}$ & $\begin{array}{c}\text { Controles } \\
\%\end{array}$ & $\begin{array}{c}\chi^{2} \\
\text { Pearson }\end{array}$ & $p$ \\
\hline $1^{0}$ ano & Alumínio & 461 & 64,0 & 36,0 & \multirow{5}{*}{3,75} & \multirow{5}{*}{0,290} \\
\hline \multirow[t]{4}{*}{ de vida } & $\begin{array}{l}\text { Cobre/ } \\
\text { ferro/vidro }\end{array}$ & 5 & 60,0 & 40,0 & & \\
\hline & Pedra & 4 & 50,0 & 50,0 & & \\
\hline & $\begin{array}{l}\text { Anti-aderente/ } \\
\text { esmaltado/barro }\end{array}$ & 37 & 48,6 & 51,4 & & \\
\hline & Total & 507 & 62,7 & 37,3 & & \\
\hline \multirow{5}{*}{$\begin{array}{l}1 \text { a } 3 \\
\text { anos }\end{array}$} & Alumínio & 434 & 63,6 & 36,4 & \multirow{5}{*}{2,83} & \multirow{5}{*}{0,419} \\
\hline & $\begin{array}{l}\text { Cobre/ } \\
\text { ferro/vidro }\end{array}$ & 6 & 66,7 & 33,3 & & \\
\hline & Pedra & 8 & 75,0 & 25,0 & & \\
\hline & $\begin{array}{l}\text { Anti-aderente/ } \\
\text { esmaltado/barro }\end{array}$ & 58 & 53,4 & 46,6 & & \\
\hline & Total & 506 & 62,6 & 37,4 & & \\
\hline 4 a 6 & Alumínio & 396 & 63,1 & 36,9 & \multirow{5}{*}{0,804} & \multirow{5}{*}{0,848} \\
\hline \multirow[t]{4}{*}{ anos } & $\begin{array}{l}\text { Cobre/ } \\
\text { ferro/vidro }\end{array}$ & 10 & 30,0 & 70,0 & & \\
\hline & Pedra & 10 & 30,0 & 70,0 & & \\
\hline & $\begin{array}{l}\text { Anti-aderente/ } \\
\text { esmaltado/barro }\end{array}$ & 87 & 40,2 & 59,8 & & \\
\hline & Total & 503 & 62,8 & 37,2 & & \\
\hline
\end{tabular}




\subsection{Filtro para água}

Na Tabela 20 está apresentada a distribuição de casos e controles segundo uso de filtro para água. Houve semelhança na distribuição entre casos e controles no segundo e terceiro ciclos e uma pequena diferença no primeiro ciclo. Foi necessário avaliar se a continuidade da exposição poderia indicar alguma associação (Tabela 36).

Tabela 20 - Porcentagem de casos e controles segundo uso de filtro para água e ciclo de vida. Ribeirão Pires, São Paulo, Brasil, 2005.

\begin{tabular}{|c|c|c|c|c|c|c|}
\hline $\begin{array}{l}\text { Ciclo de } \\
\text { vida }\end{array}$ & $\begin{array}{l}\text { Uso de } \\
\text { filtro }\end{array}$ & $\mathrm{n}^{\circ}$ & $\begin{array}{c}\text { Casos } \\
\%\end{array}$ & $\begin{array}{c}\text { Controles } \\
\%\end{array}$ & $\begin{array}{c}\chi^{2} \\
\text { Pearson }\end{array}$ & $p$ \\
\hline $1^{0}$ ano de & Não & 143 & 60,1 & 39,9 & \multirow{3}{*}{0,57} & \multirow{3}{*}{0,451} \\
\hline \multirow[t]{2}{*}{ vida } & Sim & 364 & 63,7 & 36,3 & & \\
\hline & Total & 507 & 62,7 & 37,3 & & \\
\hline \multirow[t]{3}{*}{1 a 3 anos } & Não & 117 & 57,3 & 42,7 & \multirow{3}{*}{1,85} & \multirow{3}{*}{0,174} \\
\hline & Sim & 391 & 64,2 & 35,8 & & \\
\hline & Total & 508 & 63,4 & 36,6 & & \\
\hline \multirow[t]{3}{*}{4 a 6 anos } & Não & 131 & 58,8 & 41,2 & \multirow{3}{*}{2,17} & \multirow{3}{*}{0,272} \\
\hline & Sim & 374 & 64,2 & 35,8 & & \\
\hline & Total & 505 & 62,8 & 37,2 & & \\
\hline
\end{tabular}

\subsection{Sucos e bebidas}

As distribuições de casos e controles segundo consumo de sucos e de bebidas estão apresentadas respectivamente na Tabela 21 e na Tabela 22.

Quando se coletou a informação sobre bebidas, os sucos naturais foram considerados bebidas sem flúor.

Em relação aos sucos, houve semelhança na distribuição de casos e controles, o que não necessitou maior exploração das categorias da variável no sentido de identificar associações.

Em relação às bebidas, a grande proporção da categoria "não identificada", inviabilizou a avaliação de qualquer tendência na exposição. 
Tabela 21 - Porcentagem de casos e controles segundo tipo de suco ingerido e ciclo de vida. Ribeirão Pires, São Paulo, Brasil, 2005.

\begin{tabular}{|c|c|c|c|c|c|c|}
\hline $\begin{array}{c}\text { Ciclo de } \\
\text { vida }\end{array}$ & Tipo de suco & $\mathrm{n}^{0}$ & $\begin{array}{c}\text { Casos } \\
\%\end{array}$ & $\begin{array}{c}\text { Controles } \\
\%\end{array}$ & $\begin{array}{c}\chi^{2} \\
\text { Pearson }\end{array}$ & $p$ \\
\hline $1^{\circ}$ ano de & Nenhum & 373 & 63,8 & 36,2 & \multirow{5}{*}{0,76} & \multirow{5}{*}{0,860} \\
\hline \multirow[t]{4}{*}{ vida } & Sem água & 6 & 66,7 & 33,3 & & \\
\hline & Com água & 114 & 59,6 & 40,4 & & \\
\hline & Não identificado & 12 & 66,7 & 33,3 & & \\
\hline & Total & 505 & 63,0 & 37,0 & & \\
\hline 1 a 3 & Nenhum & 199 & 63,8 & 36,2 & \multirow{5}{*}{2,91} & \multirow{5}{*}{0,405} \\
\hline \multirow[t]{4}{*}{ anos } & Sem água & 6 & 66,7 & 33,3 & & \\
\hline & Com água & 230 & 65,2 & 34,8 & & \\
\hline & Não identificado & 65 & 53,8 & 46,2 & & \\
\hline & Total & 500 & 63,2 & 36,8 & & \\
\hline
\end{tabular}

Tabela 22 - Porcentagem de casos e controles segundo tipo de bebida ingerida e ciclo de vida. Ribeirão Pires, São Paulo, Brasil, 2005.

\begin{tabular}{|c|c|c|c|c|c|c|}
\hline \multirow[t]{2}{*}{$\begin{array}{l}\text { Ciclo de } \\
\text { vida }\end{array}$} & \multirow[t]{2}{*}{ Tipo de bebida } & \multirow[t]{2}{*}{$\mathrm{n}^{0}$} & Casos & $\begin{array}{c}\text { Controle } \\
\mathrm{S}\end{array}$ & \multirow[t]{2}{*}{$\begin{array}{c}\chi^{2} \\
\text { Pearson }\end{array}$} & \multirow[t]{2}{*}{$\mathrm{p}$} \\
\hline & & & $\%$ & $\%$ & & \\
\hline 1 a 3 & Nenhum & 148 & 59,5 & 40,5 & \multirow{4}{*}{0,18} & \multirow{4}{*}{0,919} \\
\hline \multirow[t]{3}{*}{ anos } & Sem flúor & 3 & 66,7 & 33,3 & & \\
\hline & Não identificada & 351 & 63,5 & 36,5 & & \\
\hline & Total & 502 & 62,4 & 37,6 & & \\
\hline 4 a 6 & Nenhum & 70 & 55,7 & 44,3 & \multirow{4}{*}{2,86} & \multirow{4}{*}{0,413} \\
\hline \multirow[t]{3}{*}{ anos } & Sem flúor & 1 & 100,0 & - & & \\
\hline & Não identificada & 437 & 64,1 & 35,9 & & \\
\hline & Total & 508 & 62,8 & 37,2 & & \\
\hline
\end{tabular}




\subsection{Peixes}

Na Tabela 23 está apresentada a distribuição de casos e controles em função do tipo de peixe ingerido nos segundo e terceiro ciclos.

Tabela 23 - Porcentagem de casos e controles segundo tipo de peixe consumido e ciclo de vida. Ribeirão Pires, São Paulo, Brasil, 2005.

\begin{tabular}{|c|c|c|c|c|c|c|}
\hline $\begin{array}{l}\text { Ciclo de } \\
\text { vida }\end{array}$ & Tipo de peixe & $\mathrm{n}^{0}$ & $\begin{array}{c}\text { Casos } \\
\%\end{array}$ & $\begin{array}{c}\text { Controles } \\
\%\end{array}$ & $\begin{array}{c}\chi^{2} \\
\text { Pearson }\end{array}$ & $p$ \\
\hline \multirow[t]{5}{*}{1 a 3 anos } & Nenhum & 189 & 61,9 & 38,1 & \multirow{5}{*}{1,91} & \multirow{5}{*}{0,592} \\
\hline & Água doce & 37 & 59,5 & 40,5 & & \\
\hline & Água salgada & 199 & 65,8 & 34,2 & & \\
\hline & Outros & 64 & 62,5 & 37,5 & & \\
\hline & Total & 489 & 63,4 & 36,6 & & \\
\hline \multirow[t]{5}{*}{4 a 6 anos } & Nenhum & 137 & 62,0 & 38,0 & \multirow{5}{*}{3,57} & \multirow{5}{*}{0,312} \\
\hline & Água doce & 46 & 60,9 & 39,1 & & \\
\hline & Água salgada & 236 & 66,1 & 33,9 & & \\
\hline & Outros & 79 & 54,4 & 45,6 & & \\
\hline & Total & 498 & 62,7 & 37,3 & & \\
\hline
\end{tabular}

Houve semelhança de distribuição nos dois ciclos, não sendo observada tendência na distribuição de casos e controles que indicasse a necessidade de qualquer tipo de categorização.

\subsection{Medicamentos}

As distribuições de casos e controles segundo utilização de medicamentos durante a gestação (Tabela 24) e nos três ciclos de vida (Tabela 25) estão apresentadas a seguir.

$\mathrm{Na}$ gestação e dois primeiros ciclos as distribuições foram semelhantes e apresentaram diferenças quando comparadas com o terceiro ciclo, que teve uma pequena diferença quando foram observadas as categorias "nenhum" e "com flúor". 
Da mesma forma que a exposição à água, como o fenômeno que está associado à continuidade da exposição, foi necessária uma análise utilizando a combinação dos ciclos.

Tabela 24 - Porcentagem de casos e controles segundo tipo de medicamento utilizado na gestação. Ribeirão Pires, São Paulo, Brasil, 20054.

\begin{tabular}{lccc}
\hline \multicolumn{1}{r}{ Tipo de medicamento } & $\mathrm{n}^{\circ}$ & $\begin{array}{c}\text { Casos } \\
\%\end{array}$ & $\begin{array}{c}\text { Controles } \\
\%\end{array}$ \\
\hline Nenhum & 165 & 64,2 & 35,8 \\
Sem flúor & 138 & 56,5 & 43,5 \\
Não identificado & 121 & 66,1 & 33,9 \\
Com flúor & 45 & 68,9 & 31,1 \\
\hline Total & 469 & 62,9 & 37,1 \\
\hline$\chi^{2}$ Pearson $=3,76 \mathrm{p}=0,288$ & & &
\end{tabular}

Tabela 25 - Porcentagem de casos e controles segundo tipo de medicamento utilizado e ciclo de vida. Ribeirão Pires, São Paulo, Brasil, 2005.

\begin{tabular}{|c|c|c|c|c|c|c|}
\hline $\begin{array}{l}\text { Ciclo de } \\
\text { vida }\end{array}$ & $\begin{array}{c}\text { Tipo de } \\
\text { medicamento }\end{array}$ & $\mathrm{n}^{\circ}$ & $\begin{array}{c}\text { Casos } \\
\%\end{array}$ & $\begin{array}{c}\text { Controles } \\
\%\end{array}$ & $\begin{array}{c}\chi^{2} \\
\text { Pearson }\end{array}$ & $p$ \\
\hline \multirow{5}{*}{$\begin{array}{l}1^{0} \text { ano de } \\
\text { vida }\end{array}$} & Nenhum & 183 & 62,8 & 37,2 & \multirow{5}{*}{0,04} & \multirow{5}{*}{0,998} \\
\hline & Sem flúor & 224 & 62,5 & 37,5 & & \\
\hline & Não identificado & 57 & 63,2 & 36,8 & & \\
\hline & Com flúor & 31 & 61,3 & 38,7 & & \\
\hline & Total & 495 & 62,6 & 37,4 & & \\
\hline 1 a 3 & Nenhum & 270 & 62,6 & 37,4 & \multirow{5}{*}{1,88} & \multirow{5}{*}{0,598} \\
\hline \multirow[t]{4}{*}{ anos } & Sem flúor & 148 & 64,9 & 35,1 & & \\
\hline & Não identificado & 43 & 53,5 & 46,5 & & \\
\hline & Com flúor & 28 & 60,7 & 39,3 & & \\
\hline & Total & 489 & 62,4 & 37,6 & & \\
\hline 4 a 6 & Nenhum & 324 & 60,5 & 39,5 & \multirow{5}{*}{4,22} & \multirow{5}{*}{0,239} \\
\hline \multirow[t]{4}{*}{ anos } & Sem flúor & 117 & 62,4 & 37,6 & & \\
\hline & Não identificado & 40 & 70,0 & 30,0 & & \\
\hline & Com flúor & 13 & 84,6 & 15,4 & & \\
\hline & Total & 494 & 62,3 & 37,7 & & \\
\hline
\end{tabular}


Após a categorização da variável tipo de medicamento, encontrou-se 3 casos em 489 que se expuseram nos três ciclos ( $1^{-}$ano, 1 a 3 anos e 4 a 6 anos), 6 casos que se expuseram nos primeiro e segundo ciclos ( $1^{\circ}-$ ano e 1 a 3 anos); e 1 caso que se expôs nos segundo e terceiro ciclos ( 1 a 3 anos e 4 a 6 anos). Por esse motivo, essa variável não foi incluída no modelo de regressão múltipla.

\subsection{Responsável pela indicação de medicamentos}

As freqüências de casos e controles segundo responsável pela indicação de medicamentos por ciclo estão apresentadas na Tabela 26.

Tabela 26 - Porcentagem de casos e controles segundo responsável pela indicação de medicamentos e ciclo de vida. Ribeirão Pires, São Paulo, Brasil, 2005.

\begin{tabular}{|c|c|c|c|c|c|c|}
\hline $\begin{array}{l}\text { Ciclo de } \\
\text { vida }\end{array}$ & $\begin{array}{l}\text { Responsável pela } \\
\text { indicação }\end{array}$ & $\mathrm{n}^{\circ}$ & $\begin{array}{c}\text { Casos } \\
\%\end{array}$ & $\begin{array}{c}\text { Controles } \\
\% \\
\end{array}$ & $\begin{array}{c}\chi^{2} \\
\text { Pearson }\end{array}$ & $\mathrm{p}$ \\
\hline $1^{0}$ ano & Não usou & 179 & 63,7 & 36,3 & \multirow{5}{*}{1,74} & \multirow{5}{*}{0,782} \\
\hline de vida & Médico* & 243 & 60,5 & 39,5 & & \\
\hline & Outro profissional ${ }^{* *}$ & 10 & 50,0 & 50,0 & & \\
\hline & Leigo & 7 & 57,1 & 42,9 & & \\
\hline & Total & 439 & 61,5 & 38,5 & & \\
\hline \multirow{5}{*}{$\begin{array}{l}1 \text { a } 3 \\
\text { anos }\end{array}$} & Não usou & 269 & 62,1 & 37,9 & \multirow{5}{*}{1,89} & \multirow{5}{*}{0,595} \\
\hline & Médico & 159 & 62,3 & 37,7 & & \\
\hline & Outro profissional ${ }^{* *}$ & 17 & 47,1 & 52,9 & & \\
\hline & Leigo & 13 & 69,2 & 30,8 & & \\
\hline & Total & 458 & 61,8 & 38,2 & & \\
\hline \multirow{5}{*}{$\begin{array}{l}4 \text { a } 6 \\
\text { anos }\end{array}$} & Não usou & 325 & 60,6 & 39,4 & \multirow{5}{*}{8,74} & \multirow{5}{*}{0,033} \\
\hline & Médico & 124 & 68,5 & 31,5 & & \\
\hline & Outro profissional ${ }^{* *}$ & 11 & 27,3 & 72,7 & & \\
\hline & Leigo & 8 & 75,0 & 25,0 & & \\
\hline & Total & 468 & 62,2 & 37,8 & & \\
\hline
\end{tabular}

* Dos médicos, houve apenas uma menção a ginecologista no primeiro ciclo.

** Foram incluídas menções relativas a profissionais de saúde não credenciados para prescrição de medicamentos (enfermeiros, farmacêuticos, entre outros). 
Não foi identificada tendência na distribuição que necessitasse de combinações de categorias.

\subsection{Produtos para bochechos domésticos}

Na Tabela 27 está apresentada a distribuição de casos e controles segundo tipo de produto utilizado para bochecho doméstico em cada ciclo de vida.

Nos três ciclos, houve uma concentração das freqüências na categoria "nenhum", não havendo a necessidade de qualquer tipo de combinação de categorias (Tabela 38).

Tabela 27 - Porcentagem de casos e controles segundo tipo de produto utilizado para bochecho doméstico e ciclo de vida. Ribeirão Pires, São Paulo, Brasil, 2005.

\begin{tabular}{|c|c|c|c|c|c|c|}
\hline $\begin{array}{l}\text { Ciclo de } \\
\text { vida }\end{array}$ & Tipo de produto & $\mathrm{n}^{0}$ & $\begin{array}{c}\text { Casos } \\
\%\end{array}$ & $\begin{array}{c}\text { Controles } \\
\%\end{array}$ & $\begin{array}{c}\chi^{2} \\
\text { Pearson }\end{array}$ & $p$ \\
\hline $1 \stackrel{0}{a}$ ano & Nenhum & 477 & 61,2 & 38,8 & \multirow{5}{*}{6,95} & \multirow{5}{*}{0,074} \\
\hline \multirow{4}{*}{ de vida } & Sem flúor & 5 & 80,0 & 20,0 & & \\
\hline & Não identificado & 6 & 100,0 & - & & \\
\hline & Com flúor & 4 & 100,0 & - & & \\
\hline & Total & 492 & 62,2 & 37,8 & & \\
\hline \multirow{5}{*}{$\begin{array}{l}1 \text { a } 3 \\
\text { anos }\end{array}$} & Nenhum & 479 & 62,6 & 37,4 & \multirow{5}{*}{9,35} & \multirow{5}{*}{0,025} \\
\hline & Sem flúor & 2 & 50,0 & 50,0 & & \\
\hline & Não identificado & 7 & 100,0 & - & & \\
\hline & Com flúor & 3 & - & 100,0 & & \\
\hline & Total & 491 & 62,7 & 37,3 & & \\
\hline \multirow{5}{*}{$\begin{array}{l}4 \text { a } 6 \\
\text { anos }\end{array}$} & Nenhum & 442 & 62,0 & 38,0 & \multirow{5}{*}{3,77} & \multirow{5}{*}{0,287} \\
\hline & Sem flúor & 13 & 53,8 & 46,2 & & \\
\hline & Não identificado & 25 & 80,0 & 20,0 & & \\
\hline & Com flúor & 15 & 60,0 & 40,0 & & \\
\hline & Total & 495 & 62,6 & 37,4 & & \\
\hline
\end{tabular}




\subsection{Tipo de dentifrício}

Na Tabela 28 está apresentada a distribuição de casos e controles segundo tipo de dentifrício utilizado por ciclo de vida.

Tabela 28 - Porcentagem de casos e controles segundo tipo de dentifrício utilizado e ciclo de vida. Ribeirão Pires, São Paulo, Brasil, 2005.

\begin{tabular}{|c|c|c|c|c|c|c|}
\hline $\begin{array}{l}\text { Ciclo de } \\
\text { vida }\end{array}$ & Tipo de dentifrício & $\mathrm{n}^{\circ}$ & $\begin{array}{c}\text { Casos } \\
\%\end{array}$ & $\begin{array}{c}\text { Controles } \\
\%\end{array}$ & $\begin{array}{c}\chi^{2} \\
\text { Pearson }\end{array}$ & $\mathrm{p}$ \\
\hline $1^{\circ}$ ano & Nenhum & 325 & 63,4 & 36,6 & \multirow{5}{*}{1,28} & \multirow{5}{*}{0,735} \\
\hline \multirow{4}{*}{ de vida } & Sem flúor & 8 & 50,0 & 50,0 & & \\
\hline & Não identificado & 34 & 55,9 & 44,1 & & \\
\hline & Com flúor & 139 & 62,6 & 37,4 & & \\
\hline & Total & 506 & 62,5 & 37,5 & & \\
\hline \multirow{5}{*}{$\begin{array}{l}1 \text { a } 3 \\
\text { anos }\end{array}$} & Nenhum & 35 & 60,0 & 40,0 & \multirow{5}{*}{2,49} & \multirow{5}{*}{0,477} \\
\hline & Sem flúor & 6 & 33,3 & 66,7 & & \\
\hline & Não identificado & 54 & 61,1 & 38,9 & & \\
\hline & Com flúor & 411 & 63,5 & 36,5 & & \\
\hline & Total & 506 & 62,6 & 62,6 & & \\
\hline \multirow{5}{*}{$\begin{array}{l}4 \text { a } 6 \\
\text { anos }\end{array}$} & Nenhum & 7 & 14,3 & 85,7 & \multirow{5}{*}{8,48} & \multirow{5}{*}{0,037} \\
\hline & Sem flúor & 9 & 55,6 & 44,4 & & \\
\hline & Não identificado & 48 & 56,2 & 43,8 & & \\
\hline & Com flúor & 444 & 64,2 & 35,8 & & \\
\hline & Total & 508 & 62,6 & 37,4 & & \\
\hline
\end{tabular}

Observou-se uma associação estatisticamente significativa no terceiro ciclo $\left(\chi^{2}=8,48 ; p=0,037\right)$ entre a não utilização de dentifrícios e a ausência de fluorose dentária, quando comparada com a presença de fluorose dentária e a utilização de dentifrício com flúor.

Da mesma forma que a exposição à água e medicamentos, foi necessária uma análise utilizando a combinação dos ciclos, pois a fluorose dentária está associada à continuidade da exposição (Tabela 37). 


\subsection{Quantidade de dentifrício}

Na Tabela 29 estão apresentadas as freqüências de casos e controles segundo quantidade de dentifrício utilizada por ciclo de vida. Foi observada a necessidade de se estabelecer a dose de risco de dentifrício para cada ciclo e a continuidade da exposição (Tabela 37).

Tabela 29 - Porcentagem de casos e controles segundo quantidade de dentifrício utilizada (em g) e ciclo de vida. Ribeirão Pires, São Paulo, Brasil, 2005.

\begin{tabular}{|c|c|c|c|c|c|c|}
\hline $\begin{array}{l}\text { Ciclo de } \\
\text { vida }\end{array}$ & $\begin{array}{l}\text { Quantidade de } \\
\text { dentifrício }(\mathrm{g})\end{array}$ & $\mathrm{n}^{\circ}$ & $\begin{array}{c}\text { Casos } \\
\%\end{array}$ & $\begin{array}{c}\text { Controles } \\
\%\end{array}$ & $\begin{array}{c}\chi^{2} \\
\text { Pearson }\end{array}$ & $p$ \\
\hline \multirow{8}{*}{$\begin{array}{l}1^{0} \text { ano } \\
\text { de vida }\end{array}$} & Nenhuma & 325 & 63,4 & 36,6 & \multirow{8}{*}{5,79} & \multirow{8}{*}{$0,44 \varepsilon$} \\
\hline & $0,11 \mathrm{~g}$ & 47 & 53,2 & 46,8 & & \\
\hline & $0,25 \mathrm{~g}$ & 27 & 74,1 & 25,9 & & \\
\hline & $0,50 \mathrm{~g}$ & 59 & 55,9 & 44,1 & & \\
\hline & $0,75 \mathrm{~g}$ & 28 & 64,3 & 35,7 & & \\
\hline & $1,00 \mathrm{~g}$ & 6 & 83,3 & 16,7 & & \\
\hline & $+1,00 \mathrm{~g}$ & 9 & 55,6 & 44,4 & & \\
\hline & Total & 501 & 62,3 & 37,7 & & \\
\hline \multirow{8}{*}{$\begin{array}{l}1 \text { a } 3 \\
\text { anos }\end{array}$} & Nenhuma & 35 & 60,0 & 40,0 & \multirow{8}{*}{8,48} & \multirow{8}{*}{0,183} \\
\hline & $0,11 \mathrm{~g}$ & 62 & 66,1 & 33,9 & & \\
\hline & $0,25 \mathrm{~g}$ & 57 & 70,2 & 29,8 & & \\
\hline & $0,50 \mathrm{~g}$ & 127 & 56,7 & 43,3 & & \\
\hline & $0,75 \mathrm{~g}$ & 111 & 69,4 & 30,6 & & \\
\hline & $1,00 \mathrm{~g}$ & 54 & 63,0 & 37,0 & & \\
\hline & $+1,00 \mathrm{~g}$ & 51 & 60,0 & 40,0 & & \\
\hline & Total & 497 & 66,1 & 33,9 & & \\
\hline \multirow{8}{*}{$\begin{array}{l}4 \text { a } 6 \\
\text { anos }\end{array}$} & Nenhuma & 7 & 14,3 & 85,7 & \multirow{8}{*}{13,93} & \multirow{8}{*}{0,030} \\
\hline & $0,11 \mathrm{~g}$ & 17 & 76,5 & 23,5 & & \\
\hline & $0,25 \mathrm{~g}$ & 41 & 73,2 & 26,8 & & \\
\hline & $0,50 \mathrm{~g}$ & 63 & 52,4 & 47,6 & & \\
\hline & $0,75 \mathrm{~g}$ & 159 & 64,8 & 35,2 & & \\
\hline & $1,00 \mathrm{~g}$ & 104 & 58,7 & 41,3 & & \\
\hline & $+1,00 \mathrm{~g}$ & 99 & 62,6 & 37,4 & & \\
\hline & Total & 490 & 61,8 & 38,2 & & \\
\hline
\end{tabular}




\subsection{Responsável pela colocação de dentifrício}

A distribuição de casos e controles em função do responsável pela colocação do dentifrício em cada ciclo de vida está apresentada na Tabela 30.

Observou-se uma associação estatisticamente significativa $\left(\chi^{2}=21,11\right.$; $p=0,000$ ) entre a criança como responsável pela colocação quando comparada com a categoria "nenhum" Como há freqüências baixas em algumas categorias, considerou-se adequado isolar a criança como responsável pela colocação do dentifrício no terceiro ciclo e a das demais categorias e avaliar a continuidade dessa exposição entre o segundo e terceiro ciclo (em cada um deles ou em ambos) (Tabela 37).

Tabela 30 - Porcentagem de casos e controles segundo responsável pela colocação de dentifrício e ciclo de vida. Ribeirão Pires, São Paulo, Brasil, 2005.

\begin{tabular}{|c|c|c|c|c|c|c|}
\hline $\begin{array}{c}\text { Ciclo } \\
\text { de vida }\end{array}$ & Responsável & $\mathrm{n}^{\circ}$ & $\begin{array}{c}\text { Casos } \\
\%\end{array}$ & $\begin{array}{c}\text { Controles } \\
\%\end{array}$ & $\begin{array}{c}\chi^{2} \\
\text { Pearson }\end{array}$ & $p$ \\
\hline $1^{0}$ ano & Não usava & 325 & 63,4 & 36,6 & \multirow{5}{*}{2,17} & \multirow{5}{*}{0,704} \\
\hline \multirow{4}{*}{ de vida } & Mãe & 166 & 61,4 & 38,6 & & \\
\hline & Pai + responsável & 4 & 50,0 & 50,0 & & \\
\hline & Cuidador & 11 & 54,5 & 45,5 & & \\
\hline & Total & 506 & 62,5 & 37,5 & & \\
\hline \multirow{6}{*}{$\begin{array}{l}1 \text { a } 3 \\
\text { anos }\end{array}$} & Não usava & 35 & 60,0 & 40,0 & \multirow{6}{*}{8,38} & \multirow{6}{*}{0,136} \\
\hline & Mãe & 335 & 64,2 & 35,8 & & \\
\hline & Pai + responsável & 30 & 63,3 & 36,7 & & \\
\hline & Cuidador & 33 & 45,5 & 54,5 & & \\
\hline & Criança & 73 & 64,4 & 35,6 & & \\
\hline & Total & 506 & 62,6 & 37,4 & & \\
\hline \multirow{6}{*}{$\begin{array}{l}4 \text { a } 6 \\
\text { anos }\end{array}$} & Não usava & 7 & 14,3 & 85,7 & \multirow{6}{*}{21,11} & \multirow{6}{*}{0,000} \\
\hline & Mãe & 179 & 58,7 & 41,3 & & \\
\hline & Pai + responsável & 18 & 55,6 & 44,4 & & \\
\hline & Cuidador & 23 & 34,8 & 65,2 & & \\
\hline & Criança & 278 & 69,1 & 30,9 & & \\
\hline & Total & 505 & 62,6 & 37,4 & & \\
\hline
\end{tabular}




\subsection{Tamanho da cabeça da escova de dentes}

Na Tabela 31 está apresentada a distribuição de casos e controles segundo tamanho da cabeça da escova de dentes em cada ciclo de vida.

Apenas no terceiro ciclo houve uma associação próxima da significância estatística. Considerou-se adequado Devido ao número de combinar todas as freqüências de escovas pequenas $(P)$, de escovas médias (M) e de escovas grandes (G), por ciclo (Tabela 37).

Tabela 31 - Porcentagem de casos e controles segundo tamanho da cabeça da escova de dentes e ciclo de vida. Ribeirão Pires, São Paulo, Brasil, 2005.

\begin{tabular}{|c|c|c|c|c|c|c|}
\hline $\begin{array}{c}\text { Ciclo de } \\
\text { vida }\end{array}$ & Tamanho & $\mathrm{n}^{0}$ & $\begin{array}{c}\text { Casos } \\
\%\end{array}$ & $\begin{array}{c}\text { Controles } \\
\%\end{array}$ & $\begin{array}{c}\chi^{2} \\
\text { Pearson }\end{array}$ & $p$ \\
\hline $1^{\circ}$ ano & Nenhuma & 324 & 63,3 & 36,7 & \multirow{5}{*}{0,30} & \multirow{5}{*}{0,960} \\
\hline \multirow[t]{4}{*}{ de vida } & Pequena & 153 & 608 & 39,2 & & \\
\hline & Média & 2 & - & 100,0 & & \\
\hline & Grande & 3 & 66,7 & 33,3 & & \\
\hline & Total & 500 & 62,4 & 37,6 & & \\
\hline \multirow{5}{*}{$\begin{array}{l}1 \text { a } 3 \\
\text { anos }\end{array}$} & Nenhuma & 35 & 60,0 & 40,0 & \multirow{5}{*}{1,52} & \multirow{5}{*}{0,677} \\
\hline & Pequena & 348 & 61,8 & 38,2 & & \\
\hline & Média & 83 & 68,7 & 31,7 & & \\
\hline & Grande & 28 & 64,3 & 35,7 & & \\
\hline & Total & 494 & 63,0 & 37,0 & & \\
\hline 4 a 6 & Nenhuma & 8 & 25,0 & 75,0 & \multirow{5}{*}{7,36} & \multirow{5}{*}{0,061} \\
\hline \multirow[t]{4}{*}{ anos } & Pequena & 212 & 63,7 & 36,3 & & \\
\hline & Média & 179 & 66,5 & 33,5 & & \\
\hline & Grande & 83 & 56,6 & 43,4 & & \\
\hline & Total & 482 & 62,9 & 37,1 & & \\
\hline
\end{tabular}




\subsection{Idade de início do uso de dentifrício, escovações diárias e enxágües após a escovação}

As médias relativas à idade de início do uso de dentifrícios, ao número de escovações diárias e de enxágües após a escovação estão apresentadas na Tabela 32.

Tabela 32 - Medidas descritivas relativas às variáveis de exposição ao flúor em adolescentes casos e controles em área com água fluoretada. Ribeirão Pires, São Paulo, Brasil, 2005.

\begin{tabular}{|c|c|c|c|c|c|c|c|c|}
\hline Variáveis & $\mathrm{n}^{0}$ & $\bar{x}$ & d.p. & Q25 & Me & Q75 & $t^{\star}$ & $\mathrm{p}^{\star *}$ \\
\hline \multicolumn{9}{|l|}{$\begin{array}{l}\text { Idade de início do } \\
\text { uso de dentifrícios } \\
\text { (em meses) }\end{array}$} \\
\hline Casos & 305 & 17,88 & 12,67 & 12,00 & 12,00 & 24,00 & $-0,267$ & 0,647 \\
\hline Controles & 185 & 17,57 & 11,88 & 12,00 & 12,00 & 24,00 & & \\
\hline \multicolumn{9}{|l|}{ 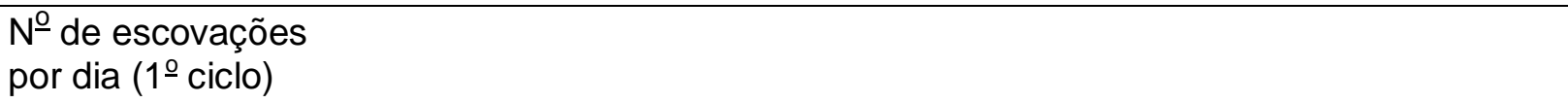 } \\
\hline Casos & 296 & 0,81 & 1,26 & - & - & 2,00 & $-0,600$ & 0,549 \\
\hline Controles & 174 & 0,74 & 1,13 & - & - & 2,00 & & \\
\hline \multicolumn{9}{|l|}{$\begin{array}{l}\text { № de escovações } \\
\text { por dia ( } 2^{\circ} \text { ciclo) }\end{array}$} \\
\hline Casos & 296 & 2,15 & 0,97 & 2,00 & 2,00 & 3,00 & 0,244 & 0,808 \\
\hline Controles & 174 & 2,17 & 1,11 & 2,00 & 2,00 & 3,00 & & \\
\hline \multicolumn{9}{|c|}{$\begin{array}{l}N^{0} \text { de escovações } \\
\text { por dia (3ำ ciclo) }\end{array}$} \\
\hline Casos & 296 & 2,64 & 0,84 & 2,00 & 3,00 & 3,00 & 0,740 & 0,883 \\
\hline Controles & 174 & 2,63 & 0,90 & 2,00 & 3,00 & 3,00 & & \\
\hline \multicolumn{9}{|l|}{$\begin{array}{l}\text { № de enxágües por } \\
\left.\text { escovação ( } 1^{\circ} \text { ciclo }\right)\end{array}$} \\
\hline Casos & 218 & 2,04 & 3,22 & - & - & 3,00 & $-0,919$ & 0,359 \\
\hline Controles & 139 & 2,38 & 3,53 & - & - & 8,00 & & \\
\hline \multicolumn{9}{|l|}{$\begin{array}{l}\text { № de enxágües por } \\
\text { escovaçãa ( } 2^{\circ} \text { ciclo) }\end{array}$} \\
\hline Casos & 218 & 4,39 & 3,04 & 2,00 & 3,00 & 8,00 & 0,877 & 0,381 \\
\hline Controles & 139 & 4,68 & 3,09 & 2,00 & 3,00 & 8,00 & & \\
\hline \multicolumn{9}{|l|}{$\begin{array}{l}\text { № de enxágües por } \\
\text { escovação ( } 3^{\circ} \text { ciclo) }\end{array}$} \\
\hline Casos & 218 & 4,27 & 2,62 & 2,00 & 3,00 & 8,00 & $-1,543$ & 0,124 \\
\hline Controles & 139 & 3,82 & 2,72 & 2,00 & 3,00 & 8,00 & & \\
\hline
\end{tabular}

\footnotetext{
* Valor do teste "t" de Student para amostras independentes.

** Probabilidade de rejeição da hipótese de nulidade.
} 
Nenhuma das sete variáveis apresentou diferença estatisticamente significativa entre casos e controles. Para a idade de início do uso de dentifrícios optou-se pela caracterização da exposição precoce ao dentifrício em cada ciclo e, para o número de escovações diárias o limite de risco por ciclo (Tabela 37 ). Em relação ao número de enxágües após a escovação não foram consideradas necessárias novas categorizações.

\subsection{Ingestão de dentifrícios}

Em relação à ingestão de dentifrícios houve menção de ingestão pelo responsável de um caso no primeiro ciclo e não se considerou necessária qualquer tipo de categorização.

\subsection{Produto com flúor e freqüência de utilização na pré- escola}

As distribuições de casos e controles segundo tipo de produto com flúor utilizado na pré-escola (Tabela 33) e freqüência de uso dos mesmos (Tabela 34) estão apresentadas a seguir.

Tabela 33 - Porcentagem de casos e controles segundo tipo de produto com flúor utilizado na pré-escola. Ribeirão Pires, São Paulo, Brasil, 2005.

\begin{tabular}{lrcc}
\hline \multicolumn{1}{c}{ Tipo de produto } & $\mathrm{n}^{\text {o }}$ & $\begin{array}{c}\text { Casos } \\
\%\end{array}$ & $\begin{array}{c}\text { Controles } \\
\%\end{array}$ \\
\hline Não freqüentou & 144 & 62,5 & 37,5 \\
Nenhum & 4 & 100,0 & - \\
Outro & 1 & 100,0 & - \\
Gel fluorado & 41 & 63,4 & 36,6 \\
Soluções de bochecho & 28 & 78,6 & 21,4 \\
Creme dental & 6 & 66,7 & 33,3 \\
Não identificado & 222 & 57,7 & 42,3 \\
\hline Total & 446 & 61,7 & 38,3 \\
\hline$\chi^{2}$ Pearson $=8,16 \mathrm{p}=0,227$ & &
\end{tabular}

Devido à dificuldade de identificação, pelos entrevistados, do tipo de produto utilizado nas ações desenvolvidas na pré-escola, observou-se a 
necessidade de serem criadas categorias de "não expostos" e de "expostos", independente do tipo de produto (Tabela 38 ).

Tabela 34 - Porcentagem de casos e controles segundo freqüência semanal de uso de produto na pré-escola. Ribeirão Pires, São Paulo, Brasil, 2005.

\begin{tabular}{lrcc}
\hline Freqüência semanal & $\mathrm{n}^{\circ}$ & $\begin{array}{c}\text { Casos } \\
\%\end{array}$ & $\begin{array}{c}\text { Controles } \\
\%\end{array}$ \\
\hline Não freqüentou & 140 & 63,6 & 36,4 \\
$<1$ vez & 97 & 62,9 & 37,1 \\
1 vez & 78 & 67,9 & 32,1 \\
$>1$ vez & 20 & 55,0 & 45,0 \\
\hline Total & 335 & 63,9 & 36,1 \\
\hline$\chi^{2}$ Pearson $=1,29 p=0,731$ & &
\end{tabular}

Da mesma forma que para o tipo de produto, houve a necessidade de criar categorias de "não exposição" (não freqüentou e menos de 1 vez por semana) e "exposição" (1 vez por semana ou mais) (Tabela 38).

\subsection{Variáveis sócio-econômicas}

Conforme descrito na apresentação da Tabela 11, observou-se, pelo número de categorias, a necessidade de combinação de algumas delas, no sentido de permitir uma análise das tendências observadas.

No caso da escolaridade dos pais, as sete categorias iniciais foram agrupadas em três: até primeiro grau incompleto; até segundo grau completo e até nível superior completo.

Ainda em relação à escolaridade, procurou-se avaliar se a interação entre a escolaridade do pai e a da mãe poderia levar à associação com a fluorose dentária. Foi criada uma variável com as seguintes categorias: pai e mãe até primeiro grau incompleto, pai com até primeiro grau incompleto e mãe com primeiro grau completo e mais; pai com primeiro grau completo e mais e mãe com até primeiro grau incompleto; e pai e mãe com primeiro grau completo e mais. 
Conforme destacado na apresentação da Tabela 12 e da Tabela 13, em relação à profissão dos pais, as 32 categorias iniciais da profissão pai e as 21 da profissão da mãe foram combinadas em três categorias, de acordo com o tipo de formação necessária para a atuação profissional. As distribuições de freqüências de casos e controles segundo essas categorizações estão apresentadas na Tabela 35.

Como todas as variáveis estiveram próximas de associação estatística significativa com a fluorose dentária, inclusive a interação entre escolaridade do pai e escolaridade da mãe, qualquer uma delas poderia ser eleita para análise de regressão logística múltipla não condicional. 
Tabela 35 - Porcentagem de casos e controles segundo variáveis sócioeconômicas. Ribeirão Pires, São Paulo, Brasil, 2005.

\begin{tabular}{|c|c|c|c|c|c|c|}
\hline Variável & Categorias & $\mathrm{n}^{0}$ & $\begin{array}{c}\text { Casos } \\
\%\end{array}$ & $\begin{array}{c}\text { Controles } \\
\%\end{array}$ & $\begin{array}{c}\chi^{2} \\
\text { Pearson } \\
\end{array}$ & $p$ \\
\hline \multirow{4}{*}{$\begin{array}{l}\text { Escola- } \\
\text { ridade } \\
\text { do pai }\end{array}$} & Sem $+1^{\circ}$ grau incompleto & 214 & 57,9 & 42,1 & \multirow{4}{*}{4,75} & \multirow{4}{*}{0,093} \\
\hline & $\begin{array}{l}1^{\circ} \text { grau completo }+2^{\circ} \text { grau } \\
\text { incompleto }+2^{\circ} \text { grau completo }\end{array}$ & 231 & 66,2 & 33,8 & & \\
\hline & $\begin{array}{l}\text { Superior incompleto + superior } \\
\text { completo }\end{array}$ & 30 & 73,3 & 26,7 & & \\
\hline & Total & 475 & 62,9 & 37,1 & & \\
\hline \multirow{4}{*}{$\begin{array}{l}\text { Escola- } \\
\text { ridade } \\
\text { da mãe }\end{array}$} & Sem $+1^{\circ}$ grau incompleto & 224 & 63,4 & 36,6 & \multirow{4}{*}{4,56} & \multirow{4}{*}{0,102} \\
\hline & $\begin{array}{l}1^{\circ} \text { grau completo }+2^{\circ} \text { grau } \\
\text { incompleto }+2^{\circ} \text { grau completo }\end{array}$ & 246 & 60,2 & 39,8 & & \\
\hline & $\begin{array}{l}\text { Superior incompleto + superior } \\
\text { completo }\end{array}$ & 30 & 80,0 & 20,0 & & \\
\hline & Total & 500 & 62,8 & 37,2 & & \\
\hline \multirow{4}{*}{$\begin{array}{l}\text { Ocupa- } \\
\text { ção } \\
\text { principal } \\
\text { do pai }\end{array}$} & Superior + técnico & 35 & 77,1 & 22,9 & \multirow{4}{*}{4,81} & \multirow{4}{*}{0,090} \\
\hline & Técnico & 200 & 64,5 & 35,5 & & \\
\hline & Outros & 188 & 58,5 & 41,5 & & \\
\hline & Total & 423 & 62,9 & 37,1 & & \\
\hline \multirow{4}{*}{$\begin{array}{l}\text { Ocupa- } \\
\text { ção } \\
\text { principal } \\
\text { da mãe }\end{array}$} & Superior + técnico & 30 & 80,0 & 20,0 & \multirow{4}{*}{4,84} & \multirow{4}{*}{0,089} \\
\hline & Técnico & 68 & 57,4 & 42,6 & & \\
\hline & Outros & 353 & 61,2 & 38,8 & & \\
\hline & Total & 451 & 61,9 & 38,1 & & \\
\hline \multirow{5}{*}{$\begin{array}{l}\text { Intera- } \\
\text { ção es- } \\
\text { colarida } \\
\text { de do } \\
\text { pai e da } \\
\text { mãe }\end{array}$} & $\begin{array}{l}\text { Pai e mãe }\left(\text { sem }+1^{\circ} \text { grau }\right. \\
\text { incompleto) }\end{array}$ & 139 & 58,3 & 41,7 & \multirow{5}{*}{6,53} & \multirow{5}{*}{0,089} \\
\hline & $\begin{array}{l}\text { Pai }\left(1^{\circ} \text { grau incompleto e }\right. \\
\text { menos }) \text { e mãe }\left(1^{\circ} \text { grau }\right. \\
\text { completo e mais })\end{array}$ & 72 & 56,9 & 43,1 & & \\
\hline & $\begin{array}{l}\text { Pai (1ํ grau completo e mais) } \\
\text { e mãe (1 grau incompleto e } \\
\text { menos) }\end{array}$ & 70 & 74,3 & 25,7 & & \\
\hline & $\begin{array}{l}\text { Pai e mãe ( } 1^{\circ} \text { grau completo e } \\
\text { mais) }\end{array}$ & 187 & 64,7 & 35,3 & & \\
\hline & Total & 468 & 63,0 & 37,0 & & \\
\hline
\end{tabular}




\subsection{Variáveis relacionadas à água}

Conforme descrito na apresentação da Tabela 15 e da Tabela 16, foi identificada a necessidade de se analisar a exposição à água encanada e de poço, assegurando-se a sua continuidade entre os ciclos. Para essa análise, foram criadas, para a água ingerida e para a água de preparo de alimentos; as categorias exposição à água de poço nos três ciclos, exposição à água encanada nos três ciclos e as demais combinações entre outros tipos de água e ciclos.

Em relação ao uso de filtro para água (Tabela 20), foi destacada a necessidade de avaliação da continuidade da exposição, pois houve semelhança na distribuição entre casos e controles no segundo e terceiro ciclos e uma situação diferente no primeiro ciclo. Foram criadas as categorias não ter usado filtro em nenhum ciclo, ter usado nos três ciclos e demais combinações de uso entre os ciclos.

A exposição à água encanada para ingestão, ao longo dos ciclos, não apresentou associação estatística significativa $\left(\chi^{2}=5,62 ; p=0,132\right)$ e não foi incluída no modelo de regressão logística múltipla não condicional.

A exposição contínua à água encanada no preparo de alimentos apresentou associação estatística com a ocorrência de fluorose dentária $\left(\chi^{2}=9,73 ; p=0,008\right)$, e foi eleita para a análise de regressão logística múltipla não condicional.

Em relação ao uso de filtro para água, embora os resultados apontem uma associação estaticamente significativa com a ocorrência de fluorose dentária ( $\left.\chi^{2}=5,78 ; p=0,056\right)$, essa não se deu com a exposição constante e sim com as diversas combinações de exposições entre os ciclos (categoria "demais"), o que não justificaria sua inclusão no modelo de regressão múltipla, pois dificultaria a interpretação da medida de associação. Esses resultados estão apresentados na Tabela 36. 
Tabela 36 - Porcentagem de casos e controles segundo variáveis relacionadas à água. Ribeirão Pires, São Paulo, Brasil, 2005.

\begin{tabular}{|c|c|c|c|c|c|c|}
\hline Variável & Categorias & $\mathrm{n}^{0}$ & $\begin{array}{c}\text { Casos } \\
\%\end{array}$ & $\begin{array}{c}\text { Controles } \\
\%\end{array}$ & $\begin{array}{c}\chi^{2} \\
\text { Pearson }\end{array}$ & $p$ \\
\hline \multirow{5}{*}{$\begin{array}{l}\text { Água para } \\
\text { ingestão }\end{array}$} & Poço (3 ciclos) & 32 & 43,8 & 56,3 & \multirow{5}{*}{5,56} & \multirow{5}{*}{0,132} \\
\hline & Demais & 89 & 61,8 & 38,2 & & \\
\hline & Encanada (3 ciclos) & 364 & 64,3 & 35,7 & & \\
\hline & Encanada ( $1^{\circ}$ e $2^{\circ}$ ciclos) & 22 & 68,2 & 31,8 & & \\
\hline & Total & 475 & 62,9 & 37,1 & & \\
\hline \multirow{4}{*}{$\begin{array}{l}\text { Água para } \\
\text { preparo de } \\
\text { alimentos }\end{array}$} & Poço (3 ciclos) & 36 & 38,9 & 61,1 & \multirow{4}{*}{9,73} & \multirow{4}{*}{0,008} \\
\hline & Demais & 48 & 60,4 & 39,6 & & \\
\hline & Encanada (3 ciclos) & 422 & 60,2 & 39,8 & & \\
\hline & Total & 506 & 62,8 & 37,2 & & \\
\hline \multirow{4}{*}{$\begin{array}{l}\text { Filtro para } \\
\text { água }\end{array}$} & Nunca & 91 & 53,8 & 46,2 & \multirow{4}{*}{5,78} & \multirow{4}{*}{0,056} \\
\hline & 3 ciclos & 321 & 62,9 & 37,1 & & \\
\hline & Demais & 90 & 71,1 & 28,9 & & \\
\hline & Total & 502 & 62,7 & 37,3 & & \\
\hline
\end{tabular}

\subsection{Variáveis relacionadas ao uso de dentifrícios}

Em relação ao tipo de dentifrício (Tabela 28) foi identificada a necessidade de caracterizar a exposição contínua ao dentifrício. Foram criadas as seguintes categorias: não usar ou usar dentifrício de forma irregular; usar dentifrício com flúor somente no primeiro ciclo; usar dentifrício com flúor no primeiro e segundo ciclos, e usar dentifrício com flúor nos três ciclos.

Para isso foram criadas as seguintes categorias: não usar associado a pai e mãe como responsáveis; criança como responsável no segundo ciclo; criança como responsável nos segundo e terceiro ciclos, e criança responsável no terceiro ciclo.

Para a quantidade de dentifrício dispensada na escova (Tabela 29) foram estabelecidas quantidades de risco para cada ciclo: $0,25 \mathrm{~g}$ ou mais para o primeiro ciclo, $0,5 \mathrm{~g}$ ou mais para o segundo ciclo e $0,75 \mathrm{~g}$ ou mais 
para o terceiro ciclo. Além disso, foram estabelecidas mais duas categorias: exposição a dose de risco em mais de um ciclo e em todos.

Em relação ao responsável pela colocação do dentifrício (Tabela 30), devido à associação estatisticamente significativa entre a criança como responsável pela colocação quando comparada com a categoria "não usava" e às freqüências baixas em algumas categorias; considerou-se adequado isolar a criança como responsável pela colocação do dentifrício no terceiro ciclo das demais categorias e avaliar a continuidade dessa exposição entre $o$ segundo e terceiro ciclo (em cada um deles ou em ambos).

No que diz respeito ao tamanho da cabeça da escova de dentes (Tabela 31), foram criadas as categorias pequena, média e grande para os três ciclos e as diversas combinações entre os ciclos.

Em relação à idade de início do uso de dentifrícios (Tabela 32) foi identificada a necessidade de caracterizar a exposição precoce ao dentifrício em cada ciclo. Foram criadas as seguintes categorias: exposição no período de 1 a 12 meses de idade, no período de 13 a 24 meses de idade e depois de 25 meses de idade.

Foi identificada a necessidade de se estabelecer um limite de risco no número de escovações diárias e sua continuidade pelos ciclos (Tabela 32). Foram criadas as seguintes categorias: não usar ou escovar menos de três vezes ao dia; escovar mais de três vezes ao dia no primeiro ciclo; escovar mais de três vezes ao dia no segundo ciclo, e escovar mais de três vezes ao dia no segundo ciclo.

Essas novas modalidades e as associações com a fluorose dentária estão apresentadas na Tabela 36. Das variáveis apresentadas foram selecionadas para o modelo de regressão logística o uso de dentifrício fluoretado $\left(\chi^{2}=5,03 ; p=0,170\right)$ e o responsável pela colocação do dentifrício $\left(\chi^{2}=12,22 ; p=0,002\right)$. 
Tabela 37 - Porcentagem de casos e controles segundo variáveis relacionadas ao consumo de dentifrícios. Ribeirão Pires, São Paulo, Brasil, 2005.

\begin{tabular}{|c|c|c|c|c|c|c|}
\hline Variável & Categorias & $\mathrm{n}^{0}$ & $\begin{array}{c}\text { Casos } \\
\%\end{array}$ & $\begin{array}{c}\text { Controles } \\
\%\end{array}$ & $\begin{array}{c}\chi^{2} \\
\text { Pearson }\end{array}$ & $p$ \\
\hline \multirow{5}{*}{$\begin{array}{l}\text { Uso de } \\
\text { dentifrí- } \\
\text { cio }\end{array}$} & Não usar + uso irregular & 43 & 46,5 & 53,5 & \multirow{5}{*}{5,03} & \multirow{5}{*}{0,170} \\
\hline & Com flúor (1 ciclo) & 61 & 63,9 & 36,1 & & \\
\hline & Com flúor (2 ciclos) & 276 & 63,8 & 36,2 & & \\
\hline & Com flúor (3 ciclos) & 122 & 63,9 & 36,1 & & \\
\hline & Total & 502 & 62,4 & 37,6 & & \\
\hline \multirow{4}{*}{$\begin{array}{l}\text { Início de } \\
\text { uso de } \\
\text { dentifrí- } \\
\text { cio }\end{array}$} & $>$ de 25 meses & 82 & 64,6 & 35,4 & \multirow{4}{*}{0,64} & \multirow{4}{*}{0,726} \\
\hline & 13 a 24 meses & 103 & 65,0 & 35,0 & & \\
\hline & 1 a 12 meses & 323 & 61,3 & 38,7 & & \\
\hline & Total & 400 & 62,6 & 37,4 & & \\
\hline \multirow{7}{*}{$\begin{array}{l}\text { Quanti- } \\
\text { da de } \\
\text { de risco }\end{array}$} & Não & 64 & 64,1 & 35,9 & \multirow{7}{*}{4,29} & \multirow{7}{*}{0,509} \\
\hline & $1^{\circ}$ ciclo $(0,25 \mathrm{~g} \mathrm{ou}+)$ & 9 & 88,9 & 11,1 & & \\
\hline & $2^{\circ}$ ciclo $(0,5 \mathrm{~g}$ ou +$)$ & 43 & 62,8 & 37,2 & & \\
\hline & $3^{\circ}$ ciclo $(0,75$ ou +$)$ & 77 & 67,5 & 32,5 & & \\
\hline & Mais de um ciclo & 234 & 59,8 & 40,2 & & \\
\hline & Todos & 72 & 62,5 & 37,5 & & \\
\hline & Total & 499 & 62,7 & 37,3 & & \\
\hline \multirow{5}{*}{$\begin{array}{l}\text { Número } \\
\text { de } \\
\text { escova- } \\
\text { ções }\end{array}$} & Não (3X dia ou -) & 139 & 65,5 & 34,5 & \multirow{5}{*}{0,97} & \multirow{5}{*}{0,809} \\
\hline & $+3 \times$ dia (1 ciclo) & 74 & 62,2 & 37,8 & & \\
\hline & $+3 \times$ dia (2 ciclos) & 88 & 59,1 & 40,9 & & \\
\hline & $+3 \times$ dia (3 ciclos) & 169 & 63,3 & 36,7 & & \\
\hline & Total & 470 & 63,0 & 37,0 & & \\
\hline \multirow{5}{*}{$\begin{array}{l}\text { Cabeça } \\
\text { da } \\
\text { escova }\end{array}$} & Pequena (3 ciclos) & 153 & 60,8 & 39,2 & \multirow{5}{*}{0,41} & \multirow{5}{*}{0,939} \\
\hline & Média (3 ciclos) & 18 & 61,1 & 38,9 & & \\
\hline & Grande (3 ciclos) & 5 & 60,0 & 40,0 & & \\
\hline & Demais & 333 & 63,7 & 36,3 & & \\
\hline & Total & 509 & 62,7 & 37,3 & & \\
\hline \multirow{4}{*}{$\begin{array}{l}\text { Respon- } \\
\text { sável } \\
\text { pela co- } \\
\text { locação }\end{array}$} & Pais + cuidador & 216 & 54,2 & 45,8 & \multirow{4}{*}{12,22} & \multirow{4}{*}{0,002} \\
\hline & Criança ( $2^{\circ}$ ciclo $/ 2^{\circ}$ e $3^{\circ}$ ciclos $)$ & 73 & 64,4 & 35,6 & & \\
\hline & Criança ( $3^{\circ}$ ciclo) & 213 & 70,4 & 29,6 & & \\
\hline & Total & 502 & 62,5 & 37,5 & & \\
\hline
\end{tabular}




\subsection{Variáveis relacionadas à exposição a flúor na pré-escola}

Em relação às distribuições apresentadas na Tabela 33 e Tabela 34, foi destacada a necessidade de criação, para as duas variáveis, das categorias "expostos" e "não expostos".

Para a variável produto foram criadas as categorias "não exposição" (não ter utilizado nenhum tipo de produto) e "exposição" (ter usado qualquer tipo de produto).

Para a variável freqüência foram criadas as seguintes categorias: "não exposição" (não freqüentou e menos de 1 vez por semana) e "exposição" (1 vez por semana ou mais).

Esses resultados estão apresentados na tabela 38.

Tabela 38 - Porcentagem de casos e controles segundo variáveis relacionadas à exposição a flúor na pré-escola. Ribeirão Pires, São Paulo, Brasil, 2005.

\begin{tabular}{|c|c|c|c|c|c|c|}
\hline Variável & Categorias & $\mathrm{n}^{\circ}$ & $\begin{array}{c}\text { Casos } \\
\% \\
\end{array}$ & $\begin{array}{c}\text { Controles } \\
\% \\
\end{array}$ & $\begin{array}{c}\chi^{2} \\
\text { Pearson }\end{array}$ & $p$ \\
\hline \multirow{3}{*}{$\begin{array}{l}\text { Exposi- } \\
\text { ção a } \\
\text { produto } \\
\text { c/ flúor }\end{array}$} & Não & 148 & 63,5 & 36,5 & \multirow{3}{*}{3,22} & \multirow{3}{*}{0,570} \\
\hline & Sim & 298 & 60,7 & 39,3 & & \\
\hline & Total & 446 & 61,7 & 38,3 & & \\
\hline \multirow{3}{*}{$\begin{array}{l}\text { Freqüên- } \\
\text { cia de } \\
\text { exposi- } \\
\text { ção }\end{array}$} & Não exposição & 237 & 63,3 & 36,7 & \multirow{3}{*}{0,122} & \multirow{3}{*}{0,727} \\
\hline & $\begin{array}{l}1 \text { vez por } \\
\text { semana ou }+\end{array}$ & 98 & 65,3 & 34,7 & & \\
\hline & Total & 335 & 63,9 & 36,1 & & \\
\hline
\end{tabular}

Nenhuma das variáveis relacionadas à exposição a flúor na préescola apresentou associação estatisticamente significativa com a ocorrência de fluorose dentária. Assim, não foram incluídas no modelo de regressão múltipla. 


\subsection{Análise univariada}

Após a descrição das variáveis e o exame da presença ou não de associação com os casos de fluorose dentária, algumas variáveis foram selecionadas para análise univariada. $O$ efeito de cada variável na chance de ocorrência de fluorose dentária está apresentado na Tabela 39.

Observa-se que a criança como responsável pela colocação do dentifrício no terceiro ciclo (de 4 a 6 anos de idade), apresentou duas vezes mais chance de associação com a presença de fluorose dentária quando comparada com a categoria de referência (OR=2,06; IC95\%=1,35-3,00; $p=0,001)$.

A utilização de água encanada para preparo de alimentos nos três ciclos (primeiro ano de vida até 6 anos de idade) apresentou três vezes mais chance de associação com a presença de fluorose dentária, quando comparada com a categoria de referência (OR=2,91; IC95\%=1,45-5,85; $p=0,003)$.

O uso de dentifrício fluoretado em dois ciclos e em três ciclos apresentou duas vezes mais chance de associação com a presença de fluorose dentária do que a não utilização ou a utilização em um ciclo $(\mathrm{OR}=2,02 ; \quad$ IC $95 \%=1,06-3,87 ; \quad \mathrm{p}=0,033 \quad$ e $\quad \mathrm{OR}=2,04 ; \quad \mathrm{IC} 95 \%=1,01-4,12$; $\mathrm{p}=0,047)$.

A interação entre escolaridade do pai e escolaridade da mãe, quando o pai tem acima do primeiro grau completo e a mãe com até primeiro grau incompleto, apresentou duas vezes mais a chance de associação com a presença de fluorose dentária, quando comparada com a categoria de referência $(O R=2,07 ; \mathrm{IC} 95 \%=1,10-3,90 ; p=0,024)$. 
Tabela 39 - Análise univariada da ocorrência de fluorose dentária em adolescentes residentes em área fluoretada segundo exposição a flúor e escolaridade dos pais. Ribeirão Pires, São Paulo, Brasil, 2005.

\begin{tabular}{rrlrr}
\hline Variáveis & no & \multicolumn{1}{c}{ OR [IC $95 \%]$} & $\chi^{2}$ Wald & $p$ \\
\hline Responsável pelo uso do dentifrício & & & & \\
não + pais + cuidador & 216 & 1,00 & & \\
criança (somente no $2^{\circ}$ ciclo $+2^{\circ}$ e $3^{\circ}$ ciclos) & 73 & $1,53[0,88-2,65]$ & 2,30 & 0,129 \\
criança (somente no $3^{\circ}$ ciclo) & 213 & $2,06[1,35-3,00]$ & 11,91 & 0,001
\end{tabular}

Água para preparo de alimentos

$\begin{array}{rrlrr}\text { poço (3 ciclos) } & 36 & 1,00 & & \\ \text { demais } & 48 & 2,40[1,00-5,81] & 3,75 & 0,053 \\ \text { encanada (3 ciclos) } & 422 & 2,91[1,45-5,85] & 8,96 & 0,003\end{array}$

Uso de dentifrício

$\begin{array}{rrlll}\text { nenhum + irregular } & 43 & 1,00 & & \\ \text { com flúor(1 ciclo) } & 61 & 2,04[0,92-4,52] & 3,08 & 0,079 \\ \text { com flúor (2 ciclos) } & 276 & 2,02[1,06-3,87] & 4,55 & 0,033 \\ \text { com flúor (3 ciclos) } & 122 & 2,04[1,01-4,22] & 3,93 & 0,047\end{array}$

Escolaridade do pai

$\begin{array}{rrlll}1^{\circ} \text { grau incompleto } & 214 & 1,00 & & \\ 2^{\circ} \text { grau completo } & 231 & 1,42[0,97-2,09] & 3,24 & 0,072 \\ \text { superior incompleto e mais } & 30 & 2,00[0,85-4,67] & 2,52 & 0,112\end{array}$

Escolaridade da mãe

$\begin{array}{rrlll}1^{\circ} \text { grau incompleto } & 227 & 1,00 & & \\ 2^{\circ} \text { grau completo } & 246 & 0,87[0,60-1,27] & 0,52 & 0,472 \\ \text { superior incompleto e mais } & 30 & 2,31[0,91-5,88] & 3,08 & 0,079\end{array}$

Escolaridade pai * escolaridade mãe

\begin{tabular}{rrrrr}
$1^{\circ}$ g. incomp. pai e mãe & 139 & 1,00 & & \\
$1^{\circ}$ g. incomp. pai e $1^{\circ}$ g. comp. e mais mãe & 72 & $0,95[0,53-1,68]$ & 0,03 & 0,853 \\
$1^{\circ}$ g. comp. e mais pai e $1^{\circ}$ g. incomp. e menos mãe & 70 & $2,07[1,10-3,90]$ & 5,06 & 0,024 \\
$1^{\circ}$ g. comp. e mais pai e mãe & 187 & $1,31[0,84-2,06]$ & 1,40 & 0,237 \\
\hline
\end{tabular}




\subsection{Modelo de regressão logística múltipla não condicional}

O modelo de regressão logística múltipla não condicional está apresentado na Tabela 40.

Incluiu as variáveis relacionadas à exposição ao flúor: responsável pela colocação do dentifrício, água para preparo de alimentos e uso de dentifrício e a variável sócio-econômica interação da escolaridade do pai e da escolaridade da mãe. Houve um ajuste na força da variável responsável pela colocação de dentifrício, um aumento da força de associação da variável água para preparo de alimentos e a variável uso de dentifrício passou a ter significância estatística. 
Tabela 40 - Fluorose dentária em adolescentes residentes em área fluoretada. Odds Ratio bruta, ajustada e intervalo de confiança (95\%), segundo exposição a flúor e escolaridade dos pais. Ribeirão Pires, São Paulo, Brasil, 2005.

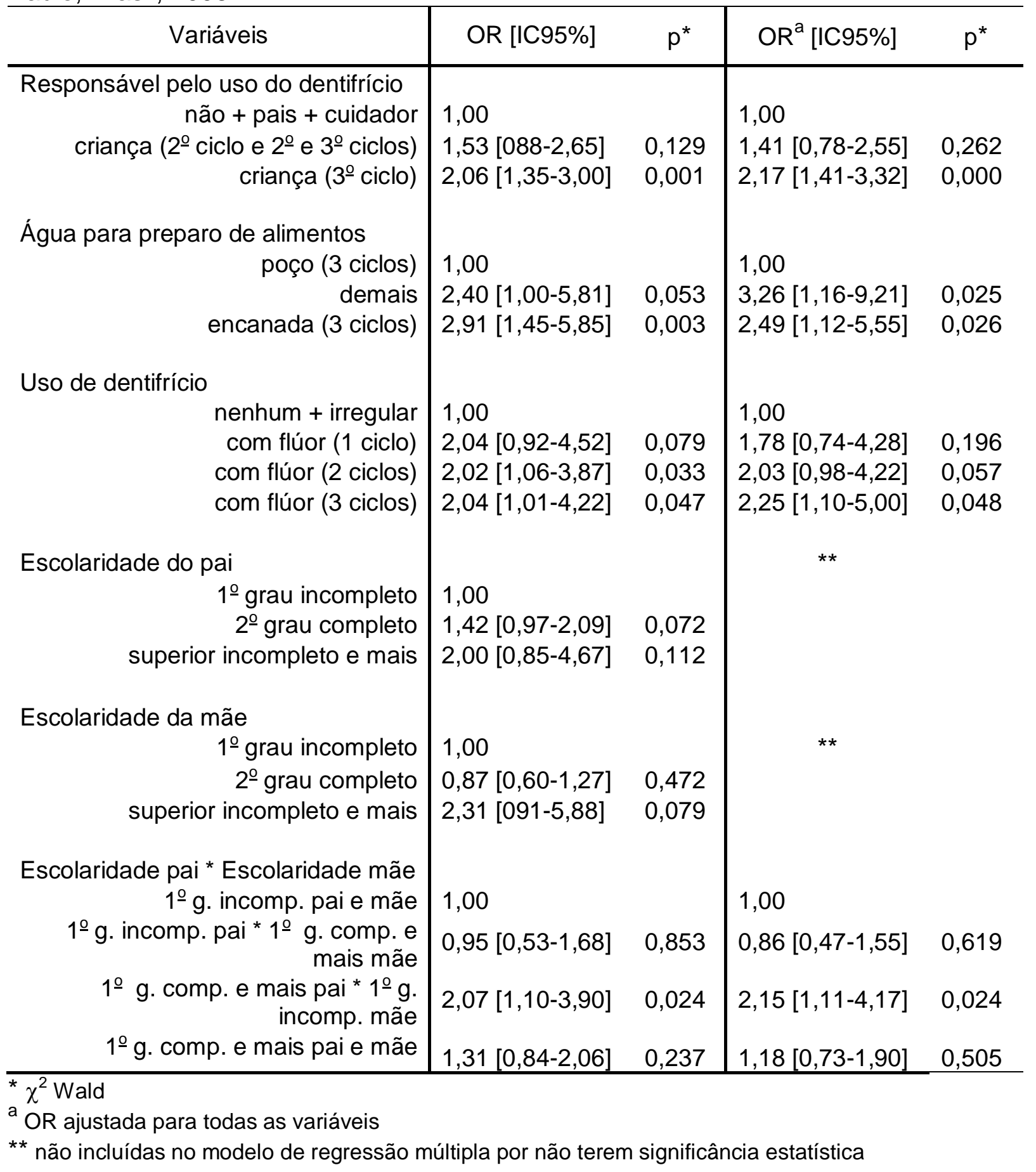




\section{DISCUSSÃO}

Este estudo, do tipo caso-controle buscou descrever a exposição ocorrida no passado de forma a estabelecer relação causal e investigar vários fatores simultaneamente (PEREIRA 1995).

Embora o estudo de caso-controle tenha algumas vantagens relativas à rapidez na obtenção de resultados, ao baixo custo, à possibilidade de investigação simultânea de vários fatores de risco e ao menor tamanho de amostra, quando comparado a outros estudos, ele apresenta algumas importantes fontes de viés (PEREIRA 1995; PENDRYS 1999; MASCARENHAS 2000). Para controlar tais aspectos, vários procedimentos técnicos foram adotados, entretanto algumas limitações podem ser ponderadas na análise dos resultados.

Com o objetivo de controlar o viés de aferição, isto é, os responsáveis por adolescentes considerados casos lembrarem-se com mais propriedade de certas exposições (PEREIRA 1995); o presente estudo teve a característica de duplo cego (familiares e entrevistadores desconheciam a condição de caso ou controle do adolescente de referência), buscando garantir a acurácia da comparabilidade, pois a medida da exposição para casos e controles foi realizada de forma semelhante.

Todavia é difícil assegurar que o domínio e o grau de conhecimento sobre o problema tenha sido semelhante entre todos os respondentes. Parte dos familiares mostraram conhecimento da presença do agravo, visto que, 49,9\% dos pais/responsáveis por casos declarou alguma alteração nos dentes de seus filhos. Por outro lado, não se sabe se conheciam a causa da alteração. $O$ fato de $O$ adolescente ter sido examinado na escola, onde foi atribuído um código (a examinadora ditava para a anotadora), associado ao convite aos pais/responsáveis para participar da pesquisa, cujo termo de consentimento destacava as alterações nos dentes, permitiria que se levantasse a hipótese do conhecimento do agravo. Com base nos procedimentos de controle das entrevistas, considera-se que isso não interferiu de modo importante na coleta dos dados. 
Em relação ao instrumento de coleta de dados, se por um lado a sua extensão (154 itens distribuídos em 24 páginas), oferecia um estímulo recordatório, por outro dificultava testes de reprodutibilidade e validade (PEREIRA 1995). Na presente pesquisa optou-se pela não realização destes testes, utilizando-se um formulário, que foi construído com a participação de parte dos entrevistadores. Este permitiu que as entrevistas se desenvolvessem a partir de uma relação fixa de perguntas, ordenadas de forma a facilitar ao entrevistado o menor esforço mental possível.

A entrevista foi motivada, nesse caso, pela atuação dos entrevistadores que participaram da construção do mesmo ou do treinamento para sua utilização. Essa característica da técnica da pesquisa exploratória foi importante na adequação da linguagem e facilitou o controle da subjetividade nas perguntas. $\mathrm{O}$ envolvimento dos profissionais de saúde do município teve a função de capacitação dos mesmos em relação a conteúdos sobre fluorose dentária, dirimindo tabus e ampliando a sua capacidade no papel de educadores em saúde.

Alguns itens de medida necessitam ser aprimorados ou mais reforçados no treinamento dos entrevistadores, de forma a reduzir respostas do tipo "não identificada" ou sem "informação". Como o instrumento era longo as entrevistas foram demoradas (em média 140 minutos), alguns fatores podem ter comprometido a coleta, como por exemplo o cansaço do entrevistador, a paralisação da atividade rotineira do entrevistado, bem como condições psicológicas e emocionais de ambos.

Outro viés a ser considerado é o de memória, destacado por PEREIRA (1995) e PENDRYS (1999). Torna-se bastante complexo controlálo, pois fatores psicológicos, sócio-culturais e até mesmo emocionais podem interferir nas respostas dos entrevistados.

Além da seqüência de organização das perguntas, e do uso de recursos visuais (fotos, esquemas, listas com nomes de produtos), não foram aplicados outros mecanismos para controlar o viés de memória. Para a maioria das variáveis o objetivo foi alcançado, excetuando-se alguns itens 
como duração do aleitamento materno ( 6 e 12 meses) e número de escovações diárias ( 3 vezes ao dia) nos quais houve concentração de respostas em determinada categoria.

A validade de dados recordados no passado garantida por um período pregresso de até 10 (dez) anos (WILLET 1998), foi parcialmente assegurada pois, como os adolescentes identificados tinham entre 12 e 15 anos de idade e os dados coletados eram relativos aos primeiros 6 (seis) anos de vida não foi possível cobrir os primeiros anos de vida dos adolescentes mais velhos.

Outro viés importante nesse tipo de estudo é o de seleção. A identificação de casos e controles pode ser considerada uma das maiores dificuldades desse tipo de estudo, podendo levar a importantes limitações em termos de comparabilidade.

A partir da relação de 667 adolescentes com fluorose dentária e 416 com esmalte normal, foi possível entrevistar 509 famílias (319 casos e 190 controles). A semelhança nas proporções de perdas (48\% dos casos e $46 \%$ dos controles) não prejudicou a comparabilidade dos grupos. O poder do estudo foi assegurado pelo tamanho da amostra. $O$ fato de ser caso ou controle não levou a diferenças na proporção de respostas positivas ou negativas, refletindo apenas as proporções de casos e controles encontradas na população estudada.

Quando estudos passados de fluorose dentária são comparados observa-se que o tamanho das amostras de casos e controles varia. OSUJI et al. (1988) identificaram 82 casos e 95 controles; PENDRYS e MORSE (1990) com 52 casos e 22 controles; PENDRYS et al. (1994) com 307 casos e 280 controles; PENDRYS e KATZ (1998) com 244 casos e 107 controles e VILLA et al. (1998) com 51 casos e 85 controles. Analisando-se esses estudos, pode-se notar que a amostra da presente pesquisa foi maior.

Em relação à seleção de casos, em estudos descritos na literatura (PENDRYS et al. 1994; SKOTOWSKI et al. 1995; PENDRYS e KATZ 1998), estes foram identificados entre os escolares com formas leves e moderadas de fluorose dentária. 
Para este estudo optou-se pela exclusão da categoria fluorose questionável para a condição presença de fluorose dentária, aplicada em estudos descritos na literatura onde foi utilizado o Índice de Dean (DEAN e McKAY 1939; GALAGAN e LAMSON 1953; WARNAKULASURIYA et al. 1992) e recomendada por HOROWITZ (1995).

Esta categoria também não aparece em outros sistemas de classificação da fluorose dentária como é o caso do TF (THYLSTRUP e FEJERSKOV 1978) e TSIF (HOROWITZ et al. 1984). Além disso, alguns autores destacaram as dificuldades de sua utilização (DEAN 1934; GRANATH et al. 1985; FEJERSKOV et al. 1994; Ekstrand et al. (1988), citados por PEREIRA (1996, p. 40).

No caso dos controles, como a seleção inadequada poderia comprometer o estudo, muita atenção foi dada no sentido de serem respeitadas, sempre que possível em um primeiro nível; as proporções dos casos por idade e sexo em cada escola e em um segundo nível, as proporções dentro de cada uma das oito regiões de residência. Além disso, a exclusão da categoria "questionável" do Índice de Dean (limítrofe entre casos e controles) e o controle da qualidade do cadastro foram outros cuidados observados com essa finalidade.

A utilização dos critérios do Índice de Dean facilitou tanto a identificação dos casos e controles, quanto a análise conjunta do efeito continuado de certos fatores de exposição. Para estudar os fatores implicados na ocorrência de fluorose dentária, PENDRYS (1990) propôs um índice chamado Fluorosis Risk Index (FRI); que classifica casos conforme o período de exposição aos fatores de risco mediante a distinção de zonas do esmalte que se formaram do nascimento ao primeiro anos de vida (classificação I) e entre o segundo e o sexto ano de vida (classificação II).

O FRI permite estabelecer com mais precisão o período de exposição ao flúor, e por conseguinte, o fator mais importante relacionado ao problema. Porém não assegura a análise conjunta de múltiplos fatores atuando em diferentes períodos e $\mathrm{m}$ um processo continuado de exposição. No presente 
estudo, esta continuidade de exposição foi determinada pela coleta de dados relativos aos fatores em diferentes ciclos de vida e suas combinações na categorização das variáveis.

Um último viés a ser destacado é o de processamento da informação (PEREIRA 1995), que pode levar a deturpação nos resultados por erros de codificação, transcrição, digitação ou programação no processamento dos dados.

Como o formulário continha perguntas abertas e fechadas, muitas vezes seqüencialmente complementares, a codificação das variáveis foi feita após análise do grupo de respostas de uma amostra contendo formulários preenchidos pelos vários entrevistadores. A transcrição foi feita por uma única pessoa (no caso a pesquisadora), de forma a ter o mesmo critério de interpretação e estabelecer coerência entre as respostas correspondentes a cada ciclo. Pelo grande número de perguntas esse processo não foi realizado em um único momento.

Os erros de transcrição e digitação puderam ser controlados por meio da digitação de dois bancos de dados e sua validação.

Identificados os possíveis vieses e as medidas para controlá-los, admite-se que os dados colhidos e analisados na presente pesquisa são válidos e confiáveis. O exame da literatura mostra que as formas de mensuração de certos eventos variaram nos diversos estudos (PENDRYS 1999); dificultando comparações entre os resultados (MASCARENHAS 2000). Esses aspectos e a plausibilidade científica foram considerados na análise e discussão dos resultados.

Por essas razões, alguns dados coletados foram desprezados pois tiveram uma proporção significativa de respostas sem informação ou de freqüências nulas, ou ainda apontaram problemas com a categorização das respostas.

A discussão dos resultados está estruturada nos seguintes tópicos: percepção do comprometimento estético; aleitamento materno no primeiro ano de vida; recipiente para preparo de alimentos; hábitos alimentares (leite 
associado a fórmulas e complementos, chá, sucos, e bebidas); medicamentos e seus prescritores; uso de produtos para bochechos domésticos; fatores relacionados à exposição a flúor na pré-escola. Esta seção é encerrada com a discussão dos resultados relativos à influência fatores sócio-econômicos, dos fatores relacionados à água e ao uso de dentifrícios na ocorrência da fluorose dentária.

\subsection{Percepção do comprometimento estético}

O presente estudo não teve como um dos objetivos identificar a percepção do comprometimento estético e, portanto, não foi selecionada uma amostra específica para essa variável. A preocupação com 0 comprometimento e a identificação da cor da alteração, teve apenas finalidade de identificar se a alteração era percebida e sua conseqüência em termos de necessidade de tratamento.

O comprometimento estético por manchas brancas (que aparecem em casos de fluorose muito leve e leve) foi identificado por 49,9\% dos entrevistados responsáveis por casos de fluorose dentária (Tabela 10). A proporção de adolescentes com fluorose muito leve e leve foi 88,4\% (Tabela 8) e $38,2 \%$ dos responsáveis por casos não identificaram problema (Tabela 10). Isso pode ser explicado pelo fato de em torno de um quarto dos dentes afetados serem posteriores (Tabela 9).

O estudo de CLARK e BERKOWITZ (1997), embora tenha identificado $40 \%$ de casos de fluorose que atingiram os incisivos superiores, teve uma prevalência de comprometimento estético de $1 \%$ a $4 \%$, dependendo de quem foi o responsável pela definição (examinador, participante ou responsável).

MOYSÉS et al. (2000) identificaram $88 \%$ de casos de fluorose muito leve e leve, porém, não encontraram associação estatistica entre a presença de fluorose dentária e o incômodo com a cor dos dentes (83\% do total de respondentes que apresentaram algum grau de fluorose dentária não se incomodavam com a cor dos seus dentes). 
MENEZES et al. (2002) encontraram uma proporção de 36,9\% de casos de fluorose muito leve e leve, sendo que desses, 22,8\% declararam não estar satisfeitos com seus dentes, porém as causas da insatisfação não estavam relacionadas em especial a manchas provocadas pela fluorose dentária.

$\mathrm{Na}$ presente pesquisa, embora tenha sido orientado aos entrevistadores o cuidado para não induzir os entrevistados, o fato de se ter identificado o adolescente na escola, ter sido agendada uma entrevista com os pais/responsáveis e ter a possibilidade de algum tipo de tratamento, pode ter influenciado em algum grau as respostas.

Além disso, a preocupação com a fluorose dentária tem sido incorporada na rotina dos serviços de saúde do município desde o primeiro estudo de caráter exploratório realizado em 1.997 (USP-FSP 2000).

\subsection{Aleitamento materno no primeiro ano de vida}

EKSTRAND et al. (1984) e OPINYA et al. (1991) observaram que não havia correlação entre o teor de flúor ingerido pela mãe e o teor de flúor no leite materno. Isso significa que o aleitamento materno exclusivo pode ser fator de proteção em relação ao desenvolvimento de fluorose dentária, nos dentes que têm seu esmalte se formando durante essa fase.

Esse efeito foi identificado por VILLA et al. (1998) em crianças que sempre viveram em local com 0,93 ppm de flúor na água de abastecimento (OR=0,86; IC $=0,75-0,98)$.

Um efeito significativo independente foi observado por BROTHWELL e LIMEBACK (1999) em crianças que viveram em uma área não fluoretada há quatro anos ou mais, porém não apontam se foi aleitamento materno exclusivo.

No caso da presente pesquisa, pelo fato de algumas informações ficarem comprometidas pelo grande número de respostas "sem informação", como idade de início do consumo de chás, sucos e outras bebidas, não foi 
possível identificar o período de aleitamento materno exclusivo dos adolescentes.

A necessidade de inclusão dessas perguntas foi identificada pela autora na pesquisa exploratória para a construção do formulário de entrevista, pois, inicialmente uma das tentativas foi identificar o período de aleitamento materno exclusivo. Os entrevistados indicavam um período, mas ao responder sobre o início do consumo principalmente de chás, apontavam uma idade contemplada no período de aleitamento citado anteriormente.

Feitas essas considerações, quando se analisou o aleitamento materno nas categorias "não", "de 1 a 6 meses" e de "7 a 12 meses", não foi observada associação estatística com a presença de fluorose dentária $\left(\chi^{2}=3,78 ; p=0,151\right)$.

\subsection{Recipiente para preparo de alimentos}

Não foram encontrados, na literatura científica consultada, estudos que buscaram identificar associação entre o tipo de recipiente utilizado para preparo de alimentos e a ocorrência de fluorose dentária.

A evaporação que ocorre no cozimento é uma fonte potencial da maior concentração de flúor nos alimentos e depende do material do recipiente e do tempo de ebulição (FULL e PARKINS 1975). Verificou-se que o efeito foi predominante no recipiente anti-aderente, sendo que, o de alumínio, quando comparado com os de aço inox e vidro refratário, aparentou remover o flúor, formando fluoreto de alumínio.

A liberação do alumínio de utensílios é aumentada na presença do flúor e vai depender do $\mathrm{pH}$ do produto formado durante o cozimento (TENNAKOKKE e WICKRAMANAYAKE 1987). Por outro lado, RIBEIRO (1992) não encontrou diferenças na concentração de flúor na água fervida em recipientes de alumínio delgado, alumínio espesso e aço inox. Apenas observou que a concentração de flúor vai aumentando com a evaporação, independente do recipiente. 
No presente estudo, não foi observada associação estatisticamente significativa entre o tipo de recipiente utilizado e a ocorrência de fluorose dentária. Todavia, a freqüência da categoria "recipiente de alumínio" se destacou entre as demais, sendo necessários estudos mais direcionados a esse fator, para se ter uma conclusão sobre a existência de associação.

\subsection{Hábitos alimentares}

\subsubsection{Leite associado a fórmulas e complementos}

As concentrações de flúor em leites concentrados americanos, na forma líquida e em pó, foram respectivamente de 0,12 ppm e 0,17 ppm. Já nas fórmulas à base de soja essa concentração, tanto na forma líquida quanto em pó concentrados, foi de 0,24 ppm (WINKLE et al. 1995). Não foram identificados, na literatura consultada, trabalhos que tivessem avaliado esses teores em produtos comercializados no Brasil. Além disso, a caracterização de fórmula infantil e complemento é complexa.

Para este estudo considerou-se fórmula infantil, apenas as formulações à base de soja (Anexo 4). Os demais produtos adicionados ao leite foram considerados complementos. O consumo de leite com fórmulas infantis não apresentou associação estatisticamente significativa em nenhum dos ciclos de vida (Tabela 17), achado semelhante ao estudo de BARDSEN et al. (1999), o qual não indicou o período de exposição, nem o que foi considerado fórmula infantil.

Também sem identificar período de exposição nem caracterizar fórmula infantil OSUJI et al. (1989) encontraram associação estatisticamente significativa do consumo de fórmulas com a presença de fluorose dentária $(\mathrm{OR}=3,53 ; \mathrm{IC}=1,44-8,65)$.

OSUJl et al. (1988) também observaram associação estatisticamente significativa do uso prolongado de fórmulas infantis com a fluorose dentária (OR=7,1; IC=1,14-44,5), e BARDSEN et al. (1999) encontraram associação com o uso por mais de uma vez ao dia $(p<0,05)$. Informações semelhantes não foram coletadas na presente pesquisa. 
Embora não tenha sido observada qualquer associação, não se pode desconsiderar, em futuros estudos, aspectos relativos à implicação do teor de flúor na água de preparo e a sua freqüência de uso para o peso da criança na época de consumo (WINKLE et al. 1995).

\subsubsection{Chá}

No presente estudo, foi considerado "chá verde" a utilização de qualquer tipo de folha para o preparo, "infusão" a utilização de sachês e "chá preto", a utilização tanto em sachês quanto em folha. Não foi observada diferença estatisticamente significativa entre os diferentes tipos de chás em nenhum dos três ciclos, e a ocorrência de fluorose dentária.

Esse resultado foi semelhante ao de GONINI (1999) que, embora tenha encontrado $96 \%$ da composição de sua amostra com o consumo de chás ou infusões de ervas, também não observou diferença estatisticamente significativa entre o consumo de chás no primeiro ano de vida e a ocorrência de fluorose dentária.

As freqüências de consumo de chá preto nos três ciclos foi muito baixa (3 adolescentes no primeiro ciclo, 6 no segundo ciclo e 8 no terceiro ciclo). Entre as bebidas consumidas por brasileiros, HEINTZE e BASTOS (1996) identificaram que apenas um tipo de água e o chá preto apresentou concentrações de flúor em torno de 1 ppm.

A baixa freqüência de consumo de chá preto observada na população do estudo corroborou o comportamento cultural destacado por CURY (1891) em relação aos hábitos alimentares no Brasil. Para que se chegue a conclusões concretas, estudos direcionados especificamente a essa variável necessitam ser conduzidos, principalmente quando se considera as diferenças de concentrações de flúor entre os chás preto e verde apontadas por SANTORO (1997) e os teores elevados de flúor em chás pretos comercializados no Brasil observados por BUZALAF et al. (2002) e HAYACIBARA et al. (2004) e o risco para fluorose dentária no caso de ingestão freqüente. 


\subsubsection{Sucos e bebidas}

Em relação ao consumo de sucos, o presente estudo buscou identificar se havia associação entre fluorose dentária e o consumo de sucos naturais ou sucos preparados com água. Essa informação foi coletada para o primeiro e o segundo ciclo. No terceiro ciclo, os sucos foram incorporados nas bebidas.

Foi observada maior freqüência de não consumo de sucos no primeiro ciclo e de consumo de sucos com água no segundo ciclo, porém essas diferenças não tiveram significância estatística na associação com a fluorose dentária.

Nos últimos anos, estudos medindo os teores de flúor em sucos e destacando o "efeito halo" em comunidades com e sem água fluoretada têm sido publicados (LOYOLA-RODRIGUEZ et al 1998; TURNER et. al. 1998). Embora os resultados desta pesquisa não tenham identificado associação entre o consumo de sucos preparados com água e a ocorrência do problema, esses aspectos merecem maiores investigações no Brasil.

Cabe destacar que não foi identificado se o tipo de bebida era ou não carbonatada. Os teores de flúor observados em bebidas carbonatadas nos Estados Unidos foram de 0,78 ppm (TURNER et al. 1998) e 0,72 ppm (HELIER et al. 1999). Apesar de não ter sido feita a identificação do tipo de bebida, cabe ressaltar o elevado consumo nos dois ciclos (em torno de $70 \%$ no segundo ciclo e de $86 \%$ no terceiro ciclo), valores acima dos $60 \%$ calculados por HEILMAN et al. (1999) com base no estudo de PANG (1992).

\subsubsection{Peixes}

Em relação ao consumo de peixes de água doce e de água salgada no segundo e terceiro ciclos, as distribuições de casos e controles apresentaram semelhanças.

Apenas dois estudos na literatura consultada buscaram estabelecer relações entre fluorose dentária e consumo de peixes. GIKUNJU (1992) não 
obteve relação entre o flúor acumulado em tilápias (peixe de água doce) e o quadro severo de fluorose dentária no Kênia. MALDE et al. (1997) avaliaram a concentração de flúor em alimentos selecionados de cinco áreas próximas de forma a explicar a fluorose endêmica de uma região africana e não obtiveram relação, recomendando novos estudos.

Embora na presente pesquisa não tenha sido observada associação entre o consumo de peixes e a fluorose dentária, pode-se notar maior freqüência de consumo de peixes, principalmente de água salgada (Tabela 23) entre os casos, porém sem diferenças estatisticamente significativas, com distribuição semelhante do consumo nos segundo e terceiro ciclos.

Como a literatura encontrada com relação à concentração de flúor em peixes é vaga e relativamente antiga, estudos com populações que têm o hábito de consumir peixes diariamente necessitam ser realizados para produzir conhecimentos sobre essas relações.

\subsection{Medicamentos e seus prescritores}

Nesse estudo 47 produtos comerciais (Anexo 3) foram considerados medicamentos com flúor.

$\mathrm{Na}$ literatura consultada aparecem duas formas de citação para os medicamentos: tabletes (de LIEDFE e HERBISON 1984; PENDRYS e MORSE 1990) e suplementos (BAGRAMIAN et al. 1989; NEWBRUN 1992; ISMAIL 1994; RIORDAN 1999; ISMAIL e BANDEKAR 1999; GONINI 1999; RIORDAN 1993; WANG 1997; LEVY e GUHA-CHOWDHURY 1999; PENDRYS e KATZ 1998 e PENDRYS et al. 1996).

Foram coletadas informações sobre o consumo de medicamentos na gestação e nos três ciclos de vida. Na gestação, não foi observada diferença estatisticamente significativa entre a utilização e a ocorrência de fluorose dentária.

Em cada ciclo não foram observadas diferenças significativas entre casos e controles e, ao se construir a exposição contínua, não houve 
freqüência suficiente para análise. Isso pode indicar que essa prática não é comum na população estudada.

Esses resultados diferiram dos valores encontrados em estudos realizados tanto em locais com água fluoretada (PENDRYS e MORSE 1990; PENDRYS e KATZ 1998), como em locais sem flúor na água ou com baixos teores (de LIEDFE e HERBISON 1984; PENDRYS et al. 1996; WANG et al. 1997; ISMAIL e BANDEKAR 1999).

Em relação à indicação de medicamentos o maior responsável pela prescrição foram os médicos (Tabela 26), nos três ciclos, porém nesses dados estão embutidos todos os tipos de medicamentos. A declaração de utilização de medicamentos com flúor foi inexpressiva na população estudada.

\subsection{Uso de produtos para bochechos domésticos}

Em relação a bochechos domésticos com soluções fluoretadas, não foi possível identificar qualquer associação devido à baixa freqüência (Tabela 27) de pais/responsáveis mencionando exposição dos filhos a esses produtos (4 no primeiro ciclo, 3 no segundo ciclo e 15 no terceiro ciclo).

Não se encontrou, na literatura pesquisada, estudos que tratassem desse aspecto, o que não tira a necessidade de uma abordagem específica; no sentido de se conhecer o uso real desses produtos, sua freqüência e faixas etárias de utilização, pois a auto-aplicação de produtos fluoretados pode estar associada à fluorose dentária (SZPUNAR e BURT 1988; STOOKEY 1994)

\subsection{Fatores relacionados à exposição a flúor na pré-escola}

O fato de os dados sobre exposição a flúor na pré-escola terem sido obtidos junto aos pais/responsáveis, pode justificar a dificuldade da identificação do tipo de produto utilizado. 
Dos pais/responsáveis pelos 302 adolescentes que freqüentaram a pré-escola, $222(73,5 \%)$ não conseguiram identificar o tipo de produto utilizado (Tabela 33). Quando todos os produtos foram combinados, não foi observada associação estatística significativa com a ocorrência de fluorose dentária (Tabela 38).

Em relação à freqüência de utilização, a proporção de informações de utilização de produtos, independente de serem casos ou controles, por mais de uma vez por semana (que poderia indicar uma tendência ao risco de fluorose dentária) alcançou cerca de 30\%, não havendo diferença estatisticamente significativa (Tabela 38).

$\mathrm{Na}$ literatura, WEI e KANELLIS (1983) compararam com controles crianças que se submeteram a um programa semanal de bochechos fluoretados. Embora tenham reconhecido algumas limitações no estudo, perceberam que crianças menores de 3 anos de idade ingeriam em maior proporção o total da solução de bochechos, quando comparadas com crianças de 4 e 5 anos de idade.

No município de Ribeirão Pires - SP, as ações desenvolvidas na préescola são as de escovação supervisionada e aplicação de gel fluoretado em crianças de alto risco de cárie dentária, mas essa é uma prática mais recente. No período em que os adolescentes envolvidos na pesquisa poderiam estar na pré-escola eram realizados procedimentos coletivos com aplicação de produtos fluoretados. A hipótese de risco pode ser considerada se a concentração e a freqüência de exposição a esses produtos fossem elevadas $e$ os procedimentos tenham sido realizados sem controle e supervisão.

\subsection{Fatores sócio-econômicos}

No presente estudo, as variáveis sócio-econômicas analisadas foram nível de escolaridade e profissão dos pais, as quais, de forma isolada ou combinada, podem estar associadas à renda familiar. 
No presente estudo, foram encontradas proporções de pais e de mães (94\%) com até o segundo grau completo diferentes da relatada por LEVY et al. (1997) de dois terços de pais e mães.

As proporções de $73 \%$ de pais e $71 \%$ de mães com até o segundo grau incompleto estão mais próximas das encontrados por MALTZ e SILVA (2001) que observaram, cerca da metade da amostra com nível de escolaridade até o segundo grau incompleto.

Quando se observam os valores resultantes do procedimento de categorização das variáveis escolaridade do pai, escolaridade da mãe e a interação entre elas (Tabela 39), nota-se que as modalidades que apresentaram associação com fluorose dentária próximas da significância estatística foram: de $1^{\circ}$ grau completo até $2^{\circ}$ grau completo para a escolaridade do pai $(O R=1,42 ; p=0,072)$ e de superior incompleto a superior completo para a escolaridade da mãe $(O R=2,31 ; p=0,079)$. Ao se analisar a interação entre escolaridade do pai e escolaridade da mãe (Tabela 39), notase que a associação estatística significativa ( $O R=2,07 ; p=0,024)$ se deu entre pai com $1^{\circ}$ grau completo e mais e mãe com $1^{\circ}$ grau incompleto e menos.

Nesse caso, a maior escolaridade do pai pode implicar em maior renda e traduzir o determinante sócio-econômico do agravo. Nessa lógica, maior risco de fluorose dentária pode ser explicado pela facilidade econômica de acesso a produtos fluoretados para prevenção da cárie dentária; a qual gera maior disponibilidade de tais produtos em nível domiciliar e pode resultar em uso forma mais freqüente e maior exposição quando comparado com adolescentes de famílias cuja escolaridade do pai é baixa.

Nível de escolaridade mais elevado, poderia levar a um conhecimento maior sobre doenças, como a cárie dentária e práticas preventivas com uso de flúor (GONINI 1999), porém pode significar também uso mais racional de tais produtos Por outro lado, a influência do menor nível de escolaridade da 
mãe poderia se refletir no determinante comportamental, com menores cuidados na supervisão da utilização desses produtos.

É lícito admitir que menor nível de escolaridade da mãe pode refletir determinantes ligados ao comportamento, implicando em deficiências na supervisão e na utilização desses produtos.

Assim, o aspecto mais importante que emerge dos resultados deste estudo, é o risco que a combinação alta escolaridade do pai e baixa escolaridade da mãe pode significar para o uso excessivo e irracional de tais produtos em nível domiciliar.

Embora MELLA et al. (1994) não tenham citado como caracterizaram nível sócio-econômico médio alto, e admitindo correlação positiva entre nível sócio-econômico e escolaridade dos pais (MALTZ e SILVA 2001), os resultados da presente pesquisa podem ser considerados, diferentes dos encontrados no estudo realizado no Chile (maior proporção de crianças do nível sócio-econômico médio-alto sem fluorose dentária).

A associação da escolaridade do pai com a ocorrência de fluorose dentária $(O R=2,2)$ e com o uso de suplementos fluoretados $(O R=2,7)$ foi observada por BRAGAMIAN et al. (1989). Na presente pesquisa, os resultados mostraram baixa exposição da população de estudo a suplementos fuoretados e não foi possível essa análise.

\subsection{Fatores relacionados à água}

A associação da ocorrência de formas leves de fluorose dentária com a água fluoretada foi destacada por BAWDEN (1996) e essa associação foi observada em diversos estudos realizados em regiões naturalmente fluoretadas dos Estados Unidos por $\mathrm{H}$. Tendley Dean e seus colaboradores (DEAN 1933; DEAN 1934; DEAN et al. 1935; DEAN e ELVOLVE 1935; DEAN e ELVOLVE 1936; DEAN 1936; DEAN e ELVOLVE 1937; DEAN et al. 1938; DEAN et al. 1939; DEAN e McKAY 1939; DEAN 1942; DEAN 1943; e DEAN 1946). 
Mais recentemente, estudos têm mostrado essa associação (ISMAIL et al. 1993; VILLA et al. 1998), mas outros destacaram a importância de se ter controle sobre essa exposição, principalmente pelo fato das pessoas mudarem seu local de residência (GONINI 1999). Em muitas situações, as famílias optam pelo uso de águas minerais engarrafadas que podem ter teores de flúor variáveis (TOUMBA e COURZON 1994; VILLENA et al. 1996; HEINTZE e BASTOS 1996).

No presente estudo observou-se associação estatisticamente significativa entre o consumo de água para ingestão no terceiro ciclo e a ocorrência de fluorose dentária (Tabela 15). Quando se estabeleceu a continuidade da exposição ao longo dos ciclos, e se isolou a água encanada das demais, essa associação não foi observada (Tabela 36).

Com a água utilizada para o preparo de alimentos, foi observada associação estatística significativa com a ocorrência de fluorose dentária nos três ciclos (Tabela 16). Ao se isolar a água encanada das demais fontes ao longo dos ciclos, essa associação se manteve (Tabela 36). Por outro lado, foi observada associação com utilização de outras fontes de água (engarrafadas provenientes de fontes de água mineral e outras), onde a fonte de água encanada utilizada de forma irregular foi incluída.

Estes resultados vão ao encontro do que foi apontado por GRIMALDO et al. (1995) que observaram, no México, que as crianças que utilizavam água de abastecimento público no preparo de alimentos estavam expostas a níveis mais elevados de flúor. Ainda HEILMAN et al. (1997) apontaram que a água utilizada no preparo de alimentos (no caso, de cereais) era o maior determinante dos níveis de flúor.

Essas observações, associadas às de FULL e PARKINS (1975) e RIBEIRO (1992) de que a evaporação que acontece durante o cozimento é uma fonte potencial de maior concentração de flúor em soluções, mostraram a coerência dos resultados obtidos na presente pesquisa.

Em relação ao uso de filtro para água, quando se analisou a exposição ao longo dos ciclos, observou-se associação estatística com a 
ocorrência de fluorose dentária, mas esta se deu com o uso irregular em um ou mais ciclos, o que dificultaria a análise (Tabela 36). Na literatura, a única citação em relação à filtragem de água foi feita por WINKLE et al. (1995), quando observaram que esse procedimento realizado no preparo de fórmulas em pó, não interferiu nos níveis de flúor. Esse aspecto merece estudos com o controle dessa variável.

\subsection{Fatores relacionados ao uso de dentifrícios}

Neste estudo foram avaliados os seguintes aspectos relacionados ao uso de dentifrícios em cada ciclo: tipo, idade de início de uso, tamanho da cabeça da escova dental, quantidade utilizada, ingestão, responsável pela colocação, número de escovações diárias e número de enxágües após a escovação.

Em relação ao uso de dentifrício fluoretado, quando se categorizou a exposição por número de ciclos (Tabela 37) e se analisou de forma geral não se observou associação estatística significativa. Porém, ao se analisar cada categoria (Tabela 39) observou-se associação estatisticamente significativa com o uso de dentifrício fluoretado em dois e em três ciclos, com uma associação próxima da significância estatística no primeiro ciclo, caracterizando a força da continuidade da exposição.

Associações da fluorose dentária com a exposição a dentifrícios têm sido observadas em locais com água fluoretada em diferentes períodos: do nascimento até 8 anos de idade (PENDRYS et al. 1994), três primeiros anos de vida (CLARK e BERKOWITZ 1997), antes dos 6 anos de idade com aumento significativo de severidade se esse uso tivesse ocorrido antes dos 2 anos de idade (MASCARENHAS e BURT 1998). Também foram encontradas e em locais sem água não fluoretada no período entre 1 e 2 anos de idade (PENDRYS et al. 1996).

Variações de períodos de exposição a dentifrícios fluoretados e sua associação com a fluorose dentária podem ser observadas nos estudos citados e no presente estudo, porém a sua associação com a continuidade 
da exposição como foi observado na presente pesquisa não foi destacada em nenhum dos estudos consultados. Estudos semelhantes em áreas com água não fluoretada como o de PENDRYS et al. (1996) necessitam ser conduzidos para confirmar os resultados encontrados .

Em relação à idade de início do uso de dentifrício, não houve diferenças entre casos e controles (Tabela 32). Optou-se por estabelecer a idade de risco em cada ciclo, mas não foi observada associação estatística significativa (Tabela 37).

Esses resultados foram diferentes dos encontrados por PENDRYS et al. (1996), realizado em área não fluoretada, que observaram maior associação quando o início do uso de dentifrício se deu entre o primeiro e o segundo ano de vida. O mesmo foi identificado por MASCARENHAS e BURT (1998), que encontraram associação estatística significativa quando as crianças iniciaram o uso de dentifrício antes de 2 anos de idade.

Os resultados da presente pesquisa são semelhantes aos de GONINI (1999), que não encontrou associação entre fluorose dentária e o início do uso de dentifrícios antes dos 24 meses de vida, ou mesmo entre 25 e 36 meses de idade, explicada pela autora pelo fato de ter sido consumido dentifrícios sem flúor. Essa hipótese não se aplicaria à população estudada, pois a maioria consumiu dentifrício fluoretado (Tabela 28)

No que diz respeito ao tamanho da cabeça da escova, não foi observada associação estatística significativa com a ocorrência de fluorose dentária em nenhum dos ciclos (Tabela 31), nem quando se categorizou o tamanho ao longo dos ciclos (Tabela 37).

$\mathrm{Na}$ literatura consultada, não foram encontrados estudos que tivessem feito esse levantamento. Apenas RIPA (1991) sugeriu que o uso de escovas com cabeça superdimensionada poderia estimular a colocação de maiores quantidades de dentifrício. Por isso recomendou, para crianças, o uso de escovas com cabeças pequenas. Embora não se tenha observado associação estatística significativa entre essa variável e a ocorrência de fluorose dentária, esse é um aspecto que merece maiores investigações. 
Em relação à quantidade de dentifrício dispensada na escova, a princípio, observou-se associação estatística significativa com a ocorrência de fluorose dentária no terceiro ciclo (Tabela 29). Ao se estabelecer uma quantidade de risco para cada ciclo, a associação não se manteve (Tabela $39)$.

GONINI (1999) também não encontrou associação estatística significativa com fluorose dentária quando comparou crianças que usaram menos de $0,25 \mathrm{~g}$ de dentifrício com as que usaram mais do que isto, em uma amostra onde foram considerados os três primeiros anos de vida.

No presente estudo, essa categoria $(0,25 \mathrm{~g})$ considerada por DEN BESTEN e KO (1996) como recomendada para crianças com risco de desenvolver fluorose dentária foi referência como dose de risco para o primeiro ano de vida e apareceu em apenas 9 respostas $(1,8 \%)$, o que impossibilitou comparações. $O$ estabelecimento da dose de risco para cada faixa etária é importante, pois a intoxicação está relacionada ao peso da criança.

A relação entre a quantidade de dentifrício dispensada na escova e a quantidade ingerida, bem como a sua associação com a idade das crianças, foi tratada em vários estudos (BARNHART et al. 1974, EKSTRAND et al. 1983; SIMARD et al. 1989; RIPA 1991 e LEVY et al. 1992).

No presente estudo, esse aspecto não foi identificado, uma vez que exige a utilização de métodos laboratoriais de análises. Em relação à ingestão, apenas se buscou colher a percepção dos entrevistados, notandose pelos resultados que isso não foi observado ou realmente não aconteceu, ou até mesmo não foi lembrado (item 5.20).

Em relação ao responsável pela colocação do dentifrício, em uma análise geral, observou-se associação estatisticamente significativa com a fluorose dentária no terceiro ciclo (Tabela 30). Porém, considerou-se adequado analisar essa responsabilidade ao longo dos ciclos, isolando-se o terceiro ciclo. A associação entre fluorose dentária e o fato da criança ser a 
responsável pela colocação do dentifrício no terceiro ciclo, permaneceu significativa (Tabela 37).

Ao propor a produção de um guia de orientações sobre o uso de dentifrícios, RIPA (1991) destacou a importância de que os responsáveis pela criança cuidassem da colocação do dentifrício na escova enquanto elas não tivessem consciência dos riscos, e que supervisionassem a escovação a partir da idade escolar. Esse aspecto também foi destacado por SJÖEGREN et al. (1994) e LEVY et al. (1995 $\left.{ }^{\mathrm{b}}\right)$.

Outro ponto que reforça essa necessidade é a presença de corantes e flavorizantes nos dentifrícios, que acabam estimulando a colocação de maiores quantidades, ou até mesmo a ingestão do produto (SPEAR e SAVISKY 1991; LEVY et al. 1992; DEN BESTEN e KO 1996). Nesse sentido, cabe ressaltar a importância da participação dos produtores de dentifrícios em relação ao conteúdo e às formas de propaganda impressa e visual (LEVY et al. 1995 ${ }^{\mathrm{b}}$; CHEDID et al. 2003).

Outro aspecto que merece cuidados diz respeito ao uso de dentifrícios com menores concentrações de flúor, conforme sugerido por RIPA (1991). Dependendo da idade e peso da criança, essa concentração de flúor pode representar risco para fluorose dentária $\mathrm{e}$ isso deve ficar claro nas embalagens e propagandas. Também não pode ser desconsiderada a preocupação de LEVY et al. (1995 ${ }^{\text {b }}$ em relação ao fato de se recomendar, para crianças, somente o uso de dentifrícios sem flúor e isso se tornar uma panacéia, pois estariam sendo eliminados os benefícios pós-eruptivos do flúor na dentição decídua.

Essa é uma decisão que deve ser analisada em dois níveis: individual e coletivo. No nível individual, quando se tem controle sobre hábitos alimentares e de higiene, essa decisão pode ser tomada, mas, em nível coletivo, pode ser comprometedora, pois muitas vezes, a única exposição a flúor pode advir do dentifrício.

Em relação à freqüência diária de escovação não foi observada diferenças entre casos e controles (Tabela 32). Ao estabelecer freqüências 
de risco para cada ciclo e analisar ao longo dos ciclos também não foram observadas diferenças estatisticamente significativas (Tabela 37),

Esses resultados foram semelhantes aos de BARDSEN et al. (1999), que também não encontraram associação significativa entre a freqüência de escovação e a fluorose dentária mas são diferentes dos encontrados por PENDRYS et al. (1996) que estabeleceram freqüências para o período de 1 a 2 anos de idade (uma vez ao dia) e após os 2 anos de idade (mais de uma vez ao dia), e encontraram associação do uso precoce e contínuo de dentifrício fluoretado (mais de uma vez ao dia) com a prevalência fluorose dentária quando comparado com uma única vez .

No presente estudo utilizou-se como padrão para estabelecer limites em cada ciclo a freqüência diária de três vezes, pois os valores médios diários giram em torno de duas vezes nos segundo e terceiros ciclos (Tabela 32).

Não houve diferença estatisticamente significativa entre casos e controles e a média de enxágües após a escovação em cada ciclo (Tabela 32), embora alguns estudos apontem a importância desse fator em relação à diminuição da ingestão de dentifrício (SIMARD et al. 1989: SJÖEGREN et al. 1994; NACACCHE et al. 1992; ADAIR et al. 1997).

Faz-se necessário, a partir dos resultados desta pesquisa, a elaboração de um instrumento de coleta mais simples, que contemple os ciclos de vida e garanta a obtenção de dados sobre a continuidade da exposição a fontes múltiplas de flúor; a fim de facilitar a condução de futuras pesquisas em locais com e sem água fluoretada. Além disso, a inclusão para a seleção dos casos de critérios que contemplem os períodos de exposição e de formação do esmalte (FRI) complementaria as análises.

As políticas públicas adotadas no município de Ribeirão Pires - SP poderão utilizar os resultados como subsídio no planejamento e avaliação das ações de saúde bucal, bem como as ações intersetoriais com efeitos, direto e indireto, sobre a exposição da população aos fatores identificados. 


\section{CONSIDERAÇÕES FINAIS}

Com relação aos objetivos desta investigação, e tendo em vista os resultados aqui discutidos, pode-se afirmar que os fatores associados à ocorrência de fluorose dentária na população estudada foram: uso de dentifrício fluoretado nos seis primeiros anos de vida $(O R=2,25$; IC95\%=1,10-5,00; $p=0,048)$ e criança como responsável pela sua colocação no período de 4 a 6 anos de idade (OR=2,17; IC95\%=1,41-3,32; $p=0,000)$; utilização de água fluoretada para preparo de alimento nos 6 primeiros anos de vida $(O R=2,90 ; \quad I C 95 \%=1,42-5,55 ; p=0,026)$ e interação entre maior escolaridade do pai e menor escolaridade da mãe $(O R=2,15$; IC95\%=1,11$4,17 ; p=0,024)$.

Admite-se que os níveis de saúde-doença das populações são influenciados por determinantes ambientais, comportamentais, de organização dos serviços e biológicos. Entre os determinantes ambientais investigados na presente pesquisa, foi observado que a escolaridade do pai e a da mãe exerceram influência indireta no evento, alterando o risco de ocorrência de fluorose dentária decorrente do uso contínuo de dentifrício fluoretado (determinante sócio-econômico), da criança como responsável pela sua colocação (determinante comportamental) e da água para preparo de alimentos (determinante sócio-econômico e comportamental).

Os valores da Odds Ratio (OR) relativos aos dentifrícios fluoretados, uma das múltiplas fontes de flúor utilizadas a partir da segunda metade do século XX, mostraram que a ocorrência da fluorose dentária pode ser atribuída ao seu emprego, confirmando a necessidade de cuidados na sua utilização na primeira infância.

Em relação ao responsável pela colocação do dentifrício, os resultados obtidos apoiaram a tese de uma interação em sentido contrário entre a escolaridade do pai e a escolaridade da mãe; sugerindo que a combinação do nível mais elevado de escolaridade do pai com o nível mais baixo de escolaridade da mãe pode elevar o risco que representa o fato da colocação do dentifrício pela criança na ocorrência da fluorose dentária. 
No nível coletivo, tanto em relação ao uso de dentifrícios quanto ao tipo de água utilizada no preparo de alimentos, podem ser identificadas medidas de competência loco-municipal e medidas mais amplas.

Dentro da competência loco-municipal, pode ser citada a inclusão em atividades educativas realizadas em unidades de saúde ou em espaços coletivos, da discussão e orientação sobre a importância da participação dos pais e/ou responsáveis na colocação do dentifrício fluoretado na escova dental; até o momento em que a criança tenha consciência desse cuidado. De forma mais ampla, o estímulo aos fabricantes no sentido de esclarecerem nos seus produtos os riscos e cuidados na sua utilização deve ser uma política nacional.

Em conseqüência dos resultados obtidos, recomenda-se que os serviços mantenham ações de educação em saúde voltadas ao uso correto de produtos fluoretados e a política de vigilância sanitária dirigida às múltiplas fontes de flúor.

Além disso, o controle sobre a aplicação de produtos fluoretados em ações coletivas, bem como a implantação de sistemas de informação que permitam a documentação do desenvolvimento dessas ações são aspectos a serem considerados.

Levando-se em conta o princípio da eqüidade, também não pode ser desprezada a questão da recuperação dos indivíduos atingidos pelo agravo, principalmente para aqueles nos quais o comprometimento estético possa representar redução de acesso e de oportunidades e exclusão social. Nesse sentido, investimentos em medidas recuperadoras devem ser avaliados.

Por fim, recomenda-se a realização de estudos semelhantes em locais sem flúor em nível ótimo, nas águas de abastecimento. 


\section{REFERÊNCIAS}

1. Adair SM, Piscitelli WP, McKnnight-Hanes C. Comparison of use of a child and adult dentifrice by a sample of preschool children. Pediatric Dent 1997; 19(2): 99-103.

2. Alcaide AL, Veronezi O. Prevalência de fluorose dental na cidade de Icém. Rev Ass Paul Cirurg Dent 1979; 33(1): 90-5.

3. Alcântara CM. Prevalência de fluorose dentária em escolares de Curitiba. DENS 1996; 12: 45-54.

4. Almeida Filho N. For a General Theory of Health: preliminary epistemological and anthropological notes. Cad Saúde Pública 2001; 17(4): 753-99.

5. Ando T, Cardoso $\mathrm{MH}$, Andrade JLR. Alguns aspectos da fluorose dentária. Rev Fac Odont S Paulo 1975; 13(2): 269-76.

6. Antia NJ, Klut ME. Fluoride addition effects on Euryhaline Phytoplankter growth in nutrient enriched seawater at an estuarine level of salinity. Botanica Marina. 1981; 24: 147-52.

7. Aoba T. The effect of fluoride on apatite structure and grow. Crit Rev Oral Biol Med 1997; 8(2): 136-53.

8. Aoba T; Fejerskov O. Dental fluorosis: chemistry and biology. Crit Rev Oral Biol Med 2002; 13(2): 155-70.

9. Awadia AK, Haugejorden O, Bjorvatn K, Birkeland JM. Vegetarianism and dental fluorosis among children in a high fluoride area of northern Tanzania. Int J Paediatric Dent 1999; 9: 3-11.

10. Awadia AK, Bjorvatn K, Birkeland JM, Haugejorden O. Weaning food and magadi associated with dental fluorosis in Northern Tanzania. Acta Odontol Scand 2000; 58(1); 1-7.

11. Bagramian RA, Narendran S, Ward M. Relationship of dental caries and dental fluorosis to fluoride supplement history in a non-fluoridated sample of schoolchildren. Adv Dent Res 1989; 3(2):161-7. 
12. Bardsen A. Risk periods associated with the developmental of dental fluorosis in a maxillary permanent central incisors: a meta-analysis. Acta Odontol Scand 1999; 57(5): 247-56.

13. Bardsen A, Klock KS, Bjorvatn K. Dental fluorosis among persons exposed to high- and low-fluoride drinking water in western Norway. Community Dent Oral Epidemiol 1999; 27: 259-67.

14. Barnhart WE, Hiller K, Leonard GJ, Michaels SE. Dentifrice usage and ingestion among four age groups. J Dent Res 1974; 53(6): 1317-22.

15. Bastos JRM, Lopes ES, Freitas SFT. Panorama mundial após 50 anos de uso do flúor. RGO 1993; 41(5): 309-11.

16. Bawden JW. "Where is Waldo?" The timing of fluorosis. J Public Health Dent 1996; 56: 5.

17. Bowen WH. Fluorosis: is it really a problem?. J Amer Dent Assoc 2002; 133: 1405-7.

18. Brasil. Ministério da Fazenda. Receita Federal. Imposto de renda Pessoa física - 2003. Brasil: Governo federal; 2003 [Manual de preenchimento da declaração de ajuste anual; modelo completo para o ano-calendário de 2002].

19. Brasil. Ministério da Saúde. Conselho Nacional de Saúde. Resolução $n^{\circ}$ 196, 10/10/1996. [Regulamenta pesquisas envolvendo seres humanos].

20. Brasil. Senado Federal. Subsecretaria de Informações. Poder Legislativo. Lei Federal no 8.080, 19/09/1990. Diário Oficial da União. 20 set 1990, p. 108055, col. 1. [Lei Orgânica da Saúde. Dispõe sobre as condições para a promoção, proteção e recuperação da saúde, a organização e o funcionamento dos serviços correspondentes e dá outras providências].

21. Broglio LAZ. Estudo cinético do efeito do flúor sangüíneo e ósseo na incorporação ao esmalte dental de animais (Rattus novergicus var. albinus) previamente expostos ou não submetidos a uma dose única. 
Piracicaba; 1994. [Tese de Doutorado - Faculdade de Odontologia da UNICAMP].

22. Brothwell DJ, Limeback $\mathrm{H}$. Fluorosis risk in grade 2 students residing in a rural area with widely natural fluoride. Community Dent Oral Epidemiol 1999; 27(2): 196-9.

23. Buendia OC. Fluoretação de águas: manual de orientação prática. São Paulo: American Med; 1996.

24. Burt BA. The changing patterns of systemic fluoride intake. J Dent Res 1992; 71(Spec Iss): 1228-37.

25. Burt BA. The case for eliminating the use of dietary fluoride supplements for young children. J Public Health Dent 1999; 59(4): 269-74.

26. Buzalaf MAR, Bastos JRM, Granjeiro JM, Levy FM, Cardoso VES, Rodrigues MHC. Fluoride contend of several brands of teas and juices found in Brazil and risk of dental fluorosis. Rev Fac Odontol Bauru 2002; 10(4): 263-7.

27. Buzalaf MAR, Granjeiro JM, Cardoso VES, Silva TLS, Olympio KPK. Fluoride contend of several brands of chocolate bars and chocolate cookies found in Brazil. Pesqui Odontol Bras 2003; 17(2): 223-7.

28. [BVS] Biblioteca Virtual em Saúde. Descritores em Ciências da Saúde. Disponível em <URL: http://www.decs.bvs.br/cgibin/wxis1660.exe/decssserver/> [2001 Out 04].

29. Camargo JA, Tarazona JV. Short-term toxicity of fluoride ion (F-) in soft water to rainbow trout (Salmo gairdneri) and brown trout (Salmo trutta fario). Fluoride. 1991; 24: 76-84.

30. Cangussu MCT. Cárie e fluorose dentária em adolescentes de 12 a 15 anos em Salvador, Bahia, no ano de 2001. São Paulo; 2003. [Tese de Doutorado - Faculdade de Saúde Pública da USP].

31. Cao J, Zao Y, Liu J, Xirao R, Danzeng S. Enviromental fluoride content in Tibet. Environ Res 2000; 83(3): 333-7. 
32. Capella LF, Carcereri DL, Paiva SM, Rosso RA, Paixão RF, Saltori EK. Ocorrência de fluorose dentária endêmica: constatação de uma comunidade afetada por fluorose dentária - Distrito de Cocal Urussunga/SC - e levantamento de seu índice. RGO 1989; 37(5): 371-5.

33. Cardoso VES, Olympio KPK, Granjeiro JM, Buzalaf MAR. Fluoride contend of several breakfast cereals and found in Brazil. J Appl Oral Sci 2003; 11(4): 306-10.

34. Causeret J. Fish as a source of mineral nutrition. In: Borgstrom G. Fish as food. New York. Academic Press. 1962; 205-34.

35. [CDC] Centers for Disease Control ad Prevention. Recommendations for using fluoride to prevent and control dental caries in the United States. Atlanta: CDC; 2001. Disponível em <URL: http//www.cdc.gov/nccdphp/oh/flfactwf2.htm/> [2001 October 24].

36. [CDC-WHO] Centers for Disease Control ad Prevention - World Health Organization. Epi Info. Epidemiologia em microcomputadores: um sistema de processamento de texto, banco de dados e estatísticas [programa de computador]. Atlanta: OPAS/WHO; 1990.

37. Chan JT, Yip TT, Jeske AH. The role of caffeinated beverages in dental fluorosis. Med Hypotheses 1990; 33(1): 21-2.

38. Chaves MM. Odontologia social. Rio de Janeiro: Labor do Brasil S.A.; 1986.

39. Chedid SJ. Avaliação da quantidade de dentifrício fluoretado ou $\mathrm{NaF} \mathrm{a}$ 0,02\% no desenvolvimento de cárie em dentes decíduos - Estudo in vitro utilizando modelos de ciclagem de pH. São Paulo; 1999. [Tese de Doutorado - Faculdade de Odontologia da USP].

40. Chedid SJ, Guedes-Pinto AC, Narvai PC, Forni TIB. Flúor - uso interno. In: Guedes-Pinto AC Odontopediatria. Santos: São Paulo; 2003. p. 383-432.

41. Churchill HV. Occurrence of fluorides in some waters of United States. Ind Eng Chem 1931; 23:996-8. 
42. Clark DC, Berkowitz J. The influence of various fluoride exposures on the prevalence of esthetic problems resulting from dental fluorosis. $J$ Public Health Dent 1997; 57(3): 144-9.

43. Cury JA. Concentração de fluoreto em chás brasileiros e seu significado na prevenção da cárie dentária. RGO 1981; 29(2):136-8.

44. Cury J. Manipulando o flúor com segurança - Parte III - Toxicidade crônica. Jornal da ABOPREV. Rio de Janeiro, 1995, jan./fev./mar., p.10.

45. Dean HT (1933). Distribution of mottled enamel in the United States. In: McClure FJ (Editor) Fluoride drinking waters. Maryland: USPHS; 1962. p.11-23.

46. Dean HT (1934). Classification of mottled enamel diagnosis. In: McClure FJ (Editor) Fluoride drinking waters. Maryland: USPHS; 1962. p.23-6.

47. Dean HT (1936). Chronic endemic dental fluorosis (mottled enamel). In: McClure FJ (Editor) Fluoride drinking waters. Maryland: USPHS; 1962. p.45-9.

48. Dean HT. The investigation of physiological effects by the epidemiological method. In: Moulton FR (Editor) Fluorine and dental health. Washington: AAAS; 1942. p.23-31.

49. Dean HT. Endemic dental fluorosis or mottled enamel. J Am Dent Assoc 1943; 30(16): 1278-84.

50. Dean HT. Epidemiological studies in United States. In: Moulton FR (Editor) Dental caries and fluorine. Lancaster: AAAS; 1946. p.5-31.

51. Dean HT, Dixon RM, Cohen C (1935). Mottled enamel in Texas. In: McClure FJ (Editor) Fluoride drinking waters. Maryland: USPHS; 1962. p.26-35.

52. Dean HT, Elvolve E (1935). Studies on the minimal threshold of dental sign of chronic endemic fluorosis (mottled enamel). In: McClure FJ (Editor) Fluoride drinking waters. Maryland: USPHS; 1962. p.36-40. 
53. Dean HT, Elvolve E (1936). Some epidemiological aspects of chronic endemic dental fluorosis. In: McClure FJ (Editor) Fluoride drinking waters. Maryland: USPHS; 1962. p.41-5.

54. Dean HT, Elvolve E (1937). Further studies on the minimal threshold of chronic endemic dental fluorosis. In: McClure FJ (Editor) Fluoride drinking waters. Maryland: USPHS; 1962. p.49-56.

55. Dean HT, Elvolve E; McKay FS (1938). Mottled enamel survey of Bauxite, Ark., 10 years after a change in the common water supply. In: McClure FJ (Editor) Fluoride drinking waters. Maryland: USPHS; 1962. p. 56-62.

56. Dean HT, Elvolve E, Poston RF (1939). Mottled enamel in South Dakota. In: McClure FJ (Editor) Fluoride drinking waters. Maryland: USPHS; 1962. p.62-71.

57. Dean HT, McKay FS (1939). Production of mottled enamel halted by a change in common water supply. In: McClure FJ (Editor) Fluoride drinking waters. Maryland: USPHS; 1962. p.71-4.

58. de Liefde B, Herbison GP. Prevalence of developmental defects of enamel and dental caries in New Zealand children receiving differing fluoride supplementation. Community Dent Oral Epidemiol 1985; 13 : 164-7.

59. Den Besten P, Ko HS. Fluoride levels in whole saliva of preschool children after brushing with 0,25 (pea-sized) as compared to 1,0 (fullbrush) of a fluoride dentifrice. Pediatric Dent 1996; 18(4): 17-21.

60. Denver GEA. Epidemiologia: enfocando a prevenção. In: Denver GEA. A epidemiologia na administração dos serviços de saúde pública. São Paulo: Pioneira; 1988. p.1-24.

61. Eager JM. Denti di Chiaie teeth (Chiaie teeth) (1901). In: McClure FJ (Editor) Fluoride drinking waters. Maryland: USPHS; 1962. p.2.

62. Eklund AS, Burt BA, Imail Al, Calderone JJ. High-fluoride drinking water, fluorosis and dental caries in adults. J Amer Dent Assoc 1987; 114: 324-8. 
63. Ekstrand J, Ehrnebo M. absorption of fluoride dentifrices. Caries Res 1980; 14: 96-102.

64. Ekstrand J, Koch G, Petersson LG. Plasma concentrations in preschool children after ingestion of fluoride tablets and toothpaste. Caries Res 1983; 17: 379-84.

65. Ekstrand J, Spack CJ, Falch J, Afseth J, Ulveastad H. Distribution of fluoride to human breast milk. Caries Res 1984; 18: 93-5.

66. El Nadeef MAF, Honkala E. Fluorosis in relation to fluoride levels in water in central Nigeria. Community Dent Oral Epidemiol 1998; 26: 2630.

67. Evans RW, Stamm JW. Dental fluorosis following downward adjustment of fluoride drinking water. J Public Health Dent 1991; 51(2): 91-8.

68. Fejerskov O, Thylstrup A, Larsen MJ. Clinical and strutural features and possible pathogenic mechanisms of dental fluorosis. Scand Dent Res 1977; 85: 510-34.

69. Fejerskov O, Baelum V, Manji F, Moller IJ. Fluorose dentária - um manual para profissionais de saúde. São Paulo: Santos; 1994.

70. Forni TIB. Caracterização de levantamentos epidemiológicos de fluorose dentária no Estado de São Paulo. São Paulo; 2000. [Dissertação de Mestrado - Faculdade de Saúde Pública da USP].

71. Frazão P. Epidemiologia da oclusão dentária na infância e os sistemas de saúde. São Paulo; 1999. [Tese de Doutorado Faculdade de Saúde Pública da USP].

72. Frazão P, Peverari AC, Forni TIB, Mota AG, Costa LR. Fluorose dentária: comparação de dois estudos de prevalência. Cad Saúde Pública 2004; 20(4): 1050-1058.

73. Full CA, Parkins FM. Effect of cooking vessel composition on fluoride. J Dent Res 1975; 54(1): 192. 
74. Galagan DJ, Lamson GGJ (1953). Climate and endemic dental fluorosis. In: McClure FJ (Editor) Fluoride drinking waters. Maryland: USPHS; 1962. p.74-82.

75. Galagan DJ, Vermillion JR. Determining optimum fluoride concentrations. Pub Health Rep 1957; 72(6): 491-3.

76. Gil AC. Projetos de pesquisa. São Paulo: Atlas; 1996.

77. Gikunju JK. Fluoride concentration in Tilapia fish (Oreochromis leucostictus) from lake Naivasha, Kenya. Fluoride. 1992; 25(1): 37-43.

78. Gonini CAJ. Fluorose dentária em crianças nascidas entre 1986 e 1989, usuárias da rede de unidades básicas de saúde de Londrina: freqüência, severidade e fatores associados. Londrina; 2000. [Dissertação de Mestrado - Faculdade de Odontologia da UEL].

79. Granath L, Widenhein J, Birkhed D. Diagnosis of mild enamel fluorosis in permanent maxillary incisors using two scoring systems. Community Dent Oral Epidemiol 1985; 13(5): 273-6.

80. Grimaldo M, Borja-Arbuto VH, Ramirez AL, Ponce MR, Díaz-Barriga F. Endemic fluorosis in San Luis Potosi, Mexico. Environ Res 1995; 68: 25-30.

81. Hayacibara MF, Queiroz CS, Tabchoury CPM, Cury JA. Fluoride and aluminum in teas and tea-based beverages. Rev Saúde Pública 2004; 38(1):100-5.

82. Heilman JR, Kiritsy MC, Levy SM, Wefel JS. Fluoride concentrations of infants foods. J Am Dent Assoc 1997; 128: 857-63.

83. Heilman JR, Kiritsy MC, Levy SM, Wefel JS. Assessing fluoride levels of carbonated soft drinks. J Am Dent Assoc 1999; 128: 1593-9.

84. Heintze SD, Bastos JRM. Avaliação do teor de flúor e pH em bebidas do mercado nacional. Rev Assoc Paul Cir Dent 1996; 50(4):339-45.

85. Hemens J, Warwick RJ. The effects of fluoride on estuarine organisms. Water Research. 1972; 6:1301-1308 .

86. Holt RD, Murray JJ. Developments in fluoride toothpastes - an overview. Community Dent Oral Epidemiol 1996; 14: 4-10. 
87. Horowitz HS. The need for toothpaste with lower conventional fluoride concentrations for preschool-aged children. J Public Health Dent 1992; 52(4): 216-21.

88. Horowitz HS. Commentary on and recommendations for the proper uses of fluoride. J Public Health Dent 1995; 55(1): 57-62.

89. Horowitz HS, Driscoll WS, Meyers RJ, Heiftz SB, Kingman A. A new method for assessing the prevalence of dental fluorosis - the Tooth Surface Index of Fluorosis. J Amer Dent Assoc 1984; 109: 37-41.

90. Ismail Al. Fluoride supplements: current effectiveness, side effects and recomendations. Community Dent Oral Epidemiol 1994; 22: 16472 .

91. Ismail Al, Bandekar RR. Fluoride supplements and fluorosis: a metaanalyses. Community Dent Oral Epidemiol 1999; 27(1): 48-56.

92. Ismail AI, Shoveller J, Langille D, MacInnis WA, McNally M. Should the drinking water of Truro, Nova Scotia, be fluoridated? Water fluoridation in the 1990s. Community Dent Oral Epidemiol 1993; 21:118-25.

93. Johnston DW. Current status of professionally applied topical fluorides. Community Dent Oral Epidemiol 1994; 22: 159-63.

94. Kempf GA, McKay FS (1930). Mottled enamel in a segregated population. In: McClure FJ (Editor) Fluoride drinking waters. Maryland: USPHS; 1962. p. 2-10.

95. Kimmelman BB. Fluoride: is there a limit? Compendium 1995; 16(4): 376-93.

96. Kleinbaum DG, Kupper LL, Muller KE. Multiple regression analysis: general considerations. In: Kleinbaum DG, Kupper LL, Muller KE. Applied regression analysis and other multivariable methods. Belmont: Duxbury Press, 1988. p.102-23.

97. Lee ENC, Vono AZ, Pinheiro CE, Bijella MFTB, Silva SMB. Efeito do mate e do chá, comparado aos do flúor na prevenção da cárie em ratos. Estomatol cult 1986; 16(2): 17-22. 
98. Lefevre F. "Você deixaria sua filha se casar com um negro?" Algumas considerações sobre a ambigüidade na questões de pesquisa. Saúde e Sociedade 1994; 3(2): 186-96.

99. Levy SM. Rewiew of fluoride exposures and ingestion. Community Dent Oral Epidemiol 1994; 22: 173-80.

100. Levy SM, Guha-Chowdhury N. Total fluoride intake and implications for dietary supplementation. J Public Health Dent 1999; 59(4): 211-23.

101. Levy SM, Zarei-M Z. Evaluation of fluoride exposures in children. ASDC J Dent Child 1991; 58(6): 467-73.

102. Levy SM, Kohout EJ. Guha-Chowdhury N, Kiritsy MC, Heilman JR, Wefel JS. Infants' fluoride intake from drinking water alone, and from water added to formula, beverages, and food. J Dent Res 1995 a 74(7): 1399-1407.

103. Levy SM, Kiritsy MC, Warren JJ. Sources of fluoride intake in children. J Public Health Dent 1995' ; 55(1): 39-52.

104. Levy SM, Kiritsy MC, Slager SL, Warren JJ, Kohout FJ. Patterns of fluoride dentifrice among infants. Pediatric Dent 1997; 19(1): 50-5.

105. Levy SM, Maurice TJ, Jackobsen JR. A pilot study of preschoolers' use of regular-flavored dentifrices and those flavored for children. Pediatric Dent 1992; 14(6): 388-91.

106. Lewis DW, Banting DW. Water fluoridation: current effectiveness and dental fluorosis. Community Dent Oral Epidemiol 1994; 22: 153-8.

107. Loyola-Rodriguez JP, Pozos-Guillén AJ, Hernandez-Guerrero JC. Bebidas embotelladas como fuentes adicionales de exposición a flúor. Salud Pública de México 1998; 40(5): 438-41.

108. Mabelya L, van Palenstein Helderman WH, van't Hof MA, Köning KG. Dental fluorosis and the use of a high fluoride-containing trona tenderizer (magadi). Community Dent Oral Epidemiol 1997; 25: 170-6.

109. Malde MK, Maage A, Macha E, Julshamn K, Bjorvan K. Fluoride content in selected food items from five areas in East Africa. $J$ Food Comp Anal. 1997; 10: 233-45. 
110. Maltz M, Silva BB. Relação entre cárie, gengivite e fluorose e nível socioeconômico em escolares. Rev Saúde Pública 2001; 35(2): 170-6.

111. Mascarenhas AK. Risk factors for dental fluorosis: a review of the recent literature. Pediatric Dent 2000; 22(4):269-77.

112. Mascarenhas AK, Burt BA. Fluorosis risk from early exposure to fluoride toothpaste. Community Dent Oral Epidemiol 1998; 26: 241-8.

113. Mckay FS. The establishment of a definitive relation between enamel that is defective in its structure, as mottled enamel, and the liability to decay. Dental Cosmos 1929; 71(8): 747-55.

114. McKay FS. Mottled enamel: the prevention of its further production through a change of water supply at Oakley, Ida. J Am Dent Assoc 1933; 20(7): 1137-49.

115. Mckay FS, Black GV. Mottled teeth: an endemic developmental imperfection of the enamel of the teeth heretofore unknown in the literature of dentistry. Dental Cosmos 1916 ; 58(2): 12956-84.

116. Mckay FS, Black GV. An investigation of mottled teeth: and endemic developmental imperfection of enamel of teeth, heretofore unknown in the literature of dentistry. Dental Cosmos 1916 ${ }^{\text {b }}$; 58(5): 477-84.

117. Mella OS, Molin MX, Atalah SE. Prevalencia de fluorosis dental endemica en relacion al contenido de fluoruros en las aguas de abasto publico. Rev Med Chile 1994; 122: 1263-70.

118. Menezes LMB, Sousa MLR, Rodrigues LKA; Cury JA. Autopercepção da fluorose pela exposição a flúor pela água e dentifrício. Rev Saúde Pública 20002; 36(6):752-4.

119. Moysés SJ, Moysés S, Allegretti ACV, Argenta M, Werneck R. Fluorose dental: ficção epidemiológica? Rev Panan Salud Publica 2002; 12(5):339-46.

120. Naccache H, Trahan L, Brodeur JM, Demers M, Lachapelle D. Factors affecting the ingestion of fluoride dentifrice by children. $J$ Public Health Dent 1992; 52(4): 222-6. 
121. Narvai PC. Fluorose dental: nova síndrome odontológica? (Simpósio) VI Jornada Odontológica de Piracicaba. Piracicaba, SP, 04/10/1999.

122. Narvai PC. Fluorose dentária iatrogênica endêmica. Rev Bras Epidemiol 2002; Supl. Esp.:387.

123. Nell JA, Livanos G. Effects of fluoride concentration in seawater on growth and fluoride accumulation by Sidney rock oyster (Saccostrea comercialis) and flat oyster (Ostrea angasi) spat. Wat Res 1988; 22(6): 749-53.

124. Nettleton J. Seafood nutrition: facts, issues and marketing of nutrition in fish and shellfish. $2^{\mathrm{a}}$ ed. D Sc RD. 1944.

125. Newbrun E. Current regulations and recommendations concerning water fluoridation, fluoride supplements, and topical fluoride agents. $J$ Dent Res 1992; 71(5): 1255-65.

126. Oehlenschläger $\mathrm{J}$, Manthey $\mathrm{M}$. Fluoride content of Antarctic maine animals caught off Elefhant Island. Polar Biol 1982; 1: 125-27.

127. Opinya GN, Bwibo N, Valderhaug J, Birkeland JM, Lökken P. Intake of fluoride and excretion in mothers' milk in a high fluoride (9 ppm) area in Kenya. Eur J Clin Nutr 1991; 45: 37-4.

128. Osuji OO, Leake JL, Chipman ML, Nikiforuk G, Locker D, Levine N. Risk factors for dental fluorosis in a fluoridated community. $J$ Dent Res 1988; 67(12): 1488-92.

129. Paiva SM, Lima YBO, Cury J.A. Fluoride intake by Brazilian children from two communities with fluoride water. Community Dent Oral Epidemiol 2003; 31: 184-91.

130. Pang DTY, Phillips CL, Bawden JW. Fluoride intake from beverage consumption in a sample of North Carolina children. J Dent Res 1992; 71(7): 1382-8.

131. Pendrys DG. The Fluorosis Risk Index: a method for investigatihg risk factors. J Public Health Dent 1990; 50(5): 291-8.

132. Pendrys DG. Analytical studies of enamel fluorosis: methodological considerations. Epidemiol Rev 1999; 21(2): 233-42. 
133. Pendrys DG, Katz RV. Risk factors for enamel fluorosis in optimally fluoridated children born after the US manufactures' decision to reduce the fluoride concentration of infant formula. Am J Epidemiol 1998; 148(10): 808-15.

134. Pendrys DG, Katz RV, Morse DE. Risk factors for enamel fluorosis in a fluoridated population. Am J Epidemiol 1994; 140(5): 461-71.

135. Pendrys DG, Katz RV, Morse DE. Risk factors for enamel fluorosis in a nonfluoridated population. Am J Epidemiol 1996; 143(8): 808-15.

136. Pendrys DG; Morse DE. Use of fluoride supplementation by children living in fluoridated communities. ASDC J Dent Child 1990; 57(5): 3437.

137. Pereira MC. Epidemiologia - Teoria e prática. Rio de Janeiro: Guanabara-Koogan; 1995.

138. Pereira AC. Comparação entre três índices de fluorose dentária na dentição permanente, observados em escolares de 12 a 14 anos de idade, residentes em áreas com diferentes concentrações de flúor nas águas de consumo. São Paulo; 1996. [Tese de Doutorado Faculdade de Saúde Pública da USP].

139. Piovesan A, Temporini ER. Pesquisa exploratória: procedimento metodológico para o estudo de fatores humanos no campo da saúde pública. Rev Saúde Pública 1995; 29(4): 318-25.

140. Pritchard DJ. Plasticity in early development. In: Mascie-Taylor CGN, Bogin B. Human. Human variability and plasticity. Cambridge: University Press, 1995. p.18-43.

141. Rezende J. Obstetrícia. Rio de Janeiro: Guanabara Koogan, 1974.

142. Ribeirão Pires. Na construção da sustentabilidade - Fórum da cidade. 2001; (ago). [Publicação local].

143. Ribeirão Pires. Prefeitura Municipal. Agenda 21 - A cidade, o meio ambiente e o homem. 2003. [Publicação local].

144. Ribeirão Pires. Secretaria de Desenvolvimento Sustentado. Sumário de dados 1997-98. A sua cidade, 1999; 2 (jun). 
145. Ribeiro DM. Suplementos fluorados no Município de São Paulo: avaliação da prática clínica de prescritores, das recomendações de formuladores de políticas públicas de saúde e de entidades profissionais. São Paulo; 2004. [Tese de Doutorado - Faculdade de Saúde Pública da USP].

146. Ribeiro H. Flúor - Análise de teor em água fervida. RGO 1992; 40(1): 59-61.

147. Riordan PJ. Fluoride supplements in caries prevention: a literature review and proposal for a new dosage schedule. J Public Health Dent 1993; 53(3): 174-89.

148. Ripa LW. A critique of topical fluoride methods (dentifrices, mouthrinses, operator-, and self-applied gels) in a era of decreased caries and increased fluorosis prevalence. J Public Health Dent 1991; 51(1):23-41.

149. Rojas-Sanchez F, Kelly AS, Drake KM, Eckert GJ, Stookey GK, Dunipace AJ. Fluoride intake from foods, beverages and dentifrice by young children in communities with negligibly and optimally fluoridated water: a pilot study. Community Dent Oral Epidemiol 1999; 27: 28897.

150. Roldi CR, Cury JA. Metabolismo do flúor após a ingestão de dentifrícios. RGO 1986; 34(5):425-7.

151. Sampaio FC. Prevalência de cárie e fluorose dentária em cidades da Paraíba com teores residuais de fluoretos na água de abastecimento. CCS 1993; 12: 11-9.

152. Santoro AMCV. Teor de flúor nos chás industrializados no Brasil e seu significado para a saúde bucal. São Paulo; 1997. [Dissertação de Mestrado - Faculdade de Saúde Pública da USP].

153. São Paulo. Secretaria de Estado da Saúde. Resolução SS-13, de 08/01/92. Diário Oficial do Estado, 16/01/1992, 11:1 (Retificação dos anexos). [Trata dos Procedimentos Coletivos da área de Odontologia nos serviços de saúde integrantes do SUS/SP]. 
154. São Paulo. Secretaria de Estado da Saúde. Resolução SS-39, de 16/03/99. Diário Oficial do Estado, 17/03/1999, 50 (seção I):37. [Dispõe sobre as rotinas visando 0 acompanhamento dos Procedimentos Coletivos das Ações Básicas em Odontologia, nos serviços de saúde integrantes do SUS/SP].

155. São Paulo. Secretaria de Estado da Saúde. Resolução SS-164, de 21/12/00. Diário Oficial do Estado, 27/12/2000 e 30/12/2000. [Institui as Recomendações sobre uso de produtos fluorados no âmbito do SUS/SP em função do risco de cárie dentária].

156. Schlesselman JJ. Case control studies - Design, conduct, analysis. New York: Oxford; 1982.

157. Schwarz K. Recent dietary trace element research, exemplified by tin, fluorine and silicon. Fed Proc 1974; 33: 1748-57.

158. Silva PSB, Arcieri RM, Saliba NA. Fluorose sim, percepção talvez. Ciência e Saúde Coletiva 2000, 5(Supl.):553.

159. Simard PL, Lachapelle D, Trahan L, Naccache H, Demers M, Brodeur JM. The ingestion of fluoride dentifrice by young children. $J$ Dent Child 1989, 56(3): 177-81.

160. Sjöegren K, Ekstrand J, Birked D. Effect of water rinsing after toothbrushing on fluoride ingestion and absorption. Caries Res 1994; 28: 455-9.

161. Skotowski MC, Hunt RJ, Levy SM. Risk factors for dental fluorosis in pediatric dental patients. J Public Health Dent 1995; 55(3):154-9.

162. Soevik T, Braekkan OR. Fluoride in Antarctic krill (Euphasia superba) and Atlantic krill (Meganyctiphanes norvegica). J Fish Res Board Can 1979; 36: 1414-16.

163. Spear CS, Savisky LA. A study of children's taste and visual preferences in dentifrices. ASDC J Dent Child 1991; 58(4): 300-2.

164. Stookey GK. Review of fluorosis risk of self-applied topical fluorides: dentifrices, mouthrinses and gels. Community Dent Oral Epidemiol 1994; 22(3): 181-6. 
165. Szpunar SM, Burt BA. Dental caries, fluorosis and fluoride exposure in Michigan schoolchildren. J Dent Res 1988; 67(5): 802-6.

166. Tennakone K, Wickramanayake S. Aluminium leaching from cooking utensils. Nature 1987; 325: 6101.

167. Thylstrup A. Distribution of dental fluorosis in the primary dentition. Community Dent Oral Epidemiol 1978; 6: 329-37.

168. Thylstrup A, Fejerskov O. Clinical appearance of dental fluorosis in permanent teeth in relation to histologic changes. Community Dent Oral Epidemiol 1978; 6: 315-28.

169. Tomita NE, Panighel CPMA, Narvai PC, Lopes ES. Implicações da vigilância à saúde sobre a ocorrência de fluorose dental. Rev $A B O$ Nac 1995; 3(5): 318-23.

170. Toumba KJ, Curzon MEJ. The fluoride content of bottled drinking waters. Br Dent J 1994; 176: 266-8.

171. Turner SD, Chan JT, Li E. Impact of imported beverages on fluoridated and non fluoridated communities. Gen Dent 1998; 46(2): 190-3.

172. Uchôa HW, Saliba NA. Prevalência de fluorose dental na cidade de Pereira Barreto. Bol Serv Odont Sanit 1970; 6(3):11-6.

173. [UMESP] Universidade Metodista de São Paulo. Prevalência de fluorose dentária em escolares no Município de Ribeirão Pires, Estado de São Paulo, Brasil, 2000. São Bernardo do Campo, 2001. [Relatório de pesquisa apresentado à Universidade Metodista de São Paulo e Secretaria Municipal de Saúde do Município de Pibeirão Pires, como conclusão do projeto de pesquisa de monitoria da Disciplina de Odontologia Preventiva e Saúde Pública II, em 2000].

174. [USP-FSP] Universidade de São Paulo. Faculdade de Saúde Pública. Levantamento epidemiológico em saúde bucal: Estado de São Paulo, 1998. São Paulo; 1999. [Relatório apresentado à Secretaria de Estado da Saúde de São Paulo como conclusão do projeto realizado 
em convênio com o Núcleo de Estudos e Pesquisas em Sistemas de Saúde, em 1998].

175. [USP-FSP] Universidade de São Paulo. Faculdade de Saúde Pública. Levantamento epidemiológico de cárie, oclusopatias e fluorose dentária, em crianças de 5 a 15 anos de idade, na região do $A B C D$, SP, Brasil, em 1997. Santo André; 2000. [Relatório apresentado à Secretaria de Estado da Saúde de São Paulo como conclusão do projeto realizado em convênio com o Núcleo de Estudos e Pesquisas em Sistemas de Saúde, em 1997].

176. Viegas AR. Odontologia sanitária - Aspectos preventivos da cárie dentária. Compilação das aulas proferidas no Curso de Especialização em Saúde Pública para cirurgiões-dentistas Faculdade de Saúde Pública da Universidade de São Paulo. São Paulo; 1961.

177. Villa AE, Guerrero S, Icaza G, Villalobos J, Anabalón M. Dental fluorosis in chilean children: evaluation of risk factors. Community Dent Oral Epidemiol 1998; 26: 310-15.

178. Villena RS, Ando T. Técnica transversal na colocação de dentifrícios fluoretados: uma alternativa para crianças de idade pré-escolar. Anais da Sociedade Brasileira de Pesquisas Odontológicas. Águas de São Pedro; 1995. [Divisão Brasileira da Internacional Association for Dental Research, vol. 11].

179. Villena RS, Borges DG, Cury JA. Avaliação da concentração de flúor em água minerais comercializadas no Brasil. Rev Saúde Pública 1996; 30(6): 512-8.

180. Villena RS, Cury JA. Flúor - aplicação sistêmica. In: Correa MSNP (Org.). Odontopediatria na primeira infância. Santos: São Paulo; 1998. p. 291-314.

181. Yoder KM, Mabelya L, Robison VA, Dunipace AJ, Brizendine EJ, Stookey GK. Severe dental fluorosis ina Tanzanian population 
consuming water with negligible fluoride concentration. Community Dent Oral Epidemiol 1998; 26; 282-93.

182. Wacholder S, McLaughlin JK, Silverman DT, Mandel JS. Selection of controls in case-control studies - I. Principles. Am J Epidemiol 1992 ${ }^{\text {a }}$; 135(9): 1019-28.

183. Wacholder S, McLaughlin JK, Silverman DT, Mandel JS. Selection of controls in case-control studies - II. Tipes of controls. Am J Epidemiol 1992 ; 135(9): 1029-41.

184. Wacholder S, McLaughlin JK, Silverman DT, Mandel JS. Selection of controls in case-control studies - III. Design options. Am J Epidemiol 1992 ${ }^{\mathrm{c}}$; 135(9): 1042-50.

185. Wang NJ, Groppen A-M, Ogaard B. Risk factors associated with fluorosis in a non-fluoridated population in Norway. Community Dent Oral Epidemiol 1997; 25: 396-401.

186. Warnakulasuriya KAAS, Balasuriya S, Perera PAJ, Peiris LCL. Determining optimal levels of fluoride in drinking water for hot, dry climates - a case study in Sri Lanka. Community Dent Oral Epidemiol 1992; 20: 364-7.

187. Wei SH, Kanellis MJ. Fluoride retention after sodium fluoride mouthrinsing by preschool children. J Am Dent Assoc 1983; 106: 6269.

188. Wenzel A, Thylstrup A. Dental fluorosis and localized enamel opacities in fluoride and nonfluoride Danish communities. Caries Res 1982; 16: 340-8.

189. Willett W. Recall of remote diet. In: Willet W. Nutricional epidemiology. $2^{\text {th }}$ ed. New York: Oxford University Press. 1988; p. 148-56.

190. Winkle SV, Levy SM, Kiritsy MC, Heilman JR, Wefel JS, Marshall T. Water and formula fluoride concentrations: significance for infants fed formula. Pediatric Dent 1995; 17(4): 305-10. 
191. Woolfolk MW, Faja BW, Bagramian RA. Relation of sources of systemic fluoride to prevalence of dental fluorosis. J Public Health Dent 1989; 49(2): 78-82.

192. [WHO] World Health Organization. Fluorine and fluorides. Geneva: WHO, 1984 (Environmental Health Criteria, 36).

193. [WHO] World Health Organization. Oral health surveys: basic methods. $3^{\text {th }}$ ed. Geneva: 1987.

194. [WHO] World Health Organization. Oral health surveys: basic methods. $4^{\text {th }}$ ed. Geneva: 1997. 


\section{ANEXOS}

